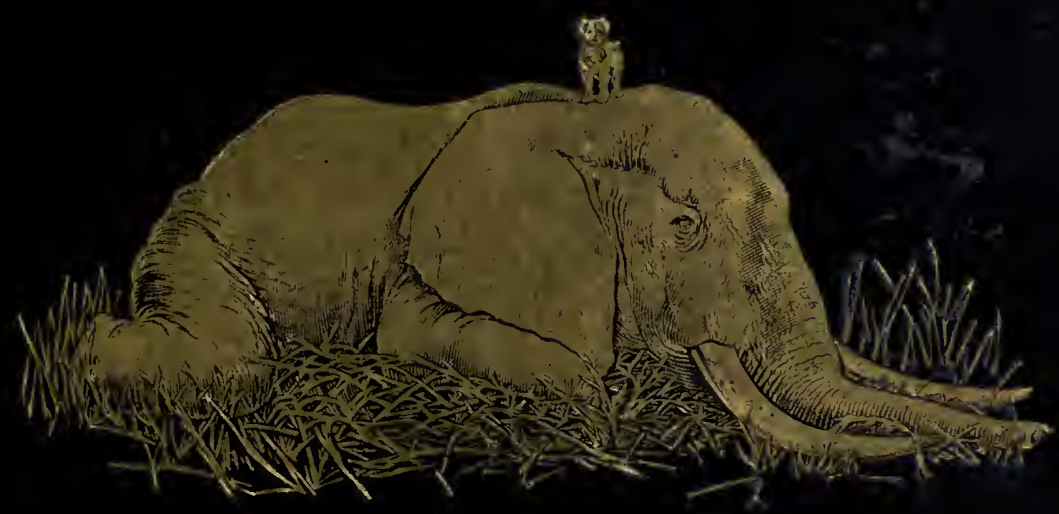




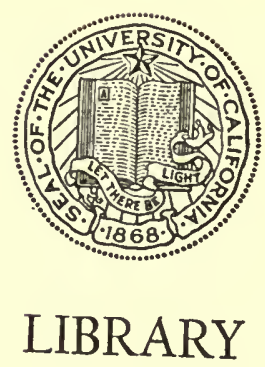

THE UNIVERSITY OF CALIFORNIA SANTA BARBARA From the collection of ELSPETH HUXLEY 
98

E.d. Crant. from N.N. duly 1922 
Digitized by the Internet Archive in 2007 with funding from Microsoft Corporation 


\section{THE ADVENTURES}

\section{OF AN ELEPHANT HUNTER}




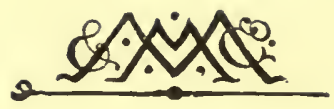

MACMILLAN AND CO, LIMITED LONDON - BOMBAY - CALCUTTA MELBOURNE

THE MACMILLAN COMPANY NEW YORK - BOSTON - CHICAGO DALLAS . SAN FRANCISCO

THE MACMILLAN CO. OF CANADA, LITD. TORONTO 


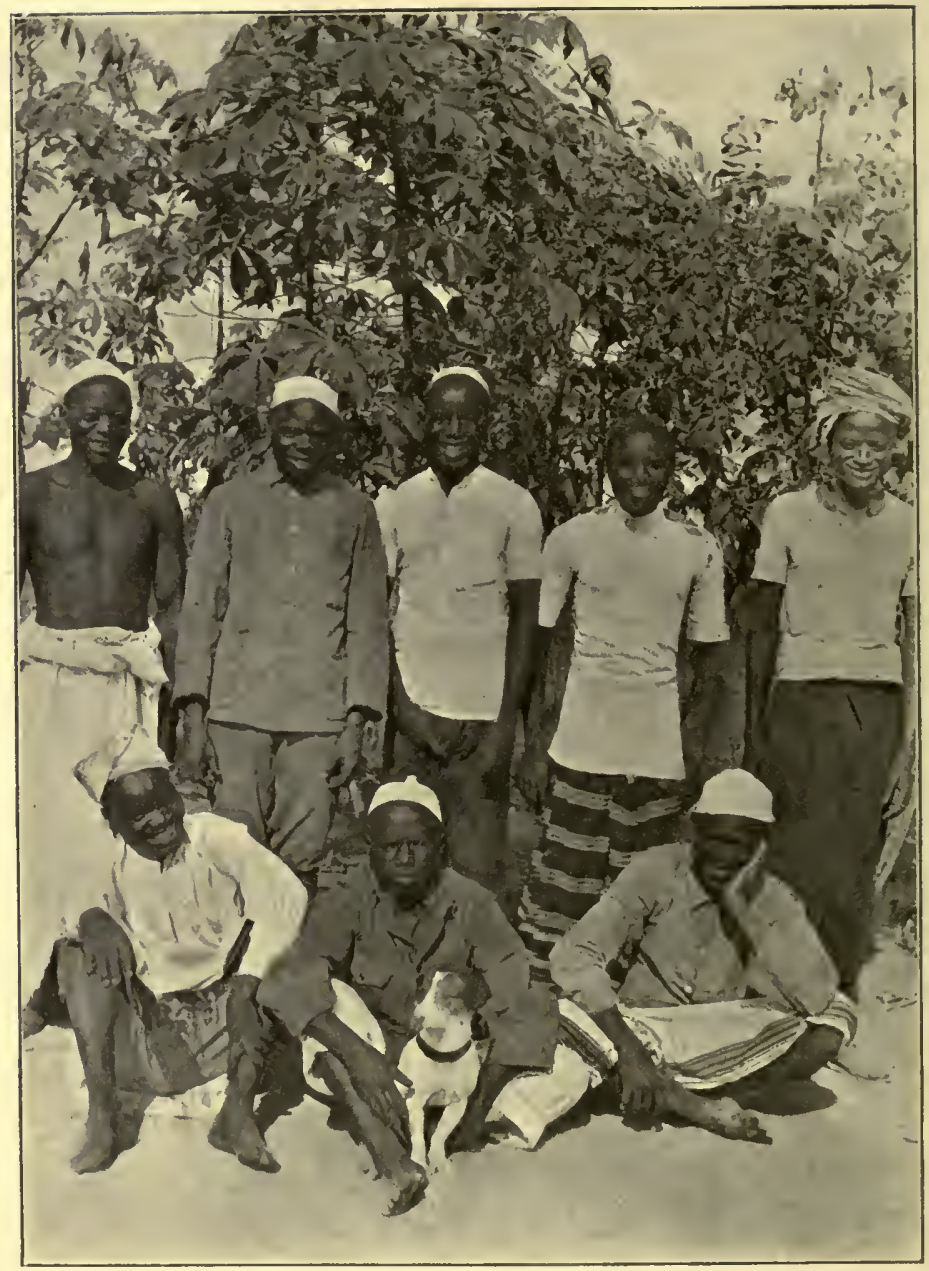

TRACKERS AND PRIVATE SERVANTS. 


\section{THE ADVENTURES OF $\mathrm{AN}$}

\section{ELEPHANT HUNTER}

JAMES SUTHERLAND

WITH ILLUSTRATIONS

MACMILLAN AND CO., LIMITED ST. MARTIN'S STREET, LONDON I 9 I 2 


\section{COPYRIGHT}

Richard Clay and Sons, Jimited, BRUNSWICK STREET, STAMFORD STREET, S.E., AXD BUNGAY, SUFFOLK.

First Edition, Octolir, rgr2.

Reprinted, Nosember, Iэr2. 


\section{PREFACE}

Some two or three years ago, a friend of mine, to whom I had been narrating some of my experiences, warmly urged me to write a book. Knowing that works on big game hunting and tales of adventure were innumerable, and having little time after the arduous labour of the chase to devote to literary pursuits, I, at first, viewed the project with some hesitancy. The idea, once conceived, however, began to mature, and having kept an unbroken diary for the last sixteen years, I felt (apart from any hope of the result some day appearing before the public) that the setting forth of my rough notes in a more finished form would be an excellent method of indulging in the pleasures of recollection, and of calling up before my mind's eye the scenes and people I love so well. If the perusal of my narrative whiles away one dull moment from the reader's life, I shall feel all the more convinced that the time I have spent thereon has not been wasted.

I have intentionally divided up my matter into. 
distinct episodes, choosing from my experiences only those which I feel will interest even the ordinary reader who knows little of, and cares less for, the technicalities of big game hunting. For, apart from the number of admirably written books dealing voluminously with the above sport, I feel that a detailed and consecutive account of even a hunter's career is apt at times to pall, and I have, therefore, striven to eliminate from my humble effort all that is not illuminating in some phase or other.

Before proceeding further, and in the light of some of the personal adventures which follow, a very brief sketch of my life abroad may be of some interest to the reader, and lend a certain cohesion to my stories as far as the question of time is concerned.

I left the Old Country for Cape Town, in the early part of 1896 , with the object of carving out a career for myself. I had no precise knowledge of what that career was to be, I simply experienced an urgent desire to wander-a desire probably inherited from my father, who spent his early manhood golddigging in New Zealand and Australia.

Those early days abroad gave me little that is of any great interest. I moved from Cape Town to Johannesburg (where I spent some time in hospital suffering from the effects of a bullet wound), and 
thence to Mafeking and Matabeleland. Gradually I worked my way up to Beira, from which I did some promiscuous hunting, and afterwards travelled all over Mashonaland. Next, I roved northwards to British Central Africa and roamed the regions about Lake Tanganyika and the Congo, subsequently going to Portuguese East Africa (just ten years ago), and, a couple of years later, to German East Africa, where I have hunted up to the present day.

During these years of wandering, I have done many things to earn a living. I have, at times, engaged in 'nigger bossing'; in recruiting niggers and contracting for the Beira railway; I have been agent for various African trading companies; I have kept native stores; and I have even been a prizefighter. None of these occupations, however, seemed adequately to suit my nature, and I was still uncertain as to what I should undertake as a means of earning a livelihood, when I reached Portuguese East Africa. It was there that I decided to become an elephant hunter, and, practically speaking, I have been on the spoor of the elephant ever since. My adoption of this career was not entirely decided by the question of pecuniary gain, for though I am not poet or philosopher enough to affect a complete indifference to the root of evil, my intense love of sport was a more cogent factor in assisting me to come to such a decision than any love of lucre. 
During the last sixteen years of my life I have only had two short intervals of absence from Africa, and on these occasions I merely paid flying visits to the Old Country, the time spent at home not covering more than three months altogether, while for ten years I have been elephant hunting without intermission, save for a period in $1905^{-6}$, when I fought as a volunteer with the German forces during a native insurrection, receiving for my services a Prussian war decoration from the German Government. During these ten years, I have shot 447 bull elephants (I do not count females), thereby creating a world's record. I do not make this statement in any spirit of boasting: I merely wish to convey to the reader that the stories which follow are not fiction, but facts gleaned from a long and unique experience in one of the most exciting and dangerous sports that the world offers, and jotted down actually as they happened within a day or two of their occurrence. I should like to add, moreover, that I have not gone on safari with a large and well-armed expedition to lessen the risks of my calling, but have always hunted alone, with one or two trusted boys as trackers, and carriers.

To conclude, I may say that I have never regretted the life I have led. It has been a life of weary days and restless nights, of fever, thirst, hunger, toil, and strife; but a life of wild, exhilara- 
ting excitement, of sunlight and air, vast spaces and solitude, of all things which seem to me to be so far removed from the restricting influences of a complex civilization. After so many years of a wild, free life I find it difficult to accommodate myself to the stuffiness and constraint of a modern city: I prefer the pori (forest) to the imprisonment of streets, the twinkling stars to lamps, the sigh of the primeval forest to the tramp of thousands of human feet. After all, this may be the idiosyncrasy of one who has been so long away from civilization that he has lost taste for much that appertains to that civilization, and in this world, well, chacun à son goât.

J. S. 



\section{CONTENTS}

CHAPTER I

THE HUNTER'S LIFE

CHAPTER II

THE FIGHT WITH THE FOUR ............ 16

CHAPTER III

TOUCH AND GO ................... 32

CHAPTER IV

KOM-KOM . . . . . . . . . . . . . . $4 \mathrm{I}$

CHAPTER V

SWASURI AND THE LEOPARD . . . . . . . . . . 57

CHAPTER VI

MAKANYANGA THE PHILOSOPHER . . . . . . . . . 65

CHAPTER VII

MAN-EATING LIONS . . . . . . . . . . . . 69

CHAPTER VIII

VICIOUS ELEPHANTS AND A CANTANKEROUS BUFFALO . . . ${ }^{\circ} 3$ 
CHAPTER IX

THE STRUgGle OF THE titaNS . . . . . . . . . 93

CHAPTER X

UPS ANI DOWNS IN THE MBWEHU BUSH ........ IOO

CHAPTER XI

THE WHITE TRAIL. . . . . . . . . . . . IOg

CHAPTER XII

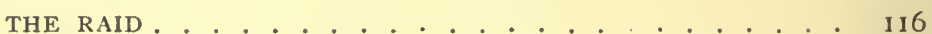

CHAPTER XIII

STIRRING TIMES AT LECUNDI.

CHAPTER XIV

SNAKES

I 38

CHAPTER XV

WHERE A MAN CAN RAISE A THIRST . . . . . I47

CHAPTER XVI

BIG GAME AND BIG GaMe HUNTING. . . . . . . . I57

CHAPTER XVII

MALINGANIRO AND HIS IVORY ........... I76

CHAPTER XVIII

TERRIER $v$ ELEPHANT ............. I 182

CHAPTER XIX

THE TROPICS AND THE CALL........... I. . . . . .

CHAPTER XX

SOIIE NOTES ON THE LIFE GF THE AFRICAN NATIVE . . 194 


\section{CHAPTER XXI}

THE WILD MAN OH THE GOLAMBEPO MOUNTAINS

CHAPTER XXII

HIPPO ANI) LION 212

CHAPTER XXIII

SUPERSTITION AND A SEQUEL . . . . . . . . . 2 I5

CHAPTER XXIV

NERVES AT NTUNKWAE 223

CHAPTER XXV

MAD BUFFALO AND FAITHLESS WIFE . . . . . . 228

CHAPTER XXVI

MY TWO WILD DOGS .

CHAPTER XXVII

THE GENTLE ART OF POISONING . . . . . . . . . 239

CHAPTER XXVIII

TWO LEOPARD STORIES 248

CHAPTER XXIX

MAHOMETAN FAITH AND ELEPHANT MEAT . . . . . . 254

CHAPTER XXX

A FEW thrills at Bangalla River. . . . . . . . 258

CHAPTER XXXI

SOME PECULIAR FOODS . 274

CHAPTER XXXII

THE LORD OF THE RIVER 282 
CHAPTER XXXIII

THREE SLAVE GIRLS ............... 287

CHAPTER XXXIV

A FEW DAYS' HUNTING . . . . . . . . . . . . . 293

CHAPTER XXXV

LOVE AND FAREWELL . . . . . . . . . . . 302

CHAPTER XXXVI

THE HUNTER'S END . . . . . . . . . . . . . 309

INDEX ......................... 321 


\section{LIST OF ILLUSTRATIONS}

Trackers and Private Servants . . . . . Frontispiece PAGE

Large Bull Elephant standing in the dry bed of Mbanangandu

River, afterwards shot by Author . . . . . . . . 3

My last Safari to the Coast . . . . . . . . . . 5

The Author's Camp on the Luwegu River . . . . . . . . 7

A few of my Men ................ . . . I I

Elephant's Tooth . . . . . . . . . . . . . . . 13

Native Axe and Knife used for cutting out Elephant Tusks, etc. 14

The Three Elephants . . . . . . . . . . . . . 19

The Three Elephants . . . . . . . . . . . . . . 23

Fight with Four Elephants (the fourth) . . . . . . . . . 27

The Dead Elephant . . . . . . . . . . . . 36

Four Elephants together . . . . . . . . . . . . 39

Kom-Kom . . . . . . . . . . . . . . . . . 43

Kom-Kom's Tail . . . . . . . . . . . . . . 55

Swasuri .................. . . 6 6

'Njerembo' ....................... . . 84

Elephant called 'Tombacco' . . . . . . . . . . . 85

The Buffalo that tossed Carrier's Boy . . . . . . . . . . 9I

Piece of Broken Tusk . . . . . . . . . . . . . . . 96

The end of the Fighting Elephants . . . . . . . . . . . 97

The Dead Monster . . . . . . . . . . . . . . 104

Three Elephants shot . . . . . . . . . . . . 105

The Third Elephant . . . . . . . . . . . . . . 107

A typical 'Wyao' Headman ... . . . . . . . . . . 117

The First Elephant . . . . . . . . . . . . . . . . I25

One of three Elephants shot one Afternoon . . . . . . . 127

Elephant with some of my Men and their Wives . . . . . I 30

xvii $b$ 
Elephant which charged me and nearly killed my Boy, Usufu Usufu and Malingum . . . . . . . . . . . . 152

The Author and some of his Men . . . . . . . . . 159

Elephant shot whilst sleeping ............ 161

My two Trackers. Simba (on left), Tumbo (on right) . . . . 165

My Tent and Handa with Private Servants . . . . . . . 168

577 Bullet showing ideal Capping; 577 Bullet (in centre) showing ideal Mushrooming; on right, 500 Solid Nickel Covered Bullet . . . . . . . . . . . . . 172

Rhinoceros ................. . . 173

Two Tuskers. The second just discernible in the Background . 183

The Author's little Terrier on the Elephant's Back . . . . . . I 85

My Tracker Simba with three Inswala just shot . . . . . . . 195

Makabuli . . . . . . . . . . . . . . . . 220

Elephant which nearly killed me . . . . . . . . . . . . . 225

Buffalo and the wounded Malingum . . . . . . . . . 229

The Author's Bull Terrier 'Brandy' . . . . . . . . . . . 250

Nyasaland Agri-Horticultural Association, Annual Show . . . $25 \mathrm{I}$

Elephant shot at Bangalla . . . . . . . . . . . 26 I

Three very fine Elephants' Tails, and one absolutely devoid of

Hair . . . . . . . . . . . . . . 264

The Dead Tusker . . . . . . . . . . . . . . . 268

Natives cutting up four Elephants, the Slabs of Meat lying in

the Foreground . . . . . . . . . . . . . . . 275

Sultan Mperembe . . . . . . . . . . . . . . . . . 289

Eland .. . . . . . . . . . . . . . . . 294

Antelope . . . . . . . . . . . . . . . . 295

Hartebeeste . . . . . . . . . . . . . . . . 297

Shot near the Luwegu River . . . . . . . . . . . . 299

Seremani and his Love, Amina, with the Author's Terrier . . 303 
THE ADVENTURES

OF AN ELEPHANT HUNTER 



\title{
THE ADVENTURES OF AN ELEPHANT HUNTER
}

\author{
CHAPTER I \\ THE HUNTER'S LIFE
}

BEFORE dawn I am awakened by the joyful singing of the birds in the forest, and, as I lie, I may occasionally hear the loud snort of a buffalo, the screeching, gossiping chatter of monkeys, or the loud booming woof-woof of the lion, which like an evil dream, seems to lose some of its sinister impressiveness at the approach of day. I am probably about to doze off once more, when my boy brings me a steaming cup of delicious cocoa-not the brick-dust and water concoction so often met with-but a beverage made with boiled milk and flavoured with a suspicion of vanilla. Immediately afterwards, I spring from my camp-bed, fill my lungs with air, and picking up my dumb-bells, go through a 
systematic course of exercise, which keeps every muscle of my body supple and gives me complete mental control over the functions of each. It is to this constant care of my physical being that I ascribe my fitness to-day, after all the vicissitudes of a most strenuous and exacting life under a tropical sun, and to it $I$ also assign a great part of my success as a hunter, for, apart from the temperament suitable for such a calling, the muscular system must be so tuned that it will instantaneously respond to every message of the brain. Upon this co-operation, a hunter's life again and again depends. After exercise a cold tub and a brisk rub down! What a splendid tonic, and what an absolute necessity in the tropics! Next, my boy brings me a lightly brewed cup of tea and some biscuits, and this frugal meal constitutes breakfast.

Our camp is now all astir. My men, consisting of trackers, carriers, cook and private servants -about ten in number-are ready to start, so off we go into the forest with long, easy, springing strides, the blood tingling in our veins with the joy of life. To all intents and purposes, we are absolutely free; there is no vexatious etiquette to be observed; I can burst into a hearty laugh without shocking the ridiculous propriety of a crowded street; I do not require to wear this 
kind of waistcoat or that kind of tie. The morning coat and silk hat I wore on my last brief visit to England, I flung into the sea in sheer exuberance of spirits, when I left Marseilles, glad to be quit of such costly insanity-even a bowler hat is a ludicrous menace to my sense of natural comfort. Alas! though the pori (forest) is

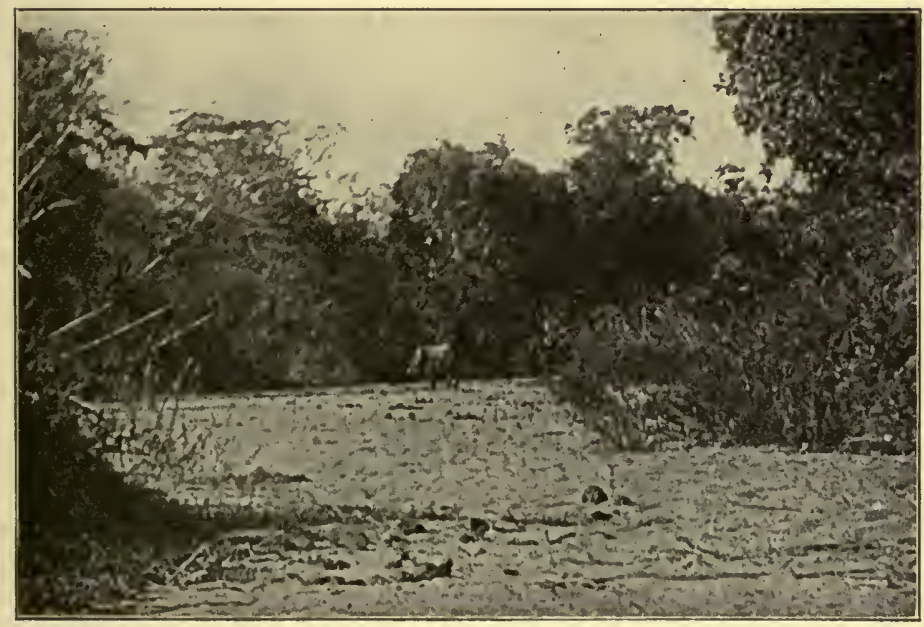

LARGE BULL, ELEPHANT STANDING IN THE DRY BED OF MBAN ANGANDU RIVER, AHTERWARDS SHOT BY AUTHOR.

a place where life is action, it gives a man a great deal of time to think: it focusses his view; it peels from his mind the trivial veneer of civilization and leaves him to brood upon the elemental things which lie at the heart of life. There is also something wistful, tender and infinitely beautiful that forms an undercurrent to the magnificent 
heedlessness of the wild. It calls and calls. And oh, the glorious sunshine-how it steeps right into the very soul! At times you fervently hate it, for you recall baked lips, and a tongue clinging with thirst to the roof of your mouth, but return to England in the winter and you will discover how intimately the visual aspect of a country, bathed in brilliant sunshine, has played upon those hidden strings of the mind that go to form what is called cheerfulness. Ugh! the bleakness of a December day!

'Dembo, bwana!', (Elephant, master!) What a thrill "these words send through a hunter! One of my trackers has come upon the fresh spoor of elephants. We examine their tracks and can tell by the size of the foot-prints whether they have been made by male or female, and by the freshness of the impressions, the approximate time that has elapsed since they passed. The presence of strewn leaves and broken branches and their condition indicate when they fed, and whether they are meandering, or moving steadily ahead for some fixed goal-for elephants know the country quite as intimately as its human inhabitants. They are obliged to know it: on their knowledge of feeding-grounds, water-holes, and dense cover, their lives depend. 


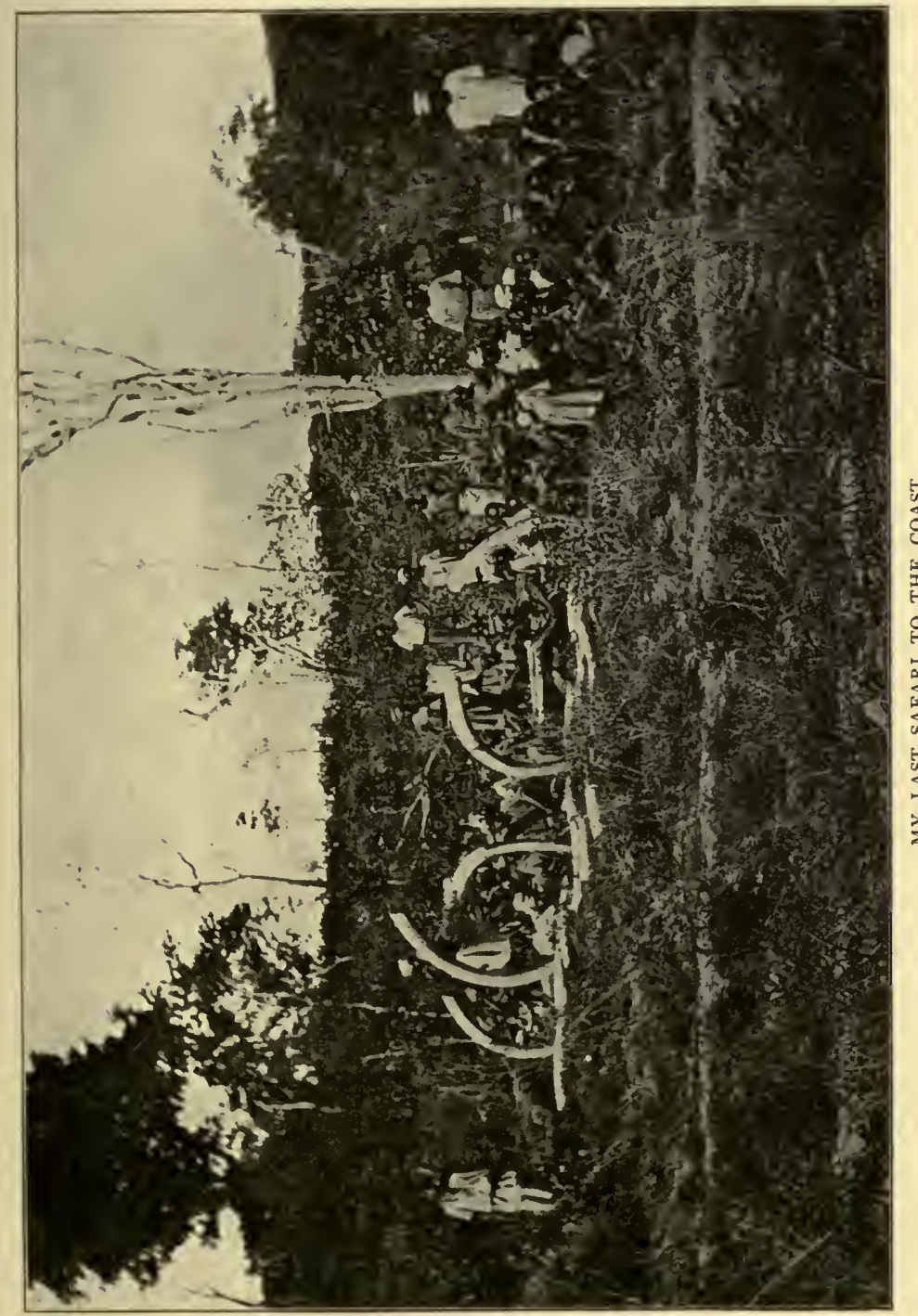


Now that we have discovered fresh spoor, I leave my carriers and boys to follow at a considerable distance behind, while I push ahead with my two trackers in pursuit of the game. These trackers can read the bush as plainly as a civilized man reads his newspaper, and yet, after a lifetime spent in hunting, I can state that they are usually inferior to an adaptable and thoroughly trained white man. Even here, finer brains count. As we trudge along, we suddenly come across fresh droppings, and my tracker, thrusting his foot into them, says they are warm, an announcement which causes me to bubble over with excitement, for I know that we are coming up with our quarry. It now behoves us to advance with the utmost wariness, and I follow my tracker so closely, that he can, if necessary, touch me with his hand. My rifle is held in my grasp, ready to slip to my shoulder in an instant, while my other tracker follows me with my second rifle, so that when I have emptied my first, I have simply to make a half turn and snatch the other from his hands. This action has become almost instinctive with me through years of constant practice, and essentially so, for often one-tenth of a second is in hunting, as in boxing, of vital importance: you may not have the opportunity of saying 
afterwards: 'If only I had been a shade quicker!'

All this while, we have kept in a kind of

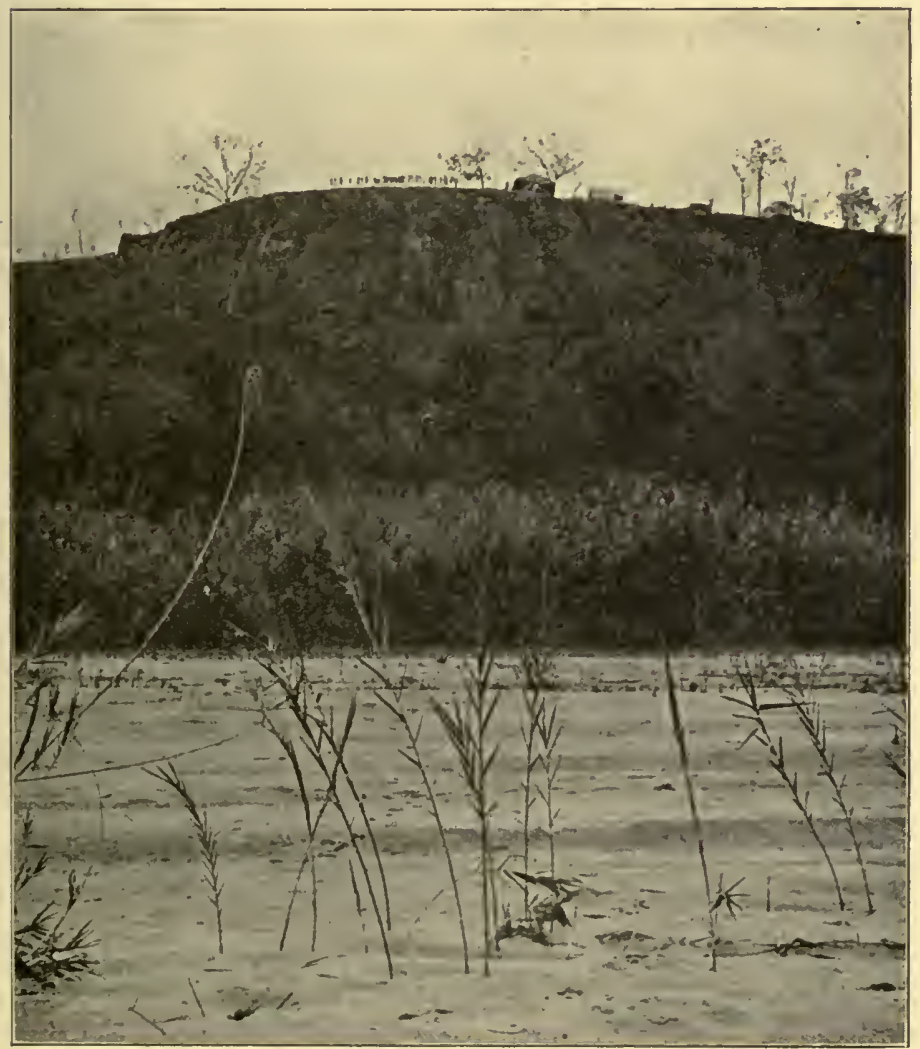

THE AUTHOR'S CAMP ON THE E.UWEGU RIVER.

natural telegraphic communication with my men following in the rear. They track us as we track the elephants, and, here and there, we break a twig or bend the grass for their infor- 
mation, sometimes, even dragging our feet along the ground to give them an unmistakable indication of the direction we have taken. If I wish them to go easy, I tie a piece of handkerchief to a twig; if they are to follow fast, I drop fragments of my handkerchief on the path; if I desire them to halt dead, I lay my handkerchief or tie the grass right across the path.

We are now close to our quarry and move with the utmost caution, lest a hasty movement or a snapping twig warn them of our proximity. If there is no wind, or if the wind blows from them to us, our chances of bagging them are greater than if we were to windward of them, for, in the last case, they may get a whiff of our scent and bolt without giving a chance of a shot, and all our tracking and following up have to be renewed with the same patience and care.

Let us suppose they have not winded us. I manœuvre for a shot, either shifting my own position or waiting for them to move so that they present a favourable view. Temporarily, my mind is absolutely concerned with the business in hand: there is no time to look round and contemplate the beauty of the surrounding vegetation to see whether, in the words of some journalistic hunter, 'the sunlight quivered from a thousand 
leaves, now and then flashing from the gleaming ivory of the Titanic monsters, as they tossed their stupendous heads. A cascade of blue and scarlet flowers tumbles from a creeper near by and lies trampled in my path, etc., etc.' These things may impress the mind subconsciously, but they are utterly irrelevant to the hunter at a critical moment, and such descriptions, however much they may appeal to some minds, I have studiously avoided in my narrative, because to me they seem out of place. The run of my thoughts is generally: "Will he give me a heart shot, or a brain shot? If I wound him will he bolt or will he charge? If he chargeswell, it is the old duel over again, the duel that I have fought successfully up till now. This time my luck may turn. He may finish my careerwell, what of it? I am here to take his lifeall's fair in war. There is no time for "past regrets or future fears." ' If I fail to drop him and he charges, all excitement vanishes. I experience no shadow of fear. During the actual tracking there is always a lively sense of danger -I can hardly call it fear-but now none at all, and I can only describe my mental state at such a moment as a brain working at white heat without a trace of emotion.

Fortune may favour me and enable me to bag 
my quarry without much difficulty. On the other hand, if I merely wound an elephant and he bolts, I make every effort to follow him up and finish him, and I am glad to say that in the majority of cases I accomplish this end. I adopt this procedure apart from the question of obtaining ivory, for in my hunting I have always endeavoured to bear in mind the question of pain. Swift death is comparatively little to any living thing-long drawn out pain is terrible, and when the question of hunting is concerned, the professional is usually too experienced a shot to entail any unnecessary suffering on the animal he hunts, a compliment which, I fear, cannot always be paid to the amateur, or those who scurry through the country with the object of writing a book.

The following up of a wounded elephant, especially if he joins a herd or crosses other spoor and is losing little blood, calls up the finest of skill in tracking. Where the remainder of the herd have been feeding, his spoor may show that he has been standing at rest; his droppings are also usually slightly apart from those of his companions ; and lastly, the impressions of his feet may serve as a means of identifying him from the rest of the herd by showing his method of progression. There is, also, always considerable risk in hunting a - wounded elephant down, for knowing that you 
are on his tracks, he will often make for the densest cover and getting annoyed with your

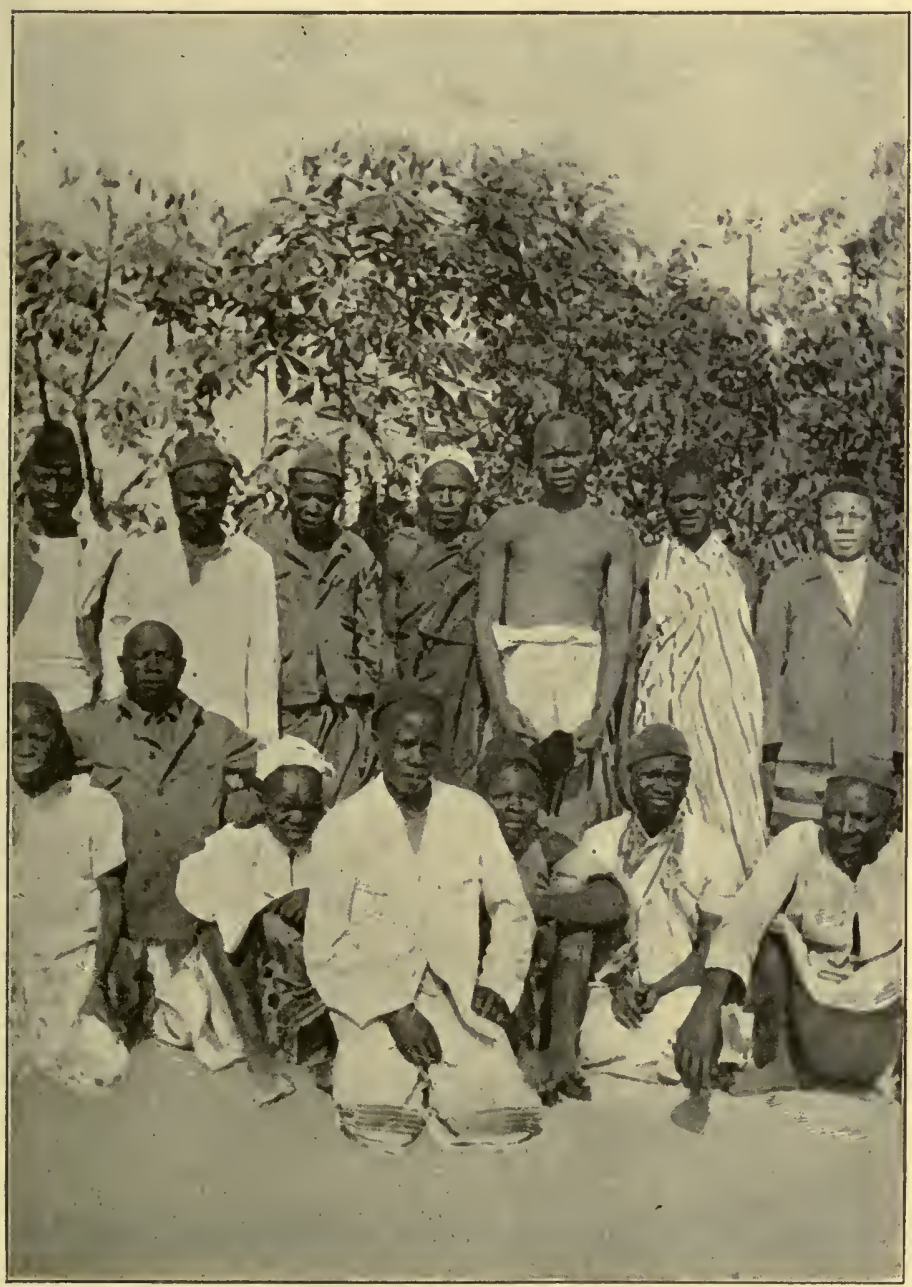

A FEW OF MY MEN.

persistent pursuit, wait patiently for you with the intention of trying conclusions. Aware of this, 
you must be constantly on the alert, for at any moment he may be upon you with one swift dash, sometimes screaming, but usually without uttering a warning sound, and these are the moments which call up every ounce of will, resource, swiftness and coolness of which your nature is capable. If you are deficient in any of these, it would be advisable to bid adieu to your friends before tracking up a wounded elephant.

Often the pursuit of a wounded or shy tusker entails extreme hardship, for, as I have narrated elsewhere, food and water may run out. In case of thirst, it is useful to know that sugar affords considerable relief, and I have found that when my men are feeling the strain of a forced march, there is no restorative to equal a mixture of sugar and cocoa.

Sometimes, if elephants are plentiful, I am from ten days to three weeks or more away from my main camp; and after such a period of absence, I am generally glad to return, for, unless a man wishes to give way under the strain, he must rest and recuperate at intervals. On these prolonged hunts, when we have had a decent bag, I send my carriers back with the ivory to our main camp, and being tired by their arduous work, they stay there, and a fresh relay of men comes out and joins me.

Then, when we have had our fill of sport, and 
nature warns me that I must not tax my energies farther, we start on the return journey to our main camp. Temporarily, the excitement and dangers are over, but a new sense of joy fills the heart, for my men are delighted at the thought of seeing their wives and children or chums again, and I am eager to get back to the comfort of my tent, which, in spite of its simplicity, has for me all the charm that lies hidden in that word-home! My men laugh and chatter ceaselessly as they march, and I have lived so long among them that I know their thoughts as I know my own, and speaking their language as fluently

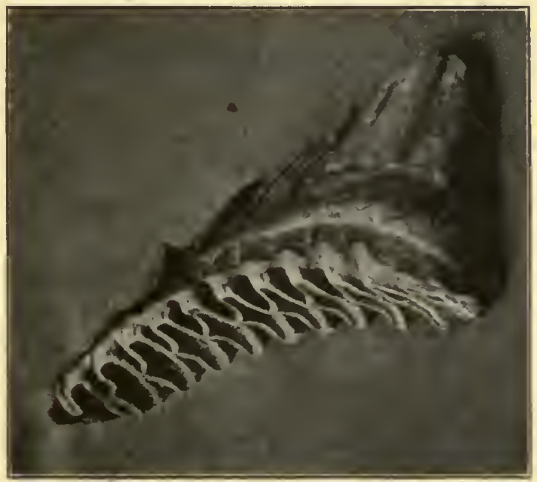

ELEPHANT'S TOOTH.

$13^{\prime \prime}$ in length, $3 \frac{1}{2}$ in width, about 9 lbs. in weight.

as themselves, often join in their jesting. They thoroughly appreciate this, and from them I learn what they are unable, if not unwilling, to communicate to most white men. It is to this intimacy of thought that I ascribe my success in the management of natives, for I know exactly when to be severe and when to be kindly with them.

As we approach camp, we see the smoke of our fires, and no one, who has not lived the life, can 
say what a strange emotion fills the mind at the simple sight, for it is a symbol of all those wider issues that twine about the heart and create that sentiment, which, in the first instance, binds a man to his home and again more widely to his native land.

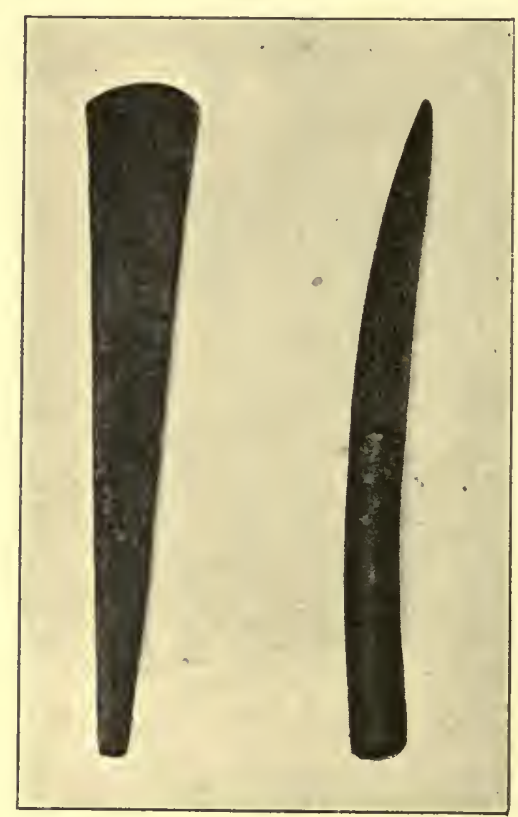

NATIVE AXE AND KNIFE USED FOR CUTTING OUT EIEPHANT TUSKS, ETC. My men's wives and children come out to meet them; chums meet chums; laughter and chatter and affectionate greetings resound on all sides, while I am greeted by my little terrier, who comes jumping up to me, licking my hands and tugging at my trousers in a frenzy of excitement and joy. At last we are home, and I immediately bathe and change my clothes, and all my men, who are wonderfully cleanly, do the same. A nicely cooked meal is the next luxury, and after that, I indulge in a peg or two of whisky and the solace of tobacco. My men make a hilarious night of it. Pombe (native beer) is drunk in large quantities; they dance and sing 
and make love, and above all, there is an incessant talk of the chase. Every little incident is related over and over again, just as a golfer analyses his game to the listener who can command sufficient patience to be bored with the dull details, and from my tent, I can hear how, at such and such a moment, bwana (master) did this or did that, and how the dembo (elephant) behaved under the circumstances.

The 'sentinel stars have already set their watch in the sky,' and now the moon. rising with glorious effulgence, pales the lesser lights of heaven to insignificance and silvers the pori with a mystery that thrills me silently. The shadows are cut sharp and intense. I lie and listen to the ebb of the noisy jovialities; a soft wind flaps in at my tent, and there is something so somnolent in the monotonous sound, that my senses are soon steeped in sound and refreshing sleep.

Give me the life of the pori! I think it would be difficult to find another so full of wild, exhilarating excitement, hair-breadth escapes, and devil-may-care risks, and though the end is usually swift, perhaps that is better than flickering out slowly on a bed of sickness. If anyone has a desire to live, where living is really full-blooded living, let him go and spend some of his time among wild animal life-far away from the insidious comforts and the petty restraints of life in a civilized community. 


\section{CHAPTER II}

\section{THE FIGHT WITH THE FOUR}

'Bwana, dembo!' (Master, elephant!) whispered Simba, my tracker bubbling over with ex citement, as he wakened me.

'Dembo, my boy, wappe?' (Elephant, my boy, where?) I asked, opening my eyes and rising at once to a sitting posture.

'Karebu, bwana! (Near, master!) I have just heard the crash of a falling tree a few hundred yards away.'

Grasping the situation, I listened intently for a few minutes, heard the snap of a breaking branch, and knew that Simba had not erred in his surmise; but as it was only four o'clock in the morning and nothing could be done till dawn, some two hours later, I turned over, pulled my blanket about me and fell soundly asleep again.

During the whole of the previous day we had kept doggedly on the spoor of four big tuskers, 
who had unfortunately got our scent and speedily made off on each occasion that we were about to come up with them. Nightfall had put a close to a most disappointing day's hunt, and worn out, ravenous with hunger and parched with thirst, we had settled down to pass the night at a spot about two hours' journey from the Mbemcuru River, where we might have obtained water, had we had the energy left to cover the intervening distance. We had hoped, moreover, that my four extra men, who were following in our wake with my food-box, and a further supply of water, would have turned up before dark. But in this we had been doomed to disappointment, and, as we had eaten nothing since breakfast and drunk the last of our water at 2 p. m., our frame of mind on retiring had been anything but cheerful.

At first streaks of dawn, we were up and about, and though we felt considerably refreshed by the night's sleep, our hunger and thirst were not a bit abated. In spite of these discomforts-for we were all in excellent physical condition and inured to every hardship-I decided to follow up the elephants we had heard in the early morning hours, hoping to bag one or two by forenoon and then make all haste for the Mbemcuru. Before 
starting, however, I despatched my two private boys to the river to slake their thirst, instructing them to return and double back on the previous day's spoor until they met my four tardy carriers, when they were all to repair to the river and await my arrival. Immediately on their departure, I set out with my two trackers, Simba and Chingondo, the former carrying my light 318 axite rifle, the latter, my double 577 , and we had not gone far afield, when we came across the spoor which we had anticipated, finding to our surprise that the tracks were those of the same four bulls that had so cleverly eluded us the previous day. They had come from the direction of the river, which they had evidently visited for water, and were now making for dense bush, about three hours' journey further on. Fortunately, the wind was favourable, and as they were travelling slowly, smashing, en route, an occasional quaju or wild tamarind tree and feeding at leisure on the juicy, acrid fruit, our prospects of overtaking them, ere they reached their destination, were distinctly good. So we hurried along in pursuit, as fast as necessary precautions permitted, and by ten o'clock managed to get quite close to them, only to experience at the critical moment, a repetition of the previous day's adverse fortune, for they again winded us and bolted.

My second tracker, Chingondo, who carried my 
heavy double 577 , said that he was thoroughly exhausted and could go no further, so taking the weapon myself, I sent him back, instructing him to make for the river by keeping in a straight line, a little to the left of the rising sun. Once more Simba and I trudged wearily along on the

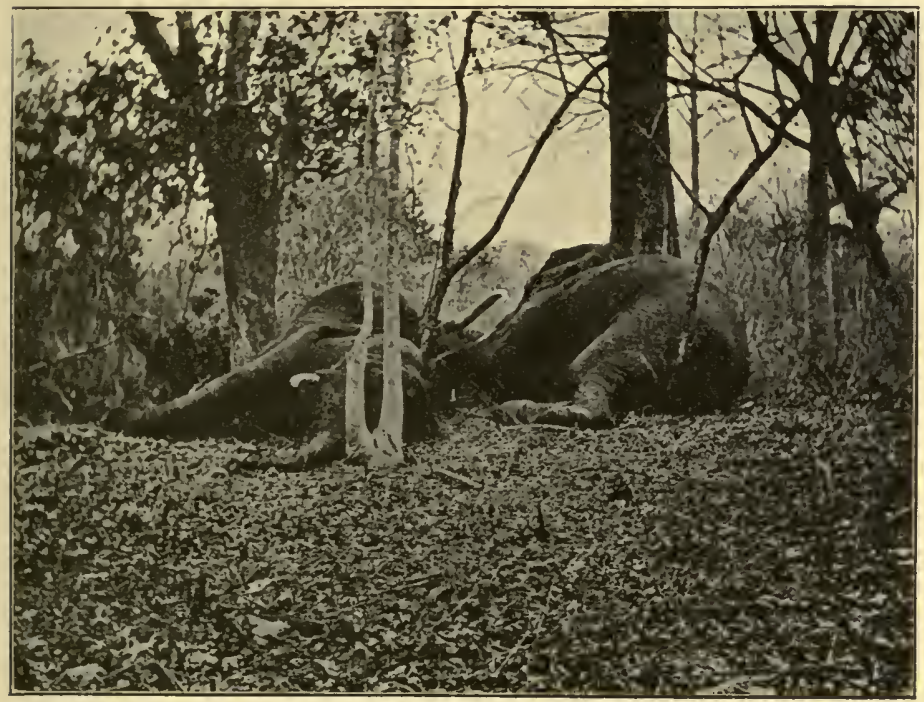

THE THREE ELEPHANTS.

spoor, buoyed up with the hope that the herd would halt on reaching the bush and give us the opportunity for which we longed, but, alas! that hope was to be dashed rudely to the ground! For four interminable hours we followed them across a terrible country, one expanse of dense thicket, long elephant grass, and thorny scrub, 
every now and then encountering a living wall of vegetation through which they had passed with ease, but which had closed in behind their ponderous tread and left a narrow passage along which we could only struggle and crawl with the greatest difficulty. Under such conditions, the utmost caution must be used in tracking, for the slightest noise may at any moment render futile hours of exhausting work. Around us the grass towered twelve to sixteen feet high, narrowing the view to a few feet on any side, and in the confinement of this vigorous, rampant growth the heat was stifling. Thirst, which had, on our starting out, been an acute discomfort, now became almost unbearable, but still we hung tenaciously on to the spoor, and I had just observed with some uneasiness that the currents of air were blowing from all quarters, when we heard an ominous crashing through the bush. For the second time they had winded us and bolted! Words are inadequate to describe the annoyance we experienced, and, too tired, thirsty, and disappointed to speak or think, we flung ourselves down for a well-earned respite. An overwhelming desire to sleep came over me, and, utterly reckless of sunstroke, I was about to indulge in a brief doze, when Simba offered me his snuff-box. I am not in the habit of indulging in snuff, but I must admit 
that that pinch seemed to revive me at once, and give me energy calmly to review the situation. As it was drawing towards evening, a time when all wild animals wend their way to the rivers and pools to quench their thirst, we calculated that our quarry, thoroughly tired by the long chase, would probably be making for water at a leisurely pace. Tightening our belts, and indulging in another pinch of snuff to freshen our jaded senses, we rose and started off once more, resolved to make one final, desperate effort to bag some of the herd, Simba reverently raising his face heavenwards and imploring:- 'Jondie neusimungo nepa sese oui dembo!' (Please, God, give us these elephants.)

After another period of arduous tracking, we discovered that they had left the bush and taken to a comparatively open country, so, breaking into a steady but somewhat feeble trot, we managed, about an hour afterwards, to come up with them, just in time to see them, in single file, slowly entering a patch of long grass. As the sun was rapidly sinking and darkness would be upon us in less than an hour, it was now a case of neck or nothing, so straining every muscle, we dashed after them, excitement and the cool, crisp air of evening pouring new life into our veins. What a devil-may-care 
rush it was-smashing through the long grass, jumping over fallen trees and bent and broken bamboos; now running, doubled in two under a dense canopy of branches, again tearing fullspeed across small open spaces in the forest! All the while, too, we were keenly alive to the possibility that one of the herd might double back for us with a rush; for often a hardpressed elephant will wait absolutely motionless in cover until the hunter is quite near, when he will charge without any warning scream, giving his adversary no time to aim, barely time to drive the bullets in his face in the hope that one will reach his brain or that their impact will make him swerve aside or turn.

All at once, as we careered madly on, the sharp snapping of some bamboos, a few hundred yards ahead, warned us that we were in critical proximity to our quarry, so we slowed down, and, discovering that we were to windward of them, ceased following the spoor and made a détour. Spying a large anthill on our right, we very stealthily made our way towards it and from its summit, saw, to our joy, the four elephants standing about a hundred yards away. One of their number, an enormous bull, with singularly long tusks, was standing a dozen yards behind the others, looking back on the spoor, as if awaiting his pursuers. Down we scrambled at 
once, and, endeavouring to keep to leeward, crept nearer and nearer to him. On this occasion, old Dame Fortune surely favoured us, for when we were about thirty yards from the giant, he suddenly turned and, with his enormous ears outspread at right angles to his head, steadily gazed in our direc-

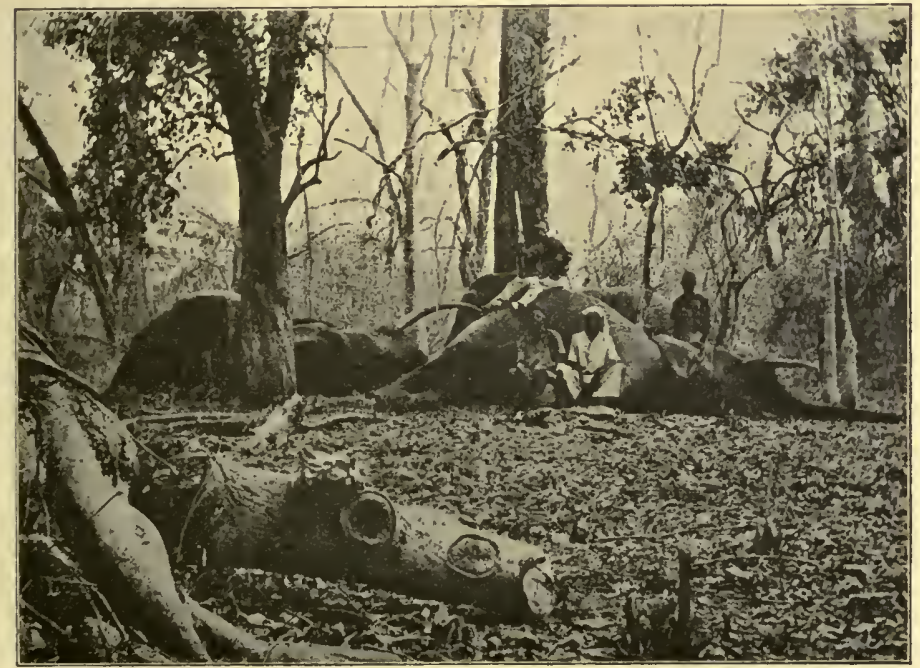

THE THREE ELEPHANTS.

tion. A bullet from my 577 between his eyes, penetrated his brain, instantly dropping him. As the other three, probably curious to know what had befallen their comrade, rushed up to where he lay, I managed to secure a second with a beautiful shot just a little in front of the ear-hole. One of the remaining two, scared by the fusillade, took refuge in flight; the other, apparently mystified by the 
behaviour of his companions, stood hesitant, so, seizing my second rifle from Simba, I placed a bullet in his heart and another in the vertebræ of the neck, bringing him down with a crash beside his fellows. As there was still about half-an-hour's daylight left, I determined to make an effort to secure the fourth, and without waiting to examine our prizes, set out in pursuit of him. Hardly had we got to work on the spoor, when, much to our astonishment, we heard hin crashing through some bamboos in our rear, evidently having circled round to the spot where he had hurriedly parted from his comrades. Unfortunately, he was to lee of us, and getting a whiff of tainted air, plunged madly into a thicket of bamboos, through which we followed him with extreme difficulty. As the light was now failing, and Simba was almost bent double over the spoor, I thought it wise, before proceeding further, to ascertain the nature of the country ahead of us, so, noticing a tree about a hundred yards to our left, I bade Simba go and climb it and return as quickly as possible with his report. He had almost reached the tree in question when, to my horror, I heard a terrific scream and, next moment saw Simba dashing back towards me for dear life with the elephant in hot pursuit. Shouting to him to turn to the left that I might have an unobstructed view of the infuriated animal, who was now only 
about thirty yards behind his intended victim, I took hasty aim and fired, the bullet striking the brute in the side of the head. For an instant he staggered, and then came charging on again! At the same moment, Simba, catching his foot in a creeper, plunged heavily forward on his face, and for one awful second I thought it was all up with my faithful old tracker. In a flash, to my intense relief, he was on his feet again, but, being thoroughly scared, instead of running at an angle, dashed straight on towards me, completely obstructing my view of the animal. Rushing past and slightly to the right of my man, I gave the elephant the contents of my second barrel in the forehead, the terrific impact of the bullet hurling him back on his haunches. The shot, however, struck him too high up to prove fatal, and speedily recovering, he made tracks for the long grass from which he had emerged on seeing my tracker. More determined than ever to bag him-for he had a very fine pair of tusks-I hastily grabbed my light rifle from Simba and gave chase. Ere he had gone far, I managed to place a bullet in the vicinity of his heart, whereupon he instantly turned, and, uttering a succession of short, shrill, screams, bore down upon me. When he was within forty yards of me, I fired in his face-the light was too uncertain for taking careful aim-but 
the small bullet proved absolutely ineffectual, and as he continued his onward career, I drove another through his forehead, hoping to reach his brain and drop him. Still he came on, with head lowered, trunk extended, and blood streaming down his face, and was within fifteen yards of me, when I pulled back the bolt of my rifle to drive another cartridge into the breech, only to discover, to my horror, that the magazine was empty. In the excitement of the hunt, I had completely forgotten that I had already spent two of the five cartridges on the last bull I had shot! There was no time, however, to curse my stupidity, so, fully convinced that this, as far as I was concerned, was the end of all things, I flung my rifle with all my might into the elephant's face and sprang to the left. At the same moment, I heard a terrific report a few inches behind me, and turned to find Simba standing with my heavy rifle in his hands. Seeing my predicament, he had slipped a cartridge into the weapon and fired it at the animal in the very nick of time, the bullet passing through the brute's trunk and crashing into his mouth. Immediately swerving to the right, the elephant collided with a tree, knocking it over like a ninepin, and bursting through the branches, as if they had been so much matchwood, continued his wild career for another fifty yards before coming 


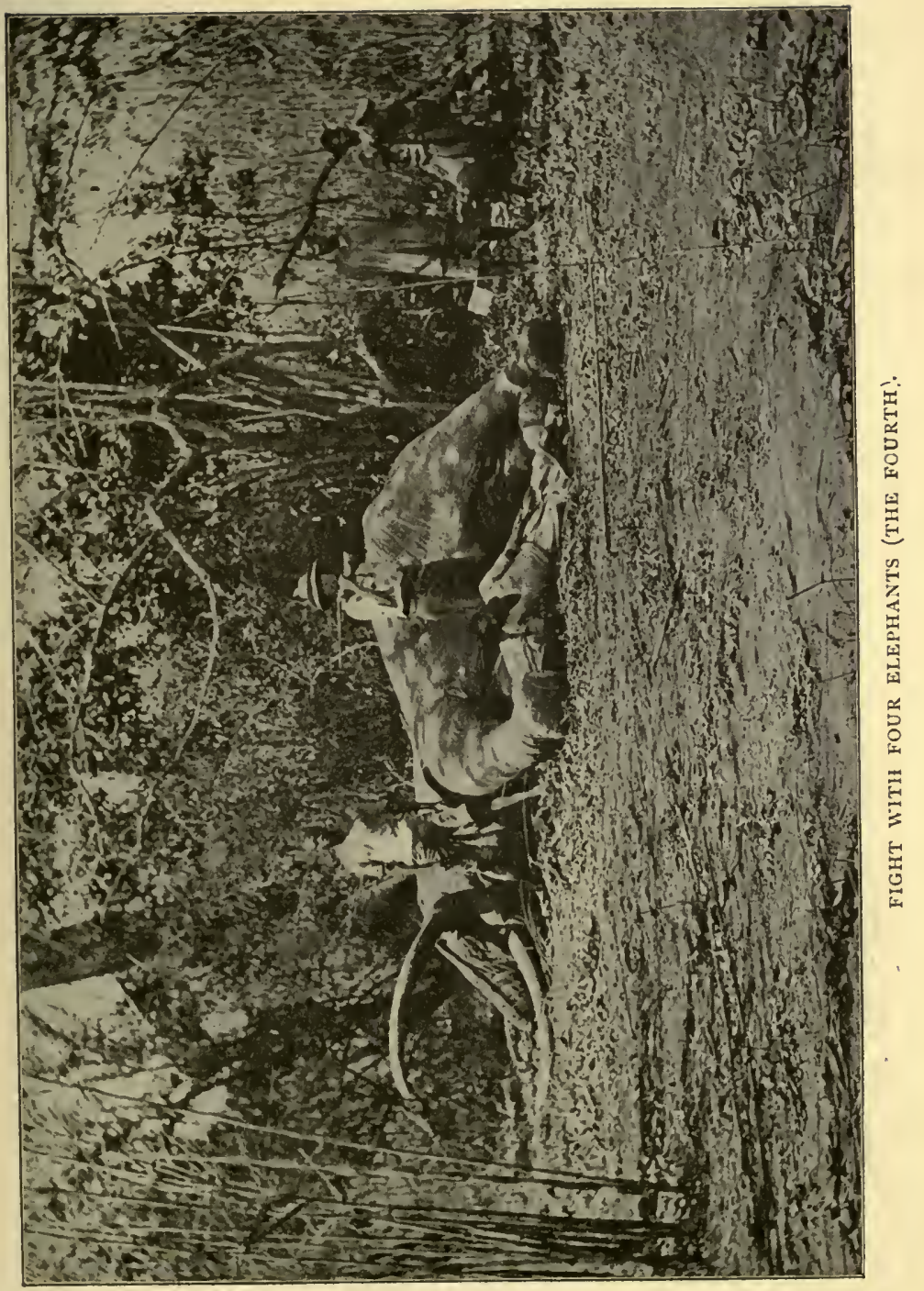


to a standstill. Snatching my heavy rifle from Simba, I slipped a couple of cartridges into it, and, rushing up to the unsteady old warrior, sent a bullet through his heart. He toppled over with a tremendous crash, and after a few gasps, lay still.

Another glorious day's sport over! The thought came to me with some faint touch of regret-alas! life is brief, and its red-letter days so few and far between! Nor had we had too much time to spare, for the sun now set in a magnificent flood of colour, sending long ribbons and streamers of ruddy fire into the deepening blue of the sky, and tingeing the bush with a mystery and charm that I have often wished I could adequately describe. Dragging my weary limbs over to where Simba stood, supporting himself against a convenient tree, I gave his hand a hearty grip-it was by no means the first occasion on which we had faced a life and death encounter together-and being utterly exhausted, flung myself on the ground. My tracker followed suit and for a long while we lay, too tired to think or speak or move. During the tense excitement of the hunt, we had temporarily forgotten our bodily discomforts, but now a swift reaction set in, and we became the prey of a burning, intolerable thirst! No words can depict the awful suffering that the simple want of water. 
can inflict, and poor Simba, unable to bear the cruel pangs any longer, crawled over on hands and knees to where the elephant lay and began to lap up the half-congealed blood which had flowed from the animal's head and gathered in a tiny, shining pool. I myself, half-crazy with the agony, struggled to my feet, pulled a handful of leaves from an adjacent tree, and hoping that the moisture contained in the foliage would cool my parched mouth, was about to chew them. All at once, Simba, having seen my action, rushed up and caught my arm.

'Don't, bwana, don't,' he cried, 'it is the poison tree! Wait a little while and I'll try to get you some roots.'

Somewhat refreshed by his awful draught, he staggered off into the forest, while I again flung myself down and strove calmly to bear the torturing pangs until my tracker returned. I had only lain a few minutes when, to my joy, I heard yell after yell of delight.

'Bwana, nemepona! Bwana, nemepona!' (Master, we are saved! Master, we are saved!) Getting up, I tottered in the direction of the voice and ere long came upon Simba, busy with his knife at the stems of a water-bearing creeper which the natives call ntamba. After he had cut several lengths of about two feet each 
from the rope-like stems, we applied the sections to our baked lips and greedily sucked the deliciously cool, watery juice. Again and again we cut and drank; it seemed as if we should never thoroughly slake our thirst! Our next move was to appease the gnawings of hunger. A glorious moon had now risen and hung low and large, silvering each twig and spray with ghostly light, and making of the jungle a web of vein-like shadows. By its beams we could see to collect fuel, and coming across some dry branches of the mangu tree, set to work to light a fire. Cutting a hole in a flattened piece of the dry branch, Simba inserted a rounded stick of the same wood into the aperture and twirled it rapidly round and round, the resulting friction causing sufficient heat to smoulder a portion of my shirt which I had frayed for the purpose. Gathering some dry leaves and twigs, we soon had a roaring blaze, over which we quickly toasted choice bits of elephant's heart.

A right hearty meal we made, and following up the repast with another long draught of the ntamba creepers, we lazily stretched ourselves beside our fire to dream. of some privileged hunt with Diana and her Nymphs.

Next forenoon, we reached the Mbemcuru River where we found the remainder of our party awaiting 
us. A hot bath and a round meal were soon prepared and enjoyed, and feeling, temporarily at least, none the worse for our experience of the previous night, we returned to where our prizes lay, photographed them and chopped out the ivory.

The first bull shot had magnificent tusks, projecting about six feet out of his head and weighing 102 and 107 lbs., respectively. Those of the second and third scaled 37 and 38 , and 53 and 51 lbs., respectively, while the last animal's beautiful, straight tusks tipped the beam at 75 and $78 \mathrm{lbs}$.

The severe exertion of this hunt brought on a bad attack of malaria which incapacitated me for a few days, but thanks to quinine, tea, and whisky, I felt sufficiently well to resume hunting shortly afterwards. 


\section{CHAPTER III}

TOUCH AND GO

Near the Sultan Leanduka's village on the Luwegu River, in German East Africa, I had, in the Autumn of 1908, a most exciting adventure with an elephant. All day long, we had kept doggedly on the tracks of a herd of five big bulls, at one time forcing our way through dense scrub bristling with thorns, at another warily spooring among belts of giant reeds which marked the driedup courses of tributary streamlets of the Luwegu, itself, at the time, a mere winding expanse of soft, dry sand. Towards evening, we came up with our quarry in an open space, where the sere grass had been levelled by winds and trampled by game, and here I managed, without any notable incident, to account for four of the herd. The fifth, I wounded in the region of the heart as he was bolting full speed across a clearing (where the natives had fired the grass), dotted here and there with a few stunted trees. Immediately on being hit, he pivoted round, 
lowered his enormous head, and screaming with rage, charged straight at me! The celerity and determination with which he came on was not calculated to inspire equanimity, but it was a moment when the necessity for keeping cool was paramount, so, patiently waiting till he was within twenty paces of me, I gave him the contents of the second barrel full in the face. Though the bullet tore through his left eye and emerged on the same side of the head, it utterly failed, to my amazement, to stop or turn him, and, next moment, he was upon me. A vicious blow from his tusk sent me hurtling against my tracker, Simba, who was a few paces away from me on my right, and together we came heavily to earth. Ere I had time to scramble to my feet, the elephant had turned, and seizing me by my khaki shirt underneath the right shoulder, flung me high above him in the air. Though rudely shaken, I was vividly conscious of all that was occurring, and, curiously enough, as I spun through space, the awful conviction flashed through my mind that I had seen the last of my hunting days. I landed on the elephant's back, rolled helplessly off and came with a thud to earth, where I still had sufficient presence of mind to lie absolutely motionless to avoid further attracting his attention. I had fallen on my face and lay with my lower limbs beneath his towering, bulky body, between his fore 
and hind legs, my left foot actually touching the toes of his left hind foot. From that unenviable position, still in full possession of every faculty and keenly alive to every move of the game, I saw him tremulously moving his trunk about, to right, to left, above and below, probably considering what his next move was to be. At this moment, the question flashed through my mind, how will he finish me off? And with irrelevant curiosity, I glanced up to see where my bullet had struck him. I experienced no fear of death, I was not conscious of any panorama of my life passing swiftly over my mind; all excitement had vanished and ny heart was not even beating wildly. I was simply soliloquizing: 'In which way is he going to kill me? Will he kneel on and trample me horribly? Will he drive his tusk right through my body, or will he, by some heaven-sent chance, leave me alone? Whichever way it is, may it be swiftly over and done with!' While these thoughts were passing with peculiar calmness and lucidity through my brain, the elephant deliberately turned round, caught me by the shoulder and flung me violently into the branches of a small tree some fourteen yards away, the impact at once knocking me senseless. On regaining consciousness, a few minutes later, I- found myself lying on the ground with Simba kneeling over me vigorously shaking me 
with one hand, while he pointed excitedly with the other to where the elephant stood sniffing the air, some thirty yards away. I made a desperate effort to rise to my feet, but found, to my intense dismay, that owing to the injuries I had received, this was an impossibility. My back, head, and legs felt as if they had been thoroughly beaten, my left hip was terribly bruised, while my left eye was almost closed up, but, judge of my annoyance, when I discovered that my left thumb was dislocated and my left arm and shoulder so badly strained that I was quite unable to hold my rifle in position. In the mêlée, I had dropped my heavy '577 elephant rifle, so bidding Simba sit down beside me, I managed, with some difficulty, to place my 318 across his shoulder and fire for the elephant's ear; but owing to the shaking I had received, I couldn't, try as I would, keep my rifle steady, and the bullet, instead of hitting him in the desired spot and penetrating his brain, went wide and struck him high up on the right side of the head. At once, he slewed round and advanced towards us as if utterly surprised to find that he had failed to annihilate his enemy. So, telling Simba to hold my rifle barrel firmly, I drove another cartridge into the breech and waited patiently for my bulky opponent. When he was within fourteen or fifteen yards of us, I took aim and making a supreme effort to 
control my breath and steady my hand, pressed the trigger. The bullet struck him right between the eyes, bringing him to his knees as if poleaxed, and as he struggled gamely to rise, I finished him with another shot.

On my men arriving and helping me up to

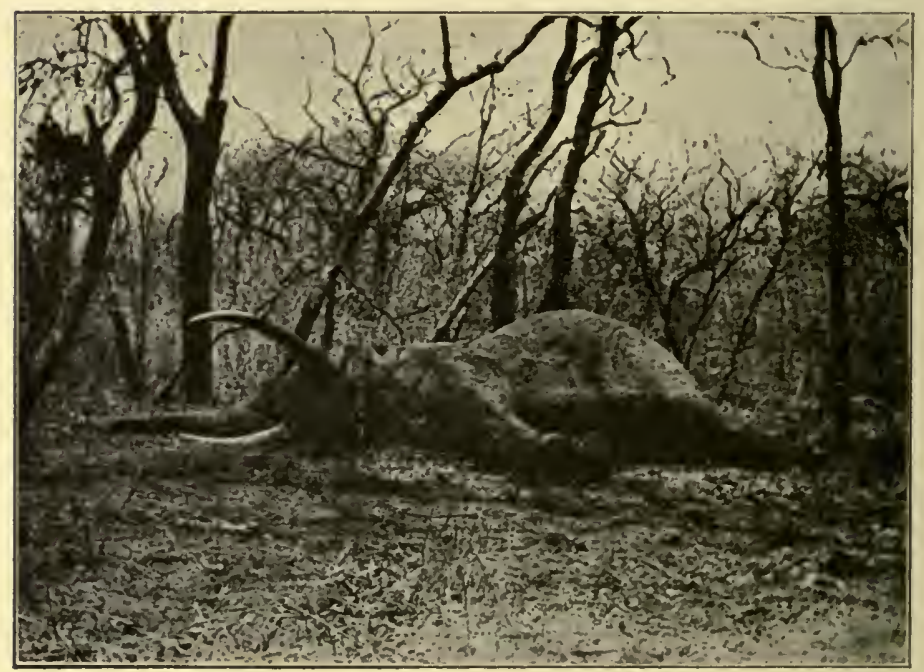

THE DEAD ELEPHANT.

the elephant to make my usual examination of the prize, I was astonished to find that his tail was absolutely devoid of hair. Sometimes, in old elephants, the tails are found greatly denuded of hair, only the stumps of the long, whalebone-like bristles remaining as evidence of youthful, hirsute glory, but, in the specimen of which I speak, no hairs have ever developed and the 
appendage is merely covered with a short, barely perceptible down. I still retain this freak tail as a memento, and shall be delighted to show it to anyone who may be interested.

Early next morning, with the assistance of my boy, Tumbo, I photographed the elephants, and, setting out in a maschilla, a species of portable hammock, rigged up out of my blankets, I arrived at my camp just as night was falling. Never was return more welcome, and the picture that met my gaze as we approached is still vivid in my mind's eye. The greenish canvas of my tent gave a curious illusion of faint luminescence in the dusk; above it, in the sky, hung the golden sickle of a young moon, and on the horizon, as if tangled in the branches of a tree, there flashed that glorious jewel of the tropical heavensthe Southern Cross. Here and there, about the dark shadows of the huts, burned fires, round which sat or reclined the shapes of men, women, and children, some in silhouette, some lit up by the ruddy flames. The low hum of their conversation, every now and then broken by a hearty laugh or a snatch of crooning song, came to our ears, and, all of a sudden, on becoming aware of our return, a wild commotion, and loud, welcoming shouts. Next moment, a crowd of eager chatterers had surrounded us, and were excitedly 
demanding news of the kill, and why it was that bwana was being borne home in a maschilla.

Liberal applications of an emulsion of whisky and olive oil, of fomentations, supplemented by a course of massage at the hands of my native servants, who are quite experts, soon restored me to my normal condition. Yet, strangely enough, in spite of all these measures and my excellent health, I was obliged to die. Some of the natives of the village adjoining my camp, who had accompanied me on the hunt, on seeing me flung into the tree by the elephant, felt certain that I had been killed, and rushing away from the scene of the fray as fast as their legs could carry them, spread the news as only natives can spread news, especially when it concerns the death of a white man. Gradually, however, the sad story of my demise was discountenanced, and I was slowly restored to life, but to compensate for the loss of dramatic value entailed by this resuscitation, two of my native boys were killed in my stead.

About a month later, a somewhat garbled account of the adventure appeared in the DeutschOstafrikanische-Gazette, a translation of which report I append as an example of how news gets distorted by the fertile imagination of the gossiploving native. 


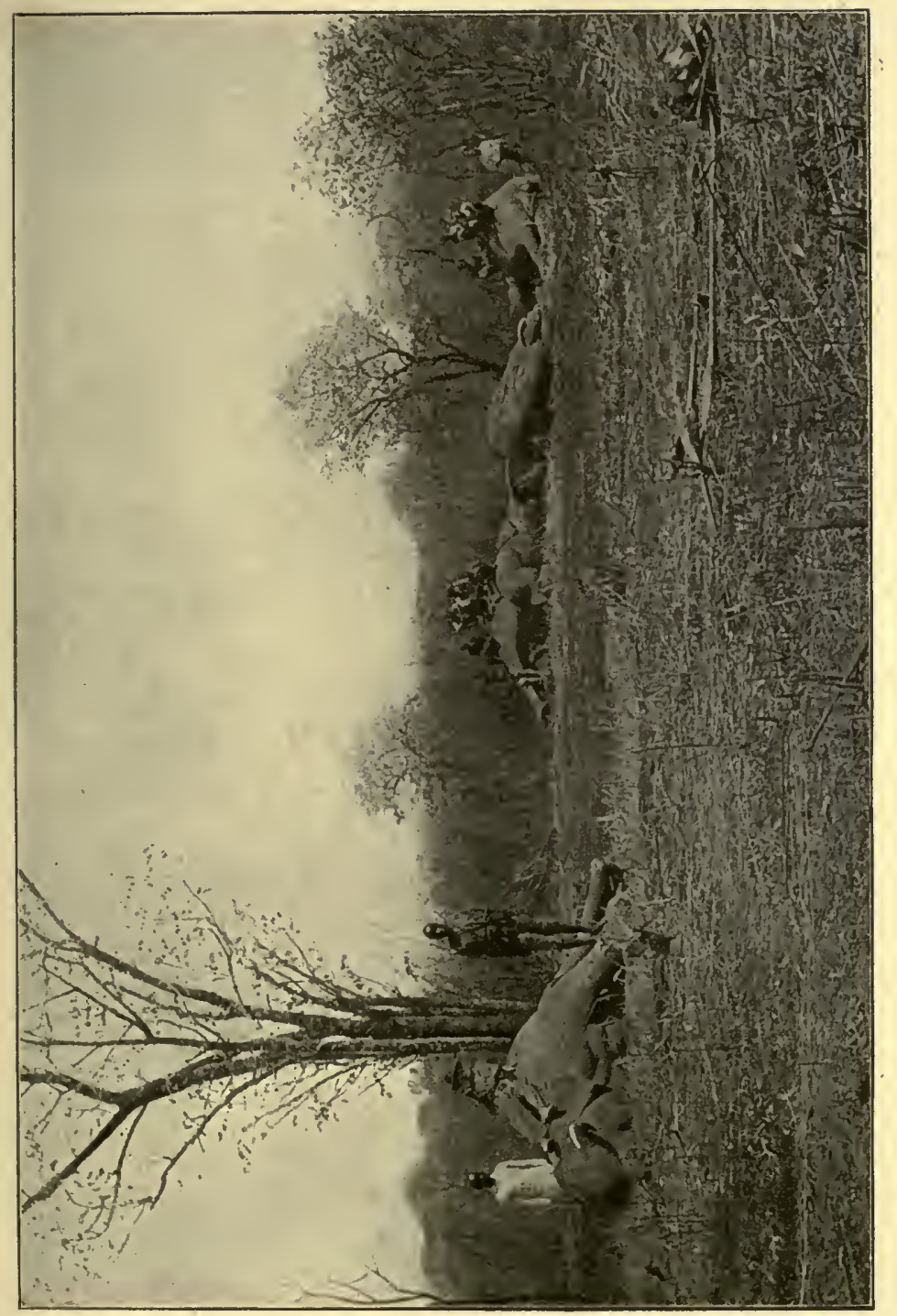

兽 
" 3 rd October, 1908, Lindi. From our correspondent. Sutherland, the elephant hunter, has been seriously injured between Songea and Sassawara. He had the good fortune to bag three elephants. A fourth animal, which he had wounded, pursued him furiously, seized him with his trunk and flung him up on his back. Sutherland, seizing a favourable:opportunity, leaped off again and put another bullet into the enraged beast. Thereupon, the elephant, it seems, crushed some of the hunter's ribs with his trunk and killed two of his native boys. The disaster occurred towards the end of August."

I have often indulged in a hearty laugh over the ludicrous picture called up by the idea of my waiting for a favourable opportunity before leaping off an enraged elephant's back. 


\section{CHAPTER IV}

\section{KOM-KOM}

Some years ago, I was hunting in that wild tract of country that lies between the Lehombero and Luwegu Rivers in German East Africa, and had pitched my camp quite close to Jumbe Iperie's village, a mere cluster of huts buried in the heart of the pori. One day, when I was taking a rest after a particularly arduous period of work, some natives of the village appeared before my tent and piteously begged me to come and kill an elephant that had for years been raiding their shambas or gardens. Nor was theft the only crime they imputed to him; he had, they said, killed several of the villagers, including three native hunters, and all attempts to destroy him or drive him away from the district had proved utterly fruitless. Indeed, so well known was he to them that they had given him the name of Kom-Kom, or, the Mighty One. With that love of mystery 
to which the native mind is prone, they had come to the conclusion that Kom-Kom was the reincarnation of one of their famous chiefs, who in the days gone by had been murdered by the Wangoni. Now his restless spirit had taken up its abode in the form of an elephant and was avenging the wrongs he had suffered during his existence in human shape. Furthermore, they told me that during the day Kom Kom roamed where man seldom trespassed, deep in the heart of the Lerongie jungle and, at night, came forth to plunder their crops and instil terror into their hearts. Even the women were afraid to go and draw water from the stream that flowed near their huts, and so greatly had the reputation of Kom-Kom grown that the inhabitants of Nagoromenia's Kraal, which lay some thirty miles from Iperie's village, lived in perpetual dread of him.

Apart from the question of doing a public service, I was in quest of ivory, and it was immaterial to me whether that ivory was KomKom's or not, so, informing the native messengers that I should make an effort to rid them of the inconsiderate spirit of their former chief, I dismissed them.

Next day, as soon as it was light, we set out for Nagoromenia's Kraal. As we tramped through 


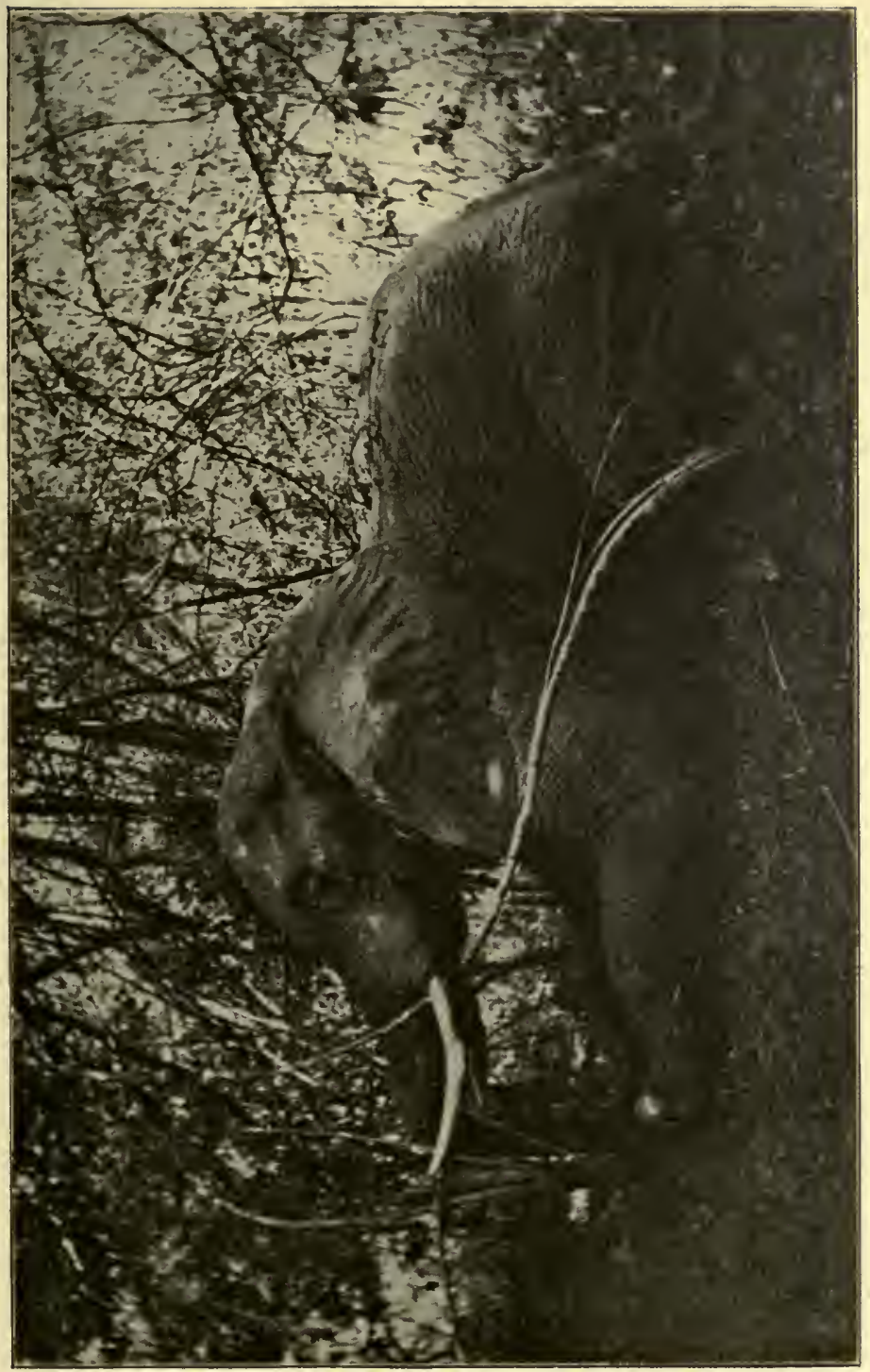


the bush, our clothes, soaked with the heavy dew that distils on the long grass and vegetation during the cool of an African night, clung uncomfortably to our limbs, and it was with a feeling akin to joy that we greeted the sunrise with its cheering warmth.

In the forenoon, we came across the spoor of a herd of elephants and after an exciting chase managed to bag two of them, but the natives of Iperie's village, some of whom had accompanied me, were emphatic in their declaration that neither of these animals was Kom-Kom. Lunch came as a welcome relief to the toil of the chase, and, having rested awhile, we set out for the Lerongie jungle to see if we could come in touch with the Mighty One. Passing through Nagoromenia's Kraal on our way, we reached Iperie's village and there learned that Kom-Kom had visited the natives' matama gardens on the previous night and had committed havoc among the crops. The owners of the shambas were in great distress over the loss, so we decided to pass the night in their village in the hope that the elusive marauder would revisit this convenient feeding ground under cover of darkness and leave us a fresh spoor by which to track him down on the morrow. The night, however, passed uneventfully; not a sound came from the shambas to indicate the presence 
of a feeding elephant, and, as the natives explained, next day, he had probably dreamt that we were in search of him and had wisely decided not to make our acquaintance.

Next morning, at break of day, we started out in quest of Kom-Kom and towards eight o'clock had the good fortune to find his tracks of the previous night. A thrill of excitement ran through our party at the discovery, and it was with an additional stock of eagerness and energy that we began to follow his spoor. By noon, we had considerably lessened the distance which separated us from our quarry; his droppings were comparatively fresh and the condition of the leaves of a nquangwa tree that he had smashed to browse upon clearly indicated that he had only preceded us by a very brief space of time. Consequently, we continued our pursuit with redoubled caution, and were making our way in almost breathless silence when the sudden, sharp snap of a breaking tree warned us that he could not be more than fifty yards ahead. Yet the bush formed so dense a curtain of foliage about us that it was impossible to catch the slightest glimpse of him, and knowing the risks incurred under such conditions I bade my tracker, Simba, who had been carefully spooring in front of me, fall behind. (This order I always give when in close proximity to our quarry.) 
Having taken his place, I was warily advancing, rifle in hand, when, all at once, there came to our ears the sound of an elephant crashing and smashing headlong through the bush. There was no mistaking what had occurred: Kom-Kom, having got a sniff of our tainted air, had instantly made off at a tremendous pace. We followed in hot pursuit and what a dance he led us, through the long jungle grass under the rays of a broiling sun! On all sides the upupu, or itching buffalo bean, twined among the tall grass and every accidental contact with the latter sent the dark green velvety hairs that clothe the bean-pods in showers upon our bare arms, legs, necks, and faces. As there is no method of alleviating the insufferable itching produced by these hairs, except by rubbing the affected parts with wood ashes, an impossible procedure at such a critical juncture, we had simply to endure the irritation in silence and trudge stubbornly on, buoyed up with the knowledge that we were after Kom-Kom, the Mighty One. At length, having thoroughly tired us, he entered a dense patch of entangled vegetation and began to double and redouble on his tracks, using every wile to throw us off the spoor that frequent hunting at the hands of native ivory collectors had taught him. When an elephant begins to 
double and redouble on his tracks, he assuredly means mischief, and feeling that Kom-Kom would prove no exception to this rule, we moved forward with the greatest circumspection. Confident that we were close upon him, we stopped for a few moments and listened with strained ears for any noise that might indicate his whereabouts, but no sound broke the peaceful stillness of the jungle, save the gentle rustle of the breeze among the dense foliage. There now occurred an incident which would have proved a ludicrous anti-climax to the tenseness of the moment, had not the situation been so fraught with danger as to preclude any element of humour. Simba, in spite of a supreme effort to restrain himself, gave vent to a loud sneeze! At once, there was a shrill angry scream and KomKom made a wild, impetuous rush at us from our rear. My trackers sprang nimbly out of his way, and I had barely time to turn, raise my rifle, and fire both barrels into his fas: approaching face!

Fortunately for me, the smashing impact of the bullets sent him swerving aside, and for a few moments he came to a standstill, as if dazed, not more than fifteen yards away. Seeing that I had no time to reload my rifle, Simba, with the precision and coolness that are the result of good nerves and 
long training, instantly handed me my $10.75 \mathrm{~mm}$., but it was well-nigh impossible for me to place a decisive shot, for, from where we stood, the only portion of Kom-Kom visible was his uplifted trunk, ceaselessly moving to and fro above the dense vegetation, apparently sniffing for our scent. Luckily, the Mighty One was to windward of us, and, as if uncertain of our whereabouts, turned and advanced slowly in our direction. Even now, I was quite unable to see him clearly, so judging the probable location of his forehead, I fired once more, but the bullet, instead of stopping or turning him, only served to rouse his anger, and, trumpeting shrilly, he dashed furiously in our direction. Hastily driving another cartridge out of the magazine into the breech, I fired full in his face, but as he came thundering on with lowered head, the bullet crashed into his skull several inches above the right eye. An instant afterwards he was upon us and I was hurled violently to the ground, slightly to the left, and half buried under a mass of broken branches and torn vegetation. It was a miracle that I wasn't trampled! The impetus of Kom-Kom's attack carried him about seven yards beyond where I lay, and at that distance he came to a standstill and began sniffing the air for a whiff of my scent, while I, concealed beneath the heap of débris, could clearly see every movement he made. 
At once, I groped about me for my rifle and discovered, to my intense joy, that it lay undamaged by my side. Eagerly grabbing it, I cautiously opened the bolt to eject the shell and jerked the last cartridge into the breech. At this juncture, Simba and Ntawasie, who had dodged into the bush seeing the elephant almost upon me, and imagining that I must be in a sore predicament, pluckily began yelling in the hope of distracting the animal's attention. The ruse was successful : like a flash, Kom-Kom turned and crashed in their direction. Seizing my opportunity, I quickly raised my rifle and sent the remaining bullet into the vicinity of his lungs, and though not fatal, the shot had a salutary effect, for Kom-Kom immediately gave up the pursuit of my men and tore madly through the bush for some seventy yards to the left. My next move was to extricate myself and regain my feet. Ugh! how sore I felt! When I had fallen, a thick branch had struck me on the right side of my head, severely cutting me under the eye and scrubbing the skin off one side of my nose, while my left elbow, laid bare to the bone, was bleeding profusely and giving me considerable pain. These little mishaps, however, are incidental to the game of hunting and detract little from its joys, so rejoining my two men and exchanging my light for my heavy rifle, I at once decided to resume the pursuit of Kom- 
Kom. As the sun was now low in the heavens and the swiftly closing equatorial night not far distant, I began to view the situation with some uneasiness, for if I failed to bag Kom-Kom before dark, he might clear and his spoor get inextricably mixed up with those of other elephants. Such a contingency might end in our losing him altogether and prove a disheartening conclusion to a most arduous hunt.

The scantiness of the blood-spoor accentuated my fears on this score, for had the second bullet, which had entered his skull above the right eye, merely passed through the upper portion of his forehead without touching his brain, days would probably elapse ere he succumbed to the effects of his wounds.

As we were now to windward of him, a change of tactics was imperative, so instead of following his spoor we decided to make a detour. Here the bush presented a formidable obstacle to our progress, twigs and grass and creepers forming such a bewildering network of growth that we were obliged to crawl on hands and knees, taking care to sever the interlacing stems and branches silently with our knives lest we should give our quarry any warning sound of our advance. Scratched by thorns and cramped by this uncomfortable method of progression, we at length managed to approach within twelve yards 
of Kom-Kom. Though still unable to see him, we could hear the occasional flapping of his enormous ears, and feeling that any attempt at a closer approach would apprise him of our presence, we decided to remain perfectly still for a while and await developments. A few minutes afterwards, we heard the snapping of twigs and branches as he pushed his way for another fifty yards through the thicket, and hurrying to the spot which he had just vacated, we began most cautiously to follow the path which his bulky body had cleared through the matted jungle. Quietly as we had advanced, he must have heard some faint rustle of our movements (unless some treacherous eddy of air had borne him our scent), for, all at once, he turned, came back several yards on his tracks, and stood intensely still. Hoping to get a shot at him at an angle, we stole some distance towards the right, moving the branches aside as gently as possible and taking infinite care not to break any dry twigs underfoot. At this point, the intervening bush was considerably sparser and enabled us to obtain a fairly good view of Kom-Kom who, we found, was standing absolutely motionless, with ears outstretched, intently looking back on the path which he had just made. There was something magnificent and statuesque about his whole pose as he waited there ready to give 
battle should his pursuers come into view. Finding that I could get an unobstructed view of his head from where I stood, I raised my rifle, and carefully judging the angle to his brain, pressed the trigger. The bullet smashed into his skull close to his ear-hole and brought him down with a stupendous crash, his head and tusks being entangled in the tough ropes of the creepers. Kom-Kom the Mighty One was no more! I raised the cry: Socolai! Socolai! (It is finished! It is finished!) and instantly my trackers repeated the exultant yell. It rang deep and sonorous through the silence of the forest and far away it was faintly echoed by my men and some villagers who were following us up: Socolai! Socolai!

Rolled up in our blankets, we passed the night in the forest not far from where Kom-Kom lay dead. From my rough couch, I could see our camp fires throwing mysterious shadows into the luxuriant tropical foilage; through the leaves above my head, shone here and there a bright star. But the beauties of nature appeal but little to a tired man and, ere long, in spite of the discomfort of a cut face and torn elbow, I had slipped into sound slumber.

Early next morning, villagers of both sexes and all ages arrived en masse on the scene, 
and their joy knew no bounds when their eyesight convinced them that Kom-Kom, the source of so many of their troubles, was actually dead. To celebrate the occasion, they brought my men quantities of food, honey, and pombe, or native beer, and runners were hastily despatched to the surrounding villages bearing the glad tidings: 'Kom-Kom is dead! Kom-Kom is dead!'

Alas! a most vexatious fly was to get into the ointment! This particular insect appeared during the morning, in the shape of a sinister-faced old medicine-man, whose superior mind at once discovered that the opinion of the vulgar herd on the subject of Kom-Kom's death had been hopelessly at fault. He announced that he was greatly displeased that I had killed the Mighty One, and declared that, instead of being a matter for rejoicing, it was a serious misfortune, for although Kom-Kom had killed a few villagers and helped himself to the produce of their gardens, this was an insignificant matter in comparison with the infinite good luck he had showered upon them in the shape of food and happy children, and success on their journeys into the forest in quest of beeswax, honey, and rubber. As for Kom-Kom's peccadilloes, well, a certain amount of moral latitude must always be granted to the spirit of a great chieftain! Finding that his audience were not going to allow them- 
selves to be scared from the prospect of a royal feast on elephant meat by any vague mumbo-jumbo concerning the spirit of a departed chieftain, his astute mind took a delightfully ingenious turn. He all at once discovered that he could make a medicine which would set Kom-Kom's spirit to rest on the score of a hearty consumption of its erstwhile earthly home. Some hours afterwards, my boy Tumbo, whom I had brought home with me on this occasion, informed me that the old fellow had begged for a little salt (a scarce commodity in these regions), wherewith to flavour the concoction which was to prove a soothing syrup to Kom-Kom's wounded feelings. Rather curious as to the nature of this elixir, I strolled over to where he was busily engaged in some mysterious operation over a fire. To my surprise, I found that the old humbug, having made the medicine, was now toasting a newly-killed puff-adder on a spit. When he had thoroughly cooked this delicacy, he devoured it and washed it down with copious draughts of an evillooking brew, which, my boy told me, he had prepared by boiling the bark of the mlæravana tree in water and seasoning the mixture with an addition of monkey-nut oil. Next, he anointed himself all over with Kom-Kom's coagulated blood, and while the villagers stood gravely around, solemnly invoked the Mighty One not to be a bad elephant again. 
Either from a profound working acquaintance with the behaviour of spirits, or by message promptly received from the other world, he must have learned that the desired end had been achieved, for, immediately on the conclusion of this ceremony, he made a solid meal on KomKom's toasted heart and energetically assisted his three wives to appropriate as much of the meat as they possibly could, after the manner of the most ordinary of mortals.

For such an exceptionally large elephant, KomKom's tusks were comparatively small, only scaling 65 and 67 lbs. respectively. There is no doubt that he had acquired his cunning at the expense of native

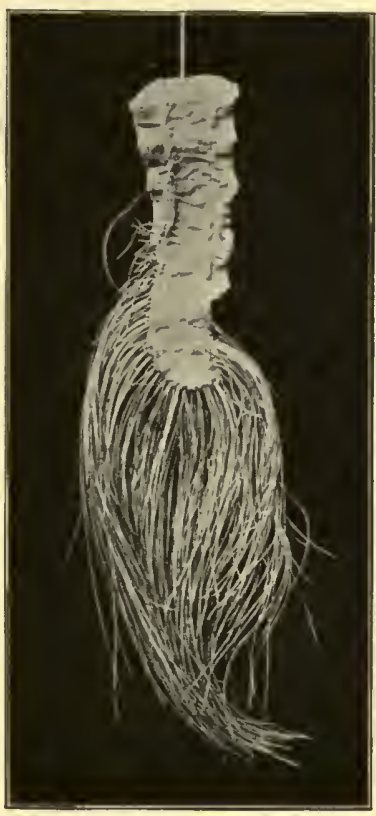

KOM-KOM'S TAIL. elephant hunters, for he bore in evidence of the fact the scars of many old wounds inflicted by their bullets, seventeen of which missiles the natives found when cutting up his tough old carcase. He was also endowed with a characteristic which I have seen in no other elephant 
in all my hunting career; almost all the hairs of his tail were perfectly white. Occasionally, elephants' tails have a few white hairs, but even these cases are extremely rare. I have still in my possession Kom-Kom's singular extremity, and shall always keep it as a memento of a thoroughly enjoyable day's sport. 
One afternoon, in Portuguese East Africa, as we were on our way through the forest to our camp on the Locheringo River and only about two hours distant from our destination, we suddenly heard the sound of excited native voices, not more than a hundred yards away. Our curiosity aroused, we at once turned our steps in the direction of the hubbub, and came upon a score or so of Mataka's men, all armed with muzzle-loading rifles, and, as we learned afterwards, on their way home after raiding a small village on the Rovuma River. They had with them four captives-two boys, a woman, and a girl - whom they were hustling along like cattle, but with a brutality almost inconceivable to the European mind, and so surprised were they at meeting a white man unexpectedly in the heart of the trackless forest, especially in such incriminating circumstances, that they were completely at a loss 
what to do. Immediately on seeing me, the girl, with a courage born of desperation, tore herself free of her captors and, flinging herself on her knees at my feet, tearfully entreated :-

'Bwana, don't let them take me for I am no slave girl, but a free-born Mahometan. Yesterday morning, they seized my mother and me from our village, and are now going to make slaves of us. I'll be your slave if you wish, but I'd far rather die than go with these shenzis (heathens).'

'Be quiet,' roared one of the party of raiders, a big, rough-looking Yao, running up to the terrified girl and seizing her by the arm. Turning to me he exclaimed, 'Bwana, this is my slave,' and with these words, attempted to drag the shrieking woman away. Instantly, I struck him on the jaw with the butt of my rifle, felling him senseless to the ground, and covering their leader with my rifle, gave him to understand that unless he at once dropped his gun I would send a bullet through his brain. Cowed by my threat and determined manner, he quietly laid his weapon on the ground, and turning to my men, inquired of what tribe I was. Upon my men informing him that I was an Englishman, his whole demeanour underwent a complete change; his insolent bearing vanished, and he came up and greeted me in a friendly way, saying, "Yambo, bwana?' (How do you do, master?) Telling his 
men that I was an Englishman and not a Portuguese, he bade them lay down their fire-arms, advance and salute me. One of the number, however, probably deeming it wise to retain his weapon, stood apart, as if unwilling to comply with his leader's command, whereupon Simba, my tracker, ran up to him, seized his rifle, and deftly tripping him, flung him to the ground.

'Now,' said I to the others, 'we'll have a shauri (a palaver),' and turning to the girl, who had by this time risen to her feet, I asked her to tell me exactly what had happened.

'Yesterday morning, at cock-crow,' she related, 'these men raided our small village, consisting of only four huts. My father chanced to be away at the Golambepo Hills on a visit to some of his friends, and the other men and women of the village had gone to drink beer at a neighbouring kraal, several miles away. My mother, these two boys and I were, therefore, alone when these shenzis arrived, and, taking advantage of our defenceless state, they seized us and hurried us away at once. Since yesterday morning, we have been afoot without resting, and I fear my mother will die, for she has been very ill, and to make her hasten along they have beaten her. cruelly. Though we are all free-born Mahometans, they intend to make slaves of us, and the man you have just knocked down says he desires me for his 
wife. My mother and the boys will be sold and I shall be married to a shenzi. Bwana, we are all free-born, and I would rather you should shoot me than let these men take me away.'

I bade the poor girl have no fear on this score and assured her and her fellow-captives that I would see that they got safely back to their homes. Then, turning to Mataka's men, I informed them of my decision, and warned them that if ever I caught them at this nefarious game again I would shoot them down like dogs. Lest they should think I had spoken idle words, I decided to give them an exhibition of the power and effectiveness of a modern rifle, so, choosing a particular tree as target, I fired a few rounds at it, the solid 303 bullets piercing the trunk through and through. Then, as a demonstration of the gun's rapidity of fire, I filled the magazine with ten cartridges and discharged them in quick succession, and from the subsequent expressions on their shining. swarthy faces, I could see that the performance had made a decided impression.

Next morning, the mother of Swasuri (for that was the girl's name) was considerably worse, and quite unable to proceed to her home, so I requested her to stay in my camp until she was well enough to make the journey. This journey she was destined never to accomplish, for, in spite of every 
effort on my part to save her, she died three days afterwards. Swasuri was much affected by this sad occurrence, and on my questioning her as to her future plans, declared that now she had lost her mother, she would prefer to stay in my camp with my men's wives until her father returned from the Golambepo Mountains, for she feared that Mataka's men would pay her native village another visit ere long. The n, when her father came back, she would endeavour to persuade him to leave this part of the country and make his

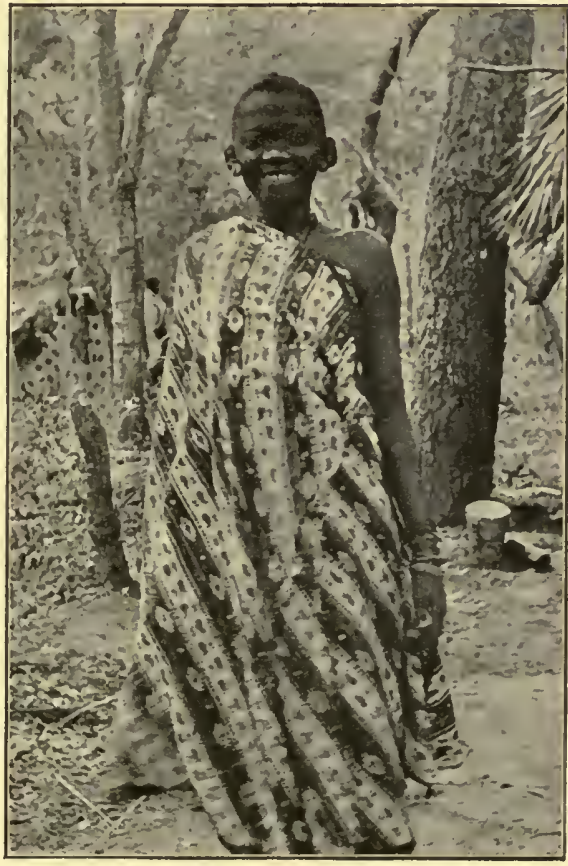

SWASURI. home in German territory, where they would be safe from the further attentions of these inhuman raiders. One of the boys, who expressed a desire to enter my service, I engaged; the other returned safely to his village. 
Some three weeks after this occurrence, I was awakened one morning at sunrise by my servant, Tweegah, who excitedly told me that he feared a leopard had made its way into the fowl-house, for there was a great commotion among the poultry. Picking up my $10.75 \mathrm{~mm}$. magazine rifle, which I always kept loaded in readiness with three cartridges, I dashed out of my tent in my pyjamas and made for the fowl-house, which was close to the banda (a thatched erection serving as a place of shade against the fierce tropical sun). As I approached the latter, Swasuri and one of my men's wives, wondering what was the matter, came out of their hut and followed Tweegah and me with the inquisitiveness peculiar to every woman. My boy was indeed right in his conjecture, for, on reaching the banda, I saw the leopard slinking away, so taking hasty aim, I fired, striking him in the ribs and roiling him over. A moment afterwards, instead of clearing, he rose and faced me, and as he sprang in my direction, I fired. once more, the bullet smashing his jaw-bone, passing through the right side of his mouth, and inflicting a slight flesh-wound in his shoulder. This stopped him, but only for an instant, and barely giving me time to drive my third and last cartridge into the breech, he came straight at me once more. As he sprang I fired and simultaneously jumped aside, 
the bullet on this occasion striking him full in the mouth and tearing its way right through him. At the same time, Swasuri (the others had fled), picking up a spear that was standing against one of the supports of the banda, ran up behind me and pluckily flung it at the brute, unfortunately missing him. As I leaped aside, however, the impetus of the animal's spring carried him past me, and he came down with all his weight upon the poor girl, bringing her with a crash to the ground. Though it was an expiring effort, he managed to drive his claws into her neck and inflict an awful gash right down her breast. Raising my rifle, I brought it down with all my might upon the animal's skull, braining him as he lay on top of the girl, the force of the blow smashing the stock of the rifle to pieces. Then, seizing the leopard by the leg, I dragged him off Swasuri's prostrate and inert form.

The camp was now all excitement; my men and their women, having heard the fusillade, came hurrying to the scene of operations. Without delay I turned my attention to Swasuri, who, I feared, had been killed, but a few moments afterwards, to my great relief, she regained consciousness and opened her eyes. I promptly dressed and disinfected her wounds, and on the com- 
pletion of the task, handed her over to the kindly charge of one of my men's wives. Under the latter's careful nursing Swasuri was soon convalescent, and, ere a month had passed, had completely recovered from her unpleasant little adventure. 


\section{CHAPTER VI}

\section{MAKANYANGA THE PHILOSOPHER}

IN I903, whilst hunting between the Locheringo and Msingie Rivers, in Portuguese Nyassaland, as we had been absent some six weeks from camp-a much longer period than I had anticipated-food for my men and the stock of calico and beads requisite to purchase provisions from the natives ran out, and, owing to the impracticability of arranging a rendezvous on account of my moving about from place to place as the spoor of elephants took me, to send for supplies to my camp in the Golambepc Hills, some five days' journey distant, was out of the question. Elephants, moreover, were plentiful, and as they would probably have moved away from the district ere I could return from a personal visit to camp for provisions, I was at my wits' end to discover a way out of the difficulty. At this juncture, my head tracker, Makanyanga, came to my assistance by experiencing what I can only aptly term a 'brain wave.' I had just shot a 
young male elephant, and Makanyanga suggested that a considerable portion of this meat should be dried, and that he, a couple of native hunters, and some of my carriers should take the meat to the villages at Unangu, and there barter it for food. (In explanation, let me state that most native tribes do not count meat as a staple food, but simply as a species of relish to be eaten with flour foods, such as rice, matama flour, Indian corn flour, etc.)

To this proposal I at once agreed, and tying up the meat in loads, and balancing the burdens on their heads, my tracker and men filed out of camp, bound for Unangu.

In four days' time, the party returned with several packages of food, my tracker informing me that he had bought the supply with the elephant meat he had taken away; but no sooner had they started chatting with my other men and relating their experiences, than the whole company seemed to be convulsed with laughter. Feeling that the joke must be an unusually good one, I asked Makanyanga what was the cause of the excessive merriment.

'Master,' he replied in a somewhat uncertain tone, 'hunger is a great thing, and to assuage the pangs of hunger a man must do a lot. God made men and the last men made were the black men. Besides, all men are fools, only some are greater 
fools than others, while Mahometans are the greatest fools of all. So the first big village we came to, I thought I'd take advantage of the Mahometan's usual stupidity. I told the villagers that your tracker, Kapopo, and I were Mahometans, but that the remainder of the party were not; also, that we had killed three buffaloes and cut their throats according to Moslem rites and were desirous of purchasing food with the flesh. So the idiots said "good," and brought us lots of food in exchange for the so-called buffalo meat, and we, as you see, have brought it here. I will take good care not to visit their village again, for if they ever find out the trick I have played on them, they will most assuredly poison or murder me at the first opportunity."

Upon my remonstrating with him on his duplicity and lecturing him upon the wrong he had inflicted on those unsuspecting Mahometans, he argued: 'Well, master, had I deceived shenzis (that is, heathens), like ourselves, I should certainly feel that I had done wrong, but with Mahometans, no: for they say that we who are not Mahometans are only heathens, and that when we die we all go to Ahellas (Hades), and that they, who are Mahometans, are sure to go to Binguni (Paradise). Now this no man knows, for no human being, to our knowledge, has ever returned from the grave to tell us what to 
expect, and, in any case, we do not believe in the Mahometan creed. So now that they have eaten elephant meat, which, according to their creed, is unclean, if we must go to hell, they must go also. On the other hand, if they go to heaven, we shall go also, for since they have eaten unclean meat, as we do, we both stand on the same footing.'

This was no place for nice argument, even had I been in a position to hold forth on so abstruse a subject. Nor could I let Makanyanga see that I was at all amused, so making some hasty excuse, I quickly retired to the privacy of the bush and gave vent to the laugh which, in order to preserve my dignity, I had been painfully repressing for the last ten minutes. 


\section{CHAPTER VII}

MAN-EATING LIONS

People living in the perfect safety of their homes in a civilized country have no conception of the insecurity that is felt by natives in their kraals in the interior of Africa. The cause of this feeling of insecurity is chiefly the man-eating lion, and no other animal of the forest inspires such terror into the black man's heart. Naturally, there is a reason for this. In those villages, far in the heart of the pori, where the white man is never seen, not hundreds but thousands of natives are annually killed by these monsters.

In nearly all cases, the man-eater is an animal well on in years. He has lost his youthful strength and agility and the capture of wild game for food has become for him a difficult task. He, therefore, adds man to his diet, because the latter is easier to procure; and he appears to be well aware that the natives fear him and are comparatively helpless 
against his attack, for he will, if pressed by hunger, force his way into the native huts at night.

All over East and Central Africa, the idea is firmly imbedded in the native mind that man-eating lions are simply reincarnations of chiefs and medicine men, etc., who prowl about taking vengeance on those who wronged them during their lives in human shape.

Innumerable cases of man-eating lions have come to my personal notice, and perhaps an account of a few of them may prove of interest.

Some years ago, I was hunting in the neighbourhood of the Luhanyando stream, a tributary of the Luwegu, where the country, being mountainous and full of dense bush and grassy ravines, affords excellent cover for lions, who, at the time, were constantly killing natives in these parts.

The details of a particularly sad occurrence that happened in a village in this district are still vividly fresh in my mind, and will perhaps give the reader some idea of the determination, ferocity and daring of the King of Beasts when he has acquired a taste for human flesh.

On the day previous to our arrival, one of the villagers had buried her husband, and she and her daughter, having passed the night in her mother-inlaw's hut, rose at early dawn, as natives usually do, to return to their own dwelling, which was not 
more than a couple of hundred yards distant. 'The homeward path lay through dense grass, and as they sauntered back the girl, who walked a little in advance of her mother, all of a sudden heard a terrified shriek and a fierce growl, and turning round, saw a lion seize her mother by the thigh, fling her to the ground and bite her through the neck. Yelling, 'Simba mama wae!' (Lion, my mother!) she immediately rushed to her hut, only about a score of yards away, and the villagers living close by, hearing her piteous cries, snatched up their spears and quickly appeared on the scene. By this time, the lion had dragged the unfortunate woman into the long grass and could be heard devouring the body some twenty or thirty yards from the path, but to penetrate such a bush after a man-eating lion was an undertaking upon which they would not venture. Knowing that I was encamped near the village, they decided to appeal to me for assistance and without further delay came running to my tent and excitedly explained to me what had actually occurred. Snatching up my double 577 , and taking particular care to insert cartridges with capped, expanding bullets, I hastened to the spot where the native woman had been killed, and holding my rifle in front of me, ready for instant action, I stealthily entered the long grass, my tracker, Simba, armed with a spear, following me as 
if he were my shadow. After making our way for about forty yards through the thicket, we were brought to a standstill by an ominous growl, and, shortly afterwards, heard the long jungle grass rustling as the lion slunk away on our approach. Cautiously following up the spoor, we came to the spot where he had stopped to devour his victim, the grass in the immediate neighbourhood being all trampled down and covered with blood, though, determined not to be cheated of his horrible meal, the brute had dragged the body away with him. By this time, not a sound was to be heard, and, knowing that the animal could not be far off, I advanced with utmost care, ready, should I get a chance, instantly to place a bullet in him. A little further on, we came across the gruesome sight of the woman's half-eaten body and could see that death must have been almost instantaneous, for the animal had bitten her right through the back of the neck. Leaving the remains where they were, we continued our pursuit, moving a few yards at a time, and expecting at any moment to come upon the beast. Suddenly, our progress was arrested by a fierce growl a few yards ahead of us, and, next instant, I caught a fleeting glimpse of the animal slinking away, but it was much too brief to risk a shot. Before advancing further, I told Simba to climb a tree some yards to our right and spy out the 
nature of the country, and, returning a few seconds later, he informed me that about thirty yards ahead of us there was a clearing, where the natives had been preparing the ground for a garden, beyond which space lay an extensive patch of bush. Feeling certain that the lion had left the long grass and made for the bush, we were hastening along, when Simba suddenly whispered: 'Bwana, I heard the grass rustling ahead and imagine that he has just left this cover and is making for the bush on the other side of the clearing. If we hurry, you may be able to get a shot at him before he has.crossed the open space.' Making speedy progress, we emerged from the long grass, just in time to see the brute on the point of entering the thicket on the other side of the open space, so taking hasty aim, I fired, the bullet striking him and rolling him over. In an instant, he was up again, and was about to disappear when I fired my second barrel, unfortunately missing him. Crossing the clearing, we approached to within a score of yards of the spot at which he had vanished into the jungle, there to be met with a growling challenge, and imagining that he was severely wounded, and would before long succumb to the effect of the bullet he had received, I thought it advisable that we should retrace our steps for about thirty yards and await developments. After the lapse of about an hour, I decided to explore the 
bush, fully expecting to find the brute dead, so, listening for some moments and hearing no sounds, we cautiously entered the dense growth and began once more to follow up his spoor, which revealed that he had lost a considerable quantity of blood and appeared to be trailing one of his hind legs. We had not made more than thirty yards of wary progress, when Simba, who was following closely behind me, touched me on the shoulder and pointed to a spot to my left front. Straining my eyes for a few seconds, I could just discern the lion's tawny form, crouching absolutely motionless about twelve yards away, his head between his paws, his eyes gleaming in the shade and gazing steadily in our direction. I raised my rifle quickly to my shoulder, but without giving me time to aim the brute charged me with a vicious snarl! I promptly fired, the bullet striking him on the right side of the head and smashing his shoulder. Unfortunately, with the exception of the first two cartridges that I had used, I had only brought solid bullets with me, and though my third shot knocked him down, he was up again in an instant and came on as quickly as ever. When within five yards of me, I gave him the contents of the second barrel, the bullet smashing through his jaw and missing his heart by a fraction. The impact brought him down and Simba, instantly raising his spear, drove it with all his 
might into the brute's shoulder, while another bullet from my rifle finished him.

On examining the carcase, we found that he was an old and mangy lion, and, as I have mentioned before, it is usually at this period of his existence that the King of Beasts takes to man-eating.

The villagers were overjoyed at the news of the lion's death, and to commemorate the occasion, indulged in a prodigious beer-drink, and fashioned amulets from the animal's bones.

\section{I}

The tragic incidents which follow happened in I 902, on the eastern shores of Lake Nyassa, where some natives, having left their old homes with the intention of settling down anew, had erected temporary grass huts and were tilling their shambas for the coming rains. Arriving on the day following the unhappy affair, I gathered an account of it from some askaris or native police, who had participated in the occurrence.

On the night in question, five of these askaris were sleeping in one hut when, about three o'clock in the morning, one of them was awakened by a low growl and the noise of a sudden crash, which he felt betokened the presence of a man-eating lion. He inmediately roused his comrades, who, picking 
up their rifles, went outside the hut and listened intently for any noise that might confirm their comrade's surmise. A low moan broke the stillness of the night, and discovering that the sound issued from a hut some fifty yards away, in which a woman and her child were sleeping, they crept closer and distinctly heard the sound of bones being crunched inside. Convinced that a lion had broken into the hut and was making a meal of the woman, whom he had killed, they promptly emptied their rifles into the dwelling, trusting that a lucky bullet might find its billet in the animal. For a space, they waited to see if the man-eater would come forth, but as he made no appearance and silence reigned in the hut, they came to the conclusion that he had either been killed or was crouching expectant, ready to spring on the first man who dared venture too close. Deciding to take no risks, they fashioned torches of dry grass and, setting them alight, flung them from a distance on to the roof of the hut, the dry inflammable thatch of which was soon ablaze. Ere the conflagration had died down, the dawn had broken in the east and with the light of day they learned the truth. Going over to the still glowing embers-all that was left of the hut-they discovered the charred remains of a lion, a woman, and a child. Only one bullet had struck the lion, but that one had gone right through his heart 
probably killing him instantly, while the woman's body had received three bullets, though she had probably died long before being hit by them, for her right shoulder and breast had been terribly bitten and chewed. The child's head had been crushed in, evidently by one blow of the beast's paw.

\section{III.}

While hunting in the Sultan Leanduka's country, some years ago, I noticed that the natives always went about together in twos and threes fully armed, and on my asking the reason of this curious behaviour, Leanduka told me that his people were living in terror of man-eating lions, one of which monsters had accounted for no less than fifteen individuals during the rainy season. The beast, he said, never visited the same village on successive nights, but came one night here, next night there, another night several miles away.

One day, as I was returning after an elephant hunt to my camp near this village, I was met, some miles from home, by a native who, in great distress, informed me that on the afternoon of the previous day a lion had killed his brother and his brother's two wives, while they were on their way from one village to another. On returning to camp, I immediately set forth on the tracks of the beasts, but 
though I followed the spoor for two days, I failed, owing to the grassy nature of the country, to come up with them at all, the cunning brutes seeming to know that they were being hunted and making off at once on our approach.

In July, 1905, I had occasion to send a couple of my men from my camp on the banks of the Rovuma River to Songea, about eight days' journey distant, and some thirty miles on their way, they arrived and decided to put up for the night at Gwia's village, where, so the inhabitants informed them, lions had recently accounted for nine lives. They slept by themselves in a hut, in the centre of which they had kindled a large fire, Majemba lying on one side of the fire and Hyiah on the opposite side, nearest the door; and paying heed to the warning they had received on the score of man-eaters, they took particular care before retiring, to secure the door as strongly as possible. About three o'clock in the morning, the door was violently burst in, and before my men exactly knew what had happened, a lion seized Hyiah by the thigh and proceeded to drag him out of the hut. Immediately, Majemba, who had been awakened by the commotion, seized his rifle and fired at the brute, luckily putting a bullet in the region of his heart, whereupon the animal instantly dropped Hyiah and cleared into the surrounding bush. At break of day, the villagers 
discovered the animal's dead body, some seventy yards from the hut, and it proved to be that of a mangy old lioness.

After cleansing Hyiah's thigh with hot water, the natives fashioned a maschilla and carried him into my camp, where I immediately bathed and syringed the poor fellow's wounds with disinfectants to prevent blood-poisoning setting in. These precautions proved effectual, and within six weeks Hyiah was able to get about again.

Two years after this occurrence, I chanced to meet the headman of the village where the events had taken place, and he informed me that his kraal had not been disturbed by lions during the interval; a fact which seems to prove that the lioness shot by Majemba had accounted for the three men and six women that had been carried off previous to the arrival of my men.

When at the Bangalla River, some years ago, after elephants as usual, I heard that lions had killed and devoured a considerable number of natives in the district, and on making particular inquiries of the older men in the neighbourhood, learned from them that within five years lions had accounted for more than thirty people, actually breaking into the huts to seize their victims.

About twelve years ago, while I was on the 
Upper Shire River, in British Central Africa, anoiher instance of a man-eating lion came to my notice I was sitting in my tent, when one of my men, whom I had paid off two days before, came running up in a state of great excitement, shouting 'Incango a mio, incango a mio!' (Lion, my mother, lion, my mother!). On my counselling him to be calm and tell me what was the matter, he informed me that a number of lions, having killed his mother, wife, and two of his children, had taken possession of his home, and though I subsequently found this to be an exaggerated account of the disaster, the matter turned out to be serious enough. Picking up my rifle, I at once set out for his hut, which was about a mile distant, and on arriving there found several natives in a state of great perturbation, gathered about the door of the dwelling. From them I learned that my man's wife, carrying her youngest child on her back, as is the custom with native women even when working, had been grinding flour for the evening meal just outside her hut, while her mother and other child were resting inside, when, all of a sudden, without a warning sound, a lion appeared on the scene and snatched the babe from her mother's back. Dropping the child almost immediately, the brute sprang on the mother, bit her through the neck, and having dragged 
her into the shamba where the matama corn lay cut. began to devour the body. Shortly afterwards, another lion appeared on the scene and joined in the ghastly meal, the whole tragedy being enacted before the eyes of those in the hut, who were too terrified to run or cry for help to the woman's husband who was fishing from the river-bank, not more than a couple of hundred yards away.

When the husband returned to his hut, an awful sight met his eyes; his youngest child, bitten through the skull, lay dead at the door, while in the distance two lions were growling over and gorging themselves on his wife's body. Remembering that I was in the neighbourhood, the distracted fellow, as I have narrated, ran with all haste to my camp and begged me to come to his assistance.

In his absence, some natives, who had heard his terrified yells, at once made their way to his hut and the lions, on seeing them, left their victim's body and vanished into the bush. On reaching the spot, I at once went into the shamba and discovered the horribly mangled remains of the unfortunate woman lying among the matama corn, but as nothing more could be done as far as she was concerned, accompanied by two of my men, I inmediately set out in pursuit of the lions. Though we followed their spoor till sunset, never a glimpse of them did we get, so, returning to the village, I made the natives leave 
the woman's body where we had found it, hoping that under cover of night the brutes would hie them back to finish their meal and give us a chance of avenging the poor creature's death. Making as comfortable a perch as possible in the branches of a convenient tree, rifle in hand, I kept a weary vigil till dawn broke, but, throughout the long tropical night, no lion's shape darkened the expanse of the brightly moonlit shamba.

Strange to relate, the native who had thus lost wife and child in one afternoon was, a few days after his bereavement, himself seized and devoured by a crocodile. 


\section{CHAPTER VIII}

VICIOUS ELEPHANTS AND A CANTANKEROUS BUFFALO

AN elephant seldom makes an unprovoked attack on a human being, but I should like to give two out of several instances of such attacks that have occurred to my own knowledge.

Once, when we were in the neighbourhood of the Lukumbuli stream, one of my men, Njerembo by name, fell in love with a handsome, flashing-eyed beauty, called Asalie, and his affection being reciprocated, preparations were set on foot for their wedding, but, alas, fate had decreed that no such happy event was to take place! A few days before the wedding, the girl and her parents made a journey to a neighbouring village to buy some fowls for the wedding feast, and one can imagine Asalie setting out on this auspicious occasion with all the suppressed excitement that a maid must feel at the approach of such a momentous event in her life. Probably, to this child of nature, with emotions unspoilt by any of the trammelling influences of 
civilization, the world presented itself in the rosiest of hues; her dream of love was marred by no obtrusive thoughts on the material side of marriage; romance was all in all, as it always is to those whose hearts are young. From my know-

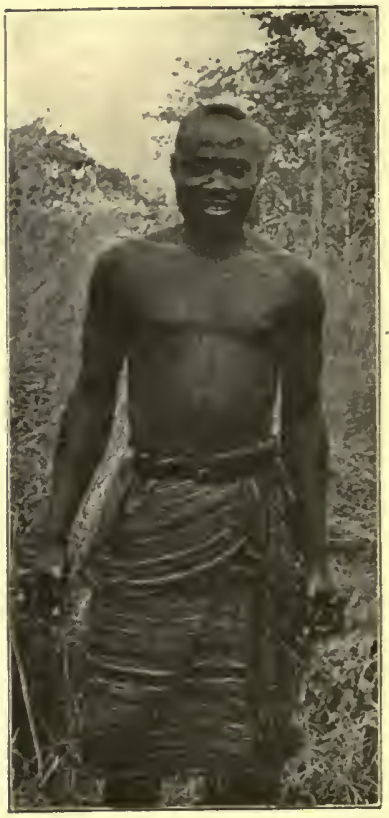

'NJEREMBO.' ledge of the native mind, I can only conjecture thisperhaps my own temperament is partially responsible for the surmise. However that may be, on the journey home, Asalie sauntered along, some distance behind her parents, carrying on her head a little native basket, called a majamanda, containing some of the good things destined for the marriage festivities. All at once, her parents heard a terrified scream, and looking round were horrified to see an elephant rush out of the bush, catch hold of the girl, fling her down and trample her out of recognition. The whole tragedy was enacted in a 'few moments-so swiftly at times does Atropos sever the bright thread of life! Unfortunately, I was unable to avenge poor Asalie's death, for I was 
out hunting at the time and only returned to camp two days after the sad occurrence, when it was too late to follow up the spoor of the murderer, because his traces were completely obliterated by the fresh tracks of other elephants.

The natural light-heartedness of the average

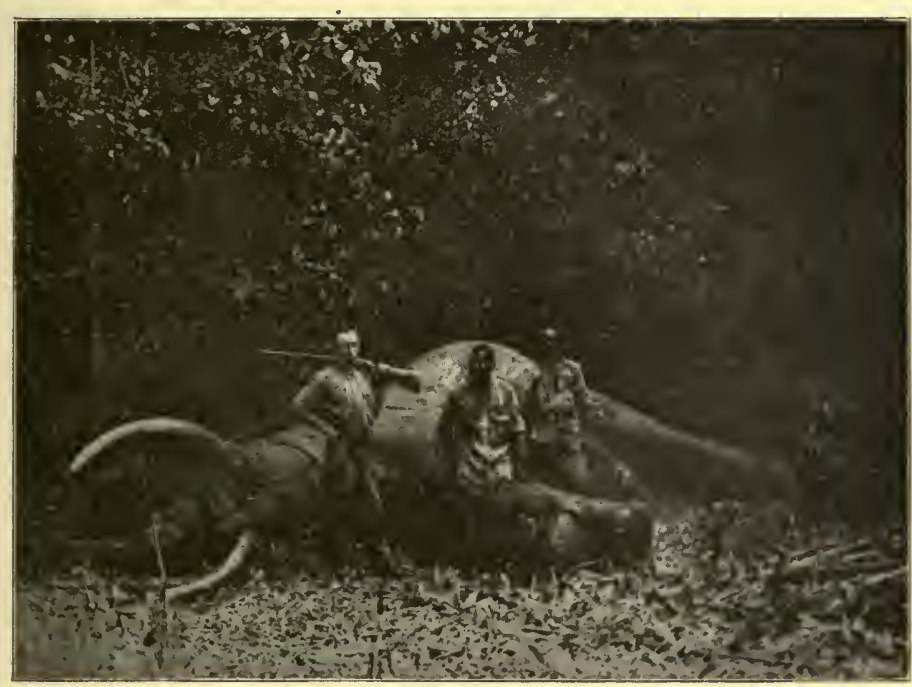

ELEPHANT CALIED 'TOMBACCO.'

African native soon allows him to forget the loss of those who are dear to him, he forgets as a child forgets, but Njerembo proved an exception to the rule. He has been with me ever since the incident narrated above, and was one of my caravan on my very last safari, but he has not married, and I have never known him to have even a sweetheart since the tragic death of his betrothed Asalie. 
Another instance of a wilfully vicious attack by an elephant on human beings, came to my knowledge when I was encamped near the Chiperærie stream, a tributary of the Mbemkuru River. This particular animal was well known to the natives of the neighbourhood, and on account of his decided partiality for the leaves of the tobacco plants which they cultivated in their shambas, they had nicknamed him 'Tombacco.' He had, in his nefarious career, accounted for several natives, and only two months previous to my encountering him, had killed a native woman and her child. The woman in question, with her child tied to her back, was returning to her hut from a visit to a waterhole in the dry bed of the Chiperærie stream, when Tombacco appeared on the scene, drove his tusk through the woman's body, and kneeling on her and her child, crushed them out of existence.

Tombacco was a most sagacious elephant, and, as soon as he knew that he was being hunted, made for the driest and most inaccessible parts of the country, constantly following the wind in his endeavour to outwit his pursuers. On several occasions I had followed his spoor, but he had always managed to evade me by making for tracts of country devoid of water, from which I was obliged to return in the evening to the water-holes near the dry streams to replenish our supply. Eventually, I tracked him 
down from one of the gardens in which he had been sampling the tobacco leaves he loved so well, and managed after a lively piece of hunting to kill him but I was amply repaid for my trouble by his magnificent tusks, one of which weighed I 3 lbs., and the other Io4.

When travelling along the Mbarangandu River, on one occasion, I had an exciting experience with a buffalo. I had stopped to have lunch and await my carriers, who had been following along with my baggage, about half a mile behind; and they had hardly overtaken us, when we heard a succession of terrified yells some distance in their rear. $\mathrm{My}$ trackers and men at once began to make all sorts of conjectures as to what had occurred, some saying a snake had bitten one of the carriers who had lagged behind, others attributing the trouble to an elephant, or a buffalo, or a lion, or a leopard, but feeling that this was rather an unprofitable occupation, I ran in the direction whence the shouts had come, sprinting a distance of about seven hundred yards through the soft dry sand of the river bed, carrying with me my heavy double rifle, weighing thirteen pounds. By this time, all was silence, and fearing that the affair, whatever it might be, had had a serious ending, I plunged, almost dropping with exhaustion, into the long grass in the hope of clearing up the mystery of that succession of 
terrified yells. Suddenly, I heard groans of pain, and making my way in the direction of the sound, came across one of my carriers' servants lying prone in the grass. A careful examination failed to disclose any trace of a wound, so I administered a cupful of brandy as a restorative, and, to my great relief, the poor fellow had soon sufficiently recovered to explain succinctly what had occurred. It seems that he had been loitering along some distance behind the carriers, when, without any warning, a buffalo, having evidently scented us and bent on making himself scarce, had charged madly through the bush, and seeing a human being, had deliberately turned and tossed him. Fortunately, the animal's horn had passed between the man's legs without goring him, and though badly bruised and shaken, he was not seriously injured, so leaving him in charge of some of my men who had followed on my heels, I set out, accompanied by my trusty tracker, Chingondo, on the spoor of the buffalo.

For about half-an-hour, we followed the animal's tracks through the tall reeds and razor-bladed grass which grew thickly along the river banks, plunging at times knee deep in patches of slimy marsh infested with pythons, and all the while keeping a course roughly parallel with the dry bed of the Mbarangandu. All at once, we came up with him, and, catching a brief glimpse of his dull black hide, moving swiftly 
through the dry white reeds, I hastily fired and heard the dull thud of the bullet as it struck him in the flank. Off he went at full speed, and though we now had his blood spoor to assist us in tracking, he soon outstripped us and for a time we lost sight of him altogether. Our progess now became slow, for, apart from the difficulty of moving at any pace through the dense vegetation, it was imperative to exercise every precaution lest he should decide to wait in ambush and charge us, as a wounded buffalo sometimes will. Another fifteen minutes of wary pursuit brought us to where the belt of tall grass verged on the dry bed of the river, and we could see from his spoor that he had crossed this expanse of burning white sand and plunged into almost impenetrable bush on the other side. The prospect of following him into such a country was anything but pleasant, but as I always feel so averse to leaving a wounded animal to die a lingering death, I decided to continue the chase, to the bitter end. Turning to Chingondo, who, by the way, was every inch a sportsman, I asked him if he was game enough to face the very palpable difficulties ahead. 'If you go, bwana, I will follow you. The country may be difficult, but in hunting one must not mind these trifles!' he replied, so in we plunged and once more settled down to the arduous work of tracking. The spoor now took us into a terrible patch of 
thorny scrub, and as we crawled on hands and knees along the dark tunnel left by the buffalo's passage through the elastic vegetation, a tunnel in which it was difficult, in spite of the brilliant sunshine overhead, to see more than a yard or so in advance, we suffered agonies through our hands, arms and legs being lacerated by the spiniferous bush, and irritated by the spicules of the horrible itching upupu. Merging once more into the long grass, we came upon him, standing at right angles to his tracks, and we had crept up to within twenty yards of him, when he caught sight of us and charged. I instantly fired, but owing to the dense grass, accurate shooting was almost impossible, and although the bullet passed a little to the right of his heart, he continued his furious career and was within ten paces of me when I fired again. On this occasion, my bullet ploughed its way through his shoulder but failed to stop him, and, next moment, with a vicious snort, he was upon me. Catching me a sharp blow on the hip with his horn, he flung me headlong in the dense grass out of his way, and the impetus of his charge carrying him past Chingondo, who had dodged nimbly aside, he burst once more out of the belt of bush and floundered a few paces into the bed of the river, where he collapsed in a heap on the soft sand. Badly bruised but otherwise unhurt, I picked myself up 
and finding Chingondo safe and sound, went over to where the buffalo lay dead. Placing the animal in position, I succeeded in getting an excellent photograph of him, the background of the picture giving an admirable illustration of the nature of the bush through which we had prosecuted our exciting hunt.

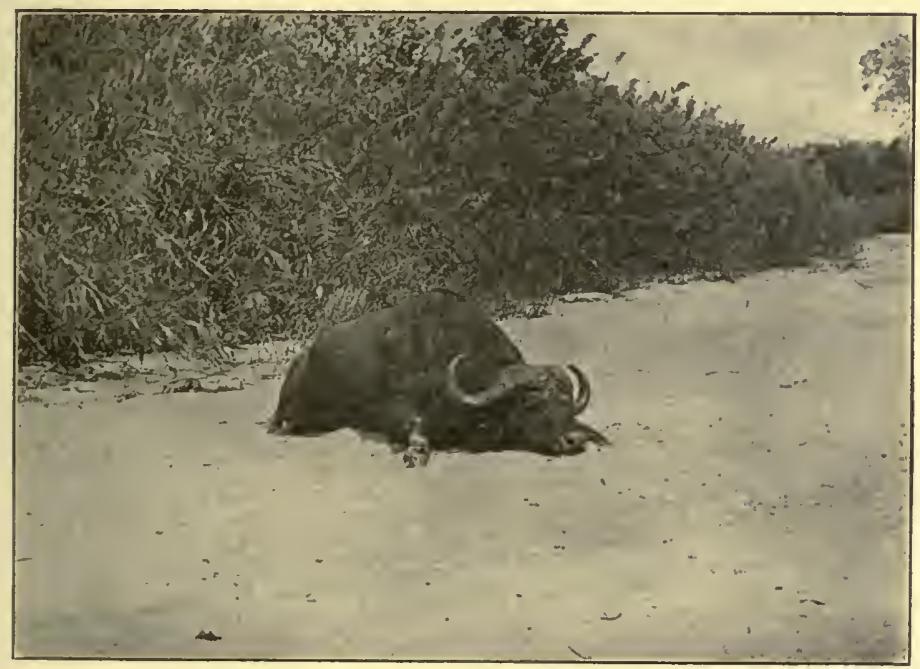

THE BUFFALO THAT TOSSED CARRIER'S BOY.

About a week after the incident related above, I chanced, one day in camp, to hear a very dismal howling in one of the native huts, and asking my boy to find out the cause of the woe, learnt that one of my carriers had been administering a sound thrashing to his servant, who happened to be the very man whom the buffalo of the foregoing story had tossed. Sending for the carrier, I enquired of 
him why he had punished his boy, to which he replied that he had given him a good beating for loitering behind on the day that he had been tossed by the buffalo, adding in extenuation of his severity: 'You see, bwana, had he been killed, I should have had no one to carry my things and cook my food!' 


\section{CHAPTER IX}

THE STRUGGLE OF THE TITANS

ON October IIth, I9II, while in the vicinity of the Luwegu River, we came upon the tracks of a herd of eight bull elephants that had been feeding near our camp during the previous night, and at once started in pursuit. By ten o'clock, we were fast approaching our quarry and knew by the pronounced odour pervading the air that some of the bulls among the herd were very old. (In explanation, let me state here that each animal of the chase gives off a distinctive odour by which the experienced hunter can infallibly tell whether he is in the vicinity of lion, buffalo, water-buck, eland or elephant, etc., as the case may be, or whether these beasts have recently passed.) They were making slow progress, sauntering to and fro, stopping here and there to browse, and occasionally smashing a tree on their way; so congratulating ourselves that there was no wind, and praying that it would hold off, we followed the clear impressions of their 
gigantic feet with the utmost caution through the forest. All at once, we heard the curious, rumbling, intestinal noises that betoken the close proximity of elephants, and seeing a large ant-hill some hundred yards away, in the direction of the Luwegu River, my tracker Simba and I stealthily made our way towards it, and on reaching its summit and peering over, we caught sight of five of the herd, grouped beneath a large haekaera tree, all of them, save one, whose tusks were insignificant, facing away from us. Not far from this group, stood two more bulls, one with tusks, which, I roughly computed, were about thirty pounds in weight, the other, absolutely devoid of tusks, while, to the left of the main group, and nearer to us than the others, the remaining elephant, an enormous brute, showing a magnificent tusk projecting from the right side of his head, had taken up his position. This last tusker was evidently the leader, and as he offered such a prize, I decided to try to bag him first, hoping, too, that his fall would throw his companions into wild confusion and give me a better opportunity of securing a few of them. But as the angle at which he stood rendered it impossible for me to place a vital shot, I decided to wait until he presented a more favourable view. I was, of course, afraid to change my own position lest the other elephants should see me and stampede, and I should, with all 
due deference to the opinions of other writers, like here to discountenance the notion that elephants suffer from weak eyesight. All my experience has taught me that, on a par with their hearing and scent, their vision is extraordinarily keen, and I can only suppose that the misapprehension has arisen from the fact that, owing to the position of his eyes, an elephant cannot see clearly straight in front of him-an entirely different matter.

Now, towards the river, which was about a hundred yards away, and directly before us, stretched a fine open space, covered with trampled and broken grass, and dotted here and there with a few small trees, and as I patiently waited for the large bull to turn, there was enacted in this natural amphitheatre a scene, the like of which, in all my previous hunting career, I had never had the good fortune to witness. All at once, the small elephant, standing beside the tuskless bull to the right of the main herd, beat the ground a few times with his trunk, the action looking as if it were something in the nature of a challenge, and then, quickly crossing to where the large tusker stood, deliberately gave him a blow on the hip with his head and tusks. The assaulted animal, though at first seemingly averse to a conflict, naturally resented the treatment, and turning sharply, struck his pugnacious companion full on the side of the head. Both now began pushing one another with 
their heads, much as bullocks do when fighting, their tusks locked, their gigantic bodies swaying and staggering under the terrific force brought into play, and this silent struggle continued until the larger of the Titans, wrenching his head free, raised his trunk and brought it down with a resounding whack on his antagonist's neck. To this stinging punishment, his opponent replied with a smashing blow on the shoulder with his tusk and, as if desirous of bringing the contest to a close, the larger elephant withdrew and stood some distance apart.

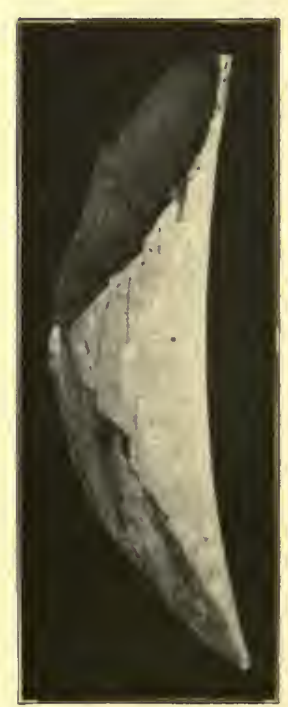

PIECE OF BROKEN TUSK.
Once more, the smaller bull opened hostilities by charging straight at his antagonist, butting him full in the ribs with his head and tusks, the sound of the collision distinctly reaching us where we crouched watching this unique conflict. As I gazed spell-bound, the extraordinary sight, by some strange mental trick, induced a peculiar sense of unreality, and it seemed, as if by some fantastic power, I had been carried back to the faraway pleistocene and was looking on in that morning of the world, at some war of primeval monsters. The larger bull, staggering 


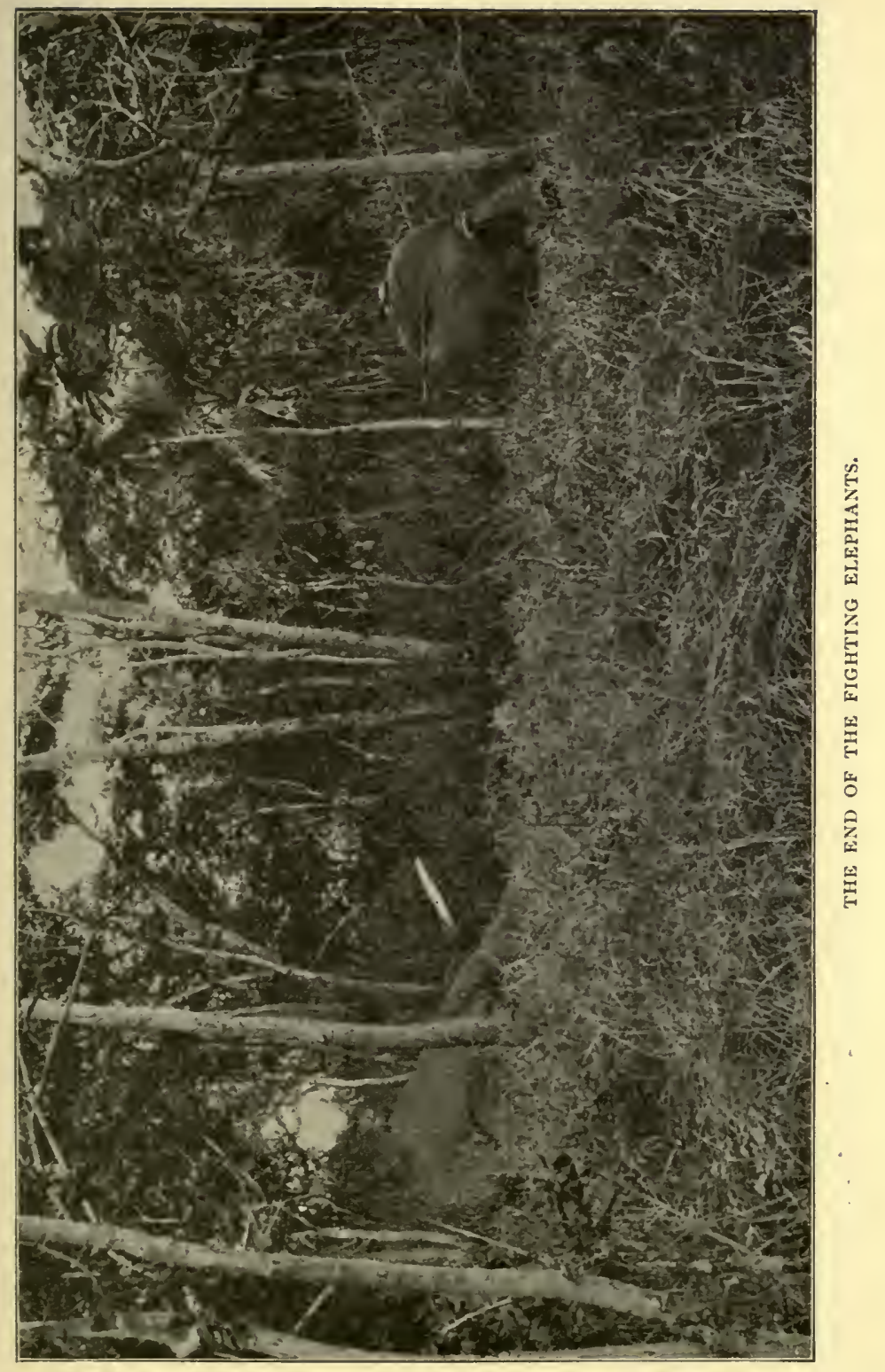


perceptibly under the furious onslaught, appeared for some moments as if he were going to fall, but, recovering his equilibrium, and as if fully intent on avenging the injury, returned the charge and dealt his foe a crushing blow on the shoulder, sideways, with his tusk. The punishment must have been severe, for the younger elephant at once backed out of the fray, but, regaining his courage, pluckily resumed the contest by rushing forward and giving the big fellow a tremendous prod in the shoulder, the force of the thrust snapping off a piece of his tusk. This broken portion I afterwards found, and keep as a memento of the only elephant fight I ever saw.

Seeing that the remaining bulls were growing uneasy, and fearful lest they should get a whiff of tainted air, I decided to bring this unique contest to a close, so raising my rifle and taking careful aim at the large tusker, who was standing broadside on and presenting a perfect shot, I fired, dropping him instantly with a bullet through the brain. I immediately emptied my second barrel into his erstwhile antagonist, breaking his shoulder and snatching my light rifle from Simba, ended the animal's career. The remaining elephants, scared by the fusillade, had already disappeared, so before following them up, we examined the slain. On the larger one's shoulder, we found a huge gash about three inches 
wide made by his opponent's tusk, and from which he had evidently lost a large quantity of blood, the surrounding grass being spattered with gore. From the trampled condition of the ground, it was evident that there had been some preliminary skirmishing before we had arrived on the scene. The tusk of the smaller animal was broken in two places, but the first piece, forming the tip, we never found. From the accompanying photograph, depicting the middle portion of the tusk, the reader can form some idea of the tremendous force brought into play to produce such a fracture in so tough a material as ivory.

As there were no females present or in the vicinity, the tussle between those two bull elephants cannot be ascribed to jealousy-that prime incentive to most of the fighting done by animals of every species-and unless they were quarrelling over some absent love, I must admit that I cannot explain 'what they fought each other for.' 


\section{CHAPTER X}

UPS AND DOWNS IN THE MBWEHU BUSH

One Friday in September, I 909, tired and thirsty, we reached the water-hole at Leoto, about two o'clock in the afternoon, and decided to camp in the vicinity, for, from evidence that is as clear as print to a hunter, I had noticed that two or three big tuskers came there regularly at night to drink, and the chance of bagging one of them ere the moon set, was sufficient inducement for me to stay.

About 9 o'clock, they came stealthily through the bush with a silence that would amaze anyone not acquainted with big game; but ere they had reached the water-hole, some faint scent or sound disclosed our presence, for they suddenly changed their plans and made off rapidly into the moonlit jungle.

Next morning, we were up before cock-crow, and as soon as the light permitted, set out on their tracks of the previous night. My guides informed me that these elephants had been hunted for years by native hunters, and also during the preceding 
rainy season by a couple of Europeans, one of whom during the same season met an untimely end at the hands of an elephant. Hence, they were an extremely wary trio, timid and ever on the alert, apparently, only feeding at night and early morning, and during the day keeping incessantly on the move in the wake of the wind. They gave us ample proof of their shyness and cunning, for all that day we pursued them steadily, and when night closed in with the abruptness characteristic of the tropics, they were still going strong, leaving us to camp, worn out with fatigue and unable to quench our thirst for lack of water. Next morning, we set out at daybreak, and at 8 o'clock reached Limbo waterhole where we decided to rest, hoping that the elephants we had so vainly pursued would come there to slake their thirst when darkness set in, and resolved, should they disappoint us in this expectation, to set out on the morrow in quest of them.

This is, by the way, a heart-breaking country in which to hunt. Stretches of twenty and thirty miles intervene between the different water-holes; there are neither hills nor depressions to relieve the eye or vary the monotony of marching-simply a flat, sullen, expanse of sand, covered with occasional patches of long grass, interspersed with pitiless, thorny scrub which cruelly lacerates any exposed portion of the body or limbs. Tramping through 
this God-forsaken, desolate region under a blinding, blistering sun, is, to put it idiomatically, not all beer and skittles. When parched with thirst at night, we fling ourselves down to dream of silver goblets of wine, deliciously cool, only to wake with parched tongues and realize that we still have some hours to stagger on ere we reach the longed-for goal—a filthy, perhaps evil-smelling pool at which all manner of unclean beasts quench their thirst. On arrival there, my boy makes me the fail-menever drink of tea, a concoction that looks more like pea-soup than that heavenly beverage; but thirst is insistent, and seasoning the liquor with a good dash of Scotch to remove the twinge, I gulp it down. Seeking the shade of some friendly bush, and incidentally having a good look round to see that no snakes are taking advantage of the same shelter, I fling my tortured body on the ground. Physically, I may rest but, mentally, I must be on the qui vive until darkness sets in, in case elephants should come to slake their thirst at the same vile water-hole. There is nothing for it but to live in hope and rouse my drooping energies with another draught of muddy tea and whisky, hoping that perhaps, on the morrow, some tuskers may fall to my rifle, as recompense for all this hardship.

On Sunday morning, to resume my story, we came across the fresh foot-prints of the same three 
elephants that had given us such a rough time of it during the previous two days, and could see by the broken branches strewn in all directions that they had been feeding in the neighbourhood during the night. We tracked them very cautiously till about I I o'clock, when, just as we had come up with them, they got our wind and decamped, but as the immediate country was fairly open, we raced after them. My tracker, Chingondo, owing to the sharp running and the weight of the heavy rifle he was carrying, was soon completely blown, and, on his informing me of his condition, I told him to drop behind. (Chingondo was, moreover, an inveterate chewer of tobacco mixed with a peculiar lime obtained from shells, and was, therefore, never thoroughly physically fit.) Seizing my light rifle from Ntawasie, who had managed to keep up the brisk pace, I put on an extra spurt and gradually got to within a hundred yards of the quarry, but on achieving this, found that I was much too short of breath to shoot quickly and surely, especially as the animals were dodging in and out among the trees. I succeeded, however, in putting a bullet in the neck of the nearest one, who, only staggered by the shot, promptly recovered and rushed off as fast as his legs could carry him. I followed in hot pursuit, and just as he was entering a patch of bush gave him another bullet, which, however, also failed to bring him down, and 
necessitated my tracking him very slowly and cautiously through the dense cover once more. Shortly afterwards, we again came out into the open, and seizing the opportunity afforded by this favourable circumstance, I dropped the monster (he was the largest of the three) with a brain-shot right

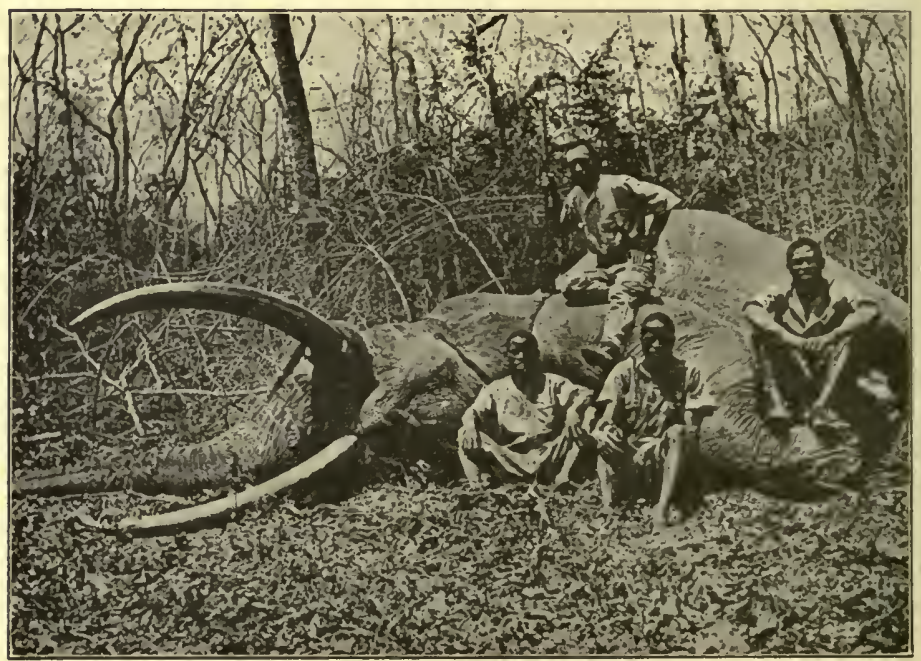

THE DEAD MONSTER

through the forehead. A most extraordinary incident now occurred : just as the elephant fell, one of his companions, who was some distance on the other side of him, at once doubled back and, approaching his fallen friend, gave him a couple of tremendous prods with his tusks. I was thunderstruck, and can only explain the brute's action as an attempt to rouse his comrade, in order that he might escape the 
impending danger. However that may be, he had made the effort in no half-hearted fashion, for, on examination, I found that one of his tusks had punctured a small hole in the neck, and the other had created a horrible wound in the abdomen, through which the outer covering of the intestines

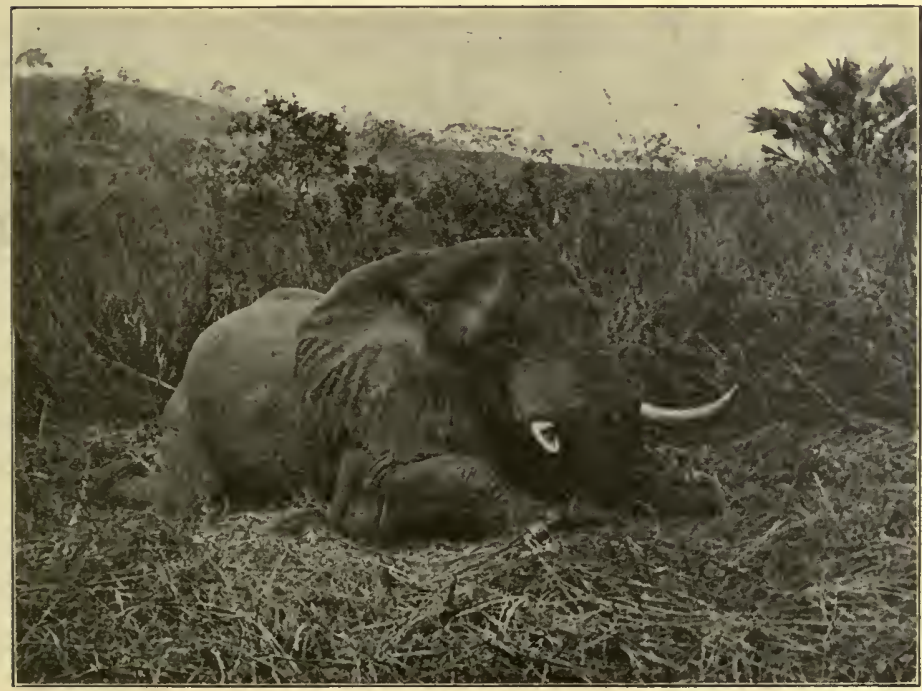

THREE ELEPHANTS SHOT.

protruded in a bunch of skin and fat. Failing to effect his purpose, he was about to bolt, when a couple of bullets brought him down beside the prostrate bulk of the companion, for whom he had deliberately and unselfishly dashed back in the very face of the enemy.

Deciding to try to bag the third elephant, who, in the meantime, had bolted towards the Njenjie 
River, we at once started off in pursuit of him ; but after two hours' tracking, as our quarry appeared to be a long way ahead and still going strong, I decided, ere proceeding further, to indulge in a brief rest to recuperate from the fierce exertions of the morning, and told my two trackers to go and quench their thirst and fill my water-bottles at the river, quite forgetting to keep one of my rifles by me while they were away. The immediate country was fairly open, save for a space some thirty yards wide on either side of the river, where grew that long, reedy grass in which buffaloes and elephants love to roam. Never dreaming that the elephant was in the vicinity, I flung myself down beside a large ant-hill to await my trackers' return, when, all of a sudden, I was aroused by the snapping of twigs, a short distance off, and jumping up, saw the animal, quite unaware of my proximity, slowly approaching the eminence near which I lay. What a beautiful shot he presented, and how I cursed my stupidity for not having kept a rifle beside me! When only about ten yards away, evidently having scented our tracks, he halted and began sniffing the air, and at the same moment, Ntawasie, returning from the river, suddenly burst into view from the dense belt of reeds fringing the bank. At once, the elephant saw him, and uttering an angry scream made for him at a terrible pace, while Ntawasie, scared out of his 
wits, dropped the heavy rifle he was carrying and rushed back full tilt towards the cover from which he had just emerged. Fortunately, my tracker had discarded my weapon before entering the reeds, and running and picking it up, I joined the chase hoping to get a shot at the beast before he had time to

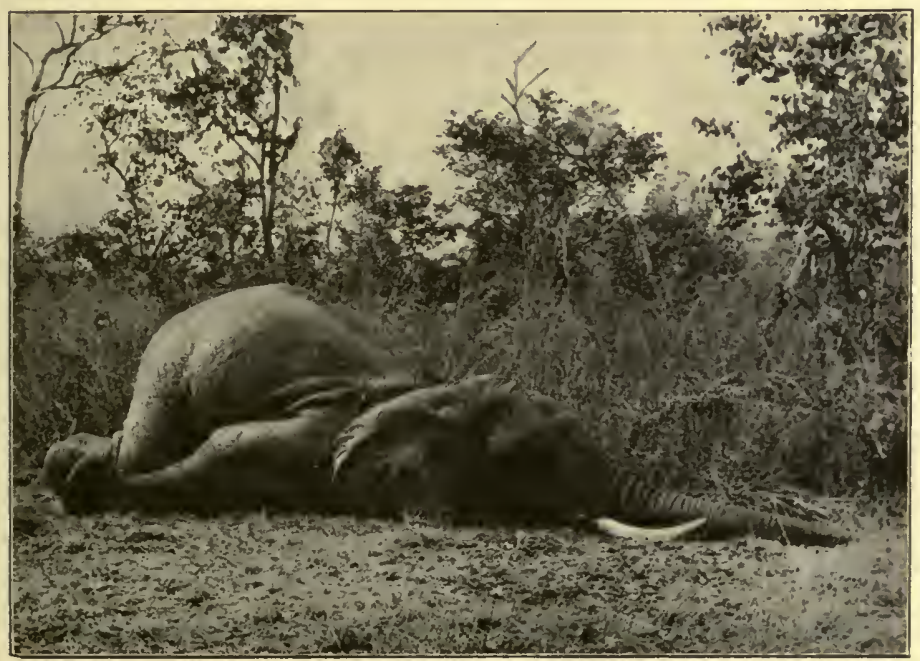

THE 'THIRD ELEPHANT

overtake my man. Ntawasie, in his race for dear life, sped swiftly down one path, doubled back on another and once more emerged into open country, but the ruse, decidedly clever though it was, failed to deceive the keen-scented animal, who, quickly picking up the spoor, also dashed out of the reeds only a few seconds afterwards. My tracker, seeing the brute still in pursuit and feeling that his fate was 
sealed, began to cry 'Bwana! bwana!' in an agony of terror, and hearing his screams, I dashed back out of the reeds and came into view of the elephant, who promptly gave up the chase of Ntawasie, lowered his massive head and charged full tilt in my direction. It was with an intense feeling of relief that I saw his change of plans, for, having a perfect view of him, I felt little anxiety as to the result of the encounter, and as he came charging on, I met him with a bullet slightly above and right between the eyes, bringing him to earth with the crash of a falling tree.

After this little adventure, I took particular care, when following up elephants, never for an instant to let my rifle be out of reach of my hand.

Altogether, the bag had been a good one: the first elephant yielding tusks weighing ${ }^{2} 5^{2}$ and I $37 \frac{1}{2}$ lbs.; respectively ; the second, 64 and $7 \mathrm{I}$ lbs. : the third, 47 and 52 lbs. 


\section{CHAPTER XI}

THE IHITE TRAIL

NEAR the Kibali Hill, at the source of the Bangalla River, I had, some years ago, a peculiar experience with an elephant. During the forenoon, I came up with him as he was placidly making a meal on the juicy fruits of the mbura tree-a largestoned, brownish golden fruit of which elephants are peculiarly fond-but, a clump of small trees intervening between me and my quarry, shooting was a matter of extreme difficulty, and the first bullet from my 577 , instead of penetrating his brain, went slightly high, and with a hoarse scream, the animal promptly bolted. After about another hour's tracking under the direct rays of a broiling tropical sun, we came up with him again, and so little impression had my first bullet made on him, that he had once more stopped to feed, and when we actually caught sight of him, was sucking up water from his stomach with his trunk and sending it in a refreshing spray over his back. Trusting to take him unawares while indulging in this cooling 
shower, we crept closer and closer to him, exercising every caution in our approach, but some whirling eddy of air must have betrayed our presence, for, all of a sudden, he ceased his ablutions and tore headlong through the bush.

About half-a-mile behind me, my carriers were following up with light loads, and one of their number. Baramaesi by name, carrying a sack of rice, had lagged somewhat behind the others, doubtless dreaming of pleasanter things than the presence of a wounded tusker. The elephant, however, had doubled back in a semicircle, and was about to cut across his previous tracks, when he caught sight of the luckless Baramaesi. Without standing on any ceremony, he charged furiously at my carrier, who, quite undesirous of a closer acquaintance with the brute, flung down his sack of rice and scuttled through the bush for dear life. As I was cautiously following up the elephant's tracks, the terrified Baramaesi burst into view, an apparition of flying legs and wild eyes, and seeing us, came tearing in our direction. Though it was doubtless an agonizing situation for the poor fellow, he presented a most ludicrous spectacle, and even now, when I remember the incident, I am obliged to laugh. At the time, however, it was no laughing matter.

'What's the matter? What's the matter?' I whispered, trying to bring his frightened wits to 
bear on the situation, and, recovering his senses with some difficulty, he breathlessly told me what had occurred. It appears that when he had flung down his sack of rice, the charging elephant, evidently mistaking it for a human being, had immediately turned his attention to the load and vented his pent up anger on the unoffending object.

I at once made Baramaesi lead me to the spot where the incident had occurred, and on arrival there, we discovered the grass all trampled flat and rice strewn in every direction, but not a vestige of a trace of the sack. It was clear that when wreaking vengeance on the load, he had transfixed it with one of his tusks and had dashed off without being able to rid himself of the incumbrance. For half a mile on his tracks, we discovered a continuous white trail of rice, when it abruptly ceased, and though we followed his spoor for miles we never came up with him and saw no further trace of the empty sack.

Afterwards, when talking over the incidents of the day, my men indulged in roars of hearty laughter over the ridiculous spectacle that Baramaesi had presented when leaping wild-eyed through the grass, and Baramaesi had received such a fright on this occasion that he never again joined one of my safaris. Discussing the curious incident 
of the elephant making off with the sack of rice, one of my men, Manjora, who is the wag of the party, remarked :-

' Oh, he has taken it away to make a little shamba (garden) for himself in some far-away nook of the forest!' and this idea so tickled my men that they made a stock joke of it and, when recalling the affair, its repetition never failed to produce roars of laughter.

\section{II}

\section{The Wizakd Elephant}

Towards the close of I9II, near the Mewalie stream, a tributary of the Luwegu, I met with a most extraordinary experience.

Just after dawn, as we were on trek through the bush, we chanced upon the spoor of several bull elephants, and after about two hours' tracking came up with them under a clump of beautiful palms. They were engaged in butting at the trunks of these graceful trees with their heads, making them rock to and fro to shake down the large tough-skinned fruits which they are fond of chewing. As we approached, however, the wind unfortunately gave them our scent, and sent them crashing away at a great pace, but ere they had disappeared, I brought down 
the hindmost with a head shot. On approaching, I discovered him lying on his side groaning, as a dying elephant does, and to put him out of pain placed the muzzle of my 318 rifle within a foot of his head, at the correct angle to reach his brain, and fired. As soon as the bullet struck him, his huge body was convulsed with spasmodic tremors and his tail stiffened-symptoms invariably evinced by a recumbent elephant when he has been shot in the brain-and I naturally inferred that he was dead. Moreover, I have finished scores of elephants off with this identical shot.

My tracker, Simba, now mounted the beast's body to get a better view of the surrounding bush, while I sat for a five minutes' 'breather' on the animal's head before starting in pursuit of the remainder of the herd. Refreshed by the brief rest, we set out once more on the spoor, but discovering after about half-an-hour's work, that the cunning beasts, in an endeavour to get our scent were beginning to follow the wind, which was variable, I decided to call a halt for about an hour to see if the currents of air would either subside or blow steadily in one direction. Bidding one of my boys make tea, I sent Simba back to cut the tail off the dead elephant. In about three-quarters of an hour, he 
returned and, with astonishment written all over his black face, imparted the startling information that the elephant had vanished! So dumbfounded was I at this extraordinary news, that I told my tracker he must have taken leave of his senses, and poor Simba, feeling somewhat hurt at my casting ridicule on his statement, could only assert more positively than ever that he was speaking the truth. Knowing that my man was a most reliable and accurate native, I was at length obliged to credit his statement, and picking up my heavy rifle, I hastened in his company to where the elephant had fallen and lain. On arriving at the spot, we could see from the marks on the ground how the animal had struggled to regain his feet, and how from the trunks of some of the surrounding trees he had scrubbed patches of bark as he had lurched against them in an effort to steady himself. On following up his spoor, we also learnt from the impressions made by his toes in the ground, and the way in which the grass had been brushed aside, how his manner of progression had gradually. changed from staggering to a firm gait, and from a firm gait to a good steady pace. For six solid hours, we kept relentlessly on his tracks, but had utterly failed to come up with him when night put an end 
to the pursuit and. obliged us to pitch camp on his spoor. Next morning, we discovered, to our chagrin, that, after meeting with a couple of other bulls, he had in their company joined a herd of females, and as there was no blood spoor and his tracks were identical in size with those. of his male companions, it was impossible to discriminate between them-factors which led to our subsequently losing him altogether.

Naturally, such an incident, explicable enough in the light of reason when all the details are known, at once shrouds itself in a mist of fantasy to the native mind, and, even to a European, borrows some faint shadow of mystery from its setting in lonely bush in a land where mysteries are many. Such an effect had it on my tracker, Simba-at other times an unusually rational native-that on our return to camp he came up to me and said gravely :-

'Bwana, that was no elephant; he was majavie (wizard). In all our experience such a wonderful thing has never occurred. First of all, you shot him through the brain; then, as he was lying groaning, you again shot him through the brain, and all his limbs trembled as if he were dying. I stood on his side and you sat on his head and not a tremor went through his frame. Then he gets up and goes away! No, bwana, he was not an elephant; he was certainly majavie!' 


\section{CHAPTER XII}

TIIE RAID

Aт the present day (in the year 1912), there are, in Portuguese East Africa, vast tracts of country where law and order are things unknown-such as, for instance, the region that extends from the Mavia country, east of the Lujenda River (a tributary of the Rovuma), southwards towards British Nyassaland and westward to the shores of Lake Nyassa. Here, but in a modified degree, the same social conditions exist as have existed from time immemorial. One petty chief is continually at variance with another petty chief, and, save in those instances where common cause is made against the hated Portuguese and their régime, every man's hand is against his brother man. In this vast region of primeval forest, dotted with numerous native villages inhabited by a goodly population, there exist only two or three Portuguese bomas or forts. There are, I admit, several outposts (each manned by one European and a few askaris or native soldiers) which masquerade under the name 
of bomas, but the authority they exercise is feeble and confined to their immediate vicinity, while beyond their spheres of influence rapine and pillage and murder are rife.

The hilly plateau that walls in the eastern shore of Lake Nyassa is inhabited by the Wyao tribe under several chiefs, of whom the most powerful and notorious are Mataka, Malinganiro (orKisombi), and Makanjira. These people are the descendants of the slave-raiders, hunters, rubber and wax collectors of old, from whom were mostly recruited the dreaded Rukaruka, the force employed by the Arab traders to conduct their caravans of slaves and ivory to the coast. A certain admixture of Arab blood has crept into their composi-

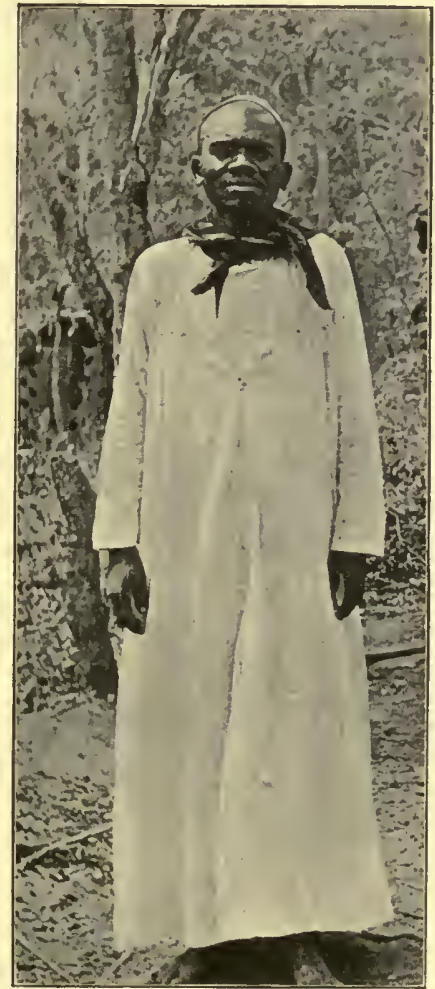

A TYPICAL 'WYao' HeAdMaN. tion, rendering them braver and more enterprising than their lowland neighbours, and they are, today, the prime source of most of the turbulence 
that exists. In by-gone days, they used to regard the thickly-populated and fertile country fringing the lake shore, and that forming the basin of the Shire River as their happy hunting grounds; for in these districts were to be obtained all that their hearts coveted-cattle and slaves and concubines! Hunting and slaving along the Shire River, however, ceased to exist on the advent of British rule, and now the operations of these lawless chieftains are confined to the territory running from the eastern shore of Lake Nyassa westwards to the Lugenda River, and far northwards to where the Rovuma divides Portuguese from German East Africa. I know, for an absolute fact, that Mataka's people still combine with Malinganiro's and carry out pillaging expeditions against the natives in Melanji's country, their forays extending even to Unangu, where the University Mission has a station in charge of one of its native missionaries. And that the reader may thoroughly appreciate the enormity of such a horror, I shall endeavour to describe a typical raid, which actually came under my own personal observation and that of my friend, R. Battley, at Kisumba, some five or six miles from the Portuguese Collectorate at Matengula on Lake Nyassa.

It is night, as dark as an African night can be, and over all the hush of a wonderful peace, broken 
only by the low murmurous lap-lap of the lake, now sinking to rest after a tumultuous and stormy day. Inside the village huts, the native families are contentedly sleeping, one of the members waking now and then to replenish the family fire, which is seldom allowed to die out, while all are blissfully unconscious that danger is at hand, or that the shadow of death, swift and brutal, is drawing nearer and nearer-such is, at times, the sublime cruelty of Fate! Outside, under cover of impenetrable night, silent sinister shapes move stealthily about and finally take up their positions in ones or twos at the door of every hut-these are the raiders, prepared and eager for their foul work. For a space, all is intensely still, and then, in the vicinity of the headman's house, there suddenly appears, in vivid contrast with the intense darkness, a mysterious, glowing red spot, which just as suddenly vanishes. A raider has carried a smouldering stick from the last camp fire and thrust it deep into the dry, inflammable thatch of the roof. In a few moments, the smouldering grass is blown into little, licking flames which, caught by a gusty breeze, leap into long, shooting tongues of fire, which, hissing and crackling, illuminate the surrounding huts and forest in a ghostly glare. The roar of the conflagration soon wakens the occupants of the blazing hut, and 
there rings out on the night the startled cry of 'Moto! Moto!' (Fire! Fire!). Out rush the unsuspecting inhabitants to assist in extinguishing the flames, and as they emerge from their doors, spears and knives flash, rifles crack, and dark bodies fall heavily into the dust, writhe and quiver and finally lie still. Realizing in a frenzy of dread that they are the victims of another raid, the unhappy villagers raise the shrill and fear-instilling cry of 'Nkondo! Nkondo!' (War! War!). A wild panic now ensues; terror-stricken natives run hither and thither, shrieking; those who have escaped the immediate attentions of the raiders and have not lost their presence of mind in this dire extremity, dash swiftly into the pori (forest), and get away from the scene of butchery under cover of the friendly darkness. Groans of pain and piteous cries of entreaty fill the air and mingle with hoarse shouts and fierce oaths where, here and there, a villager, brought to bay and determined to sell life dearly, fights tooth and nail until overcome by superior numbers. And amidst all this hubbub can be heard the low, moaning cry of the native who is mortally hurt and in his dying moments invokes the aid of the woman who gave him birth--'A mio! A mio!' (My mother! My mother!)—a cry that will haunt those who have heard it throughout a lifetime. 
The young women and children, shivering with fear, and afraid to utter a sound, lest a piteous cry or an appeal of any kind be answered with a swift knife-thrust or a brutal smash with a riflebutt, stand herded together, surrounded by a ring of warriors. Those of the old men and women who have failed to make good their escape are lying stark and stiff at the doors of their huts!

Time is passing swiftly, and as those who have fled will carry the news to neighbouring villages and return as quickly as possible with succour, it behoves the raiders to make all haste with their booty back to their fastnesses in the hills. The captives, guarded strongly on all sides, are therefore, hustled and hurried along without rest, day or night, the laggards and weaklings being mercilessly flogged with whips made of hippopotamus hide. A stronger body of raiders follows up to guard the rear and frustrate any attempt on the part of pursuing villagers to regain their wives and children, many of whom will never again set eyes on home and kith and kin.

All of a sudden, a male captive, whose mental suffering is keener than any physical pain that human hands can inflict on him, falls out.

'Meme siwaesi, bwana wae, nemechoka, unguvu simequeisha!' he cries. (I am unfit, my master, I an done, my strength is utterly finished!) 
'Bas hia, gufa mauna halam, poteraeah bali!' (All right, it is finished, die you son of a heathen! Go to perdition!) comes the gruff reply, and a knife is plunged into his heart without further ado.

On the other hand, should the recalcitrant be a handsome girl, she is subjected to the most infamous indignities in order to induce her to proceed.

Dawn breaks over a desolate village. Here and there, in the hot sunshine, lie silent, dusky bodies, punctured or gashed, while at times, from the bush, a scared, wild-eyed face will cautiously peer to see if the War God has passed, so that the remains of those near and dear may be saved from the ghastly attentions of the already wheeling vultures.

Away up in the hills, where the captors are dividing their booty, an altogether different scene is taking place. Wild excitement reigns, and there is a deafening hubbub, for the captives, especially the females, are being carefully inspected and appraised by their captors with coarse jokes and ribald laughter. Each warrior claims his individual capture (not without occasional bickering and quarrelling among rival claimants), though the chief may appropriate any woman that he particularly desires, the loser having to surrender her with good grace. Children are torn shrieking from their mothers, and, without any compunction, at once sold to natives 
hailing from remote villages; the young women are either bartered or kept by their captors and added to their households as concubines. No sentiment whatever is displayed for the feelings of those poor souls, who are being shared out as if they were inanimate objects.

It seems atrocious that such a state of affairs should be allowed to exist at this very day in a territory administered by a so-called civilized, European Government. 


\section{CHAPTER XIII}

\section{STIRRING TIMES AT LECUNDI}

IT was on December 20th, 1909, while the majority of people at home were distraught over the vexed subject of Christmas presents and busy preparing for the hundred and one amenities of the festive season, that I was on safari towards the coast with my men and their wives and children. We had had a couple of uneventful weeks, but the Fates were going to recompense us fully for the dull time by some excellent excitement. We were making for the upper reaches of the Mbarangandu River, when, near the Lecundi stream, we came across the fresh spoor of a herd of elephants. On our approach they winded us and decamped, but, determined not to let them escape, I set out on their tracks with four of my men, leaving the rest of the caravan to camp and await our return. A couple of hours' tramping brought us up to them in a country abounding with long grass, but they scented us once more and, as they went crashing off through the tall growth, I 
put a quickly-aimed bullet through the neck of the only one I could see, and brought him down instantly. Without wasting time, we dashed after his fellows. What a chase they gave us! We crossed and recrossed the Mbarangandu River, wading knee-deep through the water, and tore

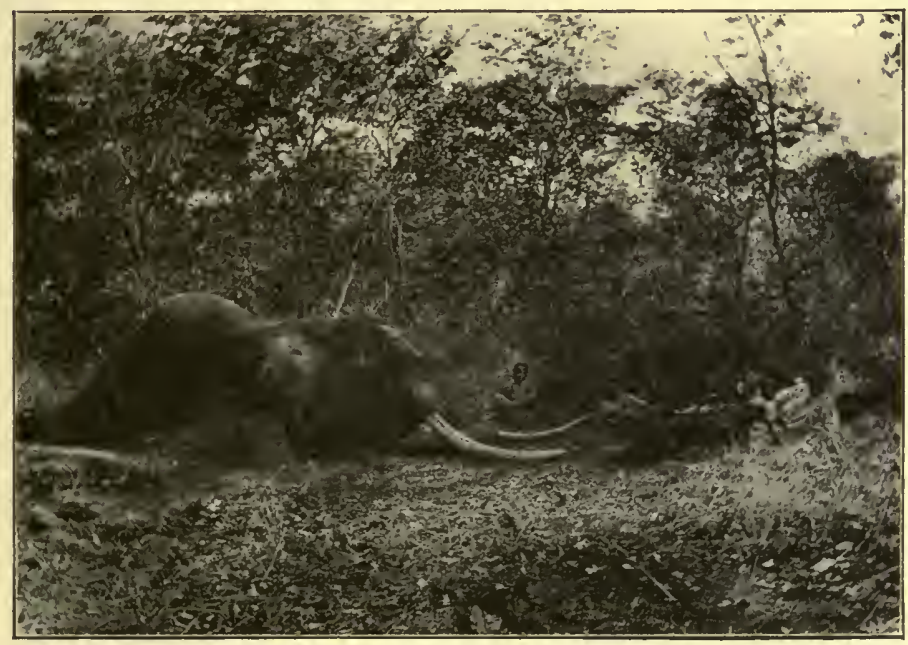

THE FIRST ELEPHANT.

through long, dense elephant grass, full of itching upupu bean, at times running almost doubled in two along the tunnel formed by the reeds after the elephant had passed. Under such conditions as the last mentioned, tracking elephants is nervous work, for it is quite impossible to see more than a couple of yards in any direction, and should an animal double back on his spoor and charge, there is nothing left to 
do but face the monster and hope for the best. All at once, Simba, who was just in front of me carefully following the spoor (while I followed with rifle almost touching him, ready for instant action in case of emergency), grew rigid and pointed to the path a few feet in advance, across which an enormous black snake, having either seen or heard our approach, was gliding, hissing angrily as it went.

'Bwana, bahati sana!' whispered Simba, meaning, 'Master, this presages great good luck!'

Letting the reptile pass, we grimly pursued the elephants' spoor, and about five o'clock came up with our quarry where they had been feeding in a small patch of bush. Carefully as we had approached and in spite of Simba's rosy predictions, they succeeded in getting a sniff of our tainted air and bolted. Exasperated with these successive disappointments, I felt that something in the nature of a desperate attempt was imperative, and just as they were making off, I dashed full speed towards a clearing, a few hundred yards further on to our left, in the hope of outflanking them, for I fully expected that, in an effort to reach a large patch of reedy grass beyond, they would traverse this intervening open space. I was just in time to see two of them on the point of vanishing into this convenient cover, and swinging my rifle, took a snap-shot at the hindmost, luckily 
hitting him, as I subsequently discovered, in the heart. Dashing madly forward, I was astonished to find the animal only a few yards within this belt of vegetation, lying on his side, apparently dead, with his back towards me. As I approached, somewhat incautiously I admit, he viciously swung

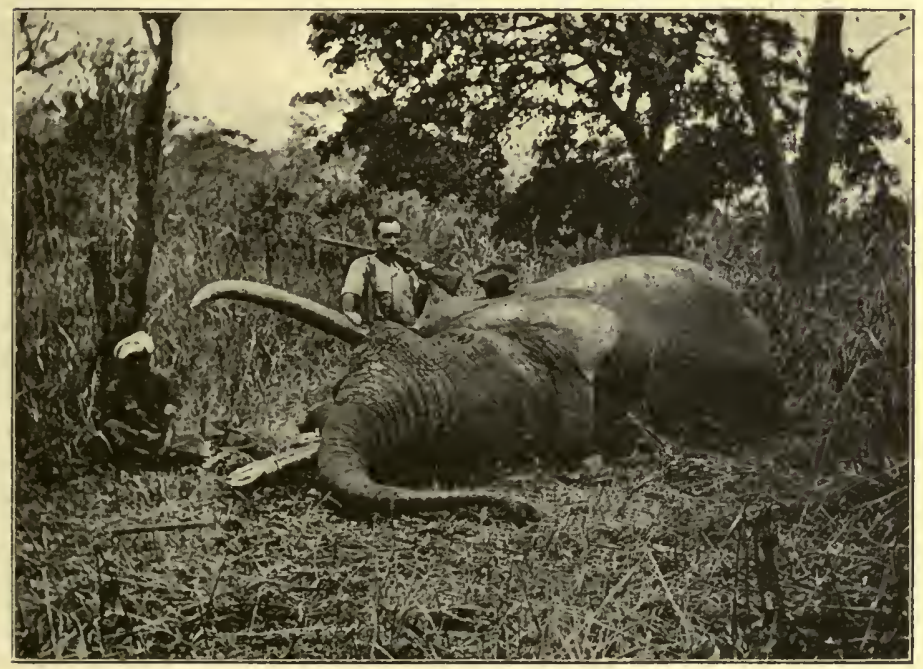

ONE OF THREE EI.EPHANTS SHOT ONE AFTERNOON.

his head and trunk round in an endeavour to catch me, but, instinctively alert for any such offensive move, I instantly sprang back out of his reach and, kneeling down, gave him a finishing shot in the brain.

While examining our prize (a beauty, with tusks scaling 83 and 84 lbs.), we suddenly heard, to our surprise, the noise of an elephant smash- 
ing his way through the bush in our rear, on the other side of the clearing whence we had come; and imagining that this was another tusker altogether and not the dead one's companion who had circled round, I snatched my rifle from my gunbearer and rushed back, followed by my trackers, Ntawasie and Simba. Though we gradually approached, up-wind, to where we could distinctly hear the noise of his movements in the long grass, he must either have seen or heard us, for when we were within thirty yards of him, he suddenly charged us with lowered head, bursting through the bush like a runaway railway engine, and carrying a mass of broken branches and sundered vegetation on his tusks. When he was within twelve yards of me, I fired a right and left in quick succession out of my double 577 , striking him in the forehead, but though momentarily staggered by the impact, he recovered and came thundering on! As there was no time to reload, and it was quite impossible to snatch my light rifle from my gunbearer behind me or get out of the elephant's way owing to the dense bush, I felt that my fate was irrevocably sealed. In this awful moment, when I had given up all hope, and expected within a few seconds to be trampled out of recognition, a bullet screamed past my head and struck the elephant in the eye, making him swerve 
aside. This bullet most indubitably saved my life, thanks to my trusty tracker, Simba, who, seeing my predicament, and being only a few yards behind, had promptly fired my 10.75 rifle in the elephant's face. Springing back at once, I hastily snatched the rifle from my man's grasp and rained the three remaining bullets into the retreating elephant, the denseness of the bush, however, preventing my placing a vital shot. $\mathrm{He}$ at once sought cover in almost impenetrable elephant grass, fully twelve to seventeen feet in height, clearing a narrow path from which it was impossible for a man to diverge a foot, owing to the intensely compact growth which rose as impervious as a solid wall on either side. Knowing that it would be futile to follow him up in this awful jungle, I ran to the right in the hope of rounding him off, and made for a hill comparatively free from vegetation about two hundred yards further on, calculating that, if the animal had not already collapsed among the long grass, I should probably get home a decisive shot from that eminence. My conjecture proved correct, for on reaching the summit of the hill I could see him dragging himself along among the giant grass-evidently in extremis, so handing my heavy rifle to Simba and grasping my light rifle, I dropped the animal with a bullet through the heart. This was rather a fortunate shot, for, the length and denseness of the grass only allowing me. 
an occasional glimpse of the top of his back,' heart and brain shots were entirely a matter of guess work. Upon coming up to where he lay, we found him lying on his side moaning, so I put him out of pain with a 577 bullet through the brain.

When my men were chopping out the tusks of the

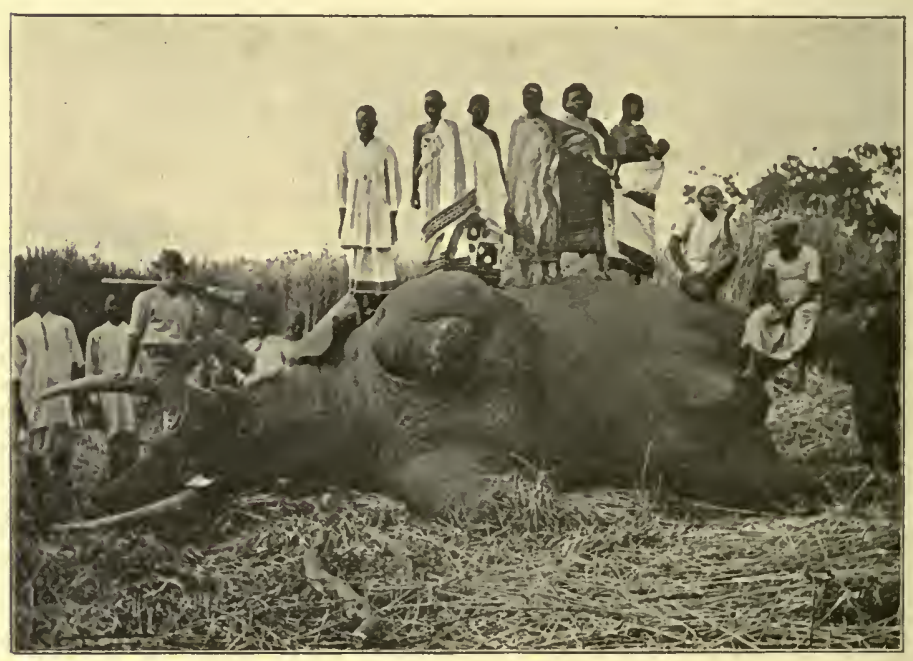

ELEPHANT WITI SOME OF MY MEN AND THEIR WIVES.

latter elephant, my head tracker, Simba, came up to me saying that he couldn't understand why the animal had not succumbed to the first two shots, which, in his opinion, had penetrated the brain. This conjecture we proved to be correct, for Simba, removing with his knife the skin of the forehead from about the wounds, and chopping a hole in the skull, inserted his hand along the course of the bullets and with- 
drew a portion of the brain matter. I, myself, made a most careful examination and satisfied myself beyond all doubt that both bullets had smashed through the cerebrum. Now these solid, nickelcovered bullets weighed 750 grains each, and were driven at a muzzle-velocity of considerably over 2000 feet per second, and how an animal could travel several hundred yards and live for fully half an hour after receiving such terrible wounds, I cannot for a moment imagine.

Though it is my experience that in ninety-eight cases out of a hundred, a bullet through the brain instantly kills an elephant, on two or three occasions I have pierced the brains of large elephants with small bore bullets without dropping the animals, and have been obliged to finish them off afterwards.

I may here add that, after every kill, I most minutely scrutinize the course and effects of the bullets, and the sum of my experience has taught me that, even with the best and most powerful of modern rifles, I can never be absolutely certain of stopping a charging elephant.

\section{II}

About three o'clock next afternoon, some of my men, who had gone back to chop the tusks out of the first elephant shot on the previous day, returned 
with the report that they had encountered the spoor of two large elephants which had passed close to my camp about half an hour before. At this good news, I immediately set forth, taking with me my two trackers, Simba and Ntawasie, and my boy, Tweegah - the last carrying a couple of water-bottles.

After about half an hour's spooring, we came up with our quarry, who were peacefully resting under the spreading branches of a magnificent nquaju tree, and every now and then tearing down a small branch and consuming it. With their extraordinarily keen scent, they became aware of our presence, and, to our disappointment, stampeded off wildly in different directions. We gave chase to the larger one, the impressions of whose feet in the soft dry sand were enormous and led us to hope that his tusks would prove of exceptional size.

He showed himself a most wily old brute, for he promptly took to the cover of long elephant-grass, and for more than an hour kept dodging and following the wind, leading us through a terrible country, covered with a dense jungle of entangled vegetation, full of the insufferable upupu bean, and broken here and there by an occasional open space with trampled grass, where elephants are wont to rest. Just as the sun was setting, Ntawasie, descrying our quarry, suddenly dropped to his knees and pointed to a large tree, behind which the animal 
was standing, most likely on the look out for his pursuers.

Owing to the shade of the tree and the surrounding thicket of tall grass, a decisive shot at the animal was impossible, for I could only discern the top of one enormous ear, and the tip of his trunk, the latter uplifted and sniffing for our scent. The difficulty now was to decide on some satisfactory plan of action, and I felt it would be inadvisable to tempt the brute to charge us, for it is no easy matter to place a bullet in a vital spot when the approaching animal is almost entirely hidden by dense grass until he is actually on you. Finding that the wind had completely dropped, and noticing, about three hundred yards to our left, a hillock from which it was probable that I should be able to get a better view of the elephant, we retraced our steps for some thirty paces, and cautiously made our way towards this eminence. From its summit, I could dimly discern our quarry, so fixing a telescopic sight to my light 3 I 8 rifle, I discovered that he had left the shade of the tree and was now standing in the long grass at an angle to the path which he had made. Above the vegetation, I could clearly see his gigantic black ears flapping, and being able, thereby, roughly to calculate the position of his forehead, I decided to risk a shot, knowing that if I deferred matters much longer the failing light would make it impossible 
to take definite aim. Adjusting the telescopic sight to four hundred yards, I fired for what I took to be the centre of his forehead, but, the bullet striking him too high, he uttered a shrill scream of rage and charged in our direction. As he came on; I gave him a second bullet in the face, which deflected him from his course and sent him crashing through the reeds to our left. Fearing that I was now going to lose him, I got Ntawasie, a fine strong, strapping fellow, to hoist me on his shoulders, and from that coign of vantage I quickly emptied the three remaining cartridges out of my magazine into the departing elephant, trusting to reach a vital spot or further disable him, but they failed to bring him down, and, shortly afterwards, the bush had again swallowed him up. Suddenly we heard a terrified yell —and a distinctly human one-coming from the direction which the animal had taken, and, Simba, turning to me, said excitedly:--'Master, the elephant has met our men who are following us up,' and his conjecture, as we subsequently discovered, proved to be correct. What had actually happened was as follows. My cook and my other boy, Usufu, fearing I might be obliged to pass a night without food or water, had hastily packed a few necessaries together and followed us up, and on hearing the firing had departed from our tracks and veered to the right, only to meet the elephant rushing madly 
in their direction. They promptly made themselves scarce, and the enraged animal, having no currents of air to assist him in locating them, kept dashing hither and thither through the bush in an effort to hunt them down. Seizing my double 577 , I rushed off, accompanied by my trackers, in the direction of the yell we had heard, and had not gone far, when I encountered my cook tearing headlong through the grass, his eyes starting from his head with sheer terror. In a few words he explained what had occurred, saying that poor Usufu had most likely been killed, for when they had met with the elephant they had scattered in different directions and the animal had dashed off in pursuit of Usufu. Making the cook accompany me to show me where he had separated from his companion, I hurried along, fearing that the worst had happened, and, on arriving at the spot, listened with strained attention for any sound that might indicate the whereabouts of my boy or the elephant, but a most ominous silence reigned over the scene. As the sun had now sunk behind the hills, and the light was fast failing, we cautiously followed the elephant's spoor, and had made very little progress, when, all at once, we heard a succession of short, shrill screams, and the noise of the animal dashing back through the bush on his own tracks, right in our direction. When he was within a few yards of us, I fired both barrels in his 
face, dropping him on his knees, and ere he had time to rise and try conclusions with us, I snatched my second rifle from Simba and gave him the coup de grâce with a bullet in the brain. Leaving the animal, we instantly set out in search of Usufu, calling his name loudly as we went and hoping

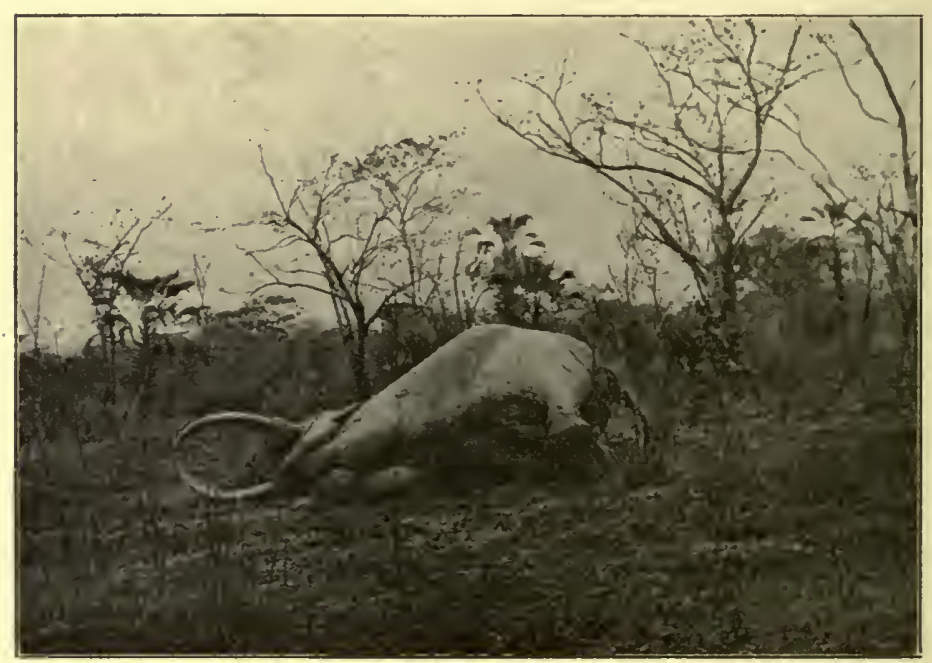

ELEPHANT WHICH CHARGED ME AND NEARI,Y KILLED MY BOY, USUFU.

against hope that he might still be alive. To our intense relief, we soon heard cries of 'Bwana! Bwana!' which we knew proceeded from Usufu, and ere many minutes had passed, he turned up, none the worse for his exciting adventure.

In relating his experiences, he told us that when the elephant was almost on him, he had flung down the package of food which he had been carrying for 
me, uttered a yell and sprung aside into the reeds, and the animal, getting the odour of a human being from the load, had promptly left him and turned his attention to it, evidently taking it for a convenient victim. Having driven his tusk through it and trampled it out of all recognition, he had quietly walked away, satisfied that he had accounted for his man, who, having cautiously made his way to a tree near by, had climbed it and been an eye-witness of the whole performance.

We pitched camp in a clearing a few hundred yards from the spot where the tusker had wreaked his vengeance on our food supply, and though deprived for the night of these necessaries, we were inclined to be in a cheerful mood, especially after a meal of toasted elephant's heart, for we were conscious that we had had a most exhilarating time, and though of close shaves there had been a few, everyone was safe and sound. Close shaves, moreover, are the fare that the elephant hunter fully expects, and to him, of all people, the old saying, 'All's well that ends well,' peculiarly applies. Moreover, the ivory resulting from the two days' hunt reached the grand total of $623 \mathrm{lbs}$, not at all a bad Christmas-box from the hands of Fate. 


\section{CHAPTER XIV}

SNAKES

Though the snake does not account for so great a number of natives as either the lion or crocodile, it is a source of danger ever present to the mind of him who dwells in the pori, so much so that, after some years of life in the wild, the mind becomes instinctively alert to the possibility of encountering these reptiles, and when trudging through the bush the eye is always on the watch for them. In this respect, the native's vision is intensely keen, and the readiness with which he distinguishes the reptile's body from the very similar appearance of the dense vegetation around is astonishing. Before spreading a blanket on which to lie, it is always customary to scrutinize the ground for snakes, though I have often seen natives, with their happygo-lucky natures, fling themselves down without a thought.

Once, when travelling between Beira and the Zambesi River, as my carriers were a long way ${ }_{13}{ }^{3}$ 
behind with my camp equipment, my men and I had settled down under some thick shrubs to pass the night. It was a night of torrential rain, and having warmly wrapped myself up in my blankets, which I had fortunately brought along with me, I was about to fall asleep, when I felt a chill, slimy contact with my skin and knew that a snake had crawled under my blanket and curled itself up between my legs. It was a horrible predicament; if I moved and alarmed the reptile, I should probably be bitten and die a painful death within a few hours, for all my medicines. were behind with my baggage, so calling as quietly as possible to two of my men and explaining the situation to them, I asked them to remove, with the greatest care, the blanket covering me. This they did, disclosing a large puff-adder that had probably crawled into the position I have described to seek warmth and shelter from the downpour of rain. Telling my men to put their arms gently under my shoulders and at a given signal to pull me with all their strength clear of the danger, I counted one, two, three, when they both heaved with a will, while I simultaneously flung my legs apart to avoid further contact with the reptile. I was simply shot clear of the danger, and the snake, alarmed by the movement, was about to make off when my men despatched it with sticks. 
On another occasion, when we were hunting, one of my trackers came across his brother, who was out in the forest in quest of honey and bees-wax, and as we were not actually on the spoor of elephants, they went off together to try to kill some rock rabbits. They had not gone far, when they started one of these rodents and my tracker, flinging his stick, broke the animal's leg. At once, the rabbit darted into its burrow, under a large boulder, and my tracker's brother, running up, thrust his hand into the hole to pull out the wounded beast. Something promptly seized him by the finger, and, for a moment, he thought that the rabbit had bitten him, but on quickly withdrawing his hand he discovered, to his horror, a snake (called by the Mwera tribe, namaragwe, and by the Angoni, nambaco) clinging to his finger. Within half an hour the poor fellow was dead! The abovementioned snake has a very black skin, and is found chiefly in trees and among rocks. Many natives, usually when out in the forest searching for honey, are killed by it, and Simba, my tracker, tells me that one of this species accounted for Fundi Juma, who was one of the most famous native elephant hunters in German East Africa.

Two years ago, when encamped near Chimbunga's village, close to the Mbemcuru River, I had missed several fowls from my fowl-house, and suspecting my 
natives of having stolen them for food, accused them of the theft. They stoutly denied the charge, and when my cook brought me several half-eaten onions from my store, I came to the conclusion that some animal or other had been the cunning marauder in both cases. The tooth-marks on the onions, however, were strange to me, but the natives were positive in their assertions that the indentations had been made by a snake. Curiously enough, some days later, I happened to be rummaging in my store, where I kept all my provisions and ivory, and chanced to pull out from among the other goods a large tusk, measuring some eight feet in length. Now the root of every tusk is hollow, and in this particular one the cavity was about two feet six inches long and about seven inches in diameter. Immediately I pulled it free from the stack, a snake, some seven feet in length, shot out of the hollow end of the tusk and slipped out of sight among the pile of packages. Calling my men together, I told them to prod with their sticks among the wares, and ere long they drove the reptile out into the open, where they beat it to death.

The skin of this serpent, which the Angoni call lepinganombie, the Mwera, lebomah, was of a dark mottled grey colour. This particular species is most deadly and accounts for numbers of the natives' cattle and goats. 
While we were at the same camp at Chimbunga's village, a native woman left the kraal to visit another village some miles distant, carrying on her head a majamanda, or native basket, and on her back, tied securely to her, her little child. As she threaded her way along the path that wound through the forest, her child suddenly gave vent to a pained cry, but comforting the mite, and unaware of what had happened, the mother continued on her way, and only discovered on arriving at her destination that her babe was dead. On the top of the infant's head, the flesh of which was all swollen up, were the indentations made by a snake's fangs.

Several natives of Chimbunga's village had been killed at this identical spot, doubtless by the same snake, and strangely enough, some weeks after the unhappy incident narrated above, when I was travelling along the same path on the way to a distant village, where an elephant had been plundering the native shambas, my trackers pointed out to me a large snake coiled round a branch overhanging the path. I blew the reptile's head off with a shot gun and down came the writhing body across the path. It proved to be a fine specimen (about nine feet in length) of the nakahungu, a dull greenish serpent with an exceptionally large head, a species which is usually found in rocky, hilly places and feeds on small game, such as rabbits, birds, etc. 
The natives all say that the nakahungu is the largest poisonous snake in Africa with the exception of the dreaded songwe.

Among all the tribes of Eastern and Central Africa with whom I have come in contact, I have heard amazing stories of a snake called the songwe which, the natives most positively assert, has a red comb like a cock's on its head and crows in the same manner as that bird. They allege that the songwe deliberately waits on frequented paths for human beings and kills them, and some of my men stoutly affirm that they have been pursued by this reptile, though I, myself, have never encountered it, in spite of the fact that $I$ have been in all kinds of country where snakes abound. I have even offered a reward to any native bringing me this redoubtable serpent, either dead or alive, but this reward has never been claimed. I am, therefore, inclined to think, though I will not positively state, that the songwe lives only in their imaginations, and Simba, my tracker, who is a man of very sceptical and rational mind, says he believes it to be a fabulous snake, or probably the above-mentioned nakahungu, enlarged upon by those who have been scared by it.

When encamped near the Lumasuli River, some time ago, the path leading from my camp to the actual hunting-ground passed through a village some five miles distant, and on the path between my camp 
and this village several natives had been killed by snakes. On two occasions, when travelling along this route, we encountered a large snake, sunning itself in the middle of the way, which on our approach immediately sought shelter in a convenient hole. On the second occasion, we securely closed up the entrance with sticks so that the reptile couldn't possibly escape, and as we heard of no further casualties among the natives of the village, we inferred that we had taken ample vengeance for those poor fellows whom the reptile had killed. The snake in question was one of a deadly poisonous species, called, by the Angoni, najika, and by the Mwera, kolapongu. The skin is of a greyish tint with three black stripes on its neck, and the reptile attains a maximum length of nine feet.

There is a beautiful non-poisonous snake in the pori, called by the Angoni, ulalu, and by the Mwera, naru, which has a white skin marked with three longitudinal blood-red stripes, and to meet it, when hunting, is considered a most auspicious omen.

Very occasionally, I have encountered a large black, spotted snake, called by the Angoni, gulalahie, which is extremely poisonous, but not at all vicious, and which is generally found in the vicinity of ant-hills.

On one occasion, when we were hurrying along on the spoor of elephants which had bolted, a small 
black and white snake suddenly sprang out of the grass bordering the track and bit one of my men in the hip. As my man was of more importance to me than elephants, I immediately gave up the pursuit and, opening up his wound with a sharp pen-knife to let the blood flow, injected permanganate of potash all around the bite with a hypodermic syringe that I always carry on my person for such occasions. Though incapacitated for some days, the man completely recovered from the effects of the poison. This snake is called, by the Angoni, uwanjah, and by the Mwera, cheringulabunda. It is a small, hooded snake, varying in length from eighteen inches to two feet, and is extremely venomous, the natives saying that, unless the bite is treated, death occurs within an hour or so.

There is a species of African snake, about eighteen inches in length and of the thickness of a man's middle finger, which somewhat resembles a puff-adder in appearance and is called iperi tonga. It is most venomous, and if you come upon it by chance in the path, it will not attempt to escape, like the ordinary snake, but will show fight. The puffadder, on the other hand, is not aggressive unless disturbed or accidentally trodden upon, and often gives warning of its presence by a hissing sound not unlike that made by a gander.

In addition to the above-mentioned snakes, I 
frequently come across the black mamba and green mamba, both very deadly and vicious snakes. The black mamba is called, by the Angoni, duguwaloh, by the Mwera, letaebo; the green mamba is known to the Angoni as the jokomahamba, to the Mwera, as the namabamba.

As far as I can gather, practically the only effectual antidote to snake poison known to the natives is the root of a very small shrub called the cherungu. The root is pulverized, and some of the powder is taken internally with water, while some is rubbed into the actual wound.

While on the subject of snakes, which are, perhaps, of all living things the most repulsive to man, I must make mention of a dreadful little animal, which the natives are very averse to tackling. It is about the size of a badger, is covered with coarse, greyish-black hair, and has a white patch on the back. The Angoni call the beast mculae or chembulae, the Mwera, nculie. The extraordinary feature about this animal is its habit of springing at game and fastening on to its victim's testicles with its teeth. Some years ago, I shot a koodoo and found its testicles completely eaten away, and the natives stoutly asserted that this had been the work of the mculae, and averred that they had come across innumerable instances of an exactly similar kind. 


\section{CHAPTER XV}

WHERE A MAN CAN RAISE A THIRST

The dry season, which, in Equatorial East Africa, roughly extends from April to December, though favourable for hunting, owing to the comparative sparseness of foliage in the bush and the decay of the giant grasses which afford such excellent cover for all kinds of game, is often rendered by the terrible scarcity of water a most trying time. Only he who has lived the strenuous life of a hunter and seen the conditions that exist during a period of exceptional drought in that Continent of the Sun, can justly estimate the preciousness of this element which, when in the form of rain, is so often looked upon by those living in northern climes as an unmitigated nuisance. Picture to yourself a landscape held in the grip of a pitiless, blinding sunshine, the trees denuded of green foliage, the grass sere and yellow, and at times stretches of country, varying in extent from ten to thirty miles, without a drop of water. Imagine tramping all day long 
through such tracts; in some places the air full of the spores or irritating spicules blown or shaken from the seed vessels of withered vegetation; your shirt and trousers soaked with perspiration; arms, face, and neck baked in the torrid glare, and not a mouthful of water to slake the terrible thirst induced by such circumstances! The picture is not an inviting one, and yet the trying ordeal of thirst is one frequently suffered in greater or less degree by the elephant hunter and his men.

The dry season of 1909 was an exceptional one, adding to my experiences one that I shall not readily forget, and the narration of it may conjure up more fully before the reader's imagination the picture I should like to convey.

Shortly after leaving camp, we came upon the fresh spoor of four elephants and followed it, but our quarry, winding us as we drew near, made off at top speed to a country in which there were only two or three water-holes, scattered at wide intervals in absolutely trackless forest. Under the circumstances, I called a halt about 9 a.m., and instructed my carriers to make for a water-hole some nine miles distant, and await us there. At about I I o'clock, after two hours' steady spooring across peculiarly trying country, I got my boy to empty one of my water-bottles and make tea for me, while the contents of the remaining bottles I gave my 
men to drink. Feeling considerably refreshed, we once more resumed our pursuit of the elephants, but though we followed the spoor without resting, they succeeded in keeping a safe distance ahead of us until nightfall compelled us to give up the chase. Keen as was our disappointment on the score of a fruitless hunt, our failure to discover water was a matter of much more serious import, and as darkness precluded any further search in that direction, we pitched camp. We now began to experience the insistent pangs of thirst, and the silence that suffering entails reigned over our little camp. There was none of the chatter and laughter inseparable from healthy, careless men, leading free and open-air lives, and as nought was to be gained by discussing the subject of our discomfort, I turned in, only to be visited in my sleep by all sorts of Tantalus-dreams, in which iced champagne, hock and seltzer, and tankards of cool beer engaged in a veritable devil-dance just beyond my reach.

Next morning, deeming that the elephants we had pursued were many miles away, we decided to return to the water-hole whither our carriers had gone the previous day. Hardly had we been an hour on our journey, when Fate, as if in a wilfully malignant mood, brought us across the fresh spoor of three large bull elephants (the foot-prints of 
females are much smaller than those of their mates). Parched with thirst though we were, the temptation to give chase was irresistible, and only a hunter who has lived by his rifle knows the power of that allurement. So we turned aside, trusting that the hunt might be brief and fortunate, and assisted in our decision by the knowledge that our quarry would in all probability lead us to water, even should we fail to get a shot at them. On both counts, however, we were doomed to bitter disappointment, for, after following them till about eleven o'clock, we discovered, to our intense chagrin, that they had joined a large herd of females, a fact which renders killing them a matter of great difficulty and increased danger. To 'put the lid' on matters, they got a whiff of our tainted air and the whole herd decamped! Where the males had joined the females, we came across some water-holes, and you can imagine our feelings of disgust when we found that these were bone-dry!

We had not partaken of food or drink since the previous morning, and all day long we had been marching under a merciless, blistering sun, during the hottest month of the year, Hunger, however, was a minor matter in comparison with thirst, and even during the intense excitement of the hunt, at the back of our minds there had been the persistent craving for water. Water! water! water! the 
words had seemed to beat in a rhythm of pain with the tramp of our feet, and it was only by a supreme effort of will that we had forced ourselves along, every step a torturing tax on our flagging energies. And now we had to return! We roughly computed that, in a direct line, we were about six hours' journey from where my men were encamped, and knew that only by ceaseless, hard tramping could we hope to reach them before evening. The situation was not one to ponder on at leisure; there was nothing left to do but make a start, and that at once!

About 2 o'clock in the afternoon, Malingum, my tracker, the lines of whose face were drawn with suffering, told me that he was completely exhausted and would rather stay where he was and run the risk of dying than go on any further in the sweltering heat, and Usufu, my boy, in a similar state of collapse, decided to throw in his lot with Malingum. My other tracker, Hyiah, and my cook seemed in better fettle, so leaving the latter to take care of the 'played outs,' and depositing all our ammunition, save twenty cartridges each, in his charge, Hyiah and I resumed our heart-breaking journey, bidding the three be of good cheer until we returned with water. On we foot-slogged-there is no other word for itmaking a bee-line for our camp, and taking care to blaze the trees as we went, so that we should lose no 
I52 ADVEN'TURES OF AN ELEPHANT HUNTER cH.

time on our return journey with the life-giving water. By this time, our thirst was too painful to describe, and Hyiah having reached such a stage of weakness that he could no longer bear the weight of my

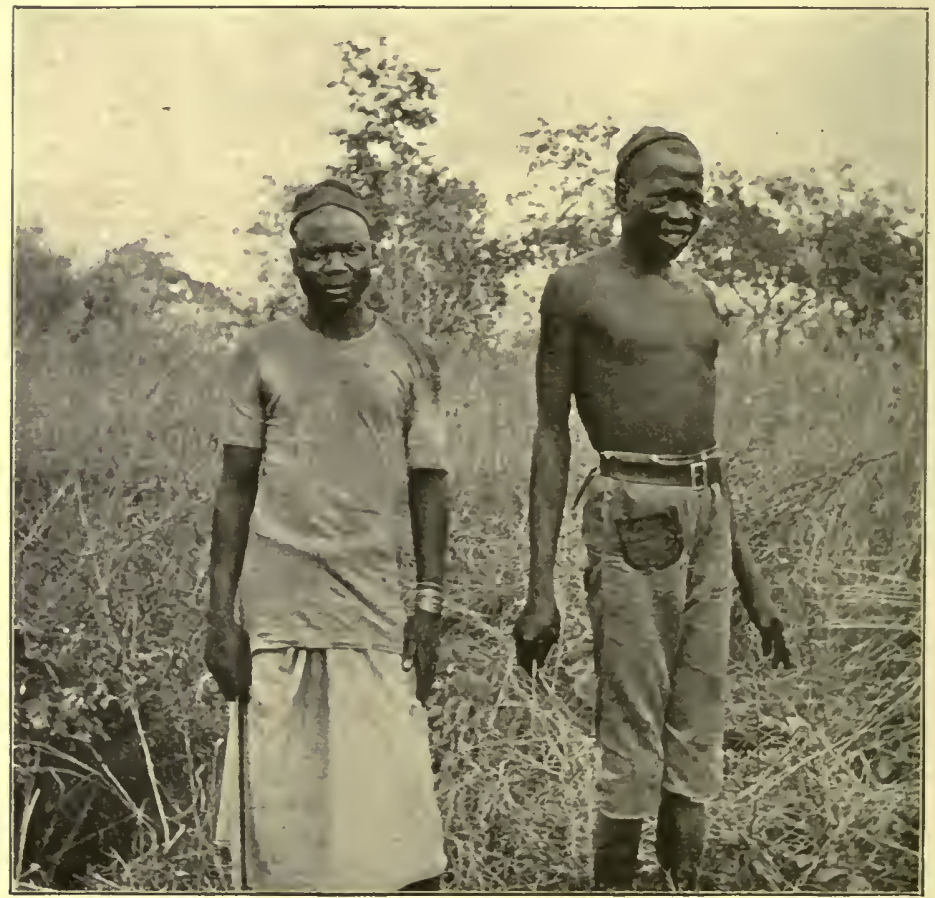

USUFU AND MALINGUM.

heavy rifle, we hid the weapon under a shrub and marked the spot so that we could easily find it on our return. Relieved of his burden, Hyiah managed to stagger on behind me, but he was walking mechanically and was so exhausted that I feared he 
might collapse at any moment. Inured though I am to hardship, the terrible strain was beginning to tell on me so much, that the desire to fling myself down and await the cool of evening became wellnigh irresistible. My tongue swelled up and stuck to the roof of my mouth, my lips were cracked and bleeding with the dry heat, even my light rifle seemed to have acquired the weight of a heavy baulk of timber, but the absolute necessity of a weapon of defence, in case of untoward circumstances, precluded any idea of leaving it behind. Moreover, the axe with which I was blazing the trees seemed to grow in weight as my strength failed, and the effort to wield it became so painful that, once or twice, I almost decided to desist, speciously arguing that a rest would freshen me and enable me to reach camp. But apart from feeling that it would be disastrous to show any weakness before my tracker, Hyiah, who, to prove himself a man, was simply dragging himself along, every muscle drawn in acute suffering; the thought of my men behind me, dying of thirst and awaiting my return as their only hope of salvation, gave me strength and courage to totter on. I also reflected on those gentle and refined beings who treasure the baubles so wondrously carved and wrought from the beautiful white stuff the quest of which had landed me in my predicament, and wondered 
if they ever pondered on the risks and hardships endured by those who sought the raw material. What a far cry from the delicate objet d'art in some dainty boudoir to the thirst-crazy hunter wandering in primeval forest !

On, on we trudged, and as the sun sank on the horizon like a globe of cooling iron, a large ant-hill loomed ahead of us, and towards it we dragged ourselves with painful steps. On reaching it, Hyiah managed to crawl up it on hands and knees, and simply stretching forth his hand and muttering the one word 'Bwana,' lurched forward on his face, utterly exhausted. Coming up to where he lay, I saw wreaths of smoke ascending about half a mile away and knew they must be rising from the campfires of my men. Dropping the axe, I fired our usual signal, four rifle-shots in quick succession, and threw myself down beside my tracker. After a few minutes of keen suspense, I could distinguish the voices of my men who, on hearing the reports of my rifle, had at once set forth in search of us. Too weak to shout in reply, I fired three more shots to guide them to where we lay, and shortly afterwards, to our intense relief, my boy Konyaki and three carriers arrived on the scene, bearing a couple of small calabashes of water and a bottle of whisky. Never were whisky and water more welcome! Pouring a little of the spirit into the palm of my 
hand, and diluting it with water, I emptied it into Hyiah's mouth as he lay, and, immediately afterwards, treated myself to a similar dose. After the lapse of a brief interval, I gave him a few sips of water from one of the calabashes, taking particular care that he should not, in his extremity, greedily swallow a considerable quantity of the liquid. In another ten minutes, I handed him the calabash to drink his fill, while I myself did ample justice to the other. No gods ever brewed a nectar half so delicious as that long draught of water! I have often thought since that occurrence how fortunate it is that the reason can control the pressing demands of the physical being, for had we in our eagerness gulped down the water without restraint, the results would, in all probability, have proved disastrous.

As Konyaki and the three carriers had brought no food with them and barely enough water to satisfy Hyiah and myself, I had to dispatch them back to camp and await their return with further supplies before we could set out to succour the men whom we had left behind. After about an hour's rest, during which we disposed of large quantities of tea, supplemented with plenty of sugar-we were too exhausted to eat-we started off. Fortunately, the moon was in its third quarter and illumined the forest sufficiently to enable us to track our way by the blażed trees, yet, owing to the uncertain light and 
the necessity of taking repeated rests on account of our weak condition, we only reached our men about eight o'clock next morning.

They were lying under the shade of a dense shrub, Malingum and Usufu being in a very low state, the cook in somewhat fitter condition. After putting them through a process of revival similar to that to which we had subjected ourselves, we all lay down for a couple of hours' rest in the same convenient shelter, and at the end of that time we felt strong enough to partake of food. Our repast over, we set out and, travelling at a moderate rate, arrived in camp late the same evening. Next day, we did little else than eat and sleep, and, owing to the fine physical condition in which we always were, experienced no prejudicial effects from our trying adventure. 


\section{CHAPTER XVI}

BIG GAME AND BIG GAME HUNTING

Generally speaking, throughout Africa, the best time for hunting, especially elephant hunting, is towards the end of the dry season, and when the early rains have begun. In German and Portuguese East Africa, where I have spent most of my hunting days, this period extends from September to the end of January. I have always shot more elephants, in the four months, September, October, November, and December, than in the remaining eight months put together, although I shoot steadily all the year round. Various causes conduce to this result. In the first place, most of the small pools and tributary streams are dry, and water can only be obtained at main streams and odd water-holes, so that elephants, who during the previous months roam all over the country, now perforce congregate within these areas; also, the heat being more intense during the four months above mentioned, the quarry tires 
much more quickly in the chase than during the cooler seasons.

In the rainy season (which usually extends from December until March), and, in fact, right on to the end of June, elephant hunting is beset with more difficulties and dangers. The giant grass, which grows rankly during the rains and attains its maximum height ere the end of March, offers almost impenetrable cover to all big game, until it is somewhat levelled by the action of sun and wind and the trampling of beasts, towards the end of May and beginning of June, when the natives start firing the bush. Besides, during the first six months of the year, all wild animals consort more together, and it is often extremely difficult, when hunting, to select the males from the females in the riotous luxuriance of the bush foliage, and especially in the tall, reedy grass which elephants love to frequent.

With regard to big game hunting, especially that of elephants, I have at various times read, in books written by sportsmen, statements which are at variance with my experience. Some of these statements have passed unchallenged into the general currency of our everyday knowledge of the habits of the denizens of the wild. As I have spent so many years in what I might call close touch with these creatures and have had unique opportunities of ob- 


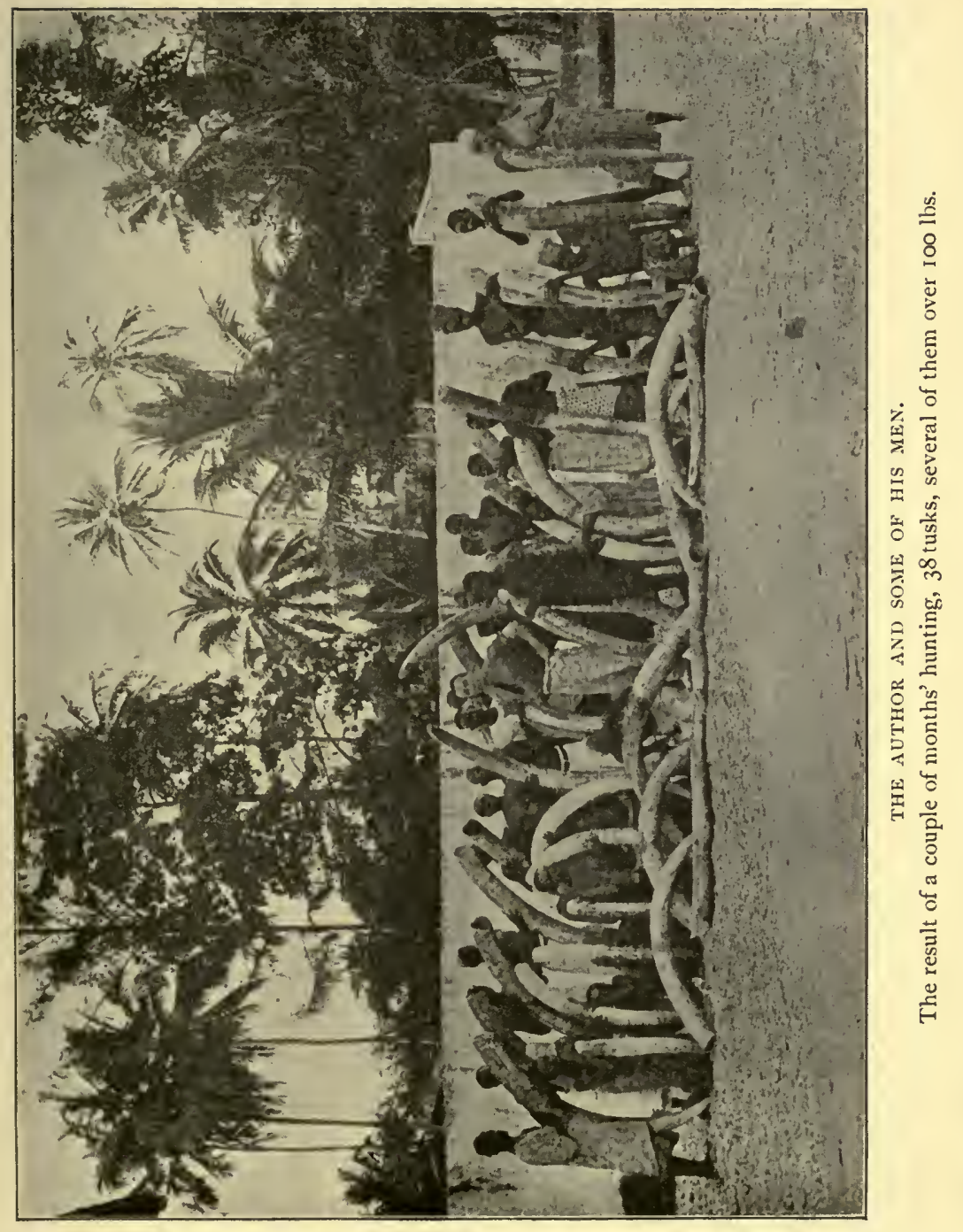


serving them in their natural habitat, I feel that my opinion will carry some weight with those competent to judge. I should like to state that I express such opinions, not out of a wanton love of contradiction, but simply with a desire to tell the truth, the whole truth, and nothing but the truth, and thereby remove flagrantly erroneous conceptions from the minds of those interested in such matters.

Some time ago, I read in a book on big game hunting that, in our sense of the word, an elephant never rests and that, except in water, he cannot lie down on his side, but stands on three legs, swinging the fourth. I cannot imagine on what basis the writer makes such a statement. My considerable experience of elephants has taught me the contrary. On numerous occasions, I have come across elephants lying down, and one of the illustrations in this book depicts an elephant I shot while he was lying sleeping. No doubt the shooting of a sleeping elephant may seem unsportsmanlike to the reader, and I can assure him that my feelings in the matter do not differ from his, but it must be remembered that I was simply in quest of ivory as a means of obtaining a livelihood, and that, under such circumstances, scruples have to be brushed aside. I hardly think that any man on a similar occasion would politely wake the elephant before shooting him, and my action in the case is absolutely on 
a par with the taking of a bullock's life for food.

At the Rovuma River, in 1906, I came across a female elephant and her calf, both lying down, and I managed to approach within twenty yards of

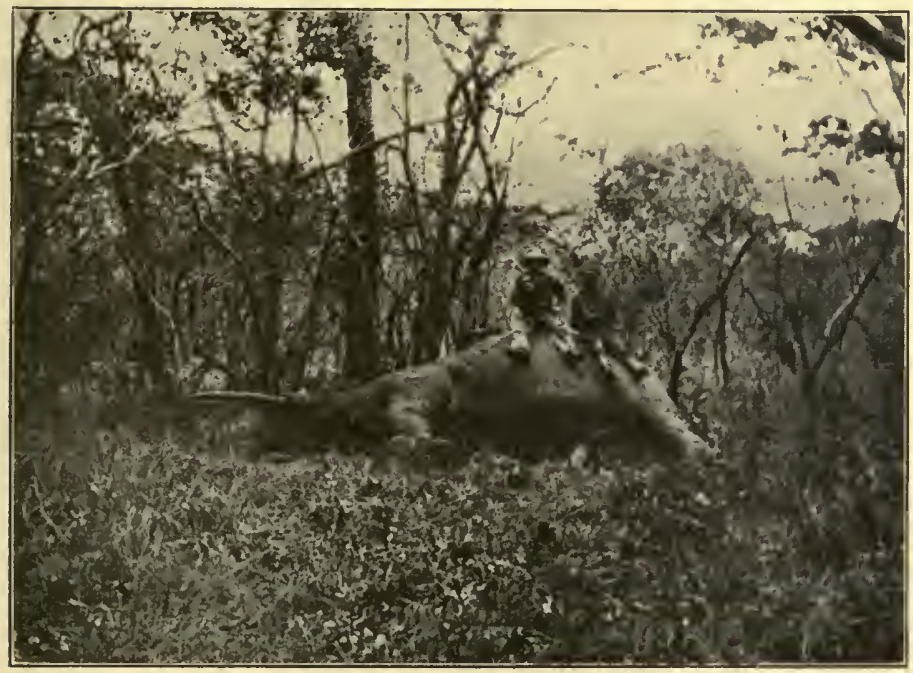

ELEPHANT SHOT WHILST SLEEPING,

them before they saw me, when they simply jumped up and bolted.

In October, 1907, one morning at dawn, we chanced upon the spoor of three male elephants, and at eleven o'clock came up with them at a spot where they had just been feeding. The largest of the trio, whose tusks weighed 74 and 77 lbs., respectively, was lying down at full length with his forelegs curled under him, while his companions were standing 
beside him. On my approach, the recumbent one, evidently having heard us, lifted his head and at that moment I fired, putting a bullet through his brain. Then I shot the remaining two.

At the Bangalla River, in 1908, I had followed up the spoor of four big males, and, coming up with them, found one of their number lying down asleep, while his companions stood beside him. Having approached under cover of a large ant-hill to within twenty yards of the herd, I had a perfect view of the sleeping tusker, who was lying on his left side with his head resting on its side and his feet extended at right angles to his body. I sent a single bullet from my 577 axite rifle through his brain, and he never budged from his original position, save for a few spasmodic kicks with his legs. Of the remaining three, I had the good fortune to pick off two as they were making off.

Very many other instances of elephants lying down on their sides have come under my notice, but I feel sure that those cited will serve to explode the ridiculous theory mentioned above.

In addition, I may perhaps state that again and again elephants, whom I have wounded in the vicinity of the brain, have fallen and pro tem. lain on their sides, but if not finished off, have eventually risen and got away.

Finally though the elephant appears to be a big 
and ungainly creature, he is by no means so awkward as his size might lead one to believe. For a short distance, he can run at a great pace, while jumping ditches is for him a matter of comparative ease. In short, his strength is in proportion to his bulk, and he is admirably adapted to the nature of the country in which he lives.

With regard to the risk attendant on hunting various kinds of big game, (a subject on which many famous hunters hold very diverse views,) all my experience tends to confirm me in the opinion that the pursuit of the elephant is, without doubt, the most dangerous. Second, and on a par, I would classify buffaloes and lions; third, leopards. In comparison with these, very little risk attaches to the hunting of the rhinoceros. However, in any such classification, so much depends on the manner of hunting; for it is obvious that to hunt alone, with one or two natives as trackers, is accompanied by considerably more danger, than to form one of a party armed to the teeth with powerful modern rifles. And when an old hunter chances, in his reading, to come across an account of three white men all helping each other to kill one poor lion, he feels his gorge rise and, after making every possible allowance for the state of modern civilized nerves, is disgusted to think that such a wretched farce should masquerade under the name of sport. Nor can that 
term be generously applied to the hunting down of lions with dogs, for, while the lion's attention is occupied with his canine opponents, to shoot him is a matter 'of comparative ease and attended with very little risk.

Lion-hunting entails a considerable amount of risk when a wounded animal seeks cover in long grass or dense bush, and the hunter follows his quarry on foot with only his tracker carrying a spare rifle. This requires a combination of nerve and cunning and is excellent sport. The same may be said of buffaloes and, in a greater degree, of elephants.

It is my opinion that the risk attached to the shooting of the rhinoceros is very small, for he lacks the intelligence and cunning of the aforementioned animals, and, though I have shot scores of them, on no occasion has one charged me.

The hunting of the hippopotamus is the very tamest of sports, and even when shooting from a native canoe, the hunter is comparatively safe, for in ninety-nine cases out of a hundred the beast, when wounded, will make every effort to escape without showing fight.

Taking all smaller game into consideration, I cannot say that their pursuit is fraught with much peril to the sportsman. Quite recently, I have read what I can only term as somewhat hysterical accounts 
of hunters being charged by roan and sable antelopes, and of the redoubtable and vicious fighting character of the bushbuck, which, so says one account, will charge a man without hesitation. In all my hunting career, and I have shot dozens of the three last-

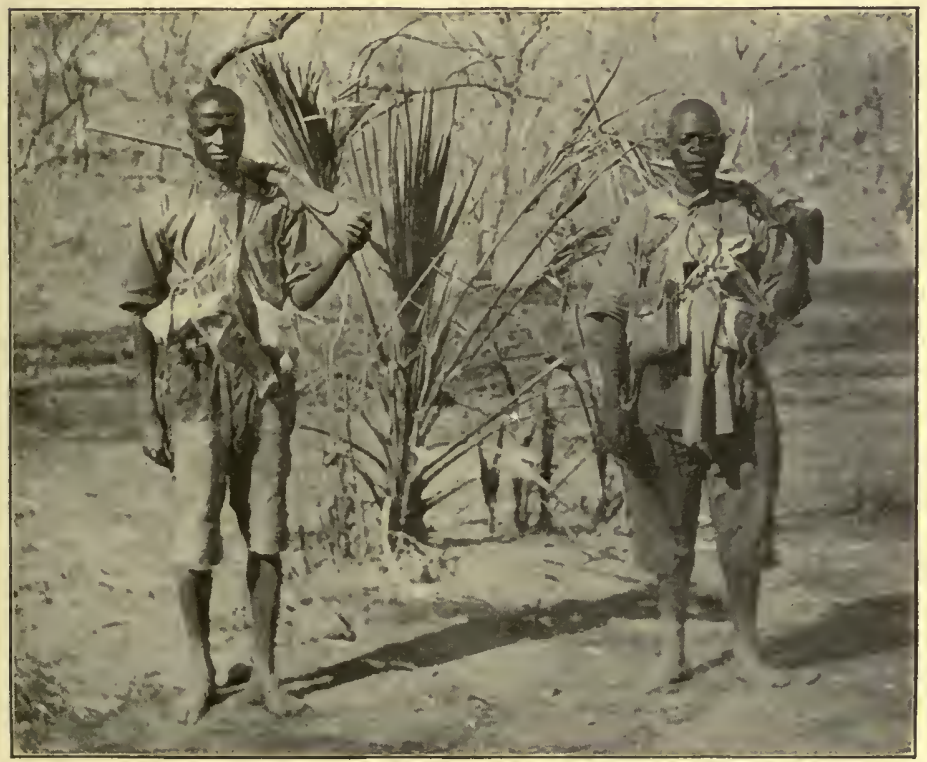

MY TWO TRACKERS. SIMBA (ON LEFT), TUMBO (ON RIGHT).

mentioned game, on no occasion have I ever been charged by any of them.

Almost any wounded animal, when you approach him, will instinctively endeavour to defend himself, and the statement would apply to the ordinary billygoat at home; but to class any of these antelopes as dangerous is, in my opinion, purely and simply 
a misrepresentation of facts. Only the very inexperienced hunter could possibly misconstrue this simple defensive action of a wounded animal into a threat of mischief, and I feel sure that many a blind rush to escape the danger at hand, which chanced to come in the direction of the hunter, has been mistaken for a wilful and vicious charge.

I should like, at this point, to discountenance the assertion made by many writers and believed by the general public at large, that all kinds of African big game-especially elephants--are being swiftly and surely exterminated. They who make such sweeping statements most certainly know little about the subject, and probably draw their conclusions from the insufficient data that they acquire by following the beaten track. In the Congo State, in German East Africa, in Portuguese East Africa, in British East Africa, and in Uganda there are, 'quite apart from innumerable game reservations, thousands of square miles of quite uninhabited country in which there are hundreds of thousands of elephants and of every other kind of game, with the exception, perhaps, of giraffes.

Taking into consideration the laws promulgated during the last few years by all civilized countries for the preservation of big game within their African possessions, instead of any risk of exter- 
mination, there seems a probability of a decided increase in the numbers of such game. Such an increase, let me say, would prove a serious calamity, for it would give a great impetus to the propagation of the deadly tse-tse fly, which follows big game and breeds in their dung. This pest, as is well known, means death to all domestic animals, and thus renders uninhabitable by Europeans vast tracts of country which would otherwise make admirable colonizing grounds. The matter reduces itself to the simple question-is Africa going to serve as a colony for surplus European populations, or as a collection of big game reserves ?

On the subject of bodily hygiene and of a dietary suitable for the tropics, a great deal has been written. Naturally, in such matters individuals differ; one man's food is another man's poison. My personal experience differs somewhat from the usual and may prove interesting, if not useful, to those intending to pass any considerable time in these regions. Firstly, with regard to baths, I have never departed from the good old-fashioned cold tub and rub down, preceded by exercise on rising, while in the evening, I wash down thoroughly with soap and hot water and finish off with a cold douche. Before retiring, I always rub myself all over with cocoa-nut oil to keep my skin in perfect condition. 
With regard to the question of food and beverages, first thing in the morning, I drink a cup of cocoa; after my bath, I have a cup of perfectly made tea with a couple of biscuits. When in camp,

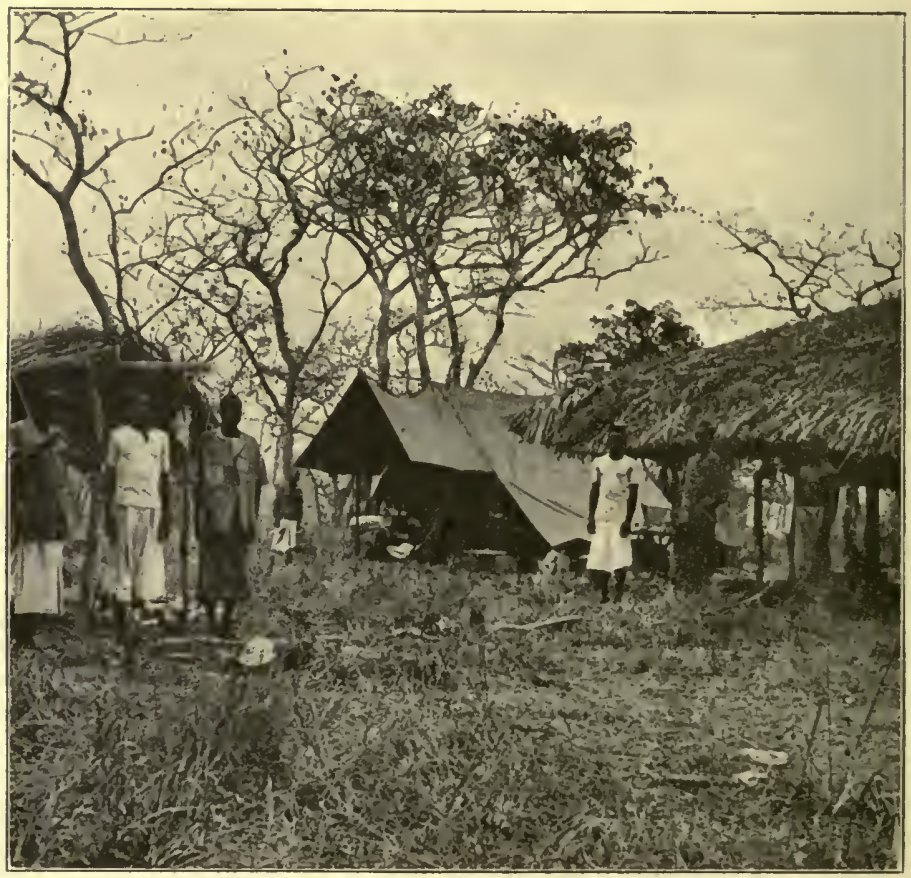

MY TENT AND HANDA WITH PRIVATE SERVANTS.

lunch and dinner differ little from the same meals in the Old Country, though often supplemented with a thick porridge made from native matama flour. Vegetables consist of onions and of herbs found in the forest, several species of which are almost identical with spinach. Mahometan cooks, 
being past-masters in the art of serving up a perfect curry, cooking a fowl, or roasting a joint of buck, civilization has few advantages to offer in the matter of food. On safari, and when tracking elephants, as time does not permit of the cooking of a solid meal, I have to be contented with picnic fare, and I find that during a spell of strenuous work there is nothing so energizing as a mixture of cocoa and sugar taken at intervals. In the evening, when I have finished my day's work and bathed, I always indulge in a stiff whisky and soda; with dinner, I regularly consume half a bottle of port wine (it really is port wine), and ere retiring to bed another strong peg or two of whisky. For a few months' hunting, it is quite immaterial what one eats or drinks, but I find that, to endure month in month out, year in year out, the arduous work and strain of elephant hunting in a hot and enervating climate, a considerable quantity of alcohol is absolutely essential to my physical wellbeing, and seems to help in the assimilation of my food and give me refreshing sleep at night. Of course, during actual work and in the heat of the day, alcohol is certainly prejudicial, and when in a temperate climate I feel little or no desire for stimulants in any shape or form. After years of this dietary and hard life, I feel in perfect physical condition, and a recent medical examination 
revealed that all my organs were sound and healthy.

A considerable supply of clothes, such as khaki shirts and trousers, and of light shoes for running in, is a necessity, and I find that very thin cotton vests, which I immediately change when soaked with perspiration, are the best. My boy carries two or three changes of these vests in a small waterproof wallet over his shoulder.

Perhaps, when discussing big game and big game hunting, a few remarks on rifles will not be out of place, but as the subject is naturally one open to endless discussion, I shall express a personal opinion rather than dogmatize. During my hunting career, I have used all kinds of rifles from the 4 bore, black powder, elephant rifle downwards, but as the black powder rifle is a thing of the past, I shall confine my attention to modern high-velocity, smokeless powder rifles, which are infinitely superior to their predecessors on account of their greater range, velocity, power and lightness.

In the first place, the man behind the rifle is so obviously of primary importance that the fact may be dismissed without further comment, while the great consideration in all hunting is to kill and not merely to wound the game fired at. With regard to the weapon, practically any modern rifle will kill game if the bullet penetrates a vital part such as the 
brain, heart or vertebræ, but under ordinary conditions, such as dense cover with sharp contrasts of light and shade, these shots are difficult, and what is requisite is a rifle with a flat trajectory, which will, should a vital spot be missed, deliver a smashing, disabling blow.

With a 303 , I have killed all kinds of game from elephants downwards, but it must be remembered that the hunter who uses a weapon of such calibre against large and dangerous game at close quarters in bush country, runs considerable risk of losing his life, for the bullet has neither the requisite weight nor velocity always to prove thoroughly effectual. And with regard to their use against smaller game, though such light bullets have great penetration, they do not administer a sufficiently paralysing blow to prevent a wounded animal from bolting and thereby obliging the hunter to pursue his quarry for miles, with a chance of losing it altogether and leaving it to die a lingering death in the bush. My experience has, therefore, taught me to consider the 303 a thoroughly unsuitable and unsportsmanlike weapon, the use of which should most emphatically be discontinued. For all kinds of game, save rhinoceroses and elephants, my ideal rifle is one that fires a bullet, lead-nosed or copper-capped, weighing between 350 and 400 grains, and leaving the muzzle with a velocity of $2,300 \mathrm{ft}$. or more 
172 ADVENTURES OF AN ELEPHANT HUNTER cH.

per second; for the simple reason that such a bullet expands, tears a large hole and spends all its energy in the animal without slipping through.

Against small game, I have for some years used a 3 i 8 rifle and find it, especially in conjunction with Westley Richards patent copper-capped bullets, immeasurably superior to either the $\cdot 256$

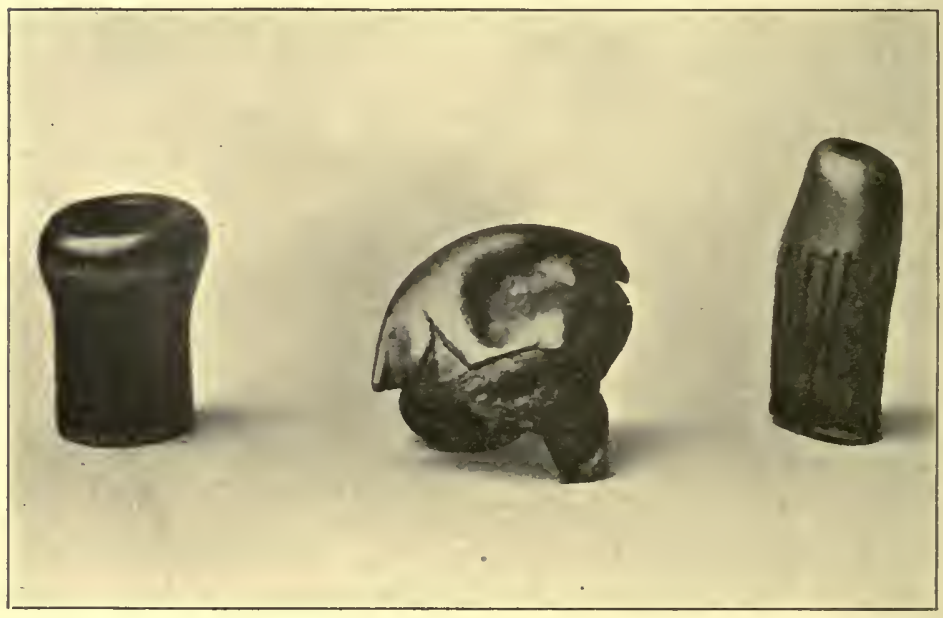

577 BULlet SHOWING IDEAL CAPPING; 577 BULLET (IN CENTRE) SHOWING IDEAL MUSHROOMING; ON RIGHT, 500 SOLID NICKEL COVERED BULLET.

or 303 , and one which has, on account of its high velocity and ideal form of expanding bullet, all the advantages of long range and flat trajectory associated with the small bore, and a large amount of the shock-giving qualities obtained with a larger bore rifle, without the recoil inseparable from that weapon. 
The elephant and rhinoceros, being in a class by themselves, require a rifle firing a much heavier bullet. After experimenting with and using all kinds of rifles, I find the most effective to be the double 577 with a 750 grains bullet and a charge in axite powder equivalent to a hundred grains of

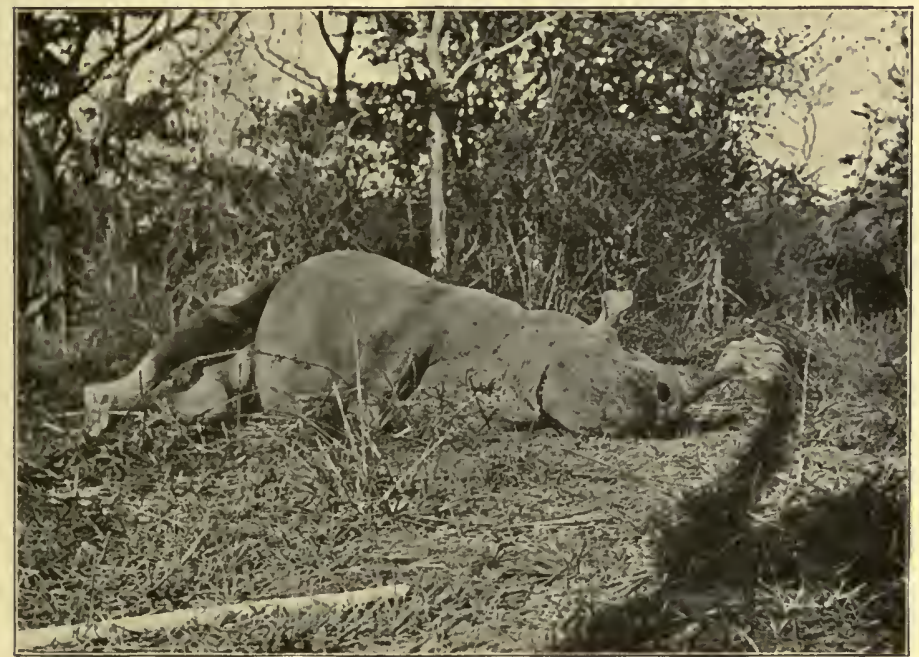

RHINOCEROS.

cordite. The heavier double-barrelled 600 bore rifle, with a bullet weighing 900 grains, lacks the penetration of the 577 , while its weight ( 6 lbs. against $13 \mathrm{lbs}$. of the latter) renders it a much more awkward weapon to handle. I think the superiority of the 577 over the 450 and 500 rifles, will be evident when I state that I have lost elephants with these last two rifles, while I have bagged 
others with identically the same shots from a 577.

When using double-barrelled rifles against big and dangerous game, it is of supreme importance to have a thoroughly reliable ejecting mechanism, and I find that a single trigger is a vast improvement on the old double-trigger, for, apart from eliminating the risk of a bruised finger, the single trigger is infinitely quicker, enabling a double shot to be placed almost simultaneously, if necessary. I have used the single trigger for some years and would on no account go back to the double. Another factor to be considered with regard to a rifle for big game is the length of the barrels. It is my opinion that they should be as short as possible, certainly not longer than twenty-six inches; for a rifle with barrels exceeding this length is extremely awkward to manipulate in bush country. The doublebarrelled 577 which I have used for several years and found admirable in every detail was built for me by Westley Richards \& Co., of Bond Street. The construction of the locks is excellent and simple to a degree, so that should anything go wrong with the mechanism in the bush, where you cannot take a taxi to your gunmaker, there is no difficulty in instantly detaching a lock by hand and replacing it with a duplicate. The single trigger and ejector attached to this rifle have on no occasion failed to act. 
In open country, against elephants and rhinoceroses, where the quarry is difficult to approach and long shots are often required, I find that I can do all that is requisite with a small bore rifle, such as the 318 , using, of course, solid nickelcovered bullets, for, owing to the easy manipulation afforded by such a weapon, a more deliberate aim can be taken than with a heavy rifle.

I have dwelt at some length on this subject of rifles, for I feel that the matter is one of importance, from the point of view not only of the hunter, but of the game. The point of view on which I insist is one of common humanity, and the young hunter should think deeply over the subject of weapons before going out against game with any small bore magazine rifle. For, as I have already said, the penetration of these rifles is great and the bullet so small, that an animal hit in any but a vital spot may escape to die in agony in the bush, while the sportsman, finding that he has not bagged his quarry, often indiscriminately empties his magazine into other animals of the herd, trusting to drop one or more out of the number. There is no censure strong enough for this reckless cruelty, and I feel that much of it would assuredly be avoided, if the hunter would only give the foregoing notes his careful consideration. 


\section{CHAPTER XVII}

\section{MALINGANIRO AND HIS IVORY}

Malinganiro, whose villages used, in the old days, to lie on the plateau close to the eastern shore of Lake Nyassa, within two or three days' journey of the Portuguese Collectorate at Matengula, was the least powerful of the three notorious chiefs, rulers over the turbulent and warlike Wyao tribe. (Since the date of the episode, which I am going to relate, his people have removed to the Awembe Mountains in Mataka's country, three or four days' journey further east, and are now under the headship of a descendant of the same name.) Up to 1900 , though Malinganiro had not openly acknowledged the supremacy of the Portuguese Government, and never allowed the Portuguese askaris (or native soldiers) to enter the district under his sway, no actual rupture had occurred. Stormy times, however, were ahead, for all the factors conducive to trouble were at hand.

In the first place, it was well-known that Malin- 
ganiro had accumulated a large quantity of ivory; for, apart from the fact that most of his men were elephant hunters, he had acquired a considerable portion of his stock of that precious commodity by plundering the villages on the lake shore. This knowledge was sufficient to rouse the cupidity of the Portuguese, but Fate required another piece in order to play the strangely malign little game that it had in its mind, and that piece was at hand. There lived at Matengula a thorough scoundrel, one Abdullah Nkwanda, a negro with a considerable admixture of Arab blood in his veins, who, for some years, had been trading in a small way in this part of the country, and he and the Portuguese were not long in putting their heads together and evolving a plan worthy of the occasion and the booty at stake.

Getting permission from Malinganiro, Abdullah took up a stock of goods to the chief's head village and announced his intention, were he properly treated, of making his home there. Malinganiro was delighted with the idea, and by way of giving an assurance of his friendliness towards the newcomer, sent Abdullah Nkwanda one of his daughters.

It did not take Abdullah long to satisfy himself that Malinganiro really had plenty of ivory, and, what was more important, was willing to dispose of it, and the only difficulty that stood in the way of 
good business was that he, Abdullah, had only a small stock of goods and none at all of what Malinganiro most desired-kegs of gunpowder. However, determined to overcome all obstacles, he promptly told Malinganiro that the Portuguese had plenty of this commodity at Matengula, but gave it out only to reliable chiefs on their personal attendance. As for goods, well, he, Abdullah, could procure plenty from English territory, but would not dare to bring so large a quantity so great a distance, and hinted that Malinganiro, himself, might not be above stealing them when they did arrive. To overcome the difficulty, therefore, Malinganiro, so suggested the wily Abdullah, should bring his ivory down to Matengula in person, and there receive the goods and gunpowder in exchange.

It must have taken considerable persuasion to induce Malinganiro to fall in with this plan, but he eventually did so, and arrived at Matengula in I90I, bringing with him about sixty loads of ivory. The Portuguese received him in good style, and, for a time, all went well-in fact, until bargaining for the ivory commenced. Then Malinganiro discovered, to his surprise, that no gunpowder was forthcoming, and as the price offered for his ivory was ridiculously low, announced his intention of taking his tusks into English territory and disposing of them there. Thereupon, the Portuguese politely informed 
him that if he wished to do this, he must first bring his ivory into the boma, have it weighed, and receive export papers made out in the latest European style. Suspecting nothing, Malinganiro took his ivory into the boma-only to find himself made a prisoner! Then the old and well-rehearsed farce was enacted once more: to save his life, Malinganiro was obliged openly to acknowledge the supremacy of the Portuguese, and on his submission was released, but his ivory was confiscated, or, as they tactfully put it, 'held as security for the good behaviour of himself and his people.' What Malinganiro thought of this delightful euphemism, it would be difficult to say, but from that hour until his death the Wyao chief made every effort to recompense the Portuguese for their kindness. Malinganiro became a name of terror to the dwellers on the lake shore; village after village was sacked and burnt; askaris were waylaid and killed; mutilation, torture, and death were meted out with impartiality to anyone connected with the Portuguese and their detestable rule.

My memories of Malinganiro are still vivid. He was a short, jolly, rotund man, who passed much of his time drinking beer and smoking bhangi-royal occupations in the eyes of a nativeand yet, in spite of his debauchery, there was about 
him that air of distinction which unmistakably denotes the chief. On two occasions I happened to pass through his village. On the first, I encamped just on the outskirts of his kraal, and he came down to meet me with a retinue of about seventy men, all armed with muzzle-loading rifles, to inquire what I was doing in his country, and whether I wasn't afraid to come there without his permission and with so few men. I replied that I was an Englishman, and had nothing to fear; that I had seven rifles, five of which had ten cartridges in each of them, and should trouble arise, each cartridge would mean at least one dead man. I assured him, however, that I was not there for fighting, but simply on my way to the Lujenda River, in search of elephants, and desired to purchase some food for my men and myself from his villagers, to which he replied that an Englishman was welcome to pass through his country, but that he would spill his last drop of blood in resisting the aggression of the Portuguese shensis (heathens). To show that I was desirous of being friendly, I gave him a cupful of whisky and a bowl of tea, and no sooner had he put these out of sight, than he begged for more. This I promised to let him have next day, and on returning to his village, he sent me fowls, eggs, and goats for myself, and plenty of flour and native beer for my men. 
On his death, the chief succeeding him adopted the name of Malinganiro, and has continued to carry out the policy laid down by his predecessor of murdering, enslaving, and pillaging, whenever the opportunity arises, down to this very day. 


\section{CHAPTER XVIII}

TERRIER v. ELEPHANT

In the depths of the heart, where I treasure the memories of the friends I have and of those I have had and are now no more, there is a soft spot which belongs to a little fox-terrier who was for some time a companion of mine through the storm and stress, the joys and sunshine of the lonely pori. $\mathrm{He}$ was not a thoroughbred terrier-merely a mongrel-but there are occasions when breeding is not everything. Whisky (for that was his name) was one of Nature's gentlemen. For affection, for sheer pluck, for that downright impertinence so characteristic of the terrier, this dear little fellow was hard to beat.

To say that a terrier would have the audacity to tackle an elephant seems so ridiculous that many will be inclined to think the story which follows something in the nature of fiction, but I can assure the reader that this is not so. Let me relate the incident exactly as it happened. 
During the forenoon of September I 5th, 1909, at Kitulika stream, a small tributary of the Mbarangandu, I shot a couple of fine, big tuskers, and the remaining one of the herd, decamping and progressing in a semi-circle, came across my carriers, who were following up about a mile

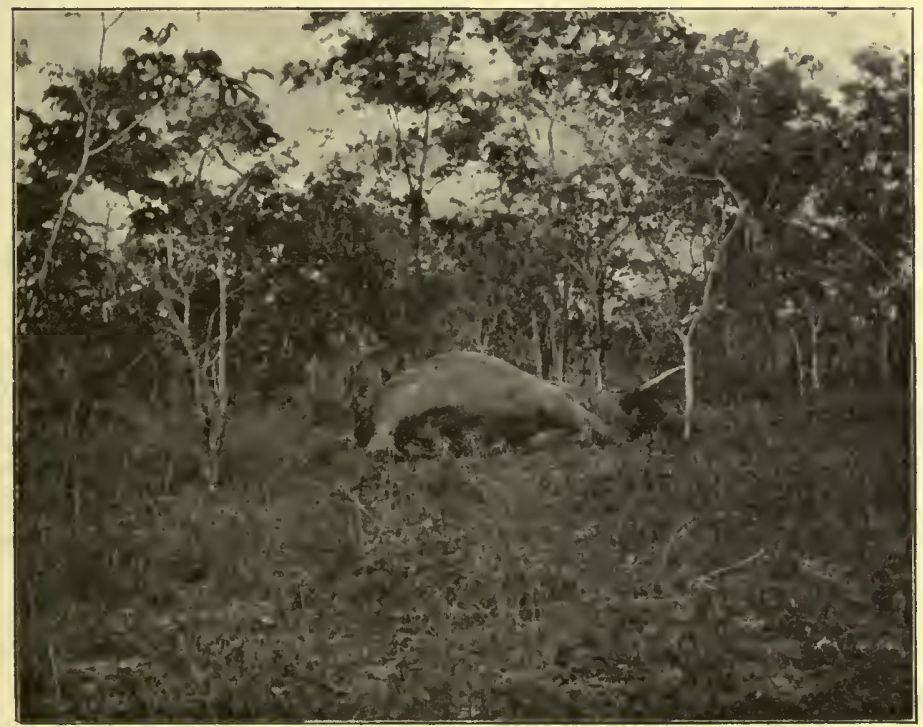

TWO TUSKERS. THE SECOND JUST DISCERNIBLE IN THE BACKGROUND.

behind. Getting their wind, he immediately turned back on his tracks, which I was following, and, all of a sudden, I heard him about a couple of hundred yards off, forging his way through a thicket of long grass and coming straight in my direction. As my trackers and I were standing in a patch of country free from vegetation, the grass having been 
burnt by native bush fires somewhat earlier in the year, I decided to wait and see if the animal would venture out of cover and give me an unobstructed field for shooting. A few seconds afterwards, he reached the verge of the long grass, about a hundred yards from where we lay expectant, so bidding my tracker Hyiah stay behind and take charge of Whisky, I gradually crept on hands and knees towards my quarry, Ntawasie, my second tracker, crawling stealthily in my wake with my light rifle. The elephant, who, I could see, had a magnificent pair of tusks, sticking fully five feet out of his head, had now partially emerged from the jungle, so motioning to Ntawasie to stay where he was, I stole forward, feeling quite confident of bagging him with the first or second shot. Nearer and nearer I crept, and was about fifty yards from the elephant, when I heard a furious growling behind me, and, next moment, Whisky, who had evidently slipped his leash, bounded past me and clashed straight towards the tusker. I instantly raised my rifle, fully expecting that the elephant, warned by Whisky of our presence, would clear back into the long grass: but instead of doing so, he came quickly forward, as if wondering what new species of animal he had suddenly come across. As he was now only forty yards off and presenting a perfect view for a shot, I felt that I could place a bullet in 


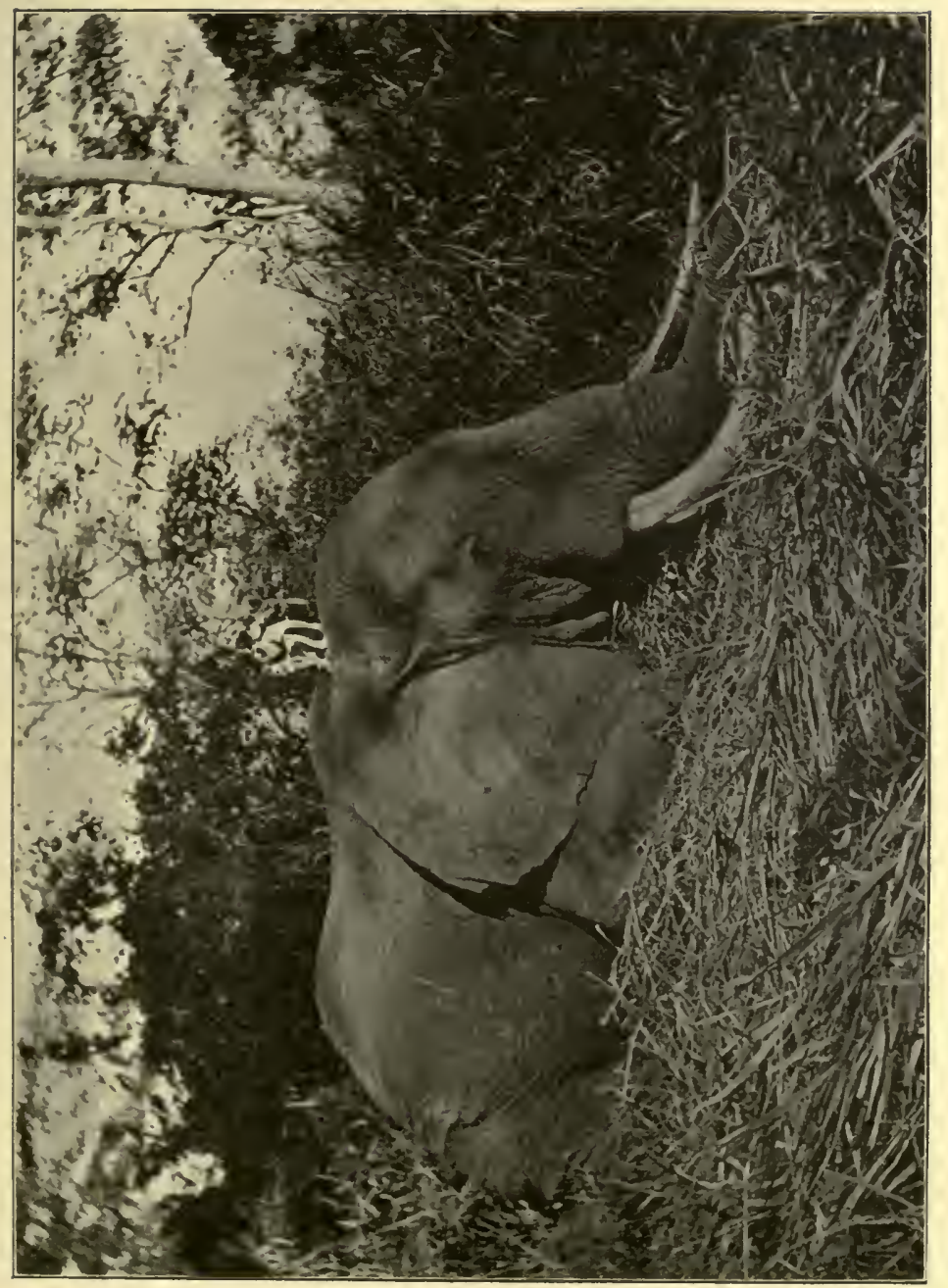

造 
any inch of his anatomy that I desired, especially as he seemed quite unconscious of my presence, and wholly occupied with my terrier. Whisky, quite undaunted and growling furiously, bounded up to the monster, and the little devil's whole attitude seemed to convey a warning to the mountainous bulk beside him that there was little doubt in his mind as to who would get the worst of an encounter. The huge beast, with an elephant's characteristic inquisitiveness, extended his trunk and began to sniff at my dog, who, no doubt, considering this an indignity not under any circumstances to be tolerated from a mere elephant, made a vicious snap at the latter's investigating proboscis. Whether the elephant had in the first instance intended to grab the game little dog I don't know, but considering this act of Whisky's an opening of hostilities, he simply seized his tiny antagonist and flung him some twenty yards into the jungle. Then, quietly turning round, as if expecting the audacious little dog to return, he moved slowly towards the long grass into which his opponent had incontinently vanished.

I felt that it was now high time for me to take a hand in the unequal contest, but so interested had I been in the strange incidents of the past few minutes that I had let slip the chance of getting a good shot, and had to be satisfied with aiming a short 
distance behind the brute's ear so as to get the line of his brain. He instantly dropped to his knees, but rose again almost at once. My second bullet struck him in the vicinity of the heart and sent him crashing back into the long grass, where he fell ere he had travelled another forty yards.

Whisky was none the worse for his unexpected trip through the air, and though, at first, he fought shy of approaching the elephant's carcase, he seemed at once to realize, when I placed him up on the beast's back, that his formidable opponent was dead. The photograph illustrating this episode, shows him standing proudly on his fallen foe, no doubt convinced that though his master had slain the monster, the result would have been vastly different, if he hadn't given that poor fellow a helping hand. 


\section{CHAPTER XIX}

THE TROPICS AND THE CALL

It seems to be the general opinion in Europe that those who spend the greater part of their lives in the tropics eventually come back to northern climes morally and physically bankrupt, and this conception is, no doubt, founded on a considerable basis of truth. Many who return from tropical countries have acquired a 'liver,' and the sallow skin and hollow eyes accompanying that complaint, to say nothing of the various frailties that fever leaves in its wake. Tropical Africa is, without a doubt, a hard task-master, and demands certain qualifications in those who wish to live and pioneer successfully in that continent. The physical weakling, and those who cannot get along without the good things of this life, had better stay away: they will only go to join the long list of victims that the trying climate of the equator claims, year in, year out. Nor is sound physical equipment the only 
requirement : a man must be so mentally balanced that he can withstand moral temptation in its worst form, and be blessed with that equable temperament which refuses to be worried by the petty disappointments and discomforts inseparable from a pioneer's life. Even then, he must pay ceaseless attention to his physical well-being in order to stand the climate. As for those who are prepared to do this, and feel that they have the other necessary qualifications, let them try the tropics and they will not be disappointed! The question of being able to make a living in the Old Country is no criterion of a man's colonizing capabilities. If he is a waster, stern Nature, I'm afraid, will soon eliminate him; if his is the temperament that loves action and feels restricted by the monotonous round of life in a great city, if he feels a pressing desire for the wild, and finds solitude a solace instead of a boredom, then he has some of the elements that fit him for 'roughing it' in the tropics. I think there is a peculiar charm in the freedom of these vast open spaces, the ever-changing scenes that delight the eye, and the little adventures that are inseparable from a wild life. Unfortunately, our old world seems to be getting filled at an enormous pace, and there are few places left where the traveller, seeking the delights of untamed nature, is many days distant from civilization in some form or other. 
I have often wondered what will happen when there is no wild to tempt the daring spirit. from the comparative safety and comfort of civilization to wander forth and seek adventure for the very exhilaration that it affords. Surely, love of excitement will always be a part of human nature!

It is a generally accepted fact that nearly all those who have lived a considerable portion of their lives in the tropics experience a decided desire to return. It is a yearning that is well-nigh irresistible, and, more often than not, obeyed-a call which is felt by the West Coaster as strongly as by his brother of the East Coast. I have heard many opinions expressed on the subject and have frequently tried to analyse the nature of this peculiar yearning.

In the first place, a man living away from civilization is naturally free from all the restraints of that civilization, and those confining influences which, in his youth, drove him from the compensating luxuries of an old country to seek the heart of the wild, are naturally more irksome to him on his return than ever. Away in the back of beyond, he is not obliged to observe the innumerable petty points of convention with which public opinion demands compliance in densely populated areas, and which to many minds reduce existence, in a phrase of Carlyle, to a 'highly complicated egg- 
dance,' to be danced without breaking a single egg. Another point on which I should like to insist is that, among natives, the white man is respected and obeyed, and even granting this to be a surface allegiance, it imparts a sense of superiority, which, however conscious a philosophic man may be of its ultimate futility, indubitably enlarges his own innate sense of self-respect. I do not think anyone who looks this fact coldly in the face can deny its power among all races and men, for it is certainly at the root of all sane human social systems, however much people may try to think otherwise. This salutary sense of superiority is, moreover, certainly assisted by the fact that in the wild a man has only his own sense of right and wrong to guide him, a circumstance which makes him morally his own master and ruler, and gives him complete confidence in his own judgment. On the other hand, when he returns home, he feels physically lost in the swarm of human beings that throng a great city, and experiences the disconcerting idea that he has, somehow or other, lost his personality and dwindled to insignificance in the vast sea of the commonplace. Also, in a white man's dealing with natives, his word is essentially his bond, and there is no going back on that word if you are to breed confidence and trust among your men. You may break that word if you wish, for there is no written 
and stamped agreement to bring you before a tribunal, but you will eventually lose more than you have temporarily gained. I think this reliance of one man upon another breeds sincerity, and insincerity is such a marked defect of all civilized life. Then, in civilization, there is the almost universal worship of wealth, the ceaseless striving for which cannot bring out the best in a man's mind or body. In the tropics, you may chance, if luck favours you, to make enough to keep you in comparative comfort for the rest of your days, but you have, in most instances, to make it by healthy work in the open, generally by the sweat of your brow, and under conditions which give you leisure to think.

Lastly, there is the beautiful country and the sun! There may be some people who yearn for grey skies; the majority, I think, prefer the joy and brightness of sunshine. Gorgeous flowers and butterflies, that surpass in their tints the most beautiful of enamels, song-birds that keep the forests cheery with their music, the perpetual laughter and chatter of natives, the mystery of the lonely, uninhabited pori, the glorious moonshine and the startling brilliance of the stars, the absolute freedom from the noise of cities-all go to create a romantic atmosphere which seems to tinge the mind and creep insidiously into the blood. The memory 
of these things (and what a glamour memory can cast over the realities of the past!), I think, constitutes that wistful yearning which is termed the call, and you have only to live the life for some years to experience the irresistible pull that it gives to the heart-strings. 


\section{CHAPTER XX}

SOME NOTES ON THE LIFE OF THE AFRICAN NATIVE

To the white man who has not spent any of his time in Africa, the life of the average African native is a sealed book; and as there are very great differences of opinion as to the value of that phrase; 'the happy savage,' especially in relation to the social conditions of the masses in civilized countries, a brief description of the usual way in which that 'savage' lives may be of interest and furnish material from which the reader can draw his own conclusions.

Though customs differ in different districts, there is a great similarity in the home life of natives of most African tribes, more especially those inhabiting that tract of Africa between the Zambesi River and Khartum. The negro comes into the world without either much pain or much forethought on the part of his mother, and goes through life happy and careless. Till the age of eight or nine, he plays about his village as blithe and merry as a puppy or 
kitten: no school-board officer troubles his sunny days; he has no perpetual nightmare of scamped lessons to disturb his childish slumber. His sole occupation, save when he is sent on an errand by his parents, consists of his games, into which he enters with all the gusto of an absolutely untrammelled

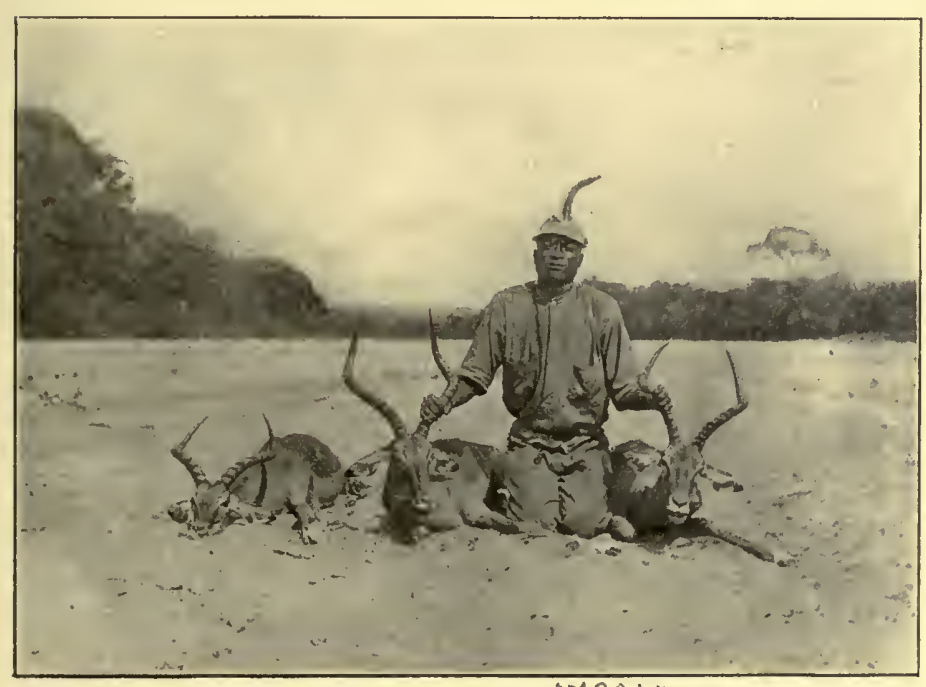

MY TRACKER SIMBA WITH THREE INSWALA JUST SHOT.

nature. He has also his little toy puzzles like civilized children, and the game which has been given the name of diabolo in England has been known to African children time out of mind. His education is short and terminates with his ability to count ten, though his imagination and mental powers are certainly enlarged by the tales and legends he hears from his elders as they sit around the fire at night. 
The close of his childhood may roughly be fixed at the age of ten, when he enters more fully into the life of the village and accompanies his elders on hunting and fishing expeditions, either participating in the sport or assisting as a carrier. Coming to maturity early, as all Africans do, he usually marries between the ages of ten and twelve, and is then admitted into full companionship with his elders. He now sets up house, so to speak, he and his wife building their future home together, There is no necessity to buy furniture on the instalment system, for theirs is actually the simple life. A bed, some mats, calabashes for water, utensils for grinding corn and crushing and cooking food, form all their household goods-in fact, you could put the furniture of a whole village into a pantechnicon. From the date of his marriage commences the most arduous portion of his life. He has now to make himself a shamba (garden), so that he may grow the simple necessaries that form his daily bread. There is no question of landlord and tenant to worry him; he simply marks out the earth that no man owns and clears it for cultivation, and the natural freedom of this act has always presented to my mind a vivid contrast to the trespass laws, the barbed wire and the lordly sense of proprietorship that attach to land in the Old Country.

After a while, our native may fall in love with 
other lips and other eyes, and finally decide to take a second wife. The first wife may feel the pangs of jealousy and the humiliation of being superseded in her husband's affections by another, but these trifles she will have to look at philosophically, or to put it expressively, if vulgarly, she will have to 'lump it.' For his second wife, our amorous native must build a new hut, and to her he must give a bed of her own, while she provides a mat. Now, he chiefly confines his attentions to hunting and fishing, and making expeditions into the forest for honey, bees-wax and rubber, leaving his wives to do most of the manual labour in the shamba.

Bye and bye, if he is well-to-do, he may decide to add another wife to his household, and from this event, we may roughly date the beginning of his declining years. His physical powers begin to wane, and he passes his time in the village gossiping, very much as the aged English villager does in the village inn. By this time he has a family of one, two, or three children, large families being an exception, and these children, especially the girls, assist their mother in the housework. Sometimes, he will make little trips to adjacent villages and exchange a fowl for some tobacco or for seed for his garden. With such trifles he whiles away the time.

At thirty-five to forty he is an old man, and then 
his principal care is to see that his wives do not make love to other women's husbands-perhaps the most difficult of all the tasks he has ever undertaken, and one in which, I can assure the reader, he generally fails.

Among the natives of East Central Africa, the status of a woman varies according to whether she is a wife or merely a slave. Though the husband is lord and master, let not the reader infer that he treats his wife inhumanly, or that the little amenities which characterize the union of civilized men and women are lacking from the married lives of natives. At worst, a negro is more or less a mentally undeveloped man : elemental feelings such as love of wife, children and parents, of fraternity and of friendship are his as well as ours, and, as we know, the varnish of civilization does not always tend to strengthen these basic factors of human character. Among them, just as among ourselves, a woman, if she has a grievance, may have recourse to the law-rude as that law in many instances is. If a man maltreats his wife, she can always complain to her relatives, who either settle the matter with the husband or bring it for justice before the headman of the village. If the quarrel is merely in the nature of a tiff, the wife may run away to her mother, but there is no budding humorist to discover the funny side of such an act and keep the 
joke green in so-called comic weekly papers. On such occasions, the mother, bringing a wide experience to bear on the subject, will probably tell her daughter not to be silly, and, ere long, the young couple have made friends and discovered that a lover's quarrel merely means the renewal of love. Should the difference be of a serious nature the husband will probably divorce his wife, but after such an event, she does not live as a woman with a lurid past. There is always another husband waiting for her, and the fact of her being a divorcee does not cast the slightest "reflection on her eligibility for remarriage.

The native woman's appearance, apart from the facial aspect which may be displeasing to the eye of the white man, is certainly prepossessing, for the exercise of her household duties, of grinding food, of carrying water and working in the shamba, develops her to physical perfection. She is, moreover, if she has adopted the Mahometan faith-and most of the natives of Eastern and Central Africa are rapidly becoming followers of the Prophetscrupulously clean as to her person, washing her body once or twice a day and always before retiring. Like her white sister, she takes great care of her appearance : her hair and skin she keeps soft and in perfect condition with the application of a little oil, usually the ufuta, which is odourless and so readily 
absorbed by skin and hair that it is neither sticky nor greasy. Her hair she washes once a month, using the leaves of a saponaceous plant instead of soap, which latter-day product the natives say dries up the hair and makes it turn grey. She cleans her teeth with a utensil which she fashions by chewing a twig of a saponaceous shrub until it is fibrous, and this natural but effective tooth-brush requires no dentifrice. In addition to the above care of her person, her food is wholesome and deliciously cooked, consisting of fish, vegetables, flour-foods, fruit, and occasional fowls, and there are no afternoon teas to disturb her digestion and affect her nerves. She does not indulge in late and mysteriously cooked suppers, but retires to rest about two hours after sun-down and is up again at sunrise. Her clothing has the looseness that permits of perfect freedom of action, and in this respect she closely, if unconsciously, follows the Grecian ideal. A woman's dress usually consists of two pieces of cloth (called kangas), which she winds gracefully about her person. All native women love jewellery, such as rings, bracelets, and necklaces; and silver ornaments form an excellent contrast to their dark skins. Both sexes are passionately fond of dancing.

The physical endurance of the African native is great, and my carriers constantly carry loads 
varying from 60 to 80 pounds from early morning till evening under the rays of a tropical sun, often going without food, or water, or both, when circumstances demand. Moreover, the journey is performed through the most exacting country, up hill and down dale, doubling under branches and bent trees, and winding through thick, thorny elephant grass. If we have the luck to come across water, all the better, if not, we sleep without food or water until it is reached the next day. Even then, the rest is often of the briefest duration; food is hurriedly cooked and eaten, and we are off again.

Combined with the native's bodily vigour, is usually the cheerful contentment that good health promotes, and his open-air life and habits give him a certain amount of physical courage. I have chosen my trackers particularly on account of their fearlessness and presence of mind in the face of danger, and they and my carriers are as keenly interested in hunting as I am myself. Several times, when I have been following up elephants and there has been a probability of our not coming up with them, a circumstance which may entail our sleeping on the spoor, passing a thirsty night, and starting after them again at dawn, I have waited for the arrival of my carriers, and told them that, as we might not find water again that day, they were at liberty to retrace their steps to the last water-hole 
and await my return. They have invariably replied in the negative, saying that if my trackers and I can endure the hardship, they also can and will, and pointing out that if they were to return to camp and I kill an elephant in their absence, they would only be cbjects of derision to their womenfolk.

Though the native-I do not refer to the coast native-is instinctively fond of hunting, he lives on what he grows in his shamba or garden, and in comparison with the labourer in civilized countries gets the necessaries of life easily. When about to clear the virgin forest for his garden, he asks his wife to make a lot of beer, and then invites all his friends to come and help him with the undertaking. They arrive and set to work with a will, and ere long they have the trees cut and stacked aside. When the work is finished, the host treats them to unlimited beer, and if a wife makes good beer, she is known for miles around. The shamba is now ready for cultivation, and with very little labour yields him anything between one to four crops of Indian corn a year. In addition, he grows matama (their chief grain food), sweet potatoes, rice, mealies, bananas, several kinds of beans and peas, melons, and pumpkins and vegetable marrows in variety. $\mathrm{He}$ seldom suffers from lack of food, and experiences, therefore, no difficulty about feeding his children, while day in, day out, all the year round, he himself 
can drink beer, either the liquor brewed by his friends, or that made from the products of his own garden. I think this forms a striking contrast to the absolute penury and struggle for a bare existence, among wretched surroundings, that is the lot of the greater part of the working classes in civilized countries to-day. With reference to the cheapness of food, it may. interest the housewife to know that six to eight fowls may be bought for one shilling and fourpence, and fifty to a hundred eggs for the same money.

Considering the native as to his mental aspect, I should describe him as intensely natural, and when his mind comes into contact with European ideas of justice, the consequence is sometimes ludicrous in the extreme. Let me give an example in illustration.

A year or so ago, a native came to the Boma at Liwale to complain that a confederate had swindled him out of the proceeds of a robbery, and begged the Bwana Mkubwa (Big Master) to see that justice was done. Asked to state his case, he said that, during the native rebellion in 1906, he and another man had murdered an Indian trader and looted his stock of goods and money, and that, up to date, his accomplice in the crime had not divided the spoil in an equitable manner. The magistrate managed to keep an unmoved countenance and sent 
the plaintiff with a couple of askaris to arrest the confederate. This was done, and he was brought and charged before the magistrate. Ludicrous as it may seem, his defence was that, as he had murdered the Indian himself, with very little assistance from the plaintiff, he was naturally entitled to the lion's share of the spoil. Subsequently, they were both tried, found guilty of murder, and executed, and even to the very last they were firmly convinced that someone in authority had blundered, and that, somehow or other, there had been a dreadful miscarriage of justice.

On another occasion, one of my servants came to me in great distress, saying that his wife's murderer had just arrived in the district, and asking me to have him arrested. Explaining the matter, he said that the murder had been committed ten years ago, and on my asking him how he recognized the delinquent after the lapse of so many years, he replied that he could not be sure of his identity, but felt certain that the man must be the actual murderer, for he had been boasting of the deed. I sent for the man in question and he came quite willingly. He made no secret of the fact that ten years previously he had killed a woman, but said he was rather hazy as to whether it was my man's wife or not.

I sent him to the nearest magistrate, but the 
latter refused to take any action owing to the length of time that had elapsed since the perpetration of the crime.

With regard to religion, most of the coast natives and a great number of those of the interior have embraced Moslemism. The remainder are practically without religion at all, and are called shenzis (heathens) by their Mahometan brothers. They have some conception of a Supreme Being, but very little idea of a hereafter, save perhaps the belief in a reincarnation in the form of some animal or other. Simba, my tracker, a man of great force of character and absolutely without fear, once expressed his views on this subject of reincarnation to me.

'Master,' he said, 'when I die, I should like my spirit to go into a wild dog, because the wild dog can kill almost any of the beasts of the forest. $\mathrm{He}$ is swift and tireless, and can get food with ease and is the only animal against which the black man's hand is never turned.'

I once had a tracker called Matomoro, who was, by the way, a very gay Lothario, and, on one occasion, preparatory to going on a hunt, I heard Matomoro's father, well primed with pombe, giving his son the following brief lecture on the conduct of life. It may be a simple one, but aptly fits the native mind. 
'When it's war-well, that's our work! When it's hunting, well, that's our work! When it's lovemaking, there's no denying that that's our work too! But, my son, whichever it is, do it thoroughly and "Fanisa kassee kinaoomi" (play a manly game).' 


\section{CHAPTER XXI}

THE WILD MAN OF THE GOLAMBEPO MOUNTAINS

Some years ago, I was hunting in the Golambepo Mountains that fringe the eastern shores of Lake Nyassa, and my camp was pitched near the Letombochie stream. The country that sweeps from the Golambepo to the Awembe Mountains, with lofty ridge and deep ravine, is perhaps the most romantic that it has been my lot to see. Early in the morning, snowy mists cap the peaks, and from their chilly heights, clear, cold rivulets leap and dash, shining in the sunlight, to the warm valleys far below. High up, where the vegetation is stunted, the aspect is bleak and heartless, and, gradually, the flora, as if gaining strength in the descent, like some mountain stream, becomes more and more beautiful and finally bursts into wild tropical luxuriance in the heat of the lowlands. In the uplands, the air is so cool that, on occasions, for want of other fuel, we have been obliged to gather dry elephant dung for a fire, in order to enjoy 
the welcome luxury of a blaze. Though elephants do not frequent these altitudes, they sometimes traverse them in order to reach special districts where they know that their favourite foods are in abundance, and here, as in all regions where elephants roam, for miles and miles you may follow a beaten elephant track, one to three feet wide, clean and hard as a pavement, which these huge beasts have trodden from time immemorial. These paths are their highways, and, here and there, they diverge, or are intersected by cross roads, like roads made by man, and their presence brings vividly before the mind the almost human intelligence of the creatures that make them. Often, I have followed elephants through bush, and wondered why they were trekking a country devoid of the trees on which they feed, only to discover that they were making directly for one of these elephant paths.

To return to my story: I was one afternoon enjoying a siesta in my tent when my curiosity was suddenly aroused by a great commotion among my men, and on going to inquire the cause of the hubbub, found them gathered together in a group round some central object of interest. As I approached, they made way for me, and my gaze fell upon the cause of all the excitement. It was something in the form of a man; once undoubtedly 
it had been a man, but now all human intelligence seemed to have departed from the eyes, and left behind only the quick, furtive glance of the wild animal. His hair and beard were long, grey, and unkempt; his face haggard, weather-beaten and deeply lined; his form gaunt and wizened with age and privation. Clothes he had completely dispensed with, and there was in his attitude and demeanour that timorous shrinking from contact with man so characteristic of wild nature. Altogether, he was an object of pity, the deeper on account of its hopelessness-this creature that had once been like others of his kind!

I questioned my men as to how they had come by him and Usufu, my boy, said that they had been into the forest in quest of honey and had found him sleeping; that he was well known to them as the wild man of the Golambepo, and had often before been caught by others of my men. After some questioning, I managed to elicit from them the whole story of the poor fellow's career.

Long, long ago, before ever the white man had been heard of, this old fellow had been the head of a big village on the Msinjie River. His people were living contentedly and happy; there were lots of children and plenty of food, when, without any warning, came disaster, as disasters often occur in this world. One night, when all the village were 
peacefully sleeping, a party of Arab slavers and their miscreant followers, the ruka-ruka, swooped down. upon the huts, butchered the old men and women in cold blood, and captured the young men, women and children for slaves. Wakened by the noise of the burning thatch and the agonized cries of the wounded and dying outside, the headman had risen from his kitanda (bed) and rushed out of the blazing hut. His wife, carrying their only child, had just dashed out before him, and ere he could overtake them, he saw in the light from the conflagration a ruka-ruka run up and despatch the woman and babe with a scimitar before his very eyes. Springing upon the fiend, he killed him with a blow from his knife, and fled into the comparative safety of the forest.

From that evil day, he had never returned to the haunts of men, but had ever since dwelt in the pori, living on locusts and fruit and wild honey, supplemented with the birds and small game that he had managed to trap. Constant brooding on the awful disaster that had befallen him and his people had at length driven him mad. Often, the people of the neighbouring villages had caught and brought him into their kraals and treated him kindly, but he had never stayed long with them, usually seizing the first opportunity to escape.

I made my men cut the ropes with which they 
had bound him, and asked them to give him food, a hut to sleep in, and to be kind to him, hoping that tactful treatment might induce him to remain comfortably among his fellows. I gave him clothes, but after wearing them a few hours he discarded them altogether and never wore them again. During the week or so that he stayed with me, he remained most of the time in the seclusion of his hut, as if averse to mix with human beings, and after going and seeing him a few times, I came to the conclusion that his mind was beyond all hope of return to the normal. Then, one morning, when my boy wakened me, he told me that the wild man had gone back to the pori. During the night, when all were asleep, he had quietly slipped out of our camp and returned to his retreat in the lonely Golambepo Mountains. I never saw him again, but every time I chance upon slaves in my travels, it recalls to me the sad story of that poor maniac wandering homeless through the trackless forests, once a human being, now scarcely more than a wild beast, a tragic example of 'man's inhumanity to man.' 


\section{CHAPTER XXII}

\section{HIPPO AND LION}

THE hippopotamus, imbued, like all wild animals, with an instinctive fear of man, only ventures at night in search of food from the security of the river or pool that he frequents, and when bent on this search will, at times, wander quite a distance from the actual water.

Prior to the incident which I am going to relate, my natives had often told me that they had found dead hippos at a considerable distance from water, and that, from marks upon the carcases, they were absolutely certain that lions had killed the animals and fed upon the flesh. I had always discredited, or, perhaps, to put it more aptly, taken their stories with a pinch of salt, until on one occasion, near the Msinjie River, I met with an experience which fully corroborated their statements. As we were tramping along parallel with the river, about seventy yards from the banks, I heard the repeated snorts of a hippo, and, at once going 
in the direction of the sound, came upon an extraordinary sight. A lion, having sprung upon a hippopotamus, was tearing fiercely at the poor animal's head with his cruel claws and biting him viciously in the region of the ear, while the hippo, dazed with the onslaught and blinded with the pain, was crashing aimlessly through the grass, going round and round in circles, in a futile effort to rid himself of his antagonist. In the struggle, they got clear of the long grass, and came into the open, where I had a splendid view of the one-sided contest; but so keen is the scent of a lion that, intent as he was on trying to kill his victim, he caught a whiff of our scent and, looking round and seeing us, dropped from the hippo's shoulders and made swiftly for the long jungle grass. Taking hasty aim, I fired, the bullet striking him in the hip just as he disappeared, while the hippo, freed from his persecutor, rushed madly down to the river and plunged into a deep pool. Following the animal's tracks, I came down to the water and, about a quarter of an hour afterwards, when he rose to the surface to blow, I fired and felt sure that the bullet had penetrated his brain by the peculiar upward jerk that he gave his head and the way he instantly sank. Leaving some of my men to wait for his body to float (which 
usually occurs about two hours after death), I set off in pursuit of the lion. We followed his tracks for some hours, but as he had only received a flesh wound and the blood spoor was very slight, we eventually lost all trace of him.

Towards evening, I returned to the river, where I found that my men had already succeeded in dragging the hippo's lumbering body ashore. On examining the carcase, I discovered that the lion, besides covering the animal's face and head with claw marks, had gouged out his left eye and almost bitten off his right ear, the nature of the wounds leaving little doubt in my mind that he would have managed to kill his victim, had I not appeared so inopportunely on the scene. 


\section{CHAPTER XXIII \\ SUPERSTITION AND A SEQUEL}

Everything connected with elephant hunting and the buying and selling of ivory is inseparably interwoven in the native mind with an extraordinary medley of superstition; and the snake, which has, through all the ages, awakened in the human imagination a sense of mystery mingled with horror, plays a prominent part in these strange beliefs. For instance, should a hunter, while hunting, suddenly encounter a snake, more especially a puff-adder, he considers the meeting a good augury. On the other hand, should he meet a chameleon, it. is an extremely inauspicious omen, and to kill the reptile only makes matters worse.

While on the spoor of elephants, I frequently encounter snakes and my trackers, on such occasions, never fail to presage that the result of the hunt will be favourable, and, though I usually laugh at their predictions, I must admit that in most instances they turn out true. Whenever this is the 
case, my natives always jokingly remind me of the fact by saying, 'Bwana, you don't believe in our superstitions, yet you see there is something in them after all.'

Once, near the Myaeah Mountains and in the vicinity of the Lumasuli River, I came across the tracks of three elephants and after an arduous chase shot one of the herd, the other two effecting their escape. As we were dog-tired, I called a halt and pitched camp, and soon a cheery kettle was singing, over glowing embers, a pæan in praise of that most refreshing of beverages-tea. After a brief rest and before settling down for the evening, I set out with my trackers to reconnoitre the surrounding country, never dreaming that we should encounter elephants on the way. As we trudged easily along, we suddenly came across a beautiful pool of water, fringed with rustling bamboos and starred with waterlilies; and entwined among the reeds overhanging the margin of the mere, lurked the deadly coils of a snake known to the natives as the jokomahamba (or green namba), one of the largest and most venomous snakes in Africa. The reptile was evidently lying in wait for any small game that might come to drink at the pool, so raising my 10'75 rifle, I took aim and fired, the bullet cutting its body in two. Both sections fell to the ground, the forepart containing the 
head at once coming straight towards me, and a similar incident, incredible as it may seem, has occurred to me more than once in my hunting career. Shooting again, I cut the advancing forepart in halves, this time about eighteen inches from the head, and still the reptile strove to wriggle towards us, until one of my men, running up, finished matters by smashing its head to a pulp with a stick. It has always seemed an amazing fact to me that the shattering action of a bullet does not, in severing a snake in two, utterly paralyse the section containing the head.

However, to resume my story, only a few minutes after this rencontre with the jokomahamba, we came across the fresh manure of the two elephants that we had persuaded ourselves were miles away, and starting off at once in pursuit, managed without undue difficulty to bag both of them, Simba stoutly averring that we had been lucky on our hunt simply because we had met with the snake.

Sometimes, a dying elephant will take hold of a tree with his trunk to prevent himself falling, and when this occurs the inference drawn by the natives who are hunting is that the wife of the man who fired the first shot is undoubtedly proving faithless to him. If an elephant or buffalo charges a native after he has fired and wounded it, the same deduction is drawn, but should he be charged by the 
quarry before firing, the hunter in question at once returns to his home, saying the safari is logoed (bewitched), probably because his wife is proving herself a disciple of Messalina Valeria. On reaching his village, he puts his suspected wife or female slave through the poison ordeal, which is so arranged that some one is ultimately made the scapegoat, and as wives and slaves are generally considered much too precious to lose, the poison is, in most cases, administered to an unoffending fowl. If the fowl dies, the accused is at once punished; if it lives, the accused, to put it in hackneyed phrase, 'leaves the court without a stain on her character.' Now, some one is certainly guilty of misbehaviour and she must be found, so another wife is accused and the fowl house is called upon to supply another martyr to justice. Probably, though it can never be asserted as an incontrovertible fact, the native hunter has predetermined which wife is to receive punishment, and when her turn for trial comes round, gives a more potent dose of poison to the fowl that is to serve as an index to her probity or guilt.

Some years ago, at the Lumasuli River, I engaged an elephant hunter of the name of Makabuli to take me to the haunts of elephants in this district, and one evening, having encamped near a water-hole, we heard, near by, the smashing 
of trees by an elephant. Rushing out in pursuit, we found that the animal was only a young male with insignificant tusks, who, as an elephant often will, came inquisitively on to see what new species of animal he had suddenly encountered. Makabuli at once sprang away to the rear, and the young elephant made a short, easy rush after him, as if wishing to give him a good fright. At the same instant I fired in the air, hoping to scare the animal away, and, as I had expected, the noise of the discharge sent him off full speed in the opposite direction.

That night Makabuli, obsessed with the idea that one of his wives was proving faithless to him, was in such a state of excitement that he could not sleep, and no amount of assurance on my part that his troubles were merely imaginary would pacify him. He expressed a wish to return to camp at once, but I was obliged to refuse him this favour, because he was the only one of our party who was well acquainted with the country.

Early next forenoon, having come across the fresh spoor of four large tuskers and decided to follow them up, I all at once discovered that Makabuli, who was carrying extra cartridges for my heavy rifle, my binoculars, and rifle telescope, was missing, and thinking that a lion must have seized him, or that some other mishap had befallen him, I 
immediately sent my men to scour the long grass in search of him. But all they discovered was Makabuli's tracks leading straight back to camp, and, as I could not spare men to send in pursuit of him at

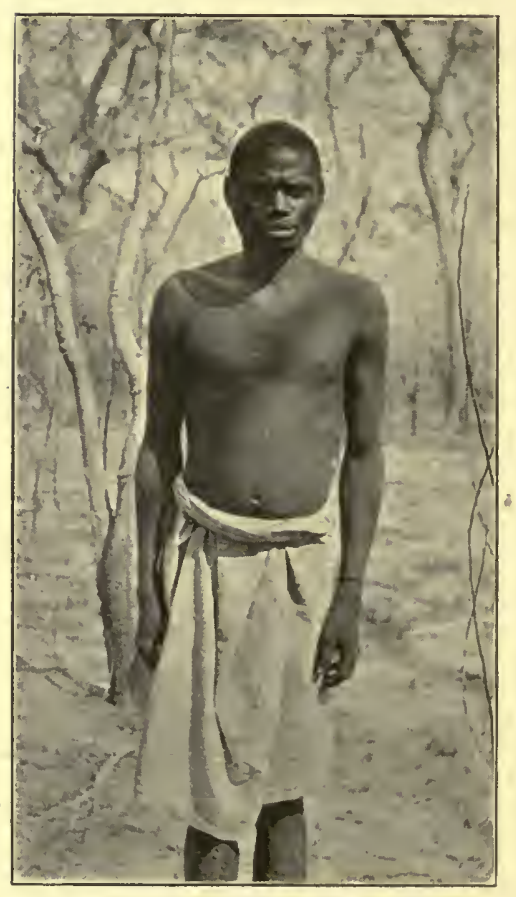

MAKABULI such an awkward time, we continued the hunt and managed to bag a couple of the herd.

$\mathrm{Next}$ day, we turned our steps homeward, and, on arriving at our destination, learned that Makabuli had reached camp on the previous evening. Still brooding over the little incident of the charging elephant, he had gone in search of his wives, and had found one of them actually drinking pombe (beer) and flirting with one of my men. Burning with jealousy, Makabuli was more convinced than ever that his suspicions were not utterly groundless, so, taking his wife to his hut, he belaboured her soundly, burning her hands and tearing all her 
clothes by way of chastisement for her unseemly conduct.

Those of my men who had been left in camp then asked him how it was that he had returned with my cartridges, binoculars, etc., to which he replied that I had given him permission, but they, with the keen intuition of their race, guessed that he had deserted, and promptly tied him up pending my return. My men's wives, infuriated at the brutal way Makabuli had treated his wife, begged me on my return to punish him severely. Feeling that Makabuli deserved it, I told them that they had better take the law into their own hands and mete out the punishment they thought most appropriate to the occasion. This they promptly did: about a dozen of them (and I may say that a native woman is no weakling) soundly thrashed him, and, as a native can suffer no greater humiliation than to be beaten by women, Makabuli, I think, thoroughly expiated his misdemeanour. 


\section{CHAPTER XXIV}

\section{NERVES AT NTUNKWAE}

In June, I908, whilst on the way from Lindi to the Mahenge district, I was obliged to lie up at a small village near Ntunkwae Hill, about three days' journey from the Songea Collectorate; for I had been suffering for about a month from recurrent attacks of tick-fever, which had reduced me to a thoroughly exhausted condition.

One morning, during my enforced stay in the locality, I was roused from sleep and informed by the village headman, Potosambo, that two of his men, who had been into the forest in search of bees-wax, had just returned with the report that a large elephant, which had killed a native hunter the previous evening, was only a few miles off in the neighbourhood. Hearing that a European was encamped in the village, they had travelled all night to inform him of this disaster, in the hope of inducing him to come and slay the elephant, which, they averred, was well 
known to them, and had exceptionally small feet in comparison with the enormous size of his tusks.

The idea of an elephant hunt did not appeal to me in my low state of health as the most desirable thing on earth, but, persuaded by their persistent entreaties, I at length decided to set out in a maschilla for the native hunters' camp, for I was much too weak to do any prolonged marching. Arriving at my destination about ten o'clock, I saw the remains of their companion who had been killed the previous evening, and, as long as I live, I shall never forget the sight! His body was shockingly trampled, his head crushed to a pulp, as if it had been pounded under a steam hammer, and in his stomach there was a frightful gash inflicted by the animal's tusk. To a man whose energy had been sapped by a month's fever, the spectacle was not an encouraging preliminary to setting out on an elephant hunt, so, striving to forget the ghastly details of the affair, I took leave of the native hunters and, accompanied by my trackers and men, began my search for the murderer's spoor. Ere long, we came upon his tracks, which crossed and recrossed in the bamboos and long jungle grass abounding in this part of the country, and after a few hours' steady progress, knew, by the clear impressions of his feet, that we were drawing closer to our quarry. I now got out of my maschilla, and 
cautioning my men to keep a considerable distance behind, lest they should disturb the elephant, proceeded to follow up the spoor on foot, my tracker, Malingum, carrying my heavy double rifle, and Ntawasie my light $10.75 \mathrm{~mm}$. After another hour's work, we came up with the animal standing stock-still in a thicket of bamboos about fifty yards distant, with his head turned away from us ; and, as the wind was blowing at a dangerous angle from us to him and the level, bamboo and grass-covered country rendered a detour difficult, I decided to wait a few minutes, hoping that he might turn slightly and give me the opportunity of placing a bullet in a vital spot. At this juncture, a faint trace of our scent must have reached him, for he began tentatively sniffing the wind with his trunk, and turned his head slightly to the left. The moment was an anxious one, and Malingum, growing impatient, whispered: ' $\mathrm{He}$ has winded us, bwana; fire, or he will be off!' So, aiming several inches behind the animal's ear, at an angle that I calculated would ensure the bullet reaching his brain, I fired my first barrel, but was very much surprised to find that the brute did not even budge from where he stood. (I discovered on subsequent examination that the bullet had struck him too high up to be effective.) I promptly emptied my second barrel inito him aiming for his heart, and the instant 
the shot struck him he slewed round and charged us like lightning. Having no time to reload, I dropped my heavy rifle and, snatching my 10*75 from Ntawasie, who, with Malingum, now rushed to the rear for dear life, I sent my first shot full in the elephant's face, but the bullet had absolutely no

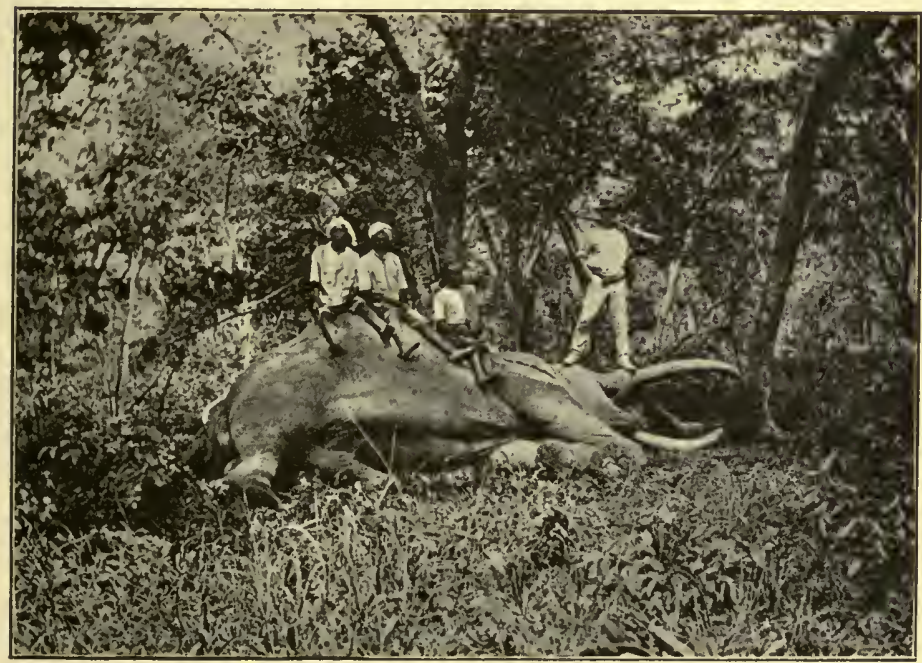

ELEPHANT WHICH NEARLY KILLED ME.

stopping effect, and on he came, the very embodiment of malign fury! When he was almost on me, I drove a second bullet into his skull and brought him down, only three yards from where I stood, and ere he could rise, I finished him with a third.

My post-mortem on the animal revealed to me that the heart shot that I had attempted with my 577 had struck him too high and too far back, while 
the first shot from my $10.75 \mathrm{~mm}$. had passed through the upper portion of his forehead, and I can only ascribe my poor shooting on this occasion to my weak condition and the unsteady state of my nerves, due to the repeated heavy doses of quinine that I had taken as a febrifuge. I can, moreover, assure the reader that it is no easy matter, after a solid month's fever, to manipulate in bush country a rifle weighing thirteen pounds.

The elephant which I had bagged proved to be a comparatively small animal, measuring just about eleven feet at the shoulder. His feet, as the natives had remarked, were peculiarly small for such an old beast; but, what was more important, his tusks were beautifully long and straight and weighed I 3 and Io7 lbs., respectively. On his carcase we counted the scars of twenty-seven old bullet wounds, and three fresh bullet wounds received from the native hunters whose companion he had killed on the previous day. One of the last-mentioned bullets had become imbedded in the vertebræ of his tail, and must have caused him considerable pain and rendered him unusually vicious.

This veteran of a hundred fights had, so the native hunters informed me, killed three other hunters in this district within the previous few years; one of them, Fundi Bakali, by driving a tusk through his chest and afterwards kneeling on his body; a 
second, Chokoma, of the Chacunda tribe, by a blow from his trunk and trampling on him; the third, Hongo, an Angoni, in a similar manner to Fundi Bakali.

The above little casualty list, I think, goes to prove that elephant hunting is not the tame sport that some writers would like to make out. 


\section{CHAPTER XXV}

\section{NAD BUFFALO ANI) FAITILESS WIFE}

I Do not wish to express any opinion as to the value of native superstitious beliefs, but their connection with an experience I once had with a buffalo brought about an extraordinary sequel. I will relate the story and leave the reader to formulate his own ideas upon the subject.

At the time in question, I was encamped at the Sultan Leanduka's village near the Luwegu River, a tributary of the Rufiji. One morning, about 2 o'clock, I was awakened by Malingum, one of my trackers, who came to tell me that some natives had just arrived, in a state of great excitement, with the report that an elephant was in the act of plundering one of their shambas, or gardens, and that in half an hour they could conduct me to the scene of spoliation. Feeling tired and sleepy and a little annoyed at this ruthless interruption of my peaceful slumbers at such an unearthly hour, I bade Malingum convey my sincere sympathy to the 
natives in question and tell them that they must wait till dawn, when I should come and try conclusions with the marauder. In a few choice but comprehensive phrases, I summarized my feelings on elephants and natives generally, and,

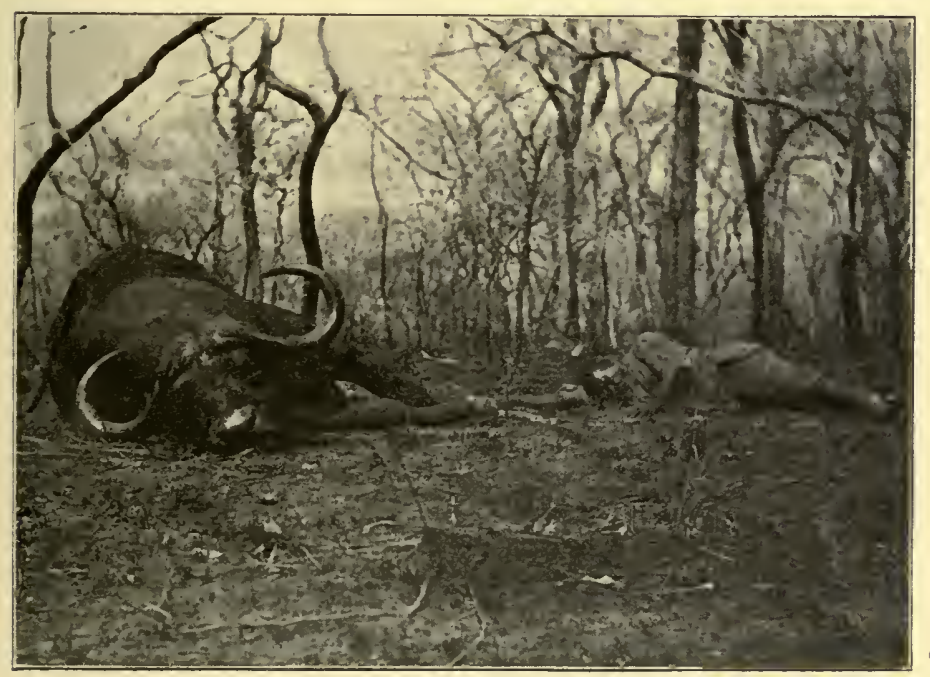

BUFFalo AND THE WOUNDED MalixguM.

somewhat relieved, pulled my blankets about me, and slipped once more into dreamland.

Half an hour after day-break found us in the shambas, where the elephant had wrought considerable havoc, and, picking up his spoor, we plunged into a dense thicket of long grass, which towered twelve to fifteen feet in height. My tracker, Malingum, carrying my 10\%7 rifle, was in front of me, intent on the spoor, my other tracker followed 
in my wake with my heavy double 577 , while a few native carriers, with some light baggage, were bringing up the rear, at a distance of several hundred yards. Confident that the elephant, who had gained a good start, was a long way ahead of us, we were hurrying along the spoor with somewhat less than our usual caution, when, all of a sudden, we heard, in the grass to our right, a loud crashing, accompanied by a series of short, angry grunts, which only too clearly indicated a charging buffalo. So taken by surprise were my men, that Malingum dashed away forward as hard as his legs could carry him and Hyiah promptly beat a hasty retreat, each carrying a rifle and leaving me to face the awkward situation unarmed. The buffalo emerged from the long grass only a few feet in front of me and, catching sight of Malingum making his record sprint, charged madly after him. The animal was fast overtaking my speedy tracker, when, to my horror, the latter caught his foot on some exposed root or other obstacle and went sprawling headlong to earth. Either being dazed by his fall or retaining his presence of mind, my tracker lay perfectly still, holding my rifle at arm's length above his head, slightly to the right of him. On thundered the buffalo, and, catching with his horns the rifle that Malingum held aloft, he tossed the weapon some twenty yards away, 
fortunately, as we afterwards discovered, without injuring it, though the stock still bears the marks of the rude encounter. Before my tracker had time to rise, the animal had turned, and was about to gore him, when Malingum, with frantic determination and admirable coolness, plunged his knife into the beast's right eye. This temporarily disconcerted the animal and gave my tracker time to roll aside, but, feeling that his victim was about to escape, the brute returned to the fray and, making a savage lunge at my man, fortunately missed hin, and smashed his right horn on the ground. Next moment, Malingum had nimbly regained his feet and was flying headlong in my direction, pursued by the enraged buffalo. At this critical juncture, Hyiah, having recovered from his fright, reappeared and handed me my heavy rifle, but as Malingum, disregarding my shouted orders to jump aside, only came on all the quicker, straight as a die to where we stood, it was quite impossible for me to get a shot at his pursuer. Next moment, the beast overtook the poor fellow, and with a sharp blow of his gigantic horns tossed him several yards away to the right. As he turned to finish his victim, I seized the opportunity for which I had been waiting and brought the brute down with a bullet through the shoulder, and ere he could rise, my second barrel 
gave him the coup de grâce. Rushing up to my tracker, who I felt sure had been killed, I was delighted to find not only that he was alive but that his injuries were far less serious than the nature of the encounter would have led one to expect. The blow that he had received from the buffalo's horn had badly bruised his thigh and cut a deep gash in the flesh, but luckily no bones were broken. The flesh wound I speedily disinfected and stitched up, a fine slip of sharpened bamboo serving as needle, the thread being procured by unravelling the twill of my khaki shirt-such is the rough and ready surgery of the pori-and ere a month had passed, Malingum had quite recovered from the ill-effects of his unexpected encounter.

The natives of the neighbouring village afterwards informed me that this very buffalo, which they said was undoubtedly mad, had killed two of their comrades who had followed it up.

The sequel attaching to this little adventure is as follows. When Malingum had quite recovered from his injuries, I noticed that he suffered from severe mental depression, and as he was one of those happy, laughing, devil-may-care, God-sendholidays-and-Sundays-often kind of fellows, who appeared to have a sweetheart in every village through which we passed, I was naturally at a loss to account for his strange change of manner. On 
my inquiring of him the cause of his unusual low spirits, he replied :-

'Oh, bwana, do you wonder at my feeling depressed? My wife must have taken another husband, for that is why the buffalo tried to kill me.'

All my endeavours to laugh the fellow out of this curious belief proved futile, and he, for whom life had always been an affair of bubbles and butterflies, went about his work a changed being.

Curiously enough, two months after this little conversation, some of Malingum's friends, hailing from the Fipa country, near Lake Tanganyika, about three hundred miles away, turned up at my camp, bringing with them a note for my tracker from his brother. On learning from this missive that his wife had deserted him for another man, my tracker at once brought the note for my perusal.

'Read this letter, bwana!' he cried. 'Didn't I tell you that my wife must have been faithless to me when that accursed buffalo endeavoured to kill me? You laughed at what you called my superstitious beliefs-what do you think of them now? However, now that I am certain, my mind is at rest. She is nothing to me, for I can get plenty of younger and prettier women in every village to which we go. As for a wife, when I return to my own kraal, I shall 
marry a woman who is both old and ugly, and who, instead of frittering away her time in love-making, will spend it wisely in preparing food and pombe for me. After all, what else does a man want a wife for ?'

Ere many weeks had elapsed, Malingum had recovered all his old gaiety, and it was cheerful to hear his wholesome laughter and light-hearted chatter in the camp once more.

In explanation of the above episode, let me state that the idea is firmly imbedded in the mind of every native hunter of these parts that, if an elephant or buffalo charge him without provocation, or if his gun hang fire in the chase, it is purely and simply because his wife is proving unfaithful to him. Should such an incident occur when he is hunting, he usually returns at once to his village, calls the villagers together, accuses his wives, and subjects them to the poison ordeal, a description of which rite I have given in another chapter. 


\section{CHAPTER XXVI}

\section{MY TWO WILD DOGS}

ONE day, when tramping after elephants through primeval forest, near the Lukumbuli stream, I came upon a pack of wild dogs, which, as wild dogs usually do, barked, and slinking off to a safe distance, inquisitively awaited our approach, only to disappear again as we came up to them. All at once, Simba, my tracker, calling my attention to a peculiarly subdued yelping, said :-'Bwana, I hear the wild dogs' pups!' and, listening intently to ascertain their whereabouts, we finally came to a lair made by the imbavie in which the dogs had taken up their abode. As we hadn't discovered elephant spoor and our time was our own, I decided to try to unearth these pups, but the task was more onerous than we had anticipated, and it took us two days to dig down to where they lay. Selecting three of the ugly little devils, who, by the way, gave off a most pronounced and disagreeable odour, 
I took them back to camp with me, resolved to make an attempt to domesticate them.

In this effort I only partially succeeded, for even when on their best behaviour, they evinced unmistakable signs of their wild nature, and their odour remained unchanged to the last, surviving repeated attacks of the strongest of scented soaps. I used to call them to food with a cry resembling their own eerie howl, when prowling at night among the mysterious shadows of the forest, and they soon learned to come at once in response, but during feeding they reverted to wild animals pure and simple. Their diet, by the way, from the puppy stage, consisted solely of meat, in fact, they would touch no other kind of food, and as they were particularly fond of young, fat hippo, I have occasionally shot these animals in the Rovuma River on purpose to give them a treat.

After three months of 'civilization,' the first, through some cause unknown to me, sickened and died, and when eighteen months old, the second picked up poison and came to an untimely end. The third, whom I called Jumbo, I kept for more than two years. He became a great pet of mine, and, considering his ancestry and nature, conceived an extraordinary affection for me, assiduously following me out on my hunting expeditions, and often, at evening, in camp, rolling and jumping about 
me in an unmistakable invitation to join his play.

On one occasion, he fell ill, and as I was setting out from camp on a hunt, I decided to leave him behind in charge of some of my men, hoping that with rest and plenty of good food he would recuperate. On my return, about a month afterwards, Jumbo was delighted to see me, and having thoroughly recovered from his indisposition, came running up to me in a state of wild excitement, licking my hands and scampering round me and through my legs for sheer joy, but I had not been long in camp before I learned that he had developed a very nasty temper towards my natives. Apart from the fact that he had bitten two of them, and there was a chance of blood-poisoning ensuing, my head man informed me that my natives threatened to leave me if I kept the dog. Now, on setting out from camp, I had left fowls for Jumbo's food, and told my natives to snare quails, pigeons and guinea-fowls to supplement this diet, but I felt certain that Jumbo had seen little of these luxuries intended to restore him to health, and had been illtreated into the bargain. So I forgave him his sins, and having cajoled my men into a better frame of mind, things ran smoothly once more. But alas! Jumbo's very faithfulness to me brought about his end, for, one day, a native, when approaching me, 
sharply threw up his hand in a military salute, and my dog, who was standing by me at the time, doubtless mistaking this action of the native for a preliminary to striking me, flew at him and seized him by the jaw, tearing him very badly. There was nothing else to do but have poor old Jumbo destroyed! I hadn't the heart to shoot him myself, so commissioned one of my men to perform this act for me, but his death upset me, and, even now, the memory of this wild pet of mine is green in my mind.

The natives, without exception, say that lions will never come near wild dogs, and there may be some truth in this, for a pack of them would prove a formidable foe to any beast of the forest. They are very swift and almost tireless, and their fangs are peculiarly adapted for tearing their prey to pieces. I once saw a couple of wild dogs pursue a hartebeeste, and they kept pace with this fleet beast with the greatest of ease, every now and then springing at and plucking a mouthful of living flesh from its flanks. I shot the hartebeeste, and, scared by the report of my rifle the wild dogs promptly bolted. 


\section{CHAPTER XXVII}

THE GENTLE ART OF POISONING

The African native is a past-master in the art of poisoning. The practice is so common that his outlook on life is always tinged with a fear that, at any moment, he may fall a victim to this death that gives no warning of its approach. $\mathrm{He}$, therefore, takes every precaution to prevent an untimely and painful end at the hand of a treacherous enemy, who, suffering from some real or imaginary wrong, has no compunction in doing him to death, while seemingly on fairly friendly terms. For instance, when a native on a journey comes to a village and begs a drink of water or beer, he always waits until the donor drinks first as a pledge of good faith; and he will never partake of a dish of food, until the host has eaten some beforehand.

To the average European, who probably labours under some misconception that the negro is stupid, the almost devilish cunning with which he removes an enemy without incurring any risk to himself, will 
come as something in the nature of an eye-opener. Let me briefly describe the modus operandi which is often adopted, and, after perusal, the reader may draw his own conclusions as to the quality of mind necessary to originate such an ingenious plan of murder.

Suppose Mputa is labouring under the idea that Manjora has wronged him. Open murder is out of the question-it may be a more manly method of getting rid of him; it is certainly crude, and impolitic. Life is dear to Mputa, and he is most averse to endangering it over such a nonentity as Manjora : therefore, he must poison him. The first step in the undertaking is to procure the necessary poison without rousing suspicion, and this is managed very cleverly and simply; he persuades a friend, Usufu, living in a distant village, to get the commodity from a medicine man there. This effected, he arranges with another dear friend, Hamice, to perform the delicate and difficult operation of administering the deadly stuff, and Hamice, being quite friendly with Manjora, can carry out this portion of the scheme without rousing the suspicion of anyone, and is, moreover, not at all averse to becoming an accomplice in the crime, provided Mputa assures him of a quid pro quo when the painful death of that heathen Manjora has become a thing of the past. There is no prick of conscience 
to disturb his rest, for he has no belief in an avenging deity, nor any lucid conception of a hereafter, and the only thing that troubles him is the risk of discovery, a catastrophe which he employs all his skill to avoid.

The preliminaries all settled, Hamice finds that Manjora is such a good fellow that it is distinctly a duty to ask him to a quiet meal. This, however, is most discreetly done ; there is no necessity to make any definite appointment with regard to the affair, and over such a ticklish operation time is not a matter of consequence. So it happens that Manjora chances to pass one day as Hamice is waiting to partake of food that his wife is preparing, and, in a most casual way, Hamice asks him to share the meal. Manjora, being hungry, accepts the invitation, and Hamice immediately repairs to the spot outside the house where his wife is preparing the food. From her hands, he takes the dish and, carrying it through the hut to where Manjora sits on a mat in pleasurable anticipation of a savoury meal, on the way inserts a portion of the poison into the dish of food, taking particular care to note the exact position of the lethal stuff by some distinct mark on the platter.

'Come, let us eat, friend,' he says jovially, as he puts down the food between himself and Manjora, and soon they are eating and chatting, as if nothing 
at all were the matter. Manjora, having done justice to an excellent repast, and made a clean job of his side of the dish, is doubtless inwardly thinking that Hamice's wife is a most dainty cook. $\mathrm{He}$ has not the slightest suspicion of the treacherous game that Hamice has played on him, for the poison which he has swallowed is absolutely tasteless. Some of the food still remains on the dish and Hamice, to put an artistic touch to the whole drama, passes it over to his own children, bidding them eat and be strong, which they do with alacrity, and the whole fiendish deed is accomplished.

About an hour or so afterwards, Manjora, who has left his friend and gone on his way, feels an irresistible desire to sleep, so adjourns to the shelter of his hut. There, he begins to suffer from an unquenchable thirst, and is subsequently seized with acute internal pains, which leave the poor fellow writhing in agony. A little while after he is no more.

Should any suspicion attach to Hamice, he can easily prove his innocence; for did not he and his own children partake of the very same food as Manjora? Besides, why should he do Manjora to death? He bore the man no ill-will; on the contrary, he was one of his best friends.

Some moriths afterwards, Mputa, the hidden and 
moving spirit of the whole piece of diabolic treachery, meets Hamice, recompenses him for his kindly assistance, and together they drink pombe and indulge in a hearty laugh at the way in which that fool Manjora thoroughly enjoyed his last meal.

There are many ways of poisoning, and I should like to describe another method sometimes used as an alternative to the above, which is also conspicuous for the clever manner in which the perpetrator avoids all suspicion, the poisoner, however, in this case, doing his own dirty work. Procuring little sharp stakes, he hollows the points and inserts poison into the cavities, the poison generally used being that made from the ujungu tree, perhaps the most deadly of the various poisons known to the native and the particular kind that they apply to their spears and arrows. The next move is to insert the little stakes at a slight angle to the path which leads from the enemy's hut to his garden and await results. Sooner or later, the intended victim slightly lacerates his foot with one of these sharp stakes, and being accustomed to scratches, takes no notice of the matter, but ere many minutes have passed, his foot and leg begin to swell, and in an hour or so he expires in great pain. Both the victim and his relatives know exactly what has happened, but, as the whole plan. 
has been carried out with the utmost secrecy, there is very little chance of the culprit being discovered and brought to justice.

The above practices are known to few, if any, Europeans living in those parts of Africa in which they obtain; and the reader may naturally wonder how I have managed to become acquainted with them. Let me explain. During my ten years of hunting, I have been in many life and death escapades with my trackers and men, and, as the reader can see by my narrative, we have again and again pulled one another out of a tight corner. This fact alone is apt to breed an intimacy of thought among men, however diverse the races to which they may belong. Besides, I speak their language as fluently, perhaps more fluently, than I do my own, and often, for the very sake of companionship, I will let drop the strict sense of master and man, and joke and laugh with them in a familiar way. They appreciate this without taking any advantage of it, and when in a communicative mood, tell me things that intimately concern their private lives, a subject which they rarely, if ever, touch upon with a European.

I shall now set down a list of the more virulent poisons generally used by the natives, either for personal revenge, for poisoning arrows and spears, or for use in the poison ordeals. 
The most widely used is that brewed from the inner bark of the mwavie tree, of which there are two species, very similar in appearance, the one being distinguished from the other by a slight difference in the leaves. The commoner species of mwavie is used for the poison ordeals, and the effect depends upon the quantity administered, a small dose causing death, but a large one only inducing violent vomiting, which obviates a fatal issue. The other species (also extracted from the inner bark of the tree) is used by the tribes inhabiting the regions about Lakes Nyassa and Tanganyika, and is called lepunganonie by the Angoni. A dose of this poison means certain death, but it has this distinctive quality - when inserted in native beer and left for two or three hours, it imparts a reddish tinge to the liquor and thus discloses its presence. The powdered bark, however, is almost colourless and tasteless, and, when mixed with food, defies detection.

Another most virulent poison is procured by reducing the roots of the manyanga shrub to a powder, but it has one defective quality as far as its use by natives is concerned, i.e., it exudes a most obnoxious odour. Unfortunately, it is so deadly that a small dose mixed in beer or food may pass undetected, and death will ensue in about two hours after consumption. 
From the roots of a creeper, called letaegaera by the Angoni, the natives extract a most virulent poison, which will prove fatal in about an hour, the effects of the poison being peculiar in that, prior to death, it causes paralysis of the nerve centres affecting speech.

Another largely used poison is distilled from the blossom of the strophanthus shrub, the natives about Lake Nyassa calling it combe. An infinitesimal dose of this drug is used in European medicine as a cardiac stimulant.

That great enemiy of the native, the crocodile, also adds indirectly to its list of native victims by its own death, for its gall, when dried in the sun and pulverized, makes a most deadly poison.

There are many poisons used by the natives for their arrows, poisoned stakes, etc., but of all these, by far the most deadly is that obtained from the ujungu tree. This tree, found chiefly in the Mhega district of the Wangindo country, German East Africa, is of a peculiar whitish colour, and of so deadly a nature that only certain natives will venture to cut it, for a splinter causes terrible inflammation and often proves fatal. It seems as if Nature has mercifully restricted these trees to very distinct localities, and, unlike other trees, they are neither plentiful nor beautiful. This being so, natives will travel hundreds of miles to purchase 
this poison, to procure which, the tree itself is burnt and the ashes mixed with water. This mixture is then boiled down until it is highly concentrated and of the consistency of thick paste, when it is ready for use. Native hunters use it for poisoning the bullets which they fire from their muzzle-loaders. First, they dip the bullet in the poisonous paste, then, to keep the poison in place, bind the missile with very fine twine, and dip it at once in boiling bees-wax. When such a bullet penetrates game, a certain amount of the poison is naturally carried into the animal, and I can only ascribe the huge scars that I have at times discovered on elephants that I have shot to the brutally cruel effect of these poisoned projectiles. The natives say that neither moths nor snakes will venture near this deadly tree and that birds never rest in its branches. 


\section{CHAPTER XXVIII}

\section{TWO LEOPARD STORIES}

Lake Nyassa is, for the most part, surrounded by high hills, which send down ridges and ravines almost to the water's edge. The land between the mountains and the actual lake being very fertile, the natives settle there in great numbers; in fact, the whole of the eastern shore of this expanse of water may be said to consist of a continuous line of villages. Rice gardens flourish along the margin of the Lake, and other gardens lie behind them and stretch back to the hills. All this country forms an ideal home for the leopard, for he can pass the day in the cool shade of the deep gulleys, and at night steal down to the villages to look for the dainties he loves so well-especially sheep, goats, dogs, and fowls.

Some time ago, I was encamped at Chingomangie's village, near the Lake shore, and had with me, at the time, a flock of thirteen ducks. In the light of good old superstition, an adverse fate was bound to cut short their career, and, to assist fate in the matter, 
the district abounded with leopards. For greater safety, I used to pen the birds at night in a large box, which I kept quite close to my tent; but in spite of all my precautions, I discovered, one morning, that they had all disappeared. Having heard no noise during the night, I came to the conclusion that the birds had managed to find a way out of their pen and strayed, and immediately sent out my boy in search of them. He returned shortly afterwards, saying that he had discovered them all dead in a patch of bush, not far from my camp, and following him to the spot, I found his story correct in every detail. The whole thirteen were there, nearly every one minus its head, while on the soft, damp ground between my camp and the patch of bush, we could clearly see the spoor of a leopard. It was evident from the impressions of his feet that he had made a separate journey for each duck, and there is little doubt that he had seized the birds by the head to prevent them creating the slightest noise.

I laid all sorts of traps to entice that leopard back to my camp, but he was a wily brute, and never gave me the chance of putting a bullet into him.

At this time, I had a bull-terrier, called Brandy, whom I had reared from a puppy. He was a perfect specimen of his breed, and on one occasion, at Blantyre Dog Show, carried off the first prize for his class against all British Central Africa. I was ex- 
ceptionally fond of the dog, and wherever I went on my hunting expeditions always took him with me, chaining him at night to one of my tent-poles, lest he should be carried off by a lion or a leopard. One night, it was a night of glorious tropical moon-

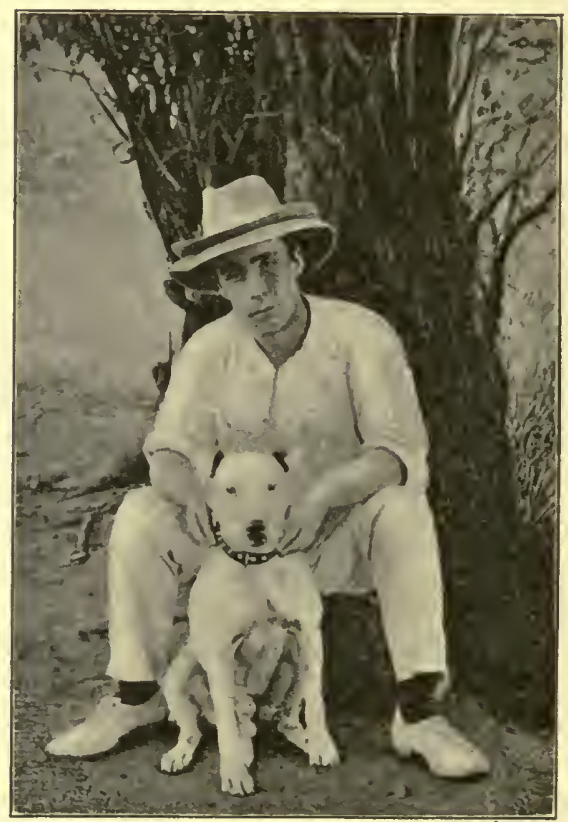

THE AUTHOR'S BULL TERRIER 'BRANDY'

shine, I had him chained in the above manner at the door of my tent, while quite close to the tent was a fire by which sat a watchman, who replenished it throughout the night as it burned low. I had also arranged cut thorn bushes in such a way that any prowler of the night would have to pass close to the 
fire ere he could reach the door of the tent, and feeling that everything was secure, had gone peacefully to sleep. I was awakened, some hours later, by the yell of a frightened human being and the snarling growls of a leopard. Instinctively seizing my magazine pistol, which I always keep under my pillow, I jumped out of bed to find a leopard and my

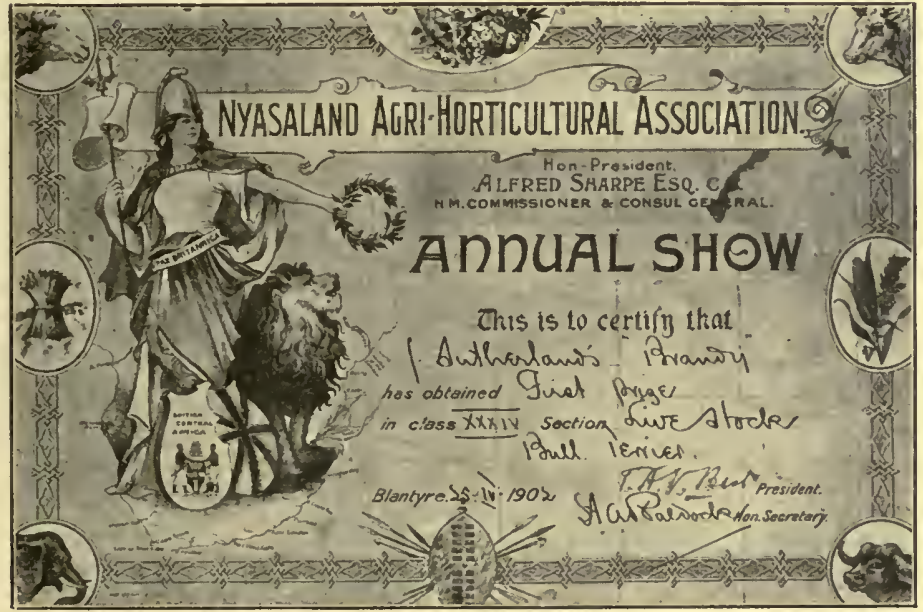

bull terrier in the throes of a fierce encounter, the faithful watchman having long since made himself scarce. Now, Brandy was endowed with all the pluck and fighting instinct of his breed, besides being fully trained to take care of himself, and at the very outset of the combat had, with his usual tactics and extreme quickness, managed to fasten his teeth into the side of the leopard's neck. There he hung, on like grim death, his own neck being 
fortunately protected by a broad, brass-studded collar. Afraid of wounding my dog, I fired two shots in quick succession into the leopard's hip and instantly another into his shoulder; but these failed to give him his quietus, and the conflict continued as fiercely as ever. As they writhed and fought, I could see every movement of the leopard in the bright tropical moonshine, and seizing the first favourable opportunity, sent a bullet through his heart, instantly killing him. Even then, Brandy clung to his opponent, as if determined to avenge himself for the mauling he had received, and it was some time before I could coax the plucky dog to loosen his hold. When I did so, I found that my bull-terrier's chest and left hip were terribly torn by the leopard's sharp claws. Very gently I cleaned, disinfected and stitched up the warrior's wounds, and made him as comfortable as his injuries would permit, but so badly had he been lacerated in the struggle, that it took him two months to recover thoroughly from the effects.

Poor Brandy! he afterwards succumbed to that bane of tropical Africa, the tse-tse fly. At the time of his death, I happened to have a store in the district for the purchase of rubber, bees-wax, etc., from the natives, and wrapping up the remains of my poor old friend in a roll of cloth, I buried him in a hole in the earthen floor of the same store. So 
upset was I at losing my chum, that, somehow or other, that store all at once became intensely obnoxious to me; it symbolized the unhealthy district and the dreaded fly that had accounted for poor Brandy, so putting a match to the place, I sent it with its stock of goods and chattels heavenwards in smoke and flame-a funeral pyre to as fine a dog as anyone could have wished to meet. I left the district the same day and have never returned. 


\section{CHAPTER XXIX}

MAHOMETAN FAITH AND ELEPHAN'T MEAT

The Mahometan, as is well known, never partakes of the flesh of an animal that has not been killed by cutting its throat with the usual formalities prescribed by the religion, and, of course, the elephant, like the pig, is one of the animals that is taboo among the followers of the Prophet.

Some time ago (it was in October, 1907), I witnessed a most amusing spectacle in which temptation and faith engaged in a bitter struggle for mastery, a spectacle which might have served to illustrate an old saying inverted-' the flesh is strong but the spirit is weak.' At the time of which I speak, I had among my men several who were pure and unadulterated heathens-and splendid fellows to boot! On one occasion, the day after I had shot some elephants, these happy pagans were making a good meal on the fat, juicy flesh done to a turn over a clear, wood fire, when several natives of the Wangindo tribe, Mahometans by faith, came 
upon the scene and stood spectators of this goodly repast. For a while, they watched the eating unmoved; then the savour of the cooked flesh, making a swift onslaught on their most sacred beliefs, they grew hesitant ; and, finally, after a brief consultation, arrived at a unanimous decision. Elephant meat had won the day, and they came forward, saying that they had been foolish long enough in adhering to such an austere faith, and henceforth were going to consume whatever food the gods sent them and elephant meat in particular. So sitting down, they joined my men's feast, toasting and eating and making merry over the savoury flesh, while the Mahometan faith was relegated, for the time being, to the region of unpleasant memories.

In the midst of this rude but cheerful banquet, there appeared on the scene an old man, wearing under his arm a board on which was written a Mahometan prayer, a custom followed by many devotees of that faith, and after the usual salaams had been exchanged, one of my men jokingly asked him to join the repast, never for a moment dreaming that he would do so. At first, the old man emphatically refused, and, as if afraid that proximity to such impiety would defile him, went and sat down a short distance away and closely watched his degenerate brothers, who had so weakly lapsed into 
heathenism. Whether he was "pitying them and offering up a silent prayer on their behalf, I do not know, but, with man's frail nature, looking temptation in the face is admittedly an unwise proceeding, and when the old fellow asked the feasters what the meat tasted like, and whether it was tough, I felt that the ice of his asceticism was beginning to thaw in the sunshine of their epicureanism, and pondered on the insatiability of human curiosity as to the nature of $\sin$ ! My men replied that it was delicious, and Ntawasie, my tracker, playing the good old rôle of tempter, coolly took a steak that he was toasting over the fire and offered it to the old man. He looked at it with a gaze in which desire and renunciation were curiously blended, and muttering something about being insulted, rose, walked away a few yards, and once more sat down. Thereupon, my boy, Usufu, went up and chatted.with him and gave him a pinch of snuff to soothe his wounded feelings. After so long an exposure to the appetizing odour of roasting elephant meat, that friendly pinch of snuff proved his undoing, for, a few seconds later, he sprang up and excitedly shouted:

'Yes, the temptation is too great for me! Why should I continually deny myself the pleasure of : eating this delicious meat, because it has been forbidden by the Mahometan faith? No, I'm sick 
of the faith, and am finished with it now and forever!'

With these words, he took his prayer-board from under his arm, broke it in pieces, and flinging the fragments on the fire, sat down to a right royal 'tuck in,' while my men, most of whom are Mahometans from the coast, and the Wangindos, unable to resist the humorous side of this little tragi-comedy, simply rolled in the sand and yelled with laughter.

I'm afraid that the Mahometan religion has lost many of its adherents in Africa owing to the temptation of elephant meat, for I have, on many occasions, been present when this taboo and the teaching of the Prophet have fought a pitched battle in the arena of a native's simple soul, to the complete discomfiture of Moslemism. 


\section{CHAPTER XXX}

\section{A FEW THRILLS AT BANGALLA RIVER}

In 1907, whilst hunting in the neighbourhood of the Lumasuli River, a tributary of the Rovuma, I had become friendly with an old Macua native elephant hunter, called Makakora, and during one of many conversations on the game that was so closely bound up with our lives, he urged me to pay a visit to the Bangalla River where, he assured me, good sport was to be obtained. He promised to conduct me to the elephant district there, simply for the pleasure of seeing a few elephants killed to avenge the deaths of a couple of his hunting companions, who had, some years ago, met their fate in the chase in that locality. Won over by his glowing assurances, I resolved to give the place a trial, and as this narrative will disclose, was not to regret my decision.

Reaching the Bangalla River about the middle of December, an excellent month for hunting, I formed my main camp at Karanji's village, and got 
away to the pori (forest) to try my luck, but, disappointed at meeting with no fresh elephant spoor during the first three days, I decided to return to camp and provision my party for fifteen days, a period which would enable me to scour all the country towards the source of the river near the Kibali Hill.

But the best laid schemes of mice and men gang aft agley! We had just left a small water-hole in the neighbourhood of which we had slept overnight, and were hopeful of reaching camp in a few hours, when, to our intense joy, we came across the fresh spoor of three large elephants. Broken branches, the freshly expectorated fibre of chewed hemp leaves, as well as the presence of comparatively warm droppings, gave us unmistakable evidence that they had passed by quite recently, so we fell into our customary formation and followed the spoor. After about an hour's tracking through seemingly interminable glades of tall dry grass and rustling bamboos, we all at once came up with our quarry, standing in a group, their dark, hulking bodies clearly discernible through the interlacement of vegetation. One of them, as if lost in elephantine meditation, was standing in a beautiful position for placing a shot; the other two, quite heedless of the approaching danger, were placidly feeding among the bamboos. I took most deliberate aim at the 
first, and instantly dropped him with a solid 577 bullet in the brain. He never budged again! I promptly emptied the second barrel into one of the remaining two, but as I had slightly miscalculated the vicinity of his heart, owing to intervening bamboos, the bullet struck him too far back, and like lightning, he made tracks for a dense belt of bush in our rear and from which we had just emerged. The third animal, scared by the first shot, had already made good his escape, so handing my heavy rifle to my tracker, Malingum, I caught my $10.75 \mathrm{~mm}$. from my other tracker, Simba, and dashed after the wounded elephant. Now, several hundred yards on the other side of the same patch of bush, my carriers, having laid down their burdens and moved some distance away from the spoor, on hearing the first shot-a plan I invariably make them adopt for their own safety-stood awaiting developments. On seeing the elephant suddenly emerge from the bush into the open country in which they had come to a halt, they began to shout in the hope of turning him, and the animal, thoroughly scared by their lusty yells, immediately changed his plans, slewed round, and came running back at a great pace towards the friendly cover of the thicket of bamboos. At this juncture, my trackers and I, unaware of what had happened, although we had 


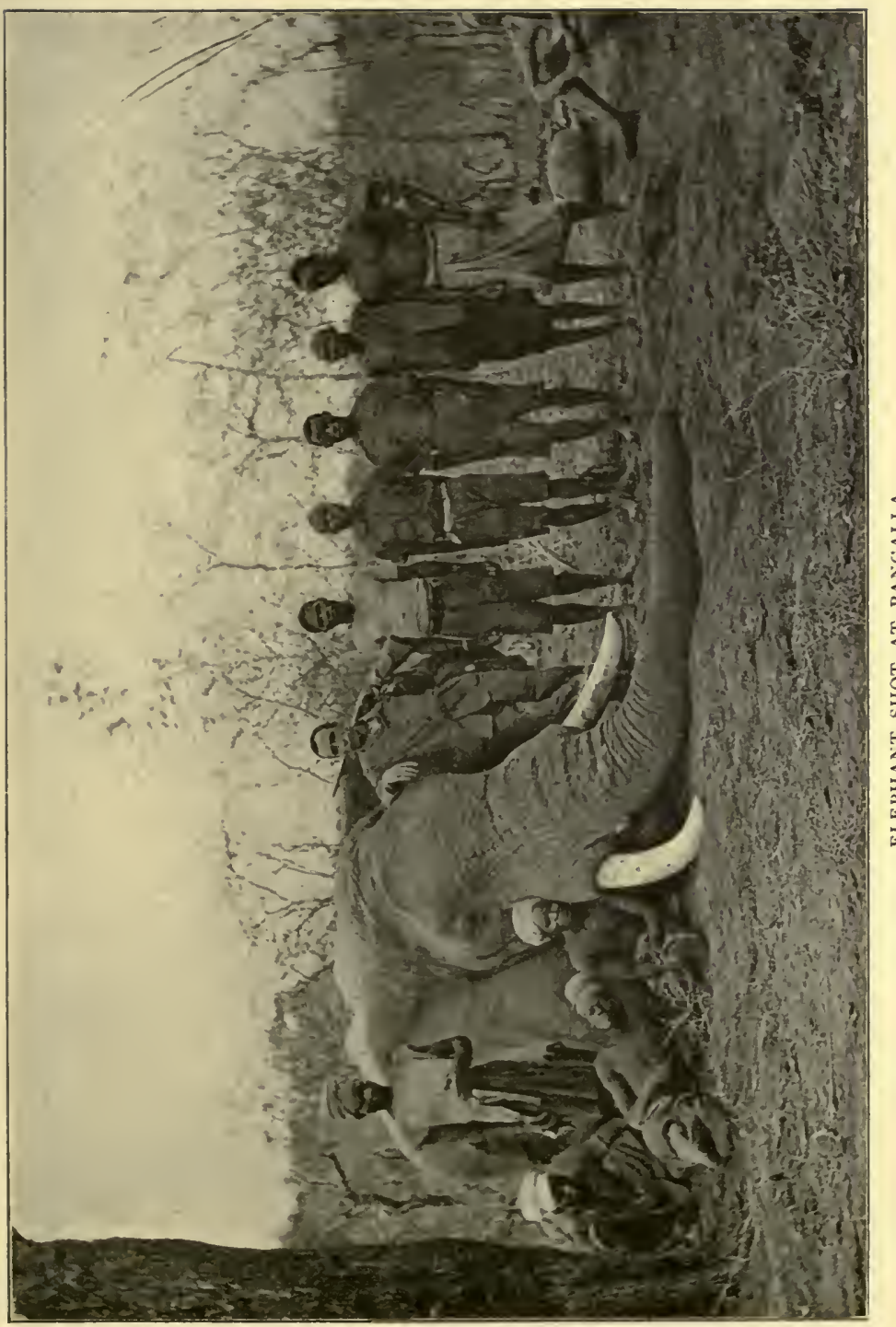

 
heard the yells, came out of the thicket at a sharp canter, and you can judge of our surprise when we saw Behemoth thundering down, straight as a die, in our direction, with the disconcerting momentum of a locomotive! All at once, he caught sight of us, and, dismayed at the unexpected encounter, pulled up and stood stock-still, as if hesitating what to do. Recognizing that he had, to put it metaphorically, got between the lines of the enemy, he decided to give battle, and, uttering a shrill scream, charged straight at me. When he was about sixty yards distant, I fired in his face, the bullet, however, penetrating his skull a little too high to reach his brain. Instantly pressing another cartridge out of the magazine into the breech, I fired and struck him in the forehead; then another; but for all the effect they had, I might as well have fired them into an advancing battleship. On he came as fast as ever, with lowered head and unmistakable purpose! Jerking my last cartridge into the breech, and instinctively dropping to my knee, I pulled the trigger, the bullet striking him a little above and right between the eyes, and smashing through skin and skull into his brain. Down he fell with a crash, and lay only seven measured paces from where I stood!

During this excitement, the old hunter, Makakora, who had followed up close behind me 
to watch the actual avenging of his comrades, on seeing three bullets fail to stop the elephant, had completely lost his head, and uttering a terrified yell, had, to put it gently, beat a hasty retreat. In his wild career, he unfortunately tripped over the protruding root of a tree, and with a loud imprecation fell headlong to earth. He severely sprained his ankle in the fall, but painful as this mishap undoubtedly was, he had, after the danger was over, to suffer the jibes and jeers of my men, who, having witnessed the whole incident, burst into roars of derisive laughter over the recollection of the accident, as is their wont when any of their companions get into difficulties. We rigged up a maschilla for Makakora and carried the old fellow back to the village, where a week's rest put him on his feet again.

The tusks of the first elephant shot scaled 75 and $76 \frac{1}{2}$ lbs., respectively; those of the second 62 and $69 \mathrm{lbs}$. One of the ears of the latter animal was badly frayed, the result of native bullet-holes, having been torn and enlarged by branches when the beast was forcing his way through the bush. Both animals bore the scars of many old and recent bullet wounds inflicted by native hunters. 
II.

A couple of days after the incidents related above, we followed up the spoor of four more elephants and succeeded in coming up with them, but in such

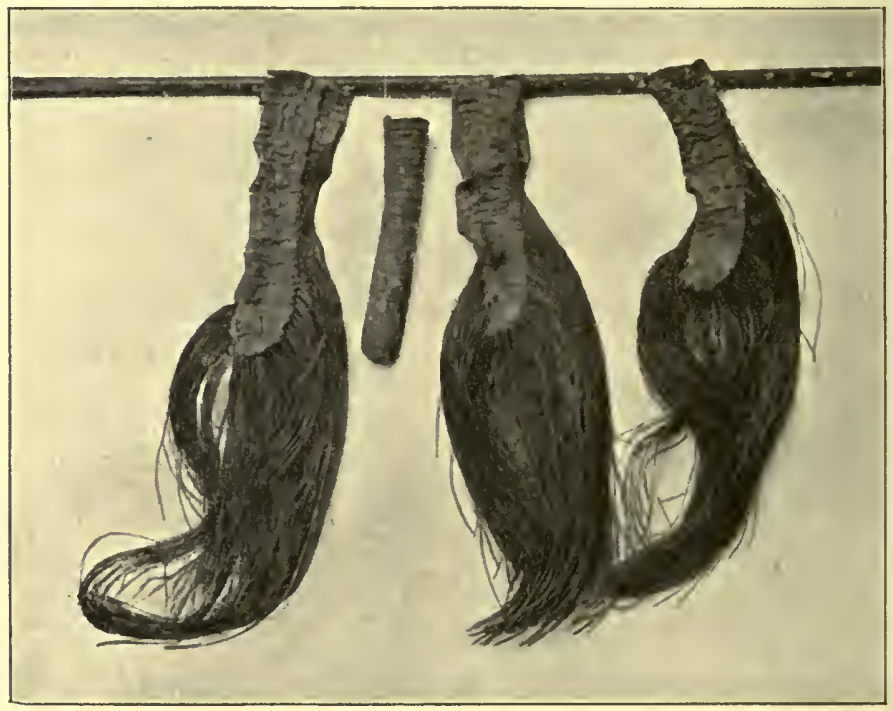

THREE VERY FINE ELEPIANTS' TAILS, AND ONE ABSOLUTELY DEVOID OF HAIR.

dense bush that, though we could hear them bursting their way through the growth, seeing them was well-nigh impossible. In the midst of this exasperating state of affairs, the wind suddenly veered round, gave them our scent, and sent them crashing off through the jungle at a tremendous pace. Twice again, we came up with them, but the 
amazing luxuriance of the vegetation hid them from us as completely as if they had been separated from us by a stone-wall, rendering tracking a painfully slow and dangerous operation. To add to the excitement, a thunderstorm now broke over our heads, flash after flash of vivid lightning illuminating the impenetrable tangle of the jungle in a devilish glare, followed by crash after crash of thunder. Down came the rain in a deluge, hissing and splashing and pattering among the foliage, soaking us to the skin and chilling us to the marrow, while, in the intervals between the ear-splitting peals, we could hear the elephants moving about in the bush as if they were the presiding spirits of this forest inferno. Then, as swiftly as it had approached, the storm moved away; the lightning grew more and more intermittent, the growls of the thunder more and more subdued. As evening was fast approaching, I now told my men that I intended to tackle the quarry, but that, if they again cleared, we should pass the night where we were, and take up the spoor in the morning. Their limbs shaking, their teeth chattering with cold, owing to the drenching they had received, and tired out into the bargain, my trackers clearly showed that they did not hail this decision with acclamation. Being a trifle out of temper, I snatched up my double 577 , and telling them that they were useless to me and had better stay behind and nurse 
one another, I hastened after the elephants. But I had not gone more than a hundred yards, when I heard a rustling in the bush a short distance behind me, and on turning, saw, to my surprise, my trackers hurrying after me.

My head tracker, Malingum, came up to me and said :

'Look here, bwana, it's much too risky to tackle elephants in such dense bush, for if you get near them, you will be quite unable to plant a decisive shot, and should they get frightened and clear in our direction, we run great risk of being trampled to death, as it is well-nigh impossible to dodge aside to avoid their rush in this mass of entangled vegetation. However, if you insist on going, we will follow.'

'Right you are! Come on, we'll go through with it,' I replied, feeling that this was no occasion for leisurely discussion, and pushing on, drew nearer and nearer to the quarry.

As the elephants were now not more than thirty yards distant, it behoved us to use the utmost caution, and it was with every faculty alert, that we gradually crept closer and closer to them along the tunnel they had bored through the thicket. All at once, Malingum, excitedly tapping me on the shoulder, pointed a little to my right, and, looking to where he indicated, I could see the herd standing 
in an open space of about fifteen yards in diameter. Three of them were facing away from us, the fourth was stolidly gazing in our direction as if expecting our approach, although we were to the lee of him. Motioning my men to keep absolutely still, I slowly raised my rifle, but the brute, seeing the movement, advanced rapidly in my direction. When he was within ten yards of me, I fired the first barrel, the bullet striking him a little above the right eye, and finding that this failed to stop him, I again pressed the trigger and gave him the contents of the second barrel knocking him clean over with a bullet right between the eyes. Meanwhile, the others had started in our direction and the foremost, characterized by a complete absence of tusks, uttered a shrill scream and charged us. I dropped my empty rifle, seized another from my tracker, $\mathrm{N}$ tawasie, and blazed in the animal's face. He immediately turned and, joined by his companions, smashed through the bush at headlong speed, sundering the network of impeding branches and creepers like so much cobweb.

I now turned my attention to the first elephant, and finding that he was not dead, gave him his quietus. Reloading my rifle, I went in pursuit of those that had decamped, but in spite of the copious blood spoor, dusk closed in before we could come up with them and obliged us to retrace our weary 
steps to where the dead tusker lay. We pitched our camp within easy reach of the carcase, and, early next morning, cut out the tusks, which were of beautiful ivory and weighed 89 and 87 lbs., respectively.

During the night, however, whilst tossing on

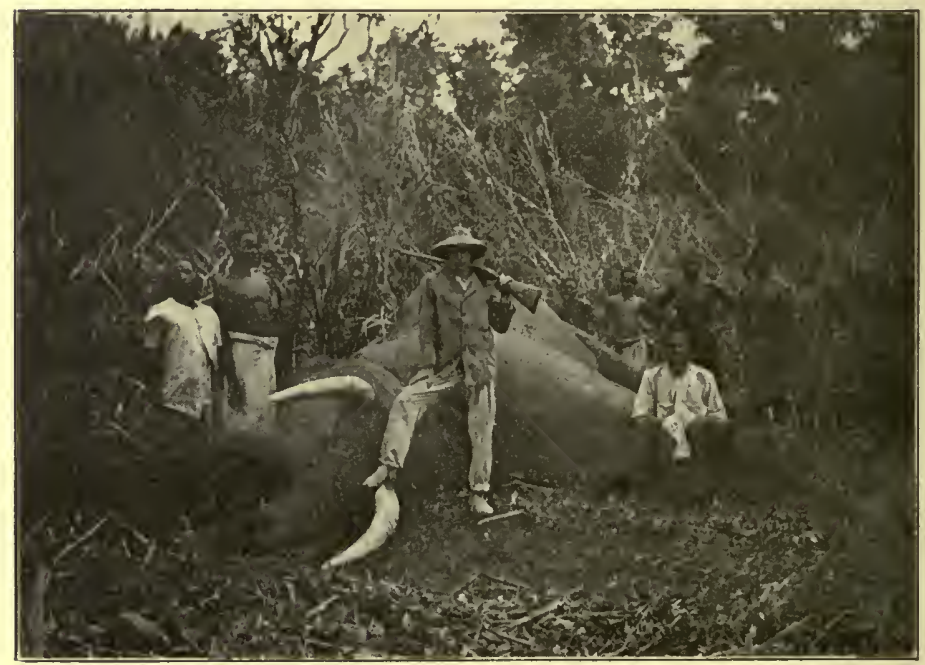

THE DEAD TUSKER.

my camp bed with a touch of fever resulting from the exertion and subsequent drenching of the day, I was all at once roused by a succession of alarmed yells from my tracker, Malingum. Fearing all sorts of contingencies, I picked up my rifle, and rushing to where my man lay, about a score of yards away from me, found him in a state of great perturbation. During the night, a puff adder, 
probably in search of warmth, had crept between the blankets, and Malingum, in turning over, had unwittingly rolled on his unwelcome bed-fellow, and promptly been bitten in the thigh. As the bite of a puff adder is most venomous, and often results in a painful death, it was an occasion for a desperate remedy. Unfortunately, I had neither permanganate of potash with which to counteract the poison, nor caustic to cauterize the wound, so whipping out my knife, I immediately cut the punctured flesh to induce a copious flow of blood, and placing some gunpowder on the incision, put a match to the explosive. Then, pouring out a tumblerful of neat whisky, I bade Malingum swallow it-an order which he obeyed with alacrity-and in half an hour supplemented this genial physic with strong coffee. After the lapse of another thirty minutes, I repeated the dose of whisky, and again alternated it with coffee, and thus staved off the lethal drowsiness that invariably follows snake-bite. Next morning, Malingum, though suffering much pain from a badly swollen leg and thigh, was well out of danger, and, as it was quite impossible for him to accompany us further in the chase, I sent him back in a maschilla made out of his own blankets to camp. In about a week, he had thoroughly recovered from the effects of his painful experience. 
On the night of the mishap, one of my men killed the puff adder that had caused the trouble and eventually presented the skin to Malingum, who, in a spirit of sardonic humour, fashioned it into a belt, saying:-

'You tried to kill me and now I shall revenge myself by making use of your old hide!'

A few days after this episode, while we were in pursuit of three elephants, a peculiar incident occurred. The largest of the three, whose tusks were below the average, only weighing 46 and 48 lbs., each, I shot with comparative ease; the other two, being young bulls with quite insignificant tusks, I left severely alone. Scared by my first shot, however, they had bolted, and doubling back on the spoor, met my carriers who were following me at a distance of about a mile. Being in a dangerous mood, one of these bulls, on seeing my men, charged them furiously and they, dropping their loads with fright, scattered in all directions. Two of the party, who had been carrying an empty maschilla, slightly in advance of the others, were the first to discard their burden and flee for dear life, and the infuriated elephant, catching sight of this object lying in the path of his pursuit, angrily grabbed it and began wreaking his vengeance on it as he bore it along. This operation he performed to his thorough satisfaction-tearing the canvas to 
shreds, crunching the pole in his powerful jaws, and finally flinging the unrecognisable remains of the offending object aside. He had, in all probability, scented the odour of human beings from the maschilla and mistaken it for some portion, or strange species, of the living individual-at least, this is the only explanation of this curious incident that occurs to me.

We had now been fifteen days in the pori, and as our food supply was running low, and we had temporarily had our fill of adventure, I decided to return to camp for a few days' rest. On our arrival, we found that Makakora, whose ankle was now quite well again, was eager to return at once to his home. He gave as reason for this sudden desire to leave us, that he was afraid of the village headman, Karanji, bewitching him; for, some years ago, he had eloped with Karanji's favourite wife, and Karanji, as he explained in a luminous phrase, now loved him as he would a snake. Under the circumstances, it behoved him to make himself scarce, for death by poison or violence would certainly be the price of a lengthier stay in the neighbourhood. He further informed us that he had decided to plunge into the forest and only converge on the direct homeward path some miles from the village, because he feared that Karanji, having become acquainted with his intention to depart, might have arranged poisoned 
stakes along that path in the immediate neighbourhood. Should any of these stakes penetrate his foot, it would mean farewell to his hunting and his women, whom he loved as only a hunter can, and he was, he added, in no hurry to leave this enjoyable world at present.

Makakora, I may mention, had four wives, the favourite among whom he pointed out to me on several occasions. She was a Mwera woman, and after the manner of most women of that tribe, wore a large ivory ring in her upper lip, which caused that lip to protrude in a most unsightly way, about two inches at right angles to her face.

'That is the one woman for me!' he used to say, with pride. 'She is an excellent cook, makes the best beer in the country, and works assiduously in my garden. She is old, no doubt, while my other wives are young, but my young wives do not count ; for they are simply waiting for me to die so that they may seek the arms of their younger lovers. Fickleness is in their blood; it is in the blood of all young women. But their future husbands are welcome to them-I have had their early love.'

When on my way down to the coast, homeward bound, on this last occasion, Makakora made a two days' journey to bid me farewell, bringing along with him two of his young wives, carrying food for 
myself and my men as a parting gift. His last words to me were in the nature of advice on his favourite subject.

'Don't marry young wives, bwana, when you get to Europe,' he said paternally, 'they will only be as faithless to you as mine have been to me!' 


\section{CHAPTER XXXI}

SOME PECULIAR FOODS

When I shoot an elephant within reasonable distance of a village, I usually send a couple of messengers there to purchase food for my men, and eggs and fowls for my own consumption. Shortly, after their return, the headman of the village usually appears on the scene, accompanied by his wives and a horde of men, women and children, all elated at the prospect of gorging themselves to repletion with nyama (meat). On their arrival, my men are perhaps busy cutting out the tusks, so they stand aside and await the conclusion of this operation, which is a tedious work, requiring trained men, for it must be remembered that two to three feet of these enormous teeth are embedded in the skull, and that in extracting them, one careless stroke with an axe may chip the tusk and diminish its value. On the completion of the task, all the natives set to with a will, and, ere long, the carcase is being quickly hacked to pieces. 


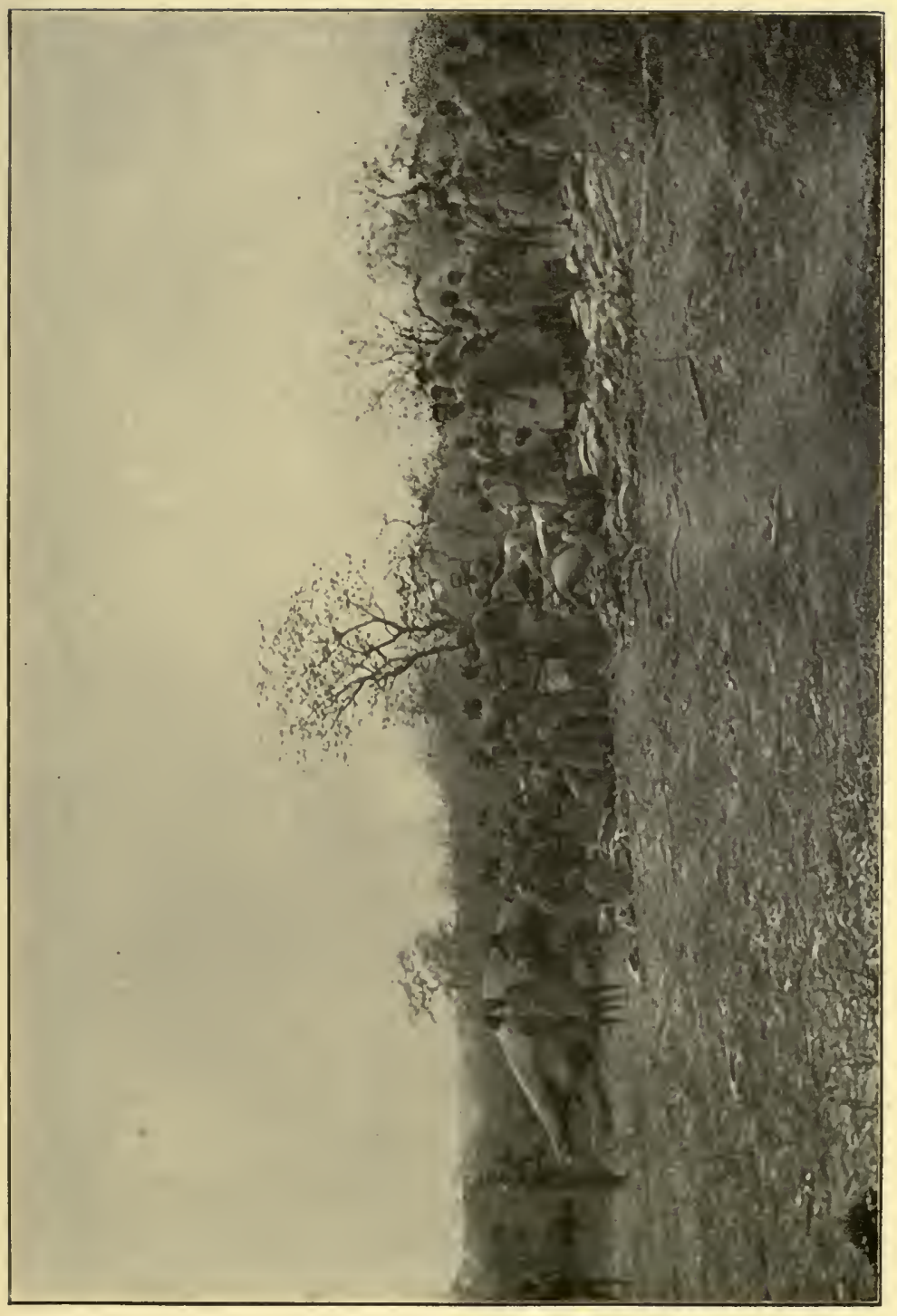

空 
Scores of men, women and children, make merry, yelling, laughing, chattering and quarrelling as they slash and grab at the choicest portions of the meat, while some of the more boisterous spirits get right into the carcase, from which they emerge, later on, in a horrible mess, with bodies smeared and hair matted with congealed blood, and looking more like devils than human beings. The dexterity with which these people use their knives is amazing, and how they avoid severely cutting themselves has always been a mystery to me, for their razor-edged blades are continually criss-crossing and ripping away in all directions in a seemingly reckless fashion.

Although I have read many eulogies on elephant meat as a food, I must say that I think it tough and coarse-fibred and without any flavour of game. The feet make good eating, being very gelatinous, but in my opinion, the trunk is by far the most palatable portion of the elephant. The method of cooking these titbits is curious : a fire is kindled in a large hole dug in the ground, and when it has burned clear, a light layer of earth is placed over the hot embers, the trunk or foot being inserted in this layer and covered with more earth. A huge fire is then kindled over this strange oven, and in about thirty-six hours, the meat is ready to serve. Elephant's heart, toasted, is good, but has, in my 
opinion, been somewhat overrated, and cannot compare with either the feet or trunk. The natives have a method of drying elephant and other kinds of meat by exposing the flesh to the sun during the day and smoking it over a fire at night, after which treatment, it will keep in a satisfactory condition for a considerable length of time. When it is in this preserved state, the natives will eat it without further cooking, but though I have read of certain African tribes eating raw meat, this custom does not obtain among any of the numerous tribes with whom I have come in contact.

Of other kinds of game, young buffalo, inswala. eland, reedbuck and bushbuck are the most "toothsome. The flesh of the rhinoceros is excellent, being of a very fine texture, considering the enormous size of the beast; while hippopotamus meat makes an ideal curry, as the fat and lean are so nicely in proportion.

Among their various foods, the natives have one which they consider a special delicacy, although I am afraid it would hardly appeal to a civilized palate. This is a maggot, some three inches in length, which they call the maungo, and which bores into and lives in the decaying trunks of the mungo, incunia and tumbie-tumbie trees. It is a perfectly white mass of fat, and I have often seen a native 
woman, after nipping the head off a maungo, give the remainder to her child to suck as a teat.

The natives of many tribes such as the Mwera, Macua, Wangindo and Amatengo, evince a decided partiality for the flesh of puff-adders and pythons. These delicacies are usually toasted on a spit over the embers of a fire, but occasionally enter into the composition of a curry, the principal flavouring ingredients of which are bissari, chillies, ginger and cloves, and these constituents (excepting of course the puff-adder and python) are used by my cook in preparing a curry for myself.

The Upanga and Ubena, two tribes living to the north-east of Lake Nyassa, are extremely fond of the flesh of dogs, while porcupines are considered a delicacy by many natives, who dig the animals out of their holes and spear them. I have often eaten porcupine flesh and consider it an excellent food.

The natives of many tribes among whom I have lived are very partial to ants, using them for food only in the rainy season when they are winged. They either eat the insects alive, after plucking off the wings, or crush and mix them with water or monkey-nut oil, and having stewed the resultant paste over a fire, use it as a relish. There are several varieties of ants, but they all go under the Mahometan name of njeremba.

The Atonga and Sokeri tribes, dwelling about the 
western and northern shores of Lake Nyassa, capture myriads of small midgets that come in clouds on the wind, and make a kind of cake from the dough procured by crushing the insects. In the same category, may be classed locusts, which are eaten by most native tribes, who, after plucking off their wings, fry and devour them. I have tried locusts fried in butter, as an experiment, and found them not distasteful.

Many of the native tribes dwelling near rivers and lakes show a decided penchant for crocodiles' eggs, which equal those of a duck in size, and are to be found in the sun-warmed sand near the water.

Wild honey, of which there are several kinds, is eaten by almost all the native tribes with whom I have come in contact. First, comes the honey, called asari, obtained from the hive of the ordinary wild bee and closely resembling in flavour the honey produced by the garden bee in the Old Country. Second, I would rank that of a small midget which makes its hive in the cavities of trees.

This honey, called by the most tribes insoma, but by the Angoni, chingwaengie, has a most delicious flavour with a faint odour of musk-just a delicacy for the epicure. Another kind, called lecama and resembling insoma in flavour, is the product of a larger midget which makes its home in ant-hills. 
Lepalie is the name given to a honey found in the hollows of trees and gathered by a fly a little larger than the ordinary house-fly. Another fly, called lependura, and almost identical with the ordinary house-fly, secretes a deliciously-flavoured honey in the earth.

The tuberous roots of a forest creeper, called hanguy, are used by the natives when short of other kinds of food, but a lengthy process of preparation, resembling that used in the manufacture of tapioca, is necessary before they are edible. After boiling for about two hours, the tubers are peeled and sliced, and the slices are then boiled for about eight hours, after which they are dried in the sun and ground to a flour. Hanguy roots are very poisonous, and unless the poison is thoroughly extracted, death usually supervenes about two hours after the unfortunate consumer has partaken of them, the patient losing his power of speech and behaving as if he had been bitten by a snake.

Acca is the name given by the natives to a small, green shrub, which grows about a foot in height, and bears a pale green fruit of a pleasant, sweetish taste. The fruit is boiled and skinned. The remaining kernels are then allowed to simmer from eight to ten hours, and are afterwards dried in the sun, but preparatory to consumption, they must be boiled again for another hour, in order to soften 
them. Before the above process, the fruit of the acca is a slow poison : severe stomachic pains follow on eating them, and death ensues in about ten hours.

In times of lean harvests, the itching buffalo bean, called by most tribes the upupu, by the Angoni, chepungu, and the Wyao, lequania, is prepared and used as an article of food.

A species of wild potato, called by the Mwera, matuku, and by the Angoni, mepama, is found in the bush. It is perfectly white in colour, almost tasteless, and of the same texture as an ordinary potato. The method of cooking is exactly similar to that adopted in the case of cultivated potatoes.

Msindaeka is the name given to a herb closely. resembling spinach, of which there are several wild varieties, while many kinds of grass such as timbaweesi, mlinda and kalialikamoschie are prepared and eaten as vegetables. 


\section{CHAPTER XXXII}

THE LORD OF THE RIVER

Next to the lion, comes the crocodile as a perpetual menace to native life. The average black man, too, is so careless and so imbued with fatalistic ideas, that thousands of them are annually killed by these monsters of river and pool, when the exercise of a little caution would obviate the majority of such fatalities.

When I was living in the vicinity of the Shire River, in Nyassaland, crocodiles were continually catching and devouring natives-usually womenwho, heedless of danger, came down to the banks to draw water or bathe in the shallow reaches; while at Fort Johnston, on the Upper Shire, an incredible number of natives fell victims to these insatiable reptiles.

At Mpimbi, also on the Shire River, crocodiles actually made a practice of upsetting native canoes, in order to secure the occupants, and it became a favourite pastime of Europeans resident at that 
station to sit with their rifles in wait for these brutes, and scarcely an evening used to pass without one of these amphibians being shot.

Some years ago, I had rather a gruesome experience on the Upper Shire River. I had just returned to camp from hunting in the vicinity, when I was suddenly startled by a tremendous commotion among my natives and those of a neighbouring village, and above the hubbub I could hear the strident voices of men and women, yelling 'Ngwena! Ngwena!' (Crocodile! Crocodile!). Concluding that someone had been taken by one of these monsters, I seized my 303 and rushed to the scene of the tumult. On the river bank, I found a crowd of natives, all jabbering excitedly, and after some inquiry, elicited the information that one of their number, a woman, had gone down to draw water, and while she was in the act of filling her calabash, a crocodile had seized her by the hand and endeavoured to pull her into the stream. Fortunately, the woman had had the presence of mind to clutch and hold on with her disengaged hand to the reeds growing near her and to yell with all her might for help, and luckily, too, the crocodile had been a young one, or she would have been dragged off without further ado. Some men and women, who were in the vicinity, at once rushed to her aid, and catching hold of her feet, strove to 
wrest her from the reptile's grasp. An awful tugof-war now ensued, and in the struggle, the child, which the poor woman was carrying tied to her back, fell into the water. Like a flash, the crocodile let go his hold upon the woman's hand, seized the child in his jaws and disappeared, and the dark, swift waters of the Shire mercifully hid the remainder of the tragedy from the distraught mother's eyes.

Hardly had this awful drama been concluded, when one of the villagers, who at times suffered from fits of dementia and had, on such occasions, to be kept under constraint, appeared on the scene. Brandishing a spear above his head, he kept calling out, 'Where is the crocodile? Where is the crocodile?' and before any of his fellows could restrain him, he had rushed headlong into the river. In a moment, a crocodile seized him by the waist, another by the head and shoulders, and a terrible struggle ensued, crocodiles rushing from all sides, as if eager for the fray-the very water seemed to seethe with them. The native fought as only a madman can fight, but, naturally, such a conflict was bound to be brief, and when I arrived on the actual scene it was difficult to distinguish man from beast. Firing quickly, I managed to kill several of the brutes, but could not prevent the others from dragging the poor fellow under water 
and taking him (as we could see from the commotion beneath the surface of the stream) to the other side of the river.

The hand and arm of the woman who had been seized by the reptile were badly bitten, so I dressed and disinfected the wounds to prevent blood-poisoning setting in, and after repeating this operation for several days the girl was practically quite well again. Strangely enough, on her recovery, she came to me and, to my intense surprise, asked me for a present because I had cured her, a demand which greatly amused me, for, thinking in European fashion, I, somehow, dimly felt that, if the question of presents entered into the affair, I should be the recipient instead of the donor.

One would naturally think that her experience would have taught this girl a lesson, but, in illustration of my remark about the absolute carelessness of natives, less than six months after this occurrence, she and another woman were dragged into the river and devoured by crocodiles at the very same place.

On another occasion, I shot a very large crocodile on the Upper Shire River, and my men, on opening up the reptile's stomach, made a gruesome find in the shape of several native brass bangles, which had doubtless once adorned the arm of some hapless girl whom the brute had seized while she was bathing or drawing water. 
At Mpimbi, there occurred, some years ago, a most extraordinary incident. A native, having just stepped into his canoe and being in a talkative mood, remarked to a companion standing on the bank:- 'Only a week ago, a crocodile killed my mother and some day, I dare say, I shall share the same fate.' With these words he bent down to reach for the pole with which he propelled his canoe. Immediately a crocodile seized him by the arm, and before his friend could even make an attempt at rescue, the poor fellow had vanished into the water, never to reappear.

Once, on the Shire River, a similar tragedy was only averted by the timely presence of a European. As a canoe was being poled across stream by a native, a crocodile thrust his snout over the frail vessel, capsizing it, and, as the occupant fell headlong into the water, seized him by the arm and was about to disappear, when a European (I believe his name was Henderson) who was fortunately on the opposite bank of the river, on the look-out for crocodiles, seeing the native's predicament, at once fired and killed the reptile. The injured man was promptly rescued and taken ashore, where his arm was amputated, and, recovering from his dreadful experience, for years earned his living as a lettercarrier. 


\section{CHAPTER XXXIII}

\section{THLEE SLAVE GIRLS}

When hunting on the Rovuma River, some years ago, I had an experience which is interesting as an illustration of the way in which slave women are bartered throughout German and Portuguese East Africa.

I had just finished lunch, and was enjoying a cigar in my tent, when my private boy came and told me that the Sultan Mperembe, a big Wyao chief, whose people inhabit the country about the Lujenda River, had sent a couple of his men with three slave girls as a present for me, asking, in exchange, a barrel of gunpowder, some percussion caps, and some medicine for killing elephants.

With regard to the last item, let me explain that the native mind is firmly imbued with the idea that it is not due to the precision and power of a modern rifle that a white man kills an elephant, buffalo or rhinoceros, as the case may be; but that his success in the chase is won by the potency of some secret 
concoction that he drinks, or with which he inoculates himself, or by the efficacy of some charm or amulet that he wears. Like many modern civilized people, he is not satisfied with the factors which his senses convey to him as forming definite knowledge; he must have some occult power manipulating the wires and, therefore, every act of his life is tinged with superstition in one form or other. The native elephant hunter, very much after the manner of the old alchemist, brews some concoction and, cutting the flesh of his arm, rubs in the charmed mixture ere he sets out on his adventures. This, in addition to an amulet or talisman which he wears, ensures his success in the chase, and not only do his fellows believe in the efficacy of this humbug, but he himself reposes complete confidence in it, and if he becomes a renowned hunter, others of his profession will come from hundreds of miles around to buy his medicine. Superstition, however, does not prevent his making a 'good thing' out of his secret; on the contrary, he rises to the occasion with all the astuteness and alacrity of a patent medicine vendor. It will now be clear to the reader why Sultan Mperembe asked me for medicine for killing elephants.

Leaving my tent, and desperately striving to bring my confused wits to bear on the situation, I went over to where Mperembe's men stood with my 
present of three handsome slave girls. Can the reader wonder that $I$ was in a quandary as to what to do with such a useless encumbrance? Let the bashful young man ask himself what plan he would adopt if suddenly saddled with a trio of dusky belles, and he will begin to realize my difficulty! Bootle's predicament with his baby cannot be classed in the same category: it was merely child's play.

On my approach, one of the girls told me that some four weeks previously she had been taken from a village on the Locheringo River, and that her two companions had been carried off by Mataka's people from a village near the English mission station at Unangu. She piteously begged me to keep her and

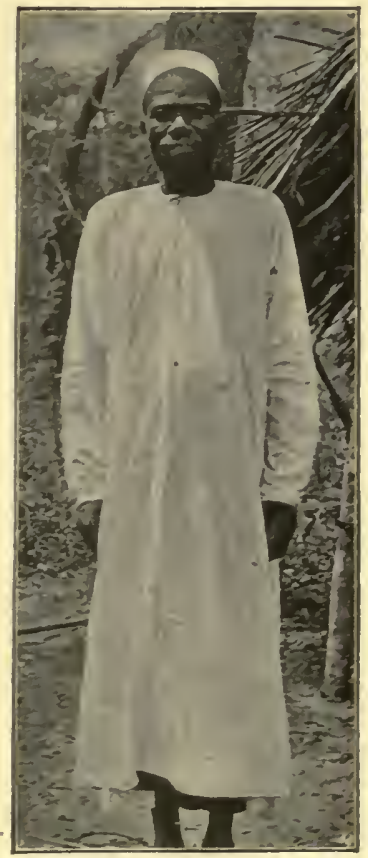

SULTAN MPEREMBE. her companions, for, if I refused, they would, she said, simply be treated as slaves and spend the rest of their lives in absolute misery. Feeling sorry for the poor creatures, I told Mperembe's men to inform their chief that I had neither gunpowder nor percus- 
sion caps, but that I could give him a specific for killing elephants, which he would find an equitable exchange for the three slave girls. The prescription was, I said, a simple one, yet, if followed out to the letter, most potent and effectual. He must, if ever he desired to be a successful elephant hunter, indulge in two cold baths per day to strengthen his heart, and as weak or unsteady nerves might mean death at any moment in the excitement of the chase, it was necessary to tone them up with a goodly consumption of tobacco, than which there was no better solace to be found. This advice, I insisted, was worth its weight in ivory, but just to show that I was by no means a skinflint, I would throw in, for luck, a bundle of blue calico and some native kangas-pieces of cloth about two square yards in size, which the native women wind round their bodies as robes.

Next day, Mperembe's men (laden with my presents to their chief) set out for their homes, and I can only conjecture that Mperembe was satisfied with his deal and the 'elephant medicine,' for not long after this incident, when I was on safari to the coast, he sent me a load of rice as an expression of his good-will.

After the departure of their guardians, I told the slave girls that they were at liberty to return to their homes should they wish to do so; but they 
replied that they entertained no such desire, for, their homes being many days distant and the journey thither through a hostile country, it was more than likely that they would be captured on the way and enslaved once more. My men's wives, too, had had a long conversation with them since their arrival and, with feminine love of matchmaking, had, no doubt, pointed out the fact that there were several eligible young men in my caravan. Moreover, I had not failed to notice the behaviour of my men, who ever since the arrival of the three girls, had been hovering round them like flies round a honey-pot, ogling them as amorous young men are wont to ogle pretty young women. Now, it chanced to be the day on which I call all my men together and give them money to purchase food, so when they were all standing in rank, I brought the girls before them and, pointing out what a fine handsome lot of fellows they were, said each might, if she wished, choose a husband from the number. As for my boys, they were one and all desirous of becoming husbands there and then, and were shouting, 'Bwana, I should like to marry this one! Bwana, I'll marry that one!' But the girls thought that the choice of a husband was a matter not to be lightly entered upon, and said they would wait a little while and live among my natives ere they selected their victims. 
Evidently the natives, though they do not formulate it, have an idea analogous with that expressed by us in the proverb: 'Marry in haste, repent at leisure.'

All three maids afterwards chose husbands from my gallant band. 


\section{CHAPTER XXXIV}

\section{A FEW DAYS' HUNTING}

After some days of promiscuous hunting, during which I had managed to get several fine heads, including sable and roan antelopes, a leopard, an eland, and one or two elephants, I arrived, one pitch-dark night, at a little village on the Luhanyando stream, and being thoroughly tired and feverish into the bargain, decided to stay there till morning. . In the middle of the night, I was awakened by a noise as if an army of dancing dervishes had invaded the village, and, on inquiring the cause of the hubbub, learned that the natives were shouting and beating drums to scare away some elephants that were having a 'night out' in the matama corn. This pandemonium failed to have any other effect than keeping me awake, and the marauders continued their feast until an hour or so before dawn, when they felt that it was advisable to depart.

At break of day, we rose, and, going into the shambas, which looked as if they had been visited 
by a tornado, picked up the spoor and started off in pursuit. At about 8 o'clock, we came up with the herd feeding in a belt of dense bush several hundred yards in width, on the banks of the Luhanyando, and hearing the crash of a breaking tree, my two trackers and I made a bee-line in the

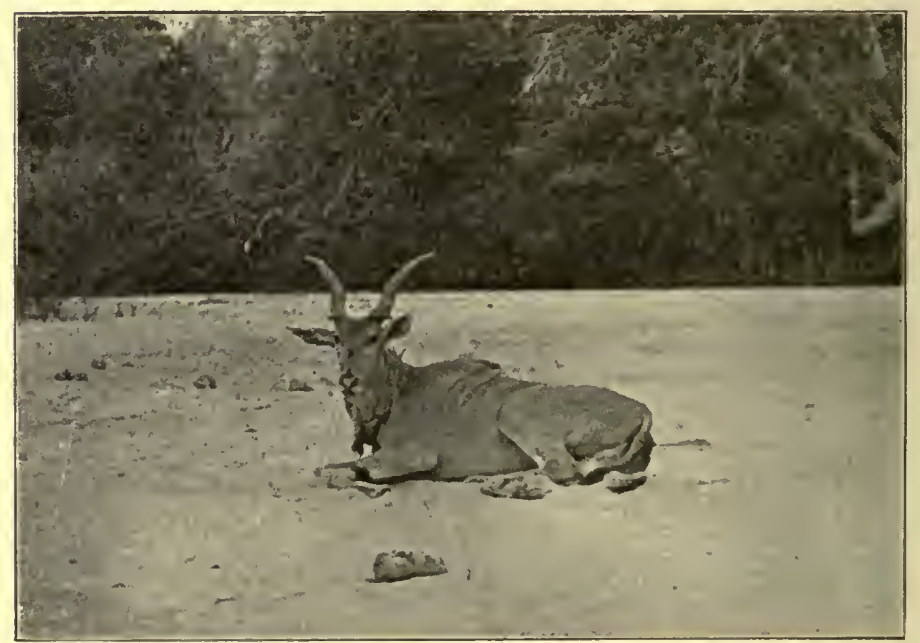

EI.A.Y.

direction of the sound. We had managed to crawl to within forty or fifty yards of our quarry, when the wind, suddenly veering, flung them our scent and sent them stampeding in all directions through the bush. Selecting the spoor of one large tusker, who had taken to a more open part of the country, we hurried along in pursuit, but he proved to be a wary old stager, up to every move of the game, 
and gave us as arduous a time of it as the most indefatigable hunter could desire. On three separate occasions, we came up with him, but he always managed to elude us and get safely away. Just as the brief, tropical twilight was approaching, we once more got in touch with him in almost

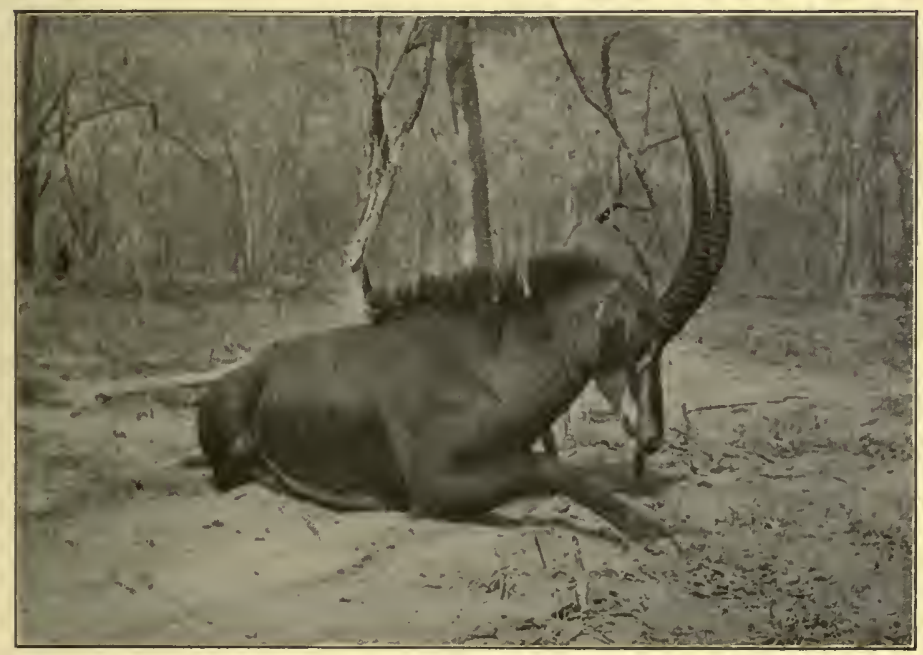

SABLE ANTELope.

impenetrable bush, above which I could only discern the tip of his trunk moving to and fro in an endeavour to wind us. As it was impossible to aim, I judged the probable location of his forehead and fired, but the bullet only sent him crashing madly through the bush, smashing up the impeding branches as if they were so much matchwood. Wearily we tramped along until night closed in 
and compelled us, dog-tired and disàppointed, to pitch camp on the spoor. That night, being too worn out either to eat or sleep, I tossed restlessly on my stretcher till dawn bade me once more start, in spite of physical reluctance, on the tracks of the wounded elephant. By ten o'clock, we found that he had joined a herd of five other males, and now there followed some solid, dogged tramping, up hill and down dale, over sand and across marsh, through thorn-scrub, and bush and long grass! Twice I stopped to give my men a mixture of sugar and cocoa to brace them up against this arduous work, while I, myself, had recourse to a most welcome Thermos flask containing hot tea. Finally, towards five o'clock, the spoor became fresher, and we could see that the elephants had begun feeding. About this time, too, the herd divided, four of them taking to the long grass, the other two making for a python- and crocodile-infested swamp, into which it would have been folly to pursue them. I decided to follow up the four, and had not made much further progress, when the noise of a breaking tree disclosed their proximity, but, as the long grass completely hid them from our view, I climbed a small tree and from this point of vantage could see them browsing on the branches and foliage of the tree they had just smashed. As it was impossible, however, to aim at a vital spot in any of them 
owing to the screening vegetation, I decided to await developments, hoping to get a better view if they came nearer, or moved further away from us. After twenty minutes of patient watchfulness up in my uncomfortable quarters, one of the four, having apparently got a whiff of our scent, began moving

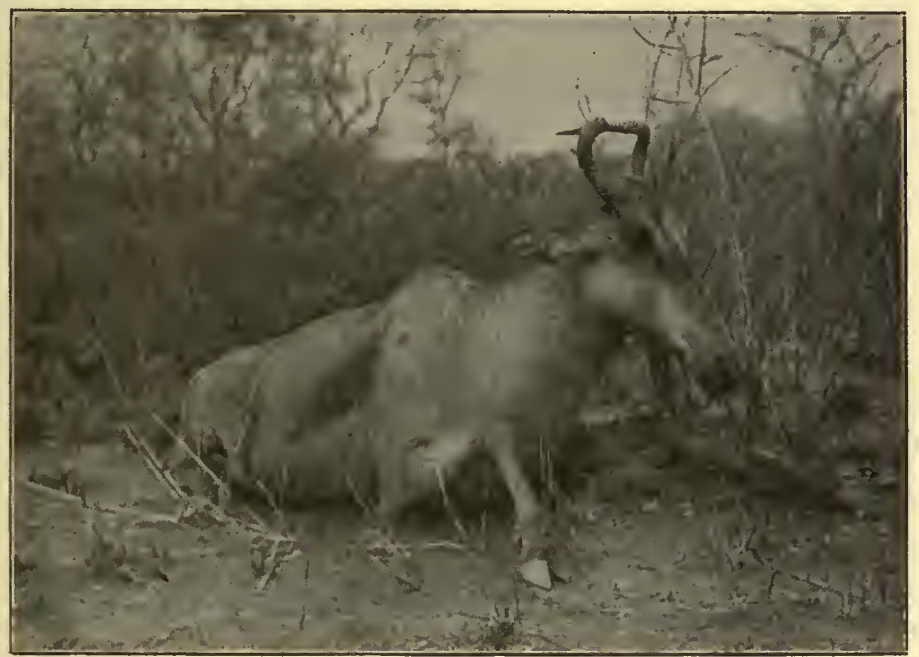

HARTEBEESTE (dicklenstein).

his proboscis about in all directions, and feeling that any further delay might prove fatal, I decided to risk a shot and trust to luck to penetrate his brain, or spine. As the tree, however, presented serious obstacles to the easy manipulation of a heavy rifle, I got my tracker to hand me up my 10.75 and, judging the position of the restive elephant's brain, as well as conditions would allow, I fired; but the 
only effect the bullet had was to bring the animal twenty yards nearer, as if curious as to the direction from which the shot had come. I could now see his head perfectly, and taking advantage of the opportunity, sent a bullet through his brain, which dropped him instantly, while his companions, seeing him fall, advanced towards him, as if puzzled as to the exact nature of his behaviour. I promptly sent a bullet through the heart of one who presented a favourable view for the shot, and, after lumbering heavily for some twenty yards through the grass, he collapsed and lay still. Scared by the second shot, the remaining animals cleared, so, quickly descending from the tree which had proved of such service, I went in pursuit, only to discover, after about another mile of tracking, that they had joined a herd of twenty or more females who were feeding. On our approach, the whole herd stampeded, clearing a path through the long grass as if a troop of cavalry had ridden by. Returning to where our prizes lay, I got my men to chop out the tusks, and as we all felt thoroughly tired, pitched camp in the vicinity. The first elephant's tusks, which were very thick, weighed 102 and $103 \frac{1}{2}$ lbs., respectively; those of the other, only $25 \mathrm{lbs}$., each.

Having heard some elephants feeding near our camp during the night, we set out at dawn on their tracks, and, as if to recompense me for the 


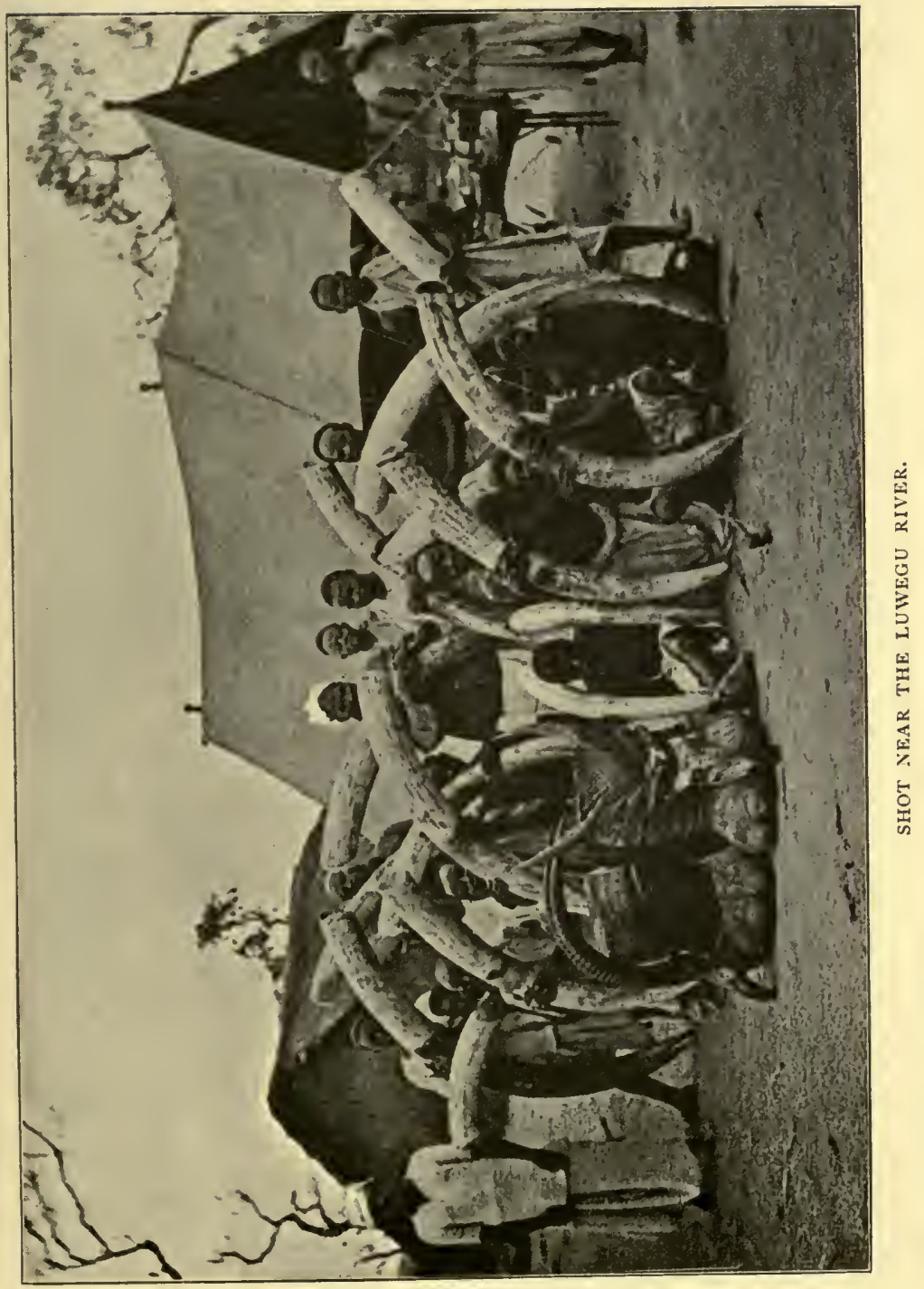


trying experiences of the previous day, after some easy going, two of them fell to a right and left from my 500 cordite rifle, while a third came down to a 303 bullet in the region of the brain. The last elephant lay on his side as if dead, and ere I could make matters doubly sure, one of the female elephants among the herd charged me furiously, my gun-bearer getting such. a fright that he bolted, carrying my 500 cordite rifle with him. I managed to send the female tearing off' with a bullet in the face, but found myself in rather an unenviable position, i.e. with an empty $\cdot 303$ rifle and only a few split bullets suitable for smaller game, but with six 500 cordite cartridges and no 500 rifle. Creeping up to the top of a neighbouring ant-hill, I yelled myself hoarse to my tracker to return with my rifle, but he had got such a fright that he never stopped running until he reached my carriers about half a mile away. To them, he was good enough to report that I had been killed, while I, very much alive, stood helplessly gazing at the wounded bull, lying spasmodically kicking his legs, a retinue of females standing round and watching his antics. After a period of ten minutes, the whole of which time he had lain on his right side, the bull gave a few desperate kicks, got to his feet, and calmly started to walk away with the females. As he was moving 
off, I put five split 303's into him without the slightest effect, and disappointed and very angry, returned to find my carriers coming to look for their dead master, my tracker following somewhat cautiously in the rear with my 500 cordite rifle. After giving him a luminous homily on the wickedness of deserting at a critical moment with his master's rifle, I severely boxed his ears, and taking the weapon from him, and accompanied by another of my men, I followed up the wounded elephant. That night, we were obliged to sleep on the spoor, but about nine o'clock, next morning, came up with the animal quietly feeding, as if nothing untoward had occurred on the previous day. As he presented a back view, I aimed a little above the root of his tail, and the bullet, crashing into his spine, brought him to his haunches. A second bullet gave him the coup de grâce. His tusks, which were of beautiful ivory, weighed 87 and 9I lbs., respectively.

During the night following the death of the above elephant, I was awakened by a yell of pain from my guide, Nepaha, sleeping some twenty or thirty yards away from me, and on rising and inquiring what had happened, found that a hyæna had bitten off his right ear. I thoroughly disinfected the wound and bandaged it up, and though poor Nepaha's looks were not enhanced by his loss, he was quite well again in about a month's time. 


\section{CHAPTER XXXV}

\section{LOVE AND FAREWELL,}

In the early months of 1906 , just after the close of the native rebellion in Angoniland, my head boy, Seremani, who had accompanied me throughout the war, advised me to go to that part of the country from which he came, assuring me that plenty of elephants were to be found there. He was of the Mwera tribe, who live near the coast in the vicinity of the Mbemcuru River.

Leaving Songea Collectorate with a caravan of about sixty people, the majority of whom were armed, because parties of rebels were still roaming about the country, we started for the coast, and after a journey of ten days or so, reached one of my old hunting grounds in the neighbourhood of the Lukumbuli stream. After spending a couple of months there in quest of elephants, we set out for Lindi on the coast, arriving at our destination some three weeks later. At Lindi, I paid off my Angoni carriers, who were anxious to return to their homes, 
and engaged coast men in their stead for a trip to the Mbemcuru River.

Now, while in Lindi, Seremani, who had, in the days gone by, quarrelled with and left his wife on

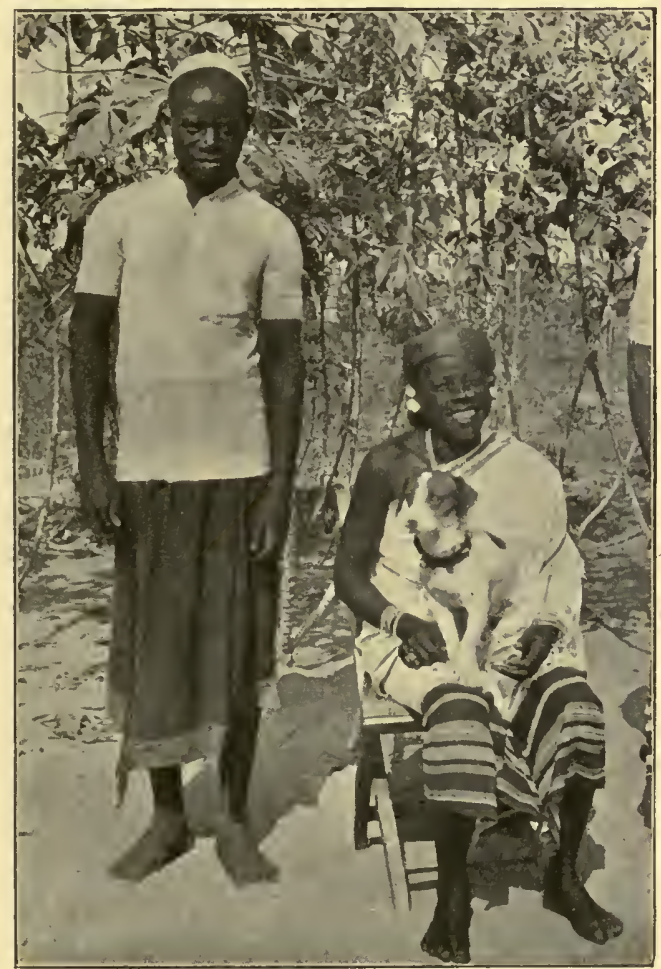

SEREMANI AND HIS LOVE, AMINA, WITH THE AUTHOR'S TERRIER.

the score of jealousy, fell under the charms of a slave girl, Amina by name-an exceptionally prepossessing African beauty. As she belonged to one of the big Arab coast traders, and a secret liaison 
with her, if discovered, would assuredly have meant imprisonment for my boy, he came to the conclusion that there was only one solution to the problem-he must redeem Amina from slavery and marry her. The question resolved itself into a question of money, generally a scarce commodity with Seremani, who was one of those rollicking, good-natured fellows, gifted with a happy knack of always looking at the laughing side of things, and who, like most good fellows, spent his money as quickly as he got it. He pondered long over the delicate subject, and, as love overcometh all things, it disclosed to him a way out of his difficulty. One day he came, with the dejected mien that only a man caught in the toils of love can assume, and laid the whole matter before me, confessing that he had spent fifty rupees in a week on his light o' love and had not a sou left, much less the price of Amina's ransom, and asking me if I would redeem her for him. I gave him the money he required, and, as soon as he possibly could, he bought Amina's freedom and married her. Fortunately, it is not given to mortals to see what is in store for them-in this little picture of life, behind the figure of Cupid, there loomed the dread shadow of Atropos.

Leaving the coast, we arrived, after a seven days' journey, at Seremani's old home, in the vicinity of which we decided to form our main camp. Thence, 
we sallied out on a hunting expedition, and had been several days absent without discovering any fresh elephant spoor, when, one morning, we chanced upon the tracks of a very large bull elephant, who had been digging up the sand at a water-hole to the depth of four or five feet, a customary proceeding with elephants when in quest of water in the dry season. We decided, there and then, to track down this animal, if possible, and as one of my trackers, who was suffering from fever, had been left behind in camp, Seremani volunteered to perform his duties. So we set forth on the spoor and, after a spell of hard tramping, succeeded in coming up with our quarry about eleven o'clock. As the wind was variable, he got a whiff of our scent, and was just about to disappear into the adjoining bush when I sent a bullet into the region of his heart, unfortunately a little too far back to arrest his career. $\mathrm{He}$ incontinently vanished and travelled so strong, that it was well nigh four o'clock before we again caught sight of him. On this occasion, he was standing still, about a hundred yards away from us, in a thicket of bamboos, and cautiously though we had advanced, he saw us and promptly charged. As he came furiously on, I drove a couple of solid bullets out of my 500 cordite into his face, but they failed to turn him, and he continued his career till well within ten 
yards of where I stood. Still keeping my eyes intently fixed on the elephant, I mechanically extended my hand for my second rifle, which Seremani was carrying, only to discover, to my intense dismay, that my boy, instead of following me like my shadow, had fallen a few yards behind. It was now too late for him to reach me, so resigning myself to the fate which I was always ready to meet, I stood absolutely still, feeling that my only chance of escape lay in not attracting the animal's attention by the slightest movement. Seremani, a few yards behind me, also cognizant of the fact that any hope of safety lay in perfect immobility, strove for a few seconds to face the situation, but the terrifying spectacle of the huge beast, standing so close and staring at us with blood streaming down his face, unnerved the poor fellow and he dashed wildly to the rear into a clump of bamboos. That action saved my life, for, like a flash, the elephant rushed past me and after Seremani, and ere my boy had gone many yards, and before I could reload and fire, the animal overtook him, thrust his tusk through the poor fellow's thigh and knelt on his chest. It is hardly possible for anyone to realize how swiftly this awful drama had taken place, but some idea may be formed of the celerity of the action when it is remembered that it was completed before I could eject my empty cartridge and reload. Raising my 
rifle, I drove a bullet into the elephant's skull, a little behind his ear, sending him reeling away from my boy, and reloading with utmost speed, I reached his brain with my next shot, dropping him not more than six yards away from the body of his victim. At once, I rushed to Seremani's side, but, on seeing the shocking injuries he had received, knew it would only be a matter of moments ere he was done with all earthly things. I hastily applied a water-bottle to his lips, but he was too far gone to drink, and catching hold of my hand, managed to mutter feebly :

'Quhaeri, bwana, wango, nimi gufa lao!' (Good-bye, my master, to-day I shall be dead).

His brother, Pombe, coming up at this moment to where he lay, Seremani recognized him and muttered his last words: 'Quhaeri, Pombe.' Then, looking into my eyes and still gripping my hand, he. passed away.

We carried the remains of my poor boy for two days, and when within an hour's journey of his home, laid him to rest in the glorious burial-ground of the free, wild, forest.

Shortly after this unhappy event, I left the district, and so grieved was I over the death of my boy (he is the only servant that I have had killed in all my hunting expeditions), that I could not bear to continue hunting in that locality. 
This elephant, whose tusks weighed 99 and $105 \frac{1}{2} \mathrm{lbs}$., proved to be well known to the natives of the district, owing to one of the toes of his right foot being much larger than the others, and hence they had given him the name of 'Cherunda.' During the few years previous to the death of my boy, Cherunda had managed to account for several native hunters. 


\section{CHAPTER XXXVI}

\section{THE HUNTER'S END}

There are so many risks, as well as privations, incidental to the life of an elephant hunter, that he has only to keep at the game long enough to meet with an untimely end, and that, as a rule, a violent one. Even should he survive the many dangers attendant on the calling, in the long run, he generally undermines his constitution and lives on a mere wreck of his former self. Still, while the life lasts, it is one of the most glorious and exhilarating on earth, for again and again the chase resolves itself into an exciting duel 'twixt man and beast, and though the chances, even in dense jungle, are in favour of the man, occasions frequently arise when the latter's life trembles in the balance. The hunter knows absolutely that if his rifle or cunning fails him in the least, he is as good as dead, and it is on this simple understanding that he joyfully sets out. The three little episodes which follow, will, I think, give the reader a glimpse into the tragic side of a 
life devoted to the chase, a side upon which a hunter seldom lets his mind dwell, but to omit which would be to state only one half of my case.

\section{I}

A few years ago, an old friend of mine, Goddard by name, and one of the best of fellows, was killed by an elephant in North Eastern Rhodesia. Goddard was by no means an amateur at hunting-on the contrary, he was exceptionally cool, an excellent shot, and had accounted in his time for a considerable number of elephants.

It appears that one evening he set out in search of small game, taking with him a 303 rifle only, and, judging from subsequent events, must have come upon an elephant quite unexpectedly and been tempted by the prospect of a pair of heavy tusks to follow the animal into a patch of dense bush. His bearers, having waited a considerable time for him and finding that their master did not return, decided to follow his tracks into the thicket, but had not gone far before they discovered Goddard's dead body shockingly trampled and with a gaping wound in the chest where a tusk had been driven clean through. Beyond the fact that he was killed by an elephant, the exact manner in which Goddard came to his end is unknown. The sad event may have 
occurred in many ways, and I can only offer a few alternative suggestions in an endeavour to throw some light on the affair. Goddard's rille may have hung fire, owing to a defect in the cap of the cartridge (a mischance which has occurred on two or three occasions to myself, even when face to face with a charging elephant), or he may have fired at the animal and failed to place the bullet in a vital spot, the brute at once turning on him and killing him. Again, the elephant may have hidden silently in cover waiting for him, as elephants very often do when pursued, and, when Goddard was only a few paces distant, rushed out and taken him unawares. Lastly, there is a possibility that in his excitement he may have forgotten to reload his rifle.

\section{I}

A few years ago, a German, named Ringler, met with a violent end while hunting elephant in the Mbwehu bush, Kilwa district. Some two months afterwards, when in the same neighbourhood, I enlisted the services of the identical tracker that Ringler had engaged, and from him I secured an account of how the hunter had come by his death. He told me that Ringler, one day, wounded an elephant, and, on the day following, while tramping through the forest, suddenly came across an elephant. 
lying down. Ringler's men warned him that the animal might only be sleeping, and advised him to eliminate all possibility of a mishap by putting a bullet into the beast, but the hunter, confident that the animal was dead and the identical one that he had wounded on the previous day, went up to the recumbent monster and, encircling one of the tusks with his fingers, exclaimed: 'What glorious ivory!' Like a flash, the elephant, who was only dozing, caught him with his trunk and smashing him with his tusk, killed him on the spot.

\section{I I}

Somewhere, deep in the forest, between Lake Nyassa and the sea, probably in the vicinity of the Locheringo River, there lies buried an Englishman of the name of Watkinson. Exactly where, no white man knows. Possibly some natives do, but there are some things which black men do not tell, and this is one of them.

In 1903, Watkinson, accompanied by ten carriers, two boys and a gun-bearer, left the lake with the intention of following the Rovuma River down to the sea, shooting as he went, and hoping to reach the coast with a goodly stock of ivory. The boys and gun-bearer had been in his service for years; the carriers were only raw natives engaged for the 
trip. As it was the rainy season, and an exceptionally wet one at that, his friends at the Lake advised him to postpone his safari until the rains had ceased, but Watkinson was not to be persuaded, and so went forth on his last shoot.

Four months later, three diseased and emaciated men arrived at the Lake: they were Watkinson's two boys and gun-bearer. Depending for food on what they could kill, and covered with sores owing to the privations they had suffered, they had made their way through a hostile country and at length managed to reach Matengula, bringing back in safety their master's guns, a few personal belongings, and his diary. In the diary was a portrait of his mother.

After leaving the Lake shore, Watkinson and his party had travelled for some ten days through an uninhabited and foodless forest between the Msinjie and Lujenda Rivers, where, at the time, I had been hunting for about two years, and, during this portion of his journey, his carriers had basely deserted, leaving him and his two companions to fare as best they could. Having put all the loads that they were unable to carry, up in trees, where they would be secure from the attentions of wild animals, they had plodded slowly on. Judging from the painfully brief entries in his diary, Watkinson was now in a very weak 
state, suffering from constant fever, yet tramping day after day through long grass, wading through water and marshes, night after night sleeping in wet clothes, and never a blink of sunshine during the whole time to enable him to dry his kit. The very small quantities of flour, tea, and sugar which he had been able to take with him when his carriers had bolted, now ran out, and as sores had broken out in his mouth and throat, he was incapable of eating meat, which was the only food procurable. When he was absolutely. unable to proceed any further, his boys built him a small grass shelter, under which he lay, hoping in a short time to regain strength enough to reach some village where food such as fowls, eggs, and vegetables might be obtained. It was here that a strange tragedy was enacted. One day, when his boys were preparing the roots of a wild plant, called acca, which they had found in the forest, and which are poisonous till cooked to shreds with several changes of water, something after the manner of tapioca, Watkinson, by this time delirious with sickness, suddenly emerged from his shelter, and seeing the pot steaming over the fire, proceeded to help himself to some of the deadly contents. Only one boy was present at the time, and he, warning his master that the poison had not been eliminated, strove to dissuade him from partaking of the baneful roots; but Watkin- 
son, with the obduracy of dementia, insisted that if a native could eat it, he himself could eat it also. That night the end came, and he passed away in great agony, accusing his boys to the last of having deliberately poisoned him and, next day, those staunch fellows, who had stuck faithfully to him till death, buried his body and placed stones over the grave to prevent hyænas disturbing his remains.

The last entry in his diary reads :- Feel like dying, but must get right. Nothing to eat for seven days. Elephant here if only I could get after them.'

Could any words be more vividly characteristic of a hunter, or so full of poignant tragedy as that last sentence of Watkinson's - 'Elephant here, if only I could get after them!' Poor fellow, he was game to the last! Can any man wish to be more when the 'Angel with the darker draught' draws nigh? 


\section{APPENDIX A.}

Creepers from which water can be obtained in the dry season in East African forests.

LETUKU (Mwera language).-The tuber of this creeper is found about a foot beneath the surface of the soil, and resembles a turnip in size and colour. The tuber is full of a cool, watery fluid.

NAmumbu (Mwera language).-Is a large tree with a silver-grey bark. The natives dig down to the roots and, by cutting them, obtain an almost tasteless fluid, which forms an excellent substitute for water.

NTAMBA.-A creeper found in many parts of the forest, and sometimes equalling a man's arm in thickness. The stems, when cut in lengths of about two feet, exude a beautifully fresh, almost tasteless water.

MPUPULU (Mwera language).-A creeper, resembling the Ntambo, but found only in bush country.

TANDANDUMBIE (Mwera language). - A creeper found only on the banks of streams. Its stems supply a fairly palatable liquid.

\section{APPENDIX B.}

\section{Wild Fruits.}

I. Mbinjie.-A large bush, producing a kind of wild almond. The fruit is oblong, of the size of a pigeon's egg, and of a beautiful, reddish colour. The pulp has a bitter sweet flavour and encloses a large stone, which encases the almond. 
2. MBURA.-A splendid tree, with magnificent branches, bearing a round fruit, which attains the size of a golfball. The colour of the fruit is brownish golden; its fiavour resembles dates, but with a suspicion of bitterness. Elephants are extremely fond of this fruit. The natives gather them in large quantities, and pound them up to extract the stones. The pulp is kneaded with flour and made into cakes.

3. HAEKAERA.-A large tree, bearing clusters of a light golden fruit, which is about the size of a hen's egg. The fruit is oblong in shape, contains three seeds, and has a delightful odour.

4. KooseE.-This fruit, borne on a large tree, is the size of a pigeon's egg, and has one large stone. The skin is very thick and of a reddish brown tint. The tree is found in great numbers in Angoniland.

5. Matonga.-A greenish fruit, the size of an apple found on small trees. The inside is filled with large seeds imbedded in a fleshy pulp. The taste is bittersweet, and I have found the fruit an excellent thirst quencher. Buffaloes and elephants are extremely fond of it.

6. Maveero.-A small, yellowish fruit, about the size of a gooseberry, found on low trees. The taste is peculiar. My men are continually chewing them when tramping through the forest. The pulp is scanty and encloses three pips.

7. Masuko.-A tree, producing a fruit about the size of a plum. The colour of the fruit is dark red. The flesh resembles an apple in flavour and contains a few large seeds. The natives are extremely fond of it. All game such as lions, leopards, wild pigs, warthogs, and wild dogs are partial to the Masuko. My wild dog, Jumbo, used to eat them with avidity. I have repeatedly found the spoor of lions and leopards around 
these trees and unmistakable evidence of their having consumed the fallen fruit.

8. MatabeanNiE.-A small tree, found near streams, and in valleys; it bears a round fruit about $I$ inch in diameter and of a yellowish green colour. The fruit is very soft and juicy, and contains one seed, about $\frac{1}{2}$ inch in diameter.

9. Mlola.-A large tree, bearing a fruit similar to that found on the Undendie shrub, an account of which follows. The whole of the Mlola fruit is eaten-skin and all.

Iо. MBuiE.-A very large tree, sometimes of tremendous girth, with fruit as large as cocoa-nuts. Elephants are particularly fond of these fruits, and shake them down from the trees. The fruit, which is enclosed in shell thinner than that of the cocoa-nut, is of a pale green shade, is full of seeds, and tastes something like a lime sweetened.

I I. MSARA. - A fruit, something similar to the Matonga but smaller and sweeter. Its flavour is rather nice, and something akin to a sweet lemon.

I2. NDAVA.-A large bush, bearing a chocolate-coloured fruit, something larger than a cherry, but full of little seeds. I have eaten a great deal of this fruit, and think they would be delicious if cultivated. Elephants are very partial to them.

I3. Nyonio.-A magnificent tree, with wide-spreading branches, which bears a slightly oblong, chocolatecoloured fruit, about the size of a cherry, in clusters of three and four. The fruit is borne in profusion, and would, I believe, repay cultivation.

I4. Pitimbie.-A large tree, bearing tremendous quantities of a cherry-sized fruit. This fruit is also borne in clusters, but has only one seed, and is bitter-sweet in flavour. When ripe, the skin is black. 
15. SabutaniE.-A large tree, bearing fruit of a bright red colour and about the size of large gooseberries. The pulpy flesh surrounding the one or two seeds, is of a bitter-sweet flavour.

I6 TOPIE-TOPIE.-A small tree with wide-spreading branches, bearing a profusion of light green fruits containing several back seeds. The fruit is about two inches in diameter, and the natives eat the whole of it, except the seeds.

I7. UNDENDIE. - A small shrub, about two feet in height bears clusters of reddish fruit (about the size of raisins) with small seeds like the gooseberry. My cook often used to prepare them for me, and they make excellent eating. The natives eat the whole fruit skin and all.

\section{APPENDIX C.}

NGEKHE.-A small shrub, from which the natives procure a remedy for dysentery. The inner bark is boiled and the concoction drunk, and in a day or two the sufferer begins to recover.

TANGALERO.-A creeper that bears a kind of vegetable marrow, which is somewhat larger than a Jaffa orange, and of a mottled green colour. The natives use the pulp as a substitute for soap in washing their clothes. The seeds inside, after being dried, are fried and eaten.

MAUNGO.-The roots of this tree give off a most objectionable odour, and the natives most emphatically assert that if some of the roots are placed in a house no snakes will enter. They tie strands of it round their ankles while hunting in the forest for honey, to safeguard themselves against being bitten by snakes. 


\section{APPENDIX D.}

LINYANYANBUIE.-A caterpillar, which attains a length of two or three inches and is covered with long brown spiky hairs. If the caterpillar be brushed off the arm, neck, etc., some of the hairs penetrate the skin and set up an intolerable itching for several hours. The natives have a most expert, though cruel, method of getting rid of these unwelcome caterpillars. The caterpillar is touched with a hot iron, round which it promptly curls without leaving behind any of its obnoxious hairs.

KASHATA.-Another caterpillar, which, if it gets on the skin, causes considerable pain for hours-but no itching. 


\section{INDEX}

AbDullah NKWANda, 177

Acca, a plant, 280,314

Ahellas (Hades), 67

Amateng tribe, 278

Amina, a slave girl, 303, 304

Angoni, a tribe, 140, I4I, I44, 145, $146,222,245,246,279,281,302$

Ants (njeremba), 278

Antelope, 295

Asalie, a maiden, $83,84,85$

Asari, honey, 279

Askari, native policeman or soldier, $75,116,179,204$

Atonga tribe, 278

Awembe Mountains, I76, 207

I3ANgALla River, 79, IO9, I62, 258

Baramaeri, a carrier, I IO, I I I

Batley (R.), I I 8

Beira, a town, ${ }_{3} 8$

Ihhangi, a kind of tolacco, I79

Binguni (Paradise), 67

Bissari, a vegetable, 278

Blantyre Dog Show, 249

Boma, a fort, I 16, I17, 179, 203

Brandy, a terrier, 249 et seq.

British East Africa, I66

British Nyassaland, I 6

Buffalo fiesh, 277

Bushbuck flesh, 277

Cinacunda, a tribe, 227

Chameleon, an animal, 2 I 5

Chepungu bean, 28 I

Cheringulabunda, a snake, 145

Cherunda, an elephant, 308

Cherungir, a shrub, 146

Chillies, a vegetable, 278

Chimbunga, a chief, 140,142

Chingendo, a tracker, i $8,88,89,90$, 9I, 103

Chingomangie's village, 248
Chingwaengie, honey, 279

Chiperzeri, a stream, 86

Chokoma, a hunter, 227

Combe (Strophanthus), a shrub, 246

Congo State, I 66

Crocodile's eggs, 279

Dемво, a boy, I6

Diabolo, the game, I95

Dichlenstein (hartebeeste), an animal, 297

Dietary and hygiene, I67 $\mathrm{ct}$ seq.

Dog-flesh, 278

Dilguwaloh, or black mamba, a snake, I 46

ELAND, an animal, 277, 294

Elephants, eyesight of, 95, 96 at rest, 160 et seq

FIPA COUNTRY, 233

Fundi Bakali, a hunter, 226, 227

Fundi Juma, the elephant hunter, 40

German EAST AFrica, il 8, 157,166 , 246,287

Goddard, Mr., 310

Golambepo hills, 59, 6I, 65, 207, 209, 2 I I

Gulalahie, a snake, I44

Gwia, a chief, 78

HAEKAERA, a fruit, $3 \mathbf{I}$

Hamice, a man, 240, 24I, 242

Hanguy, a root, 280

Hartebeeste (dichlenstein), an animal, 238,297

Henderson, Mr., 286

Hippopotamus, 277

Honey (asari), 279

Hongo, a hunter, 227 
Hygiene and dietary, 107

Hyiah, a tracker, 78, 79, 151-I55, I $84,230,231$

\section{INCUNIA TREE, 277}

Insoma, honey, 279

Inswala flesh, 277

Iperi tonga, a snake, I 45

Iperie, a chieftain, 42,44

\section{JOHNSTON-FORT, 282}

Jokomahamba (green namba), 146, 216 , 217

KaliaLlikamoscilie, a grass, 281

Kanga, a woman's dress, 200, 290

Kapopo, a tracker, 67

Karanji, a chief, 258, 27 I

Kashata, a caterpillar, 320

Kibali Hill, 109, 259

Kiliva district, 3 I I

Kis-umbi (or Walinganiro), a chief, I 7, I 18

Kisumba, a town, II8

Kitanda, a bed, 2 Iо

Kitulika stream, I $8_{3}$

Kolapongu, a snake, 144

Kom Kom (an elephant), ch. XIV

Konyaki, a boy, I 54, I 55

Koodoo, an animal, I4ó

Koosee, a fruit, 3 I 7

LEANDUKU (Sultan), 32, 77, 228

Lebomah, a snake, I4I

Lecama, honey, 279

Lehombero River, 4 I

Leoto, water-hole, Ioo

Lepalie, honey, 280

Lependura, honey, 280

Lepinganombie, a snake, I4I

Lepunganonie, a tree, 245

Lerongie jungle, 42, 44

Lequania, bean, 28I

Letaebo (black mambu), a snake, 140

Letaegaera, a shrub, 246

Letuka, a creeper, 316

Limbo, water-hole, IoI

Lindi, a town, 222, 302, 303

Linyanyanbuie, a caterpillar, 320

Liwale, a town, 203

Locheringo River, 57, 65, 289, 31 2

Locusts, 279

Luhanyando stream, 70, 293, 294

Lujenda River, I 16, I I8, iso, 287
Lukumbuli stream, $83,235,302$

Lumasuli River, 143, 2 16, 218,258

Luwegu River, 32, 41, 70, 93. 94, I 12, 228

MACUA TRIBE, $25^{8}, 27^{8}$

Mahenge, district, 222

Mahometanism, ch. xxix

Majamanda, a luasket, 84, I42

Majavie, a demon, II5

Majemba, a tracker, 78,79

Makabuli, an elephant hunter, 218, $219,220,22$ I

Makakora, a hunter, $25^{8}, 262,26 \hat{\jmath}$, 271,272

Makanjira, a chief, 117

Makanyanga, a head-tracker, $6 \mathbf{5}$

Malinganiro (or Kisombi), a chief, II7, II 8 , ch. Xvir, 176

Malingum, a tracker, I51, I 56, 224, $225,228-234,260,266,268-271$

Mamba, black and green snakes, 146

Manganga, a shrub, 245

Mangu, a tree, 30

Manjora, a tracker, I I 2, 240-242

Marseilles, 3

Maschilla, a hammock, 37, 79, 223 . $263,269,270$

Masuko, a fruit, 3 I 7

Matabeànnie, a fruit, 3 I 8

Mataka, a chief, 57,60,61, 117, I18, 176,289

Matama, corn, 44, 81, 202, 293

Matergula, a Portuguese Collectorate, I 8, I $76,177,178,313$

Matomoro, a tracker, 2.5

Matonga, a fruit, 317

Matuku, a potato, $28 \mathrm{I}$

Maungo, a tree, 319

Maveero, a fruit, 317

Mbarangandu, a river, $87,88,124$, 125,183

Mbemcuru River, I7, 30, 86, 140, 302, 303

Mbinjie, a fruit, 316

Mbuie, a fruit, 3 I8

Mbura, a fruit, 317

Mbwehu bush, 3 I I

Iculoe, a snake, I46

Medicine-man, 53

Melanji, a chief, i IS

Mepania, a potato, 28I

Mewalie, a stream, II 2

Mhega, a district, 246

Midgets, 279

Mlinda, a grass, $28 \mathrm{I}$

Mlœravana, a tree, 54 
Mlola, a fruit, 313

Monkey-nut, 54

Moslemisn, 205

Mpcrembe (Sultan), 287, 288, 289, 290

Mpimbi, a town, 282, 286

Mpupulu, a creeper, 316

Mputa, a man, 240, 242

Msara, a fruit, 318

Msindaeka, a herb, 28r

Msingie river, $65,209,212$

Mungo, a tree, 277

Mwavie, a tree, 265

Nwera, a tribe, 140, 141, 144, I45, $146,272,278,281,302$

Myaeah Mountains, 216

Nagoromenia's KraAl, 42

Najika, a snake, I44

Nakahungu, a snake, 142, I43

Namabamba or green namba -a snake, I 46

Namaraswe, a snake, 140

Nambaco, a snake, I40

Namumbu, a creeper, 316

Naru, a snake, I 44

Nculie, a snake, I 46

Ndava, a fruit, 318

Nepaka, a guide, 301

Ngekhe, a shrub, 319

Njenjie River, I05

Njeremba, an ant, 278

Njerembo, a tracker, $83,84,85$

Nlunkwae Hill, 222

North Eastern Rhodesia, 310

Nquangwa, a tree, 45

Ntamba, a creeper, 29, 316

Ntawasie, a tracker, 49, I03, 106, 107, IOS, 1 28, 132, 134, 1 $84,224,225$, 256,267

Nyama, meat, 274

Nyassa (Lake), 75, I 16, I 1 7, 118,176 , $207,245,246,248,278,279$, 312

Nyassaland, 282

Nyonia, a fruit, 3 I 8

Palaver (Shauri), 59

Pitimbie, a fruit, 3 IS

+ Poisoning, ch. Xxvir.

I'ombe, native beer, 14, 53, 205, 220, 242

Ponbe, a boy, 307

Porcupine flesh, 278

Poria forest, 3, 15, 69, 120, 1 39, I44, I $82,210,259$
Portuguese East Africa, I16, I 18, I 58 , I 66,287

Potosambo, a headsman, 222

Puff-adder, 1 39, 145, 21 5, 268, 270, 278

Python, 278

QUAJU, a tamarind tree,' I 8

RaID, The, ch. XII.

Reedbuck flesh, 277

+ Religion, 205, ch. Xxix.

Rhinoceros flesh, 277

Rifles, 170 et seq.

Ringler (Herr), 3I I

Rovuma River, 57, 78, 116, 118, 161, $236,258,287,312,313$

Rufiji River, 228

Ruka-ruka, a force of soldiers, 117 , 210

Sabutanie, a fruit, 319

Safari, 85, I I I, 124, 169, 218

Seremani, head boy, 302, 307

Shamba, a garden, $44,81,82,112,142$, 196, 202, 228, 229, 293

Shauri, a palaver, 59

Shenzi, heathen, 59, 67, 180, 205

Shire River, 80, 11 $8,282,286$

Simba, a tracker, $16,18,19,20,21,24$, $25,26,28,29,30,33,34,45,47$, $49,71,72,73,94,98, I_{1} 3,114$, I I $5,126,128,129,130,132,134$, $136,140,143,205,217,235,260$

Snakes, ch. XIV.

Snuff, 20

Soheri tribe, 278

Songea collectorate, $78,222,302$

Songwe, a snake, 143

Strophanthus (combe) a shrub, 246

Sutherland (James), Report of death, 40

Swasuri, a maid, 6o, 64

TAMARIND TREE (quaju), IS

Tandandumbrie, a crecper, 316

Tangalcro, a creeper, 319

Tanganyika (Lake), 233, 245

Timbaweesi, a grass, 28I

Tombacco (an elephant), 85 et seq.

Topie-topie, a fruit, 319

Tse-tse fly, 167,252

Tumbie-tumbie tree, 277

Tumbo, a boy, 37, 54

Twcegah, a tracker, 62, I 32

UBENA TRIBE, 278

Ufuta, oil, .199 


\section{Uganda, I66}

Ujungu tree, 243, 246

Ulalu, a snake, 144

Unangu, a village, $66,118,289$

Undendie, a fruit, 319

University Mission, II 8

Upanga tribe, 278

Upupu, itching bufalo bean, 46, 125, 281

Usufu, a boy, 134, 135, 136, I5 I, I56, 209, 286

Usufu (not the boy), 240

Uwanjah, a snake, I45
WANGINDO COUNTRY, 246, 254, 257, 278

Wangoni, a tribe, 42

Watkinson (Mr.), 312-315

Westley-Richards bullet, I 72, 174

Whiskey, the terrier, 182

Wild dogs, Ch. xxvı.

Wyao tribe, 117, 176, I 79, 2SI, 287

YAn, $5^{8}$

ZAMBESI RIVER, I 3 S 


\section{A SELECTION OF NEW BOOKS.}

NARRATIVE OF THE VISIT TO INDIA OF THEIR MAJESTIES KING GEORGE V. AND QUEEN MARY AND OF THE CORONATION DURBAR HELD AT DELHI, 12th DECEMBER, 1911. By the Hon. John Fortescue. With 32 Illustrations. 8vo, ros. $6 d$. net.

*** This work constitutes the official record of the Visit and Durbar.

SOUTH AIIERICA : Observations and Impressions. By The Right Hon. James Bryce, O.M. IVith Maps. 8vo, 8s. 6d. net.

CORRESPONDENCE BETWEEN LORD ELGIN AND LORD GREY ON THE AFFAIRS OF CANADA. Edited by Arthur G. Doughty, C.M.G., Litt.D., and ADam ShortT, C.M.G. 8 vo.

FROM POLE TO POLE. A Book for Young People. By Dr. Sven Hedin. With Jllustrations and Maps. Extra crown 8vo, 7s. 6d. net.

A COLONY IN THE MAKING; or, Sport and Profit in British East Africa. By LORD CRANworth. With Map and Illustrations. 8vo, I $2 s$. net.

A TRAMP'S SKETChes. By Stephen Graham, Author of "Undiscovered Russia." With Frontispiece. Extra crown 8 vo, 5 s. net.

\section{HIGHWAYS AND BYWAYS IN SOMERSET.}

By Edivard Hutton. Illustrated by Nelly Erichsen. Extra crown 8vo, 5s. net. [Highways and Byzoys Series.

THE PAGAN TRIBES OF BORNEO. A Description of their Physical, Moral and Intellectual Condition, with some Discussion of their Ethnic Relations. By Charles Hose, Sc.D., and William McDougall, M B., F.R.S. With Four Illustrations in Colour, over 200 fullpage Collotypes and many Illustrations in the text. Two vols. 8vo.

THE LUSHEI KUKI CLANS. By Lieut.-Colonel J. Shakespear, C.I.E., D.S:O. With Four Plates in Colour and other Illustrations and a Map. 8vo, ros, net.

LONDON: MACMILLAN AND CO., LTD. 


\section{A SELECTION OF WORKS ON SPORT AND 'TRAVEL.}

THE MAN-EATERS OF TSAVO, and other East African Adventures. By Lieut.-Colonel J. H. PATterson, I).S.O. Illustrated. IVith a Foreword by Frederick Courteney Selous. 8vo, 7s. 6d. net. Cheap Edition. Globe 8vo, is. net.

IN THE GRIP OF THE NYIKA. Further Adventures in British East Africa. By Lieut.-Colonel J. H. Patterson, D.S.O. Illustrated. 8vo, 7s. $6 d$. net.

A HUNTER'S WANDERINGS IN AFRICA. Nine Years amongst the Game of the Far Interior of South Africa. By Frederick Courteney Selous. Illustrated. Fifth Edition. Extra Crown 8vo, 7s. 6d. net.

\section{AFRICAN NATURE NOTES AND REMINI-} SCENCES. By Frederick Courteney Selous. With a Foreword by THEODORE ROOSEvelt and Illustrations by E. Caldwell. 8vo, ros. net.

\section{SPORT ON THE NILGIRIS AND IN WYNAAD.} By F. W. F. Fletcher. Illustrated. 8vo, r $2 s$, net.

NOTES ON SPORT AND TRAVEL. By GEORgE KingsLey. With Introductory Memoir by his Daughter, Mary H. Kingsley. Extra Crown 8vo, 8s. 6d. net.

TRANS-HIMALAYA: Discoveries and Adventures in Tibet. By Sven Hedin. With 388 Illustrations and Io maps. Two vols. 8vo, 3 os, net.

OVERLAND TO INDIA. By Sven Hedin. With 308 Illustrations and 2 Maps. Two vols. 8vo, 3os. net.

ACROSS AUSTRALia. By Baldwin Spencer, C.M.G., F.R.S., and F. J. Gilles. Illustrated. Two vols. $8 \mathrm{vo}, 2$ Is. net.

THE LAND OF UZ. By Abdullah MansûR (G. Wyman Bury). Illustrated. 8vo, 8s. 6d. net. LONDON : MACMILLAN AND CO., LTD. 


\section{|||||||||||||||||||||||||||||}

r

UC SOUTHERN REGIONAL LIBRARY FACIUTY

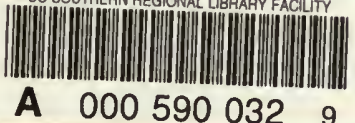

A 0005900329 
